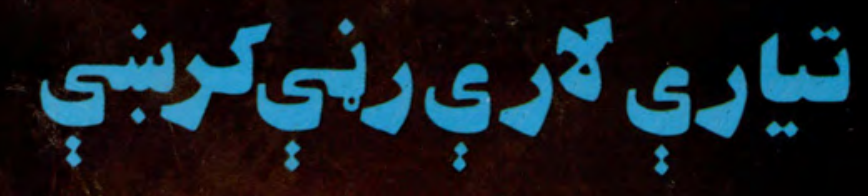

الحاج نكيال 


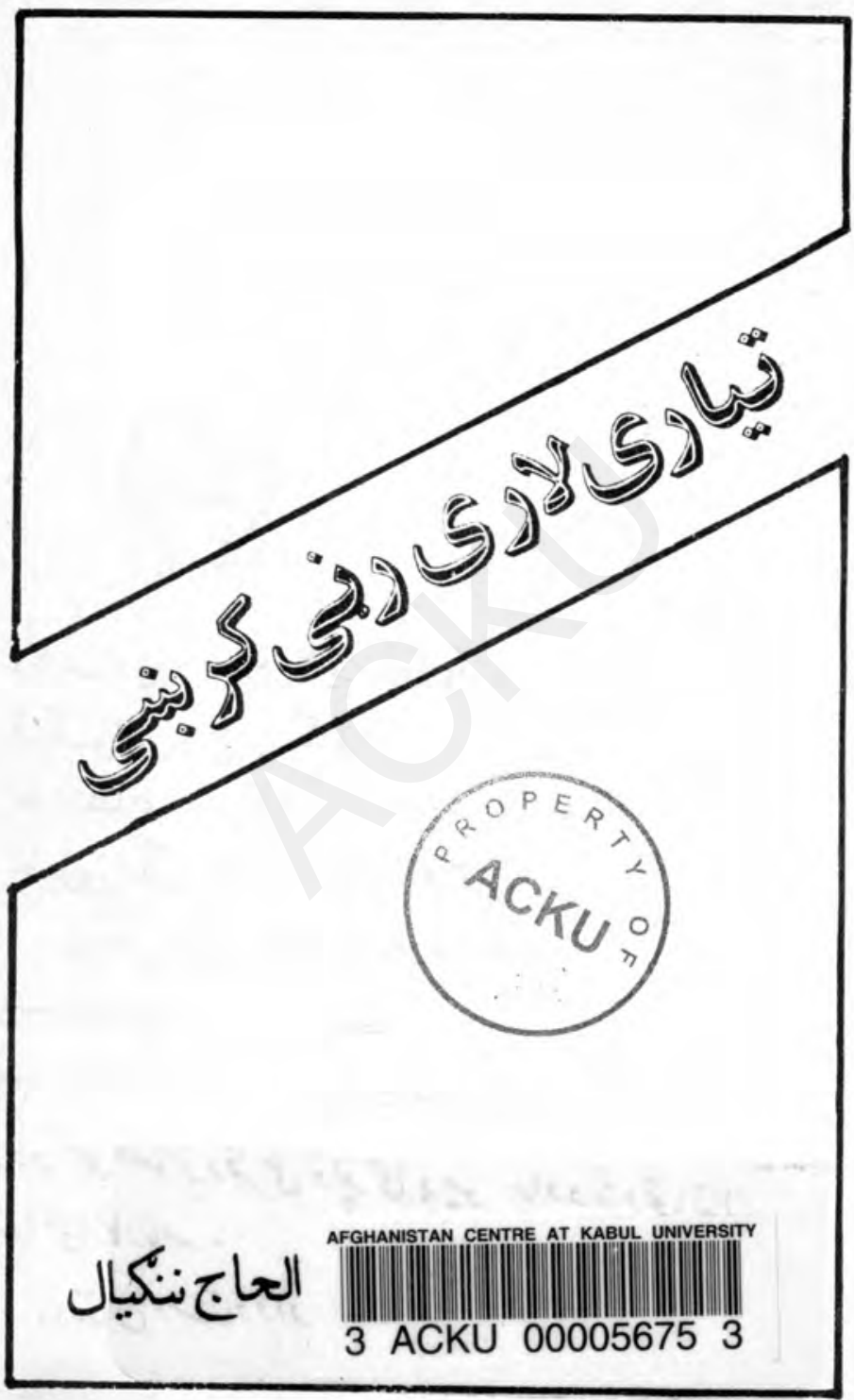




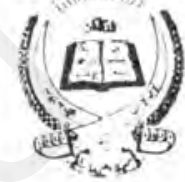

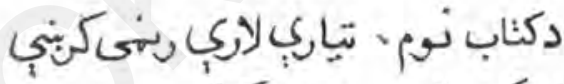
لبكــوال : ع نــكال

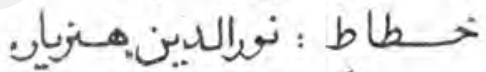

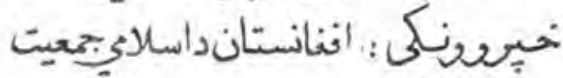

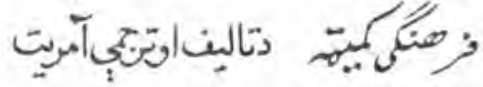

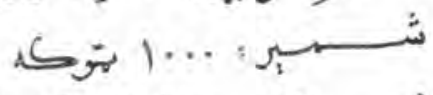

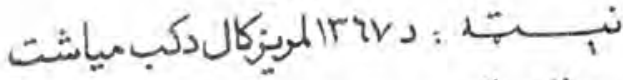

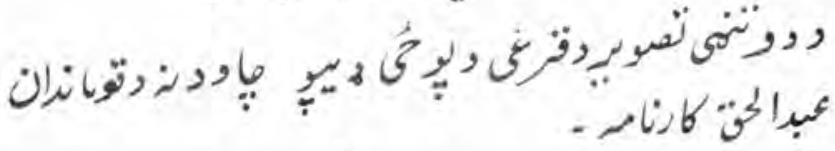

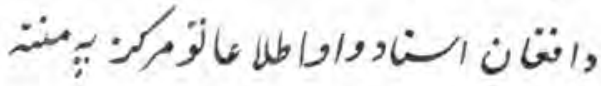



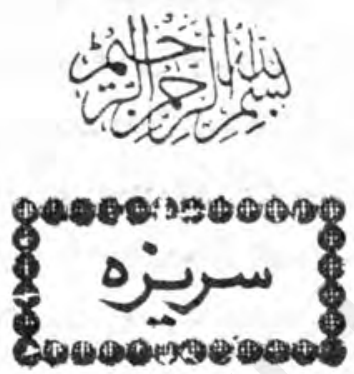

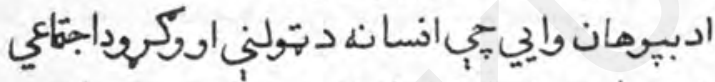

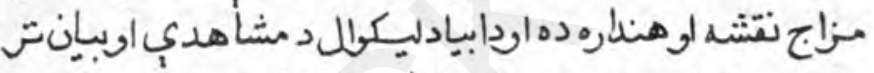

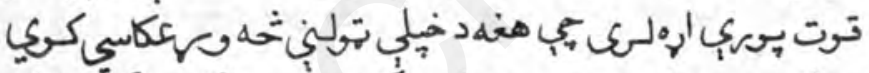

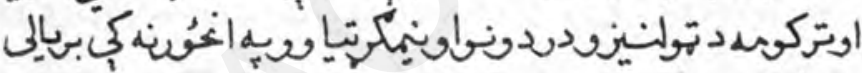

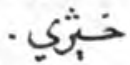

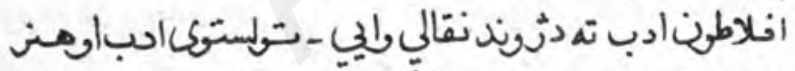

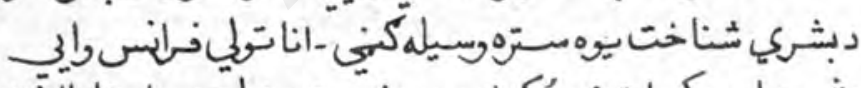

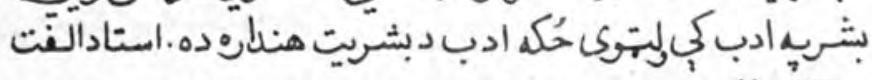

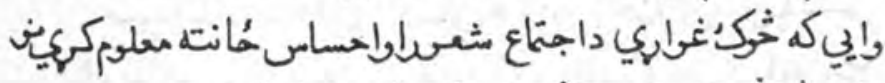

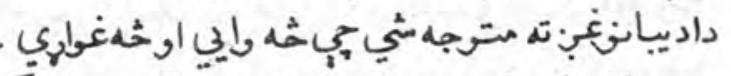

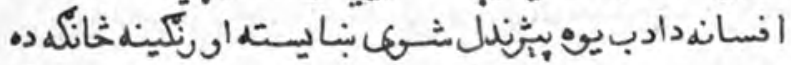

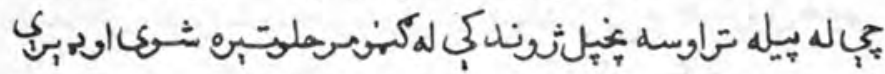

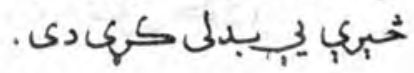




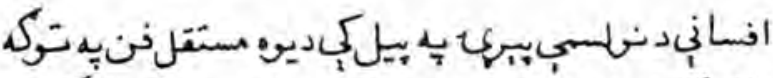

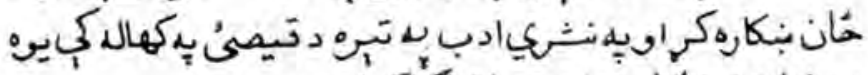

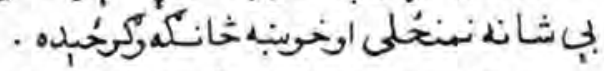

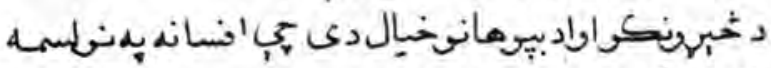

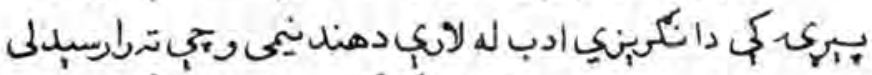

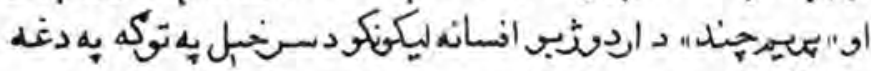

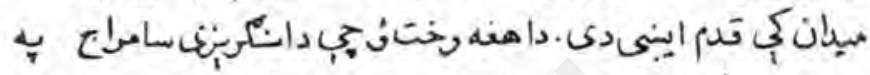

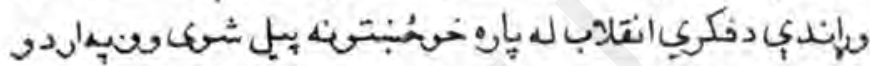

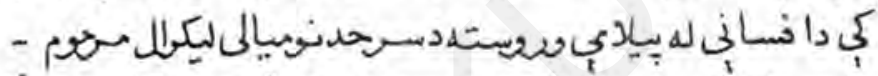

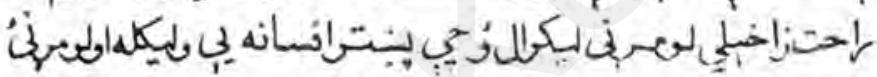

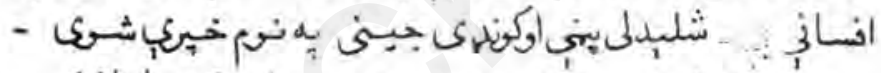

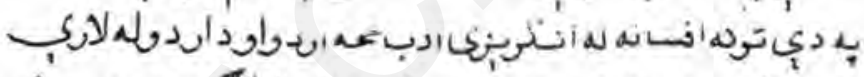

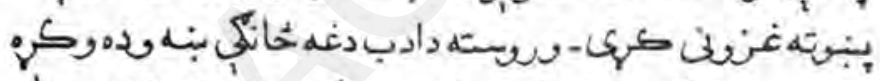

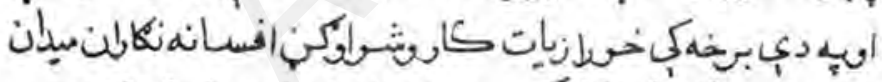

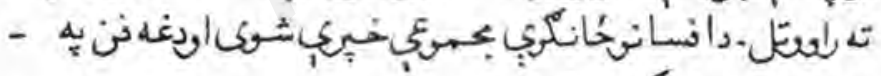

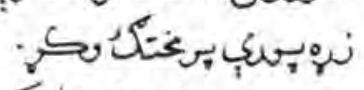

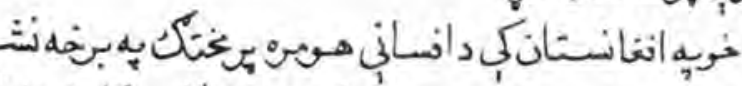

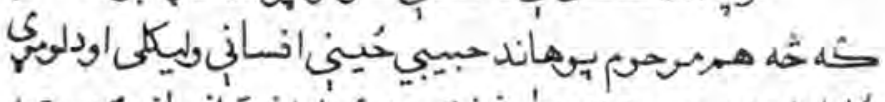

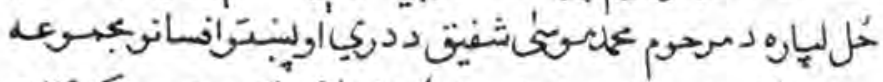

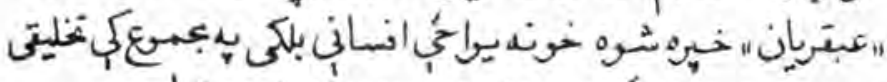

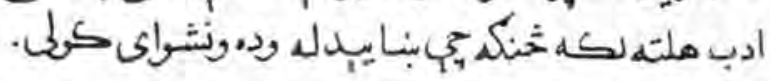




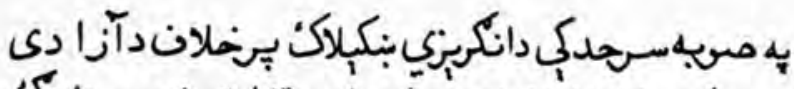

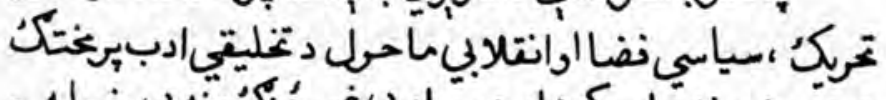

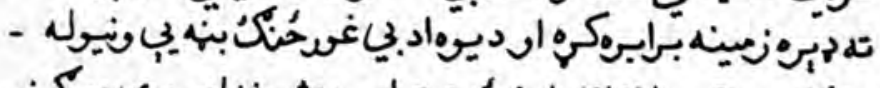

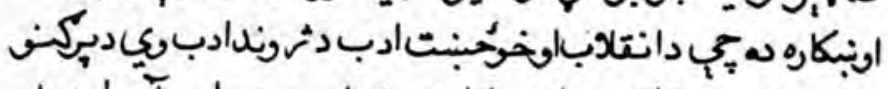

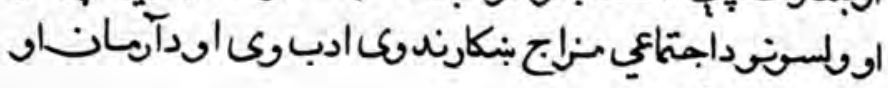
ينيام رلودونيكى ادب.

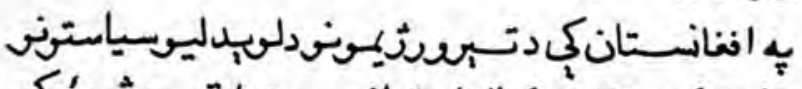

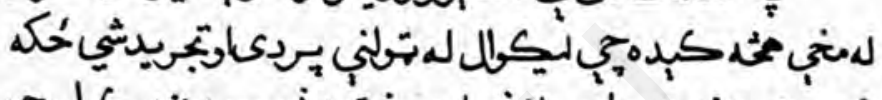

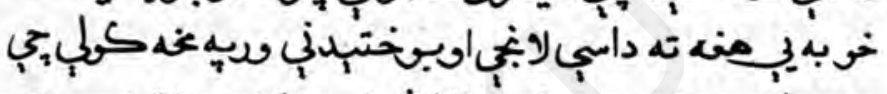

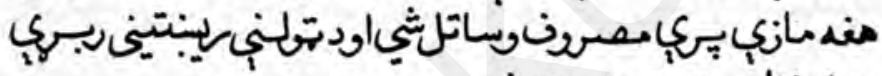

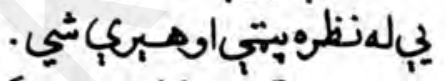

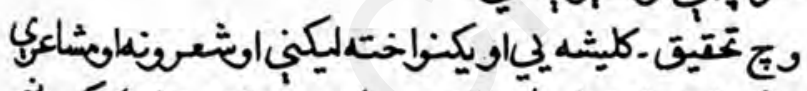

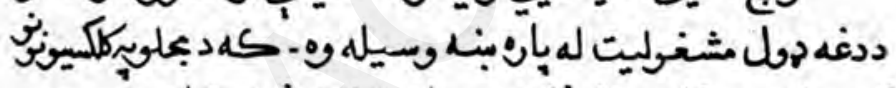

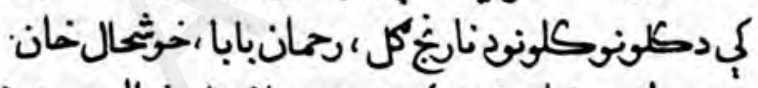

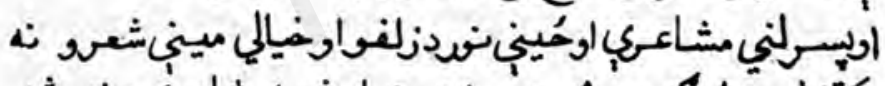

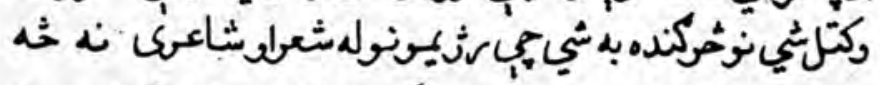

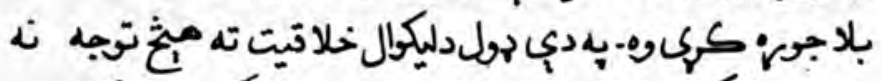

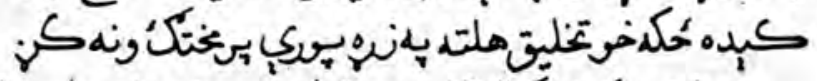

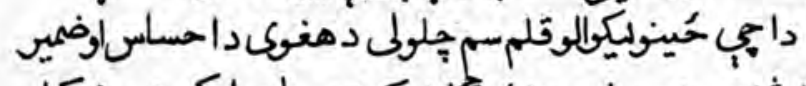

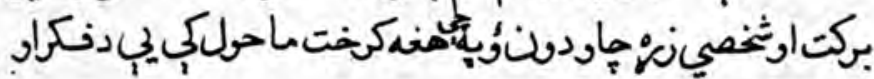
فنهيكيبلإكياني. 


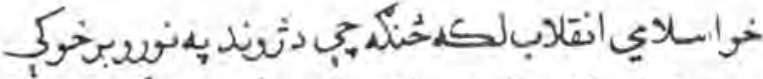

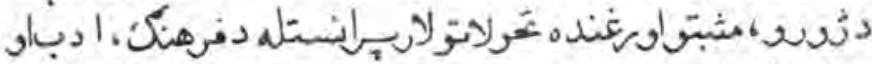

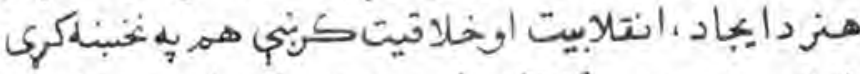

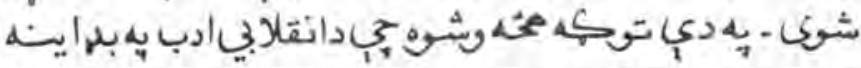

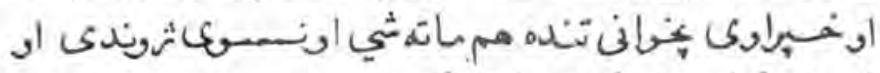

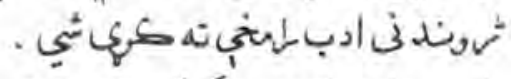

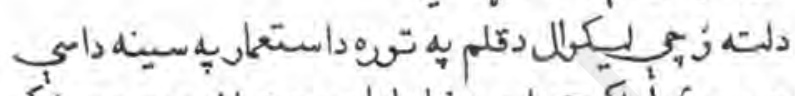

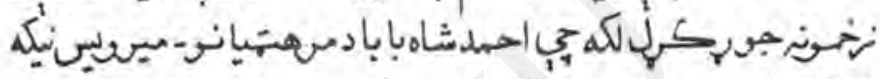

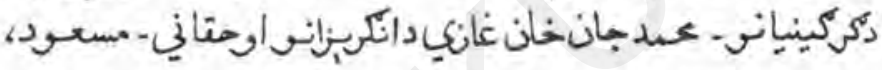

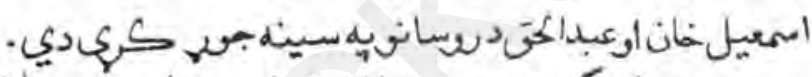

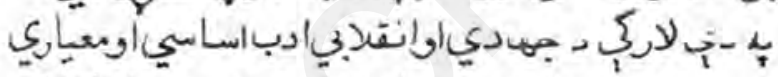

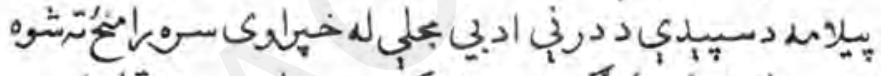

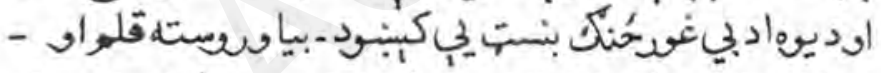

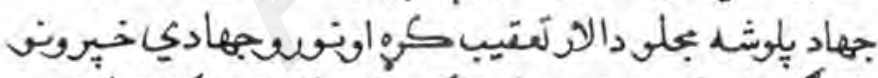

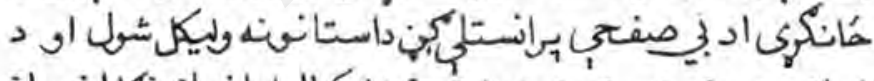

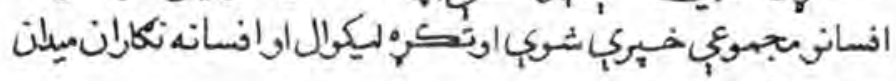

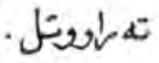

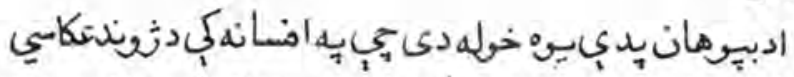

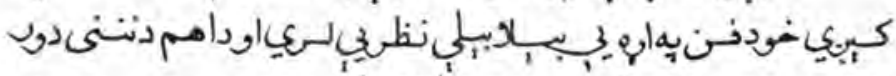

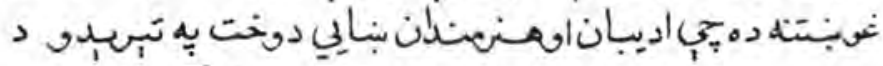

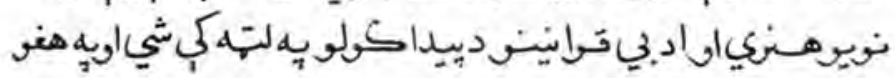




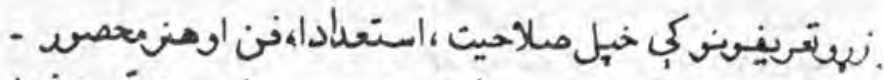

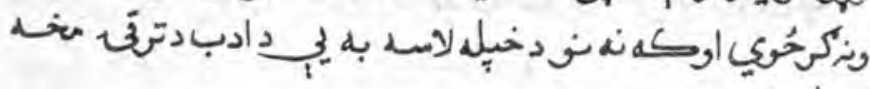

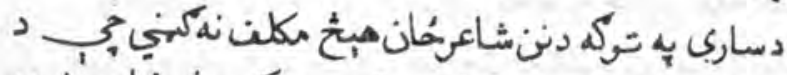

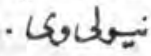

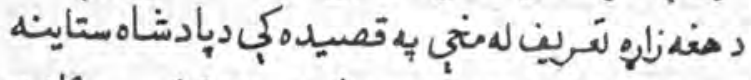

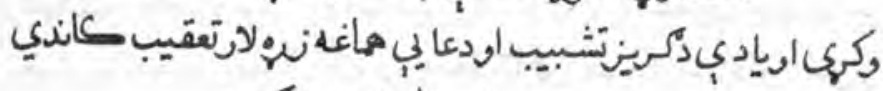

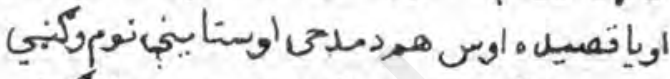

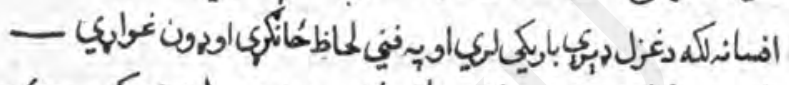

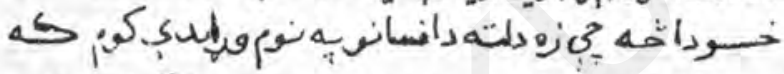

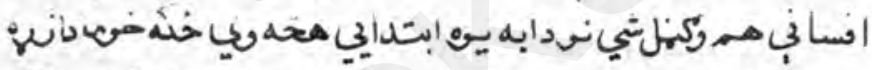

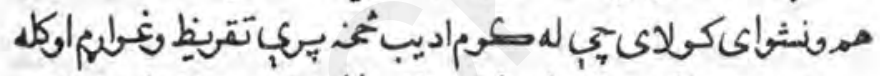

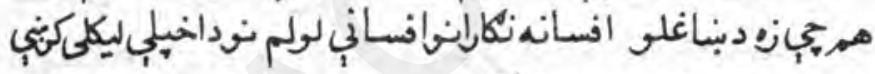

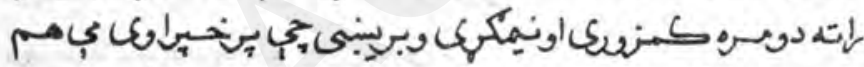

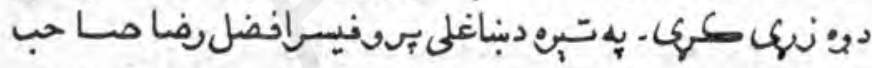

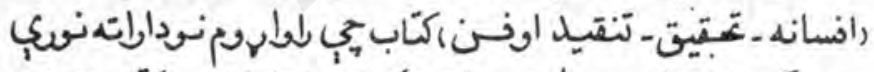

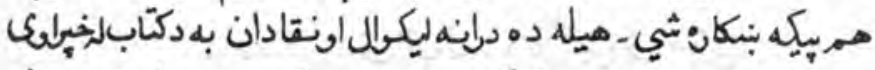

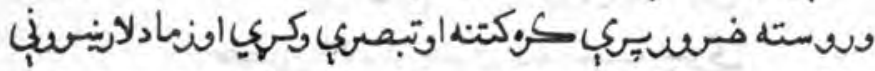

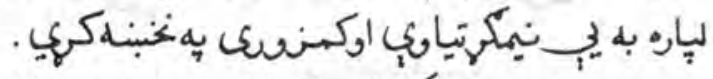

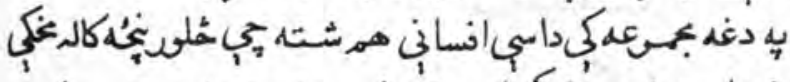

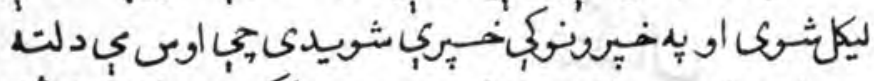

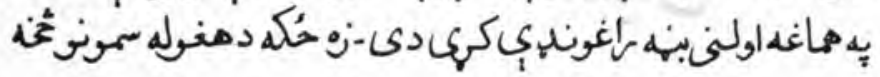




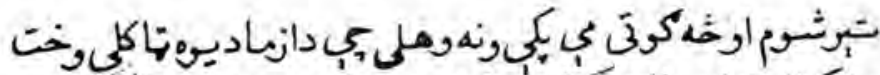

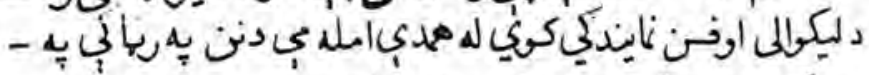

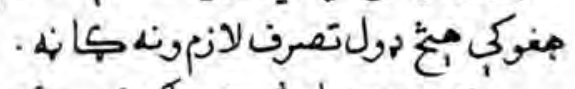

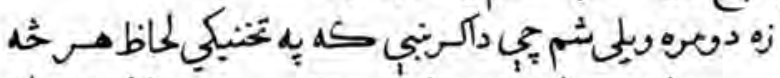

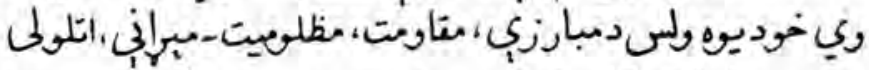

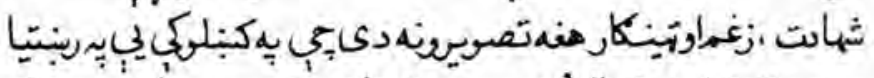

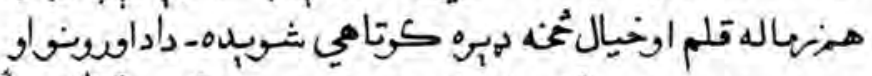

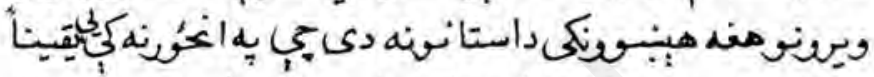

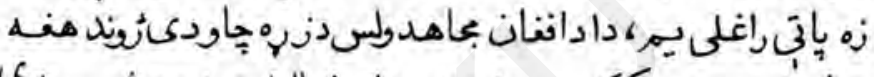

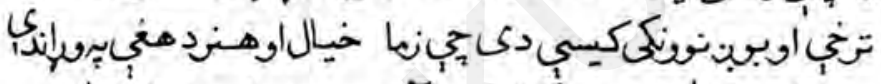

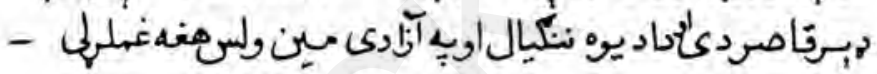

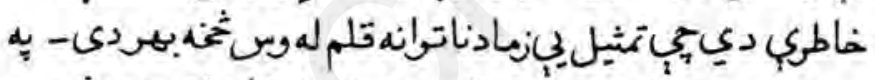

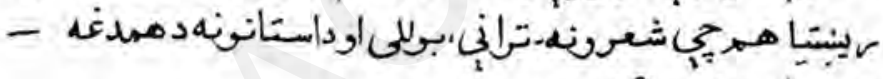

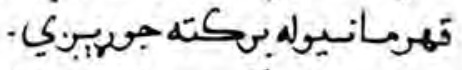

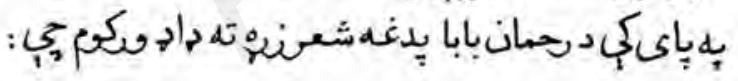

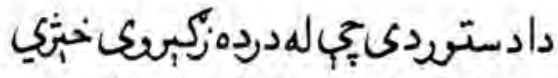

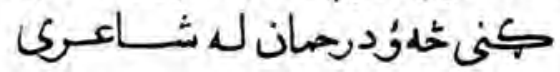

$$
\begin{aligned}
& \text { مينداورينبت } \\
& \text { ننكيال }
\end{aligned}
$$




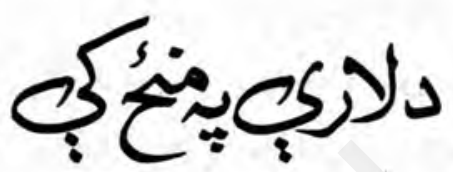

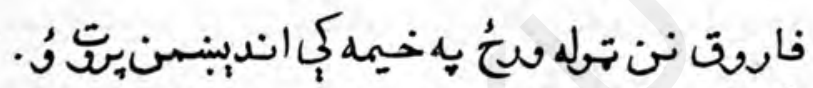

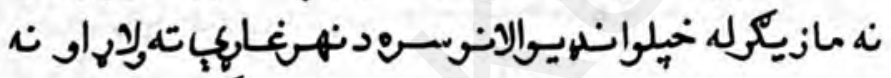

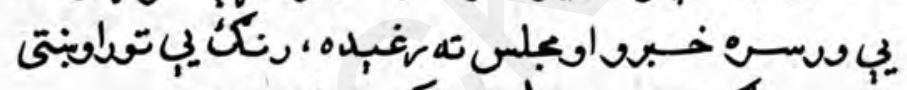

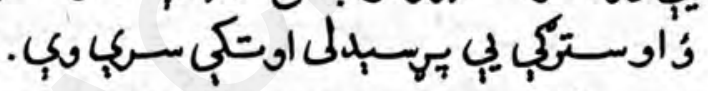

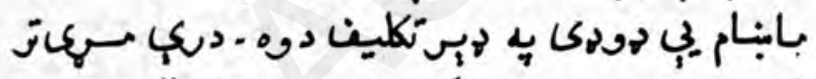

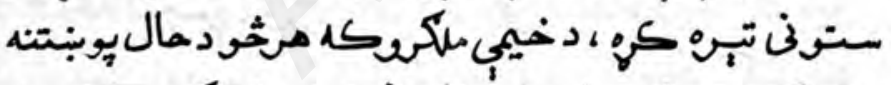

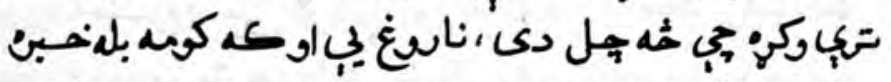

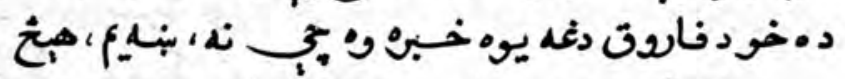

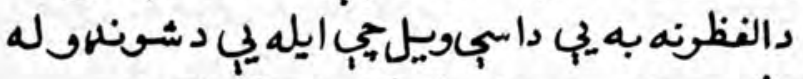

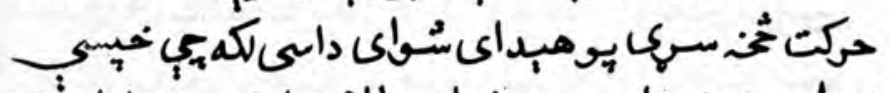

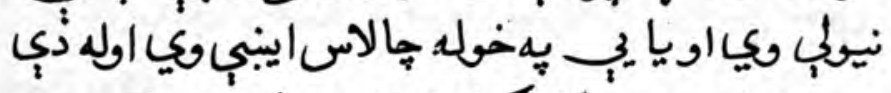

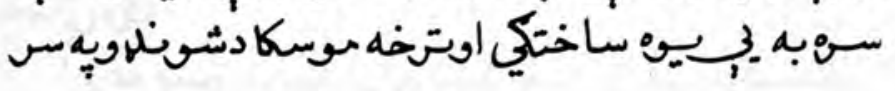

9 


\section{- ovilizás}

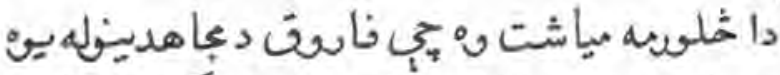

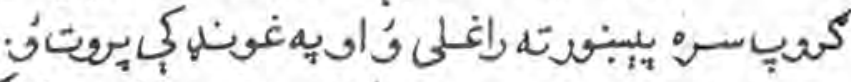

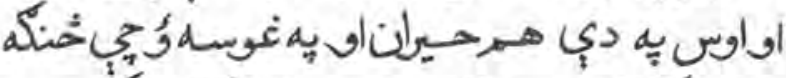

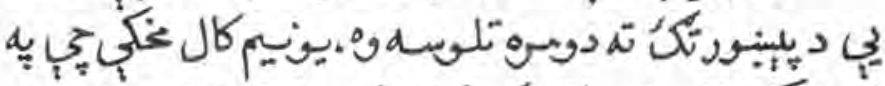

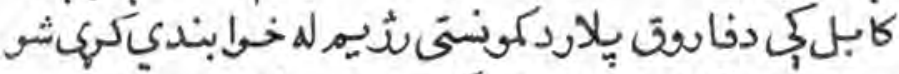

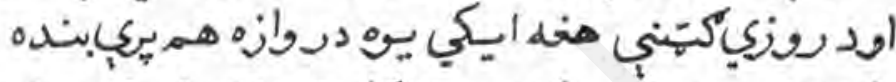

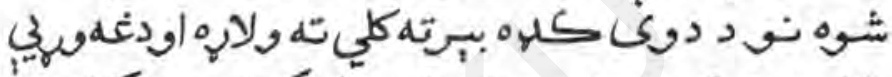

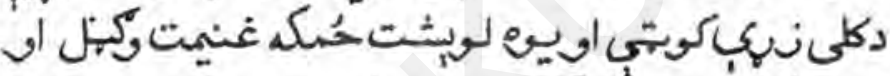

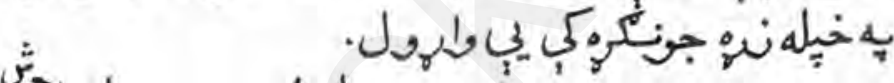

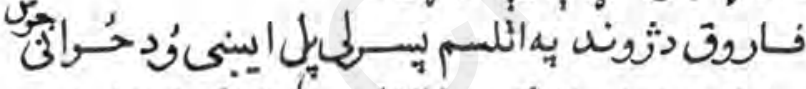

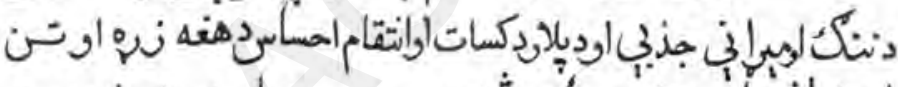

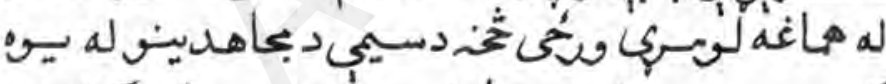

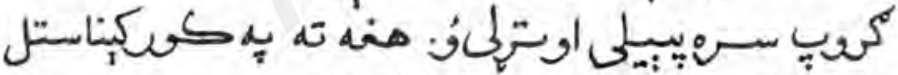

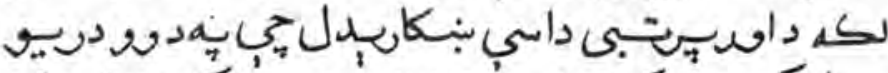

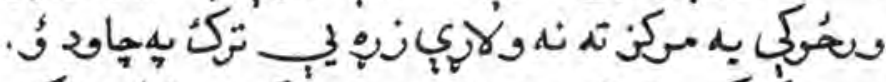

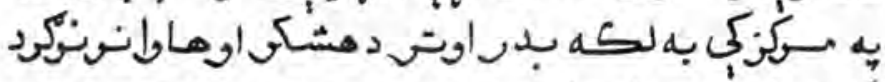

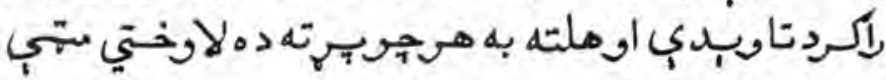

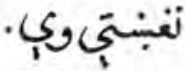

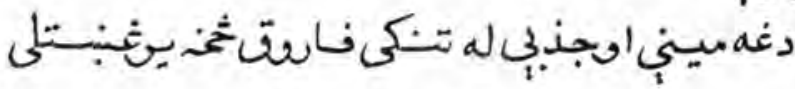




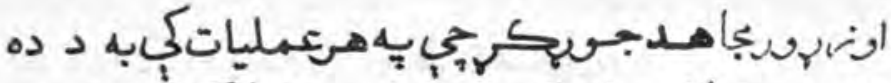

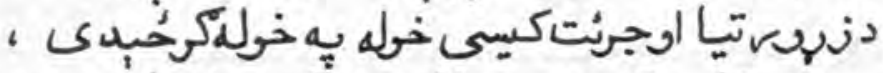

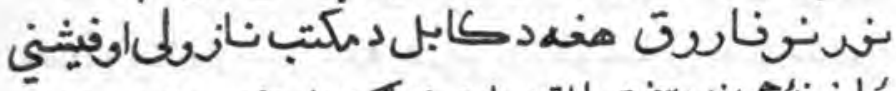

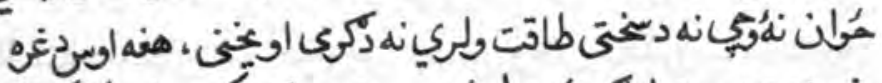

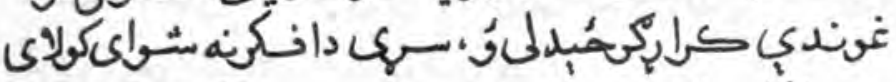

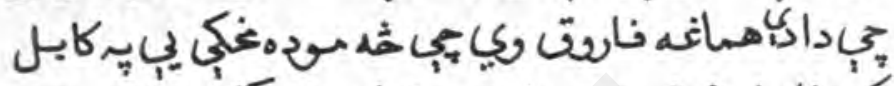

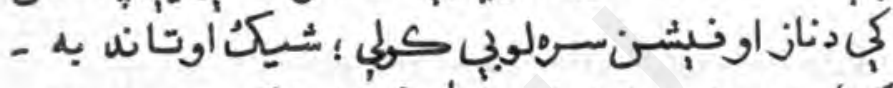

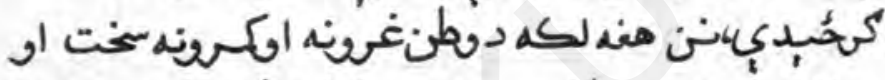

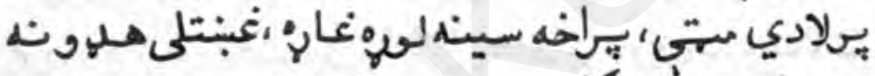

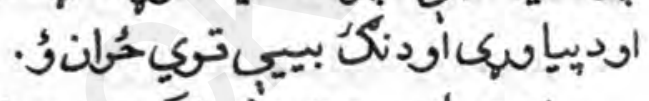

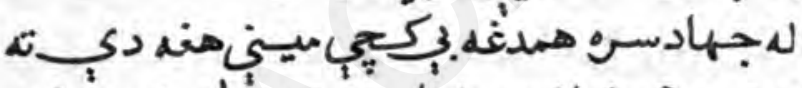

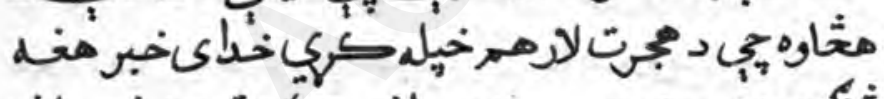

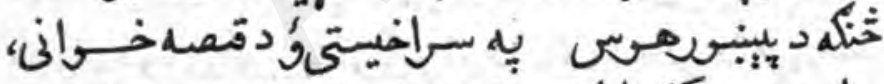

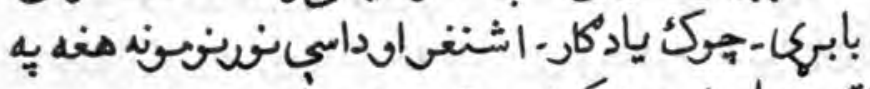

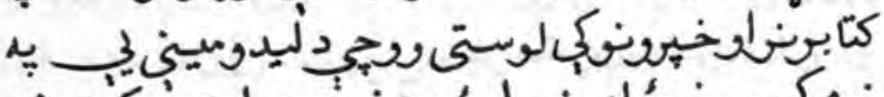

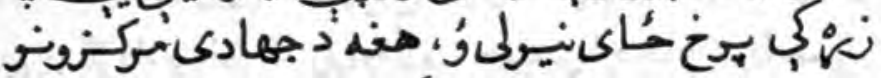

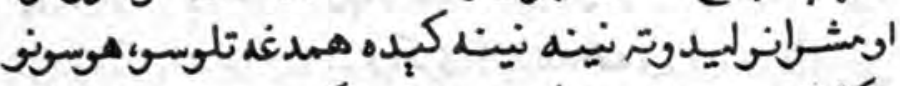

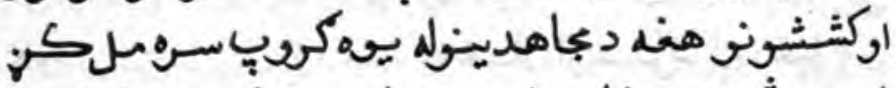

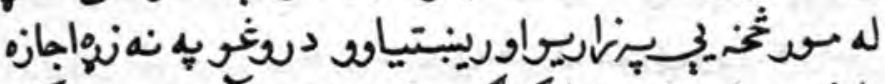

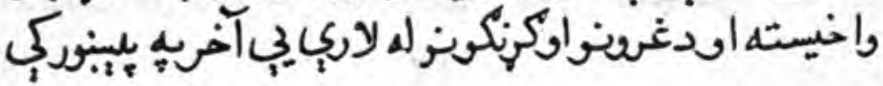




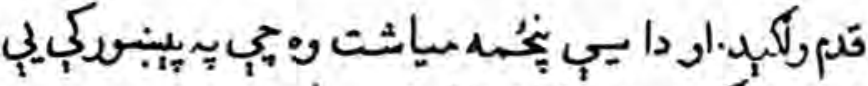

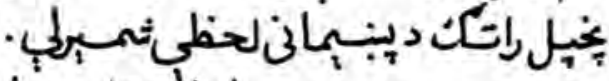

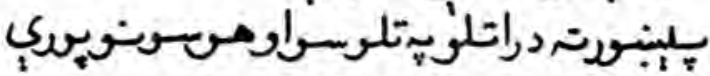

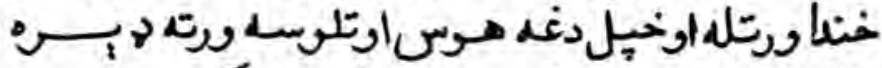

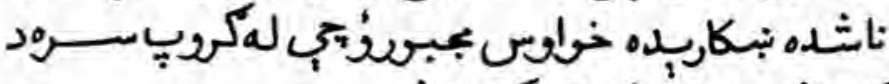

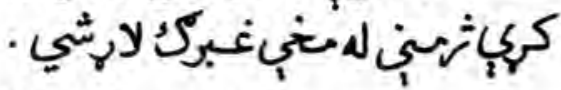

$$
\begin{aligned}
& \text { * * }
\end{aligned}
$$

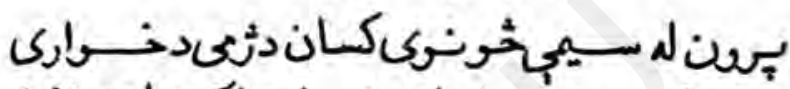

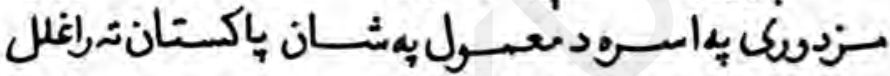

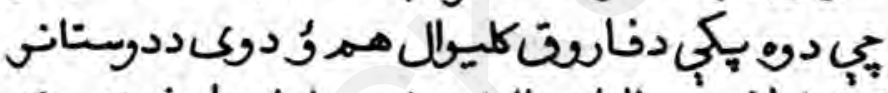

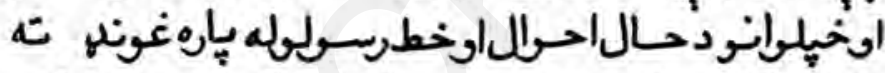

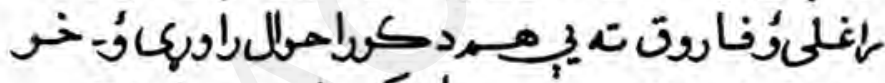

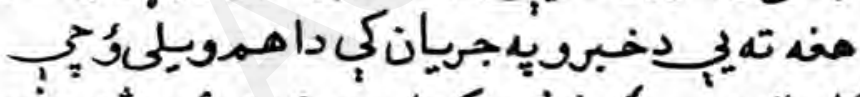

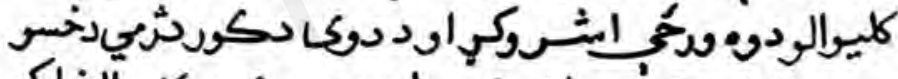

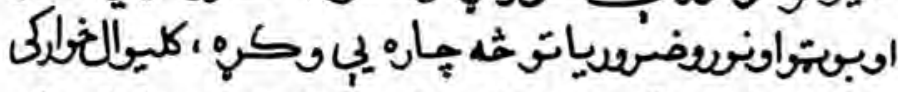

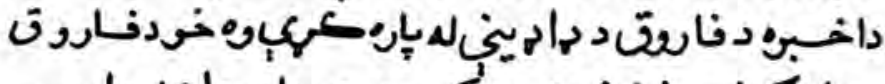

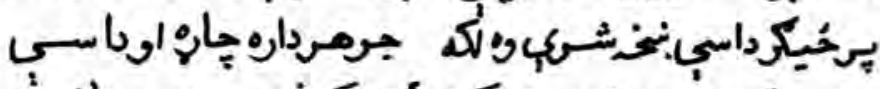

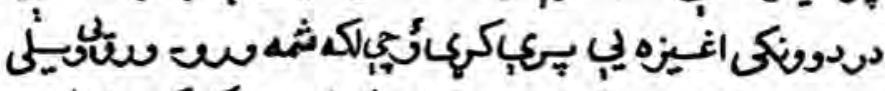

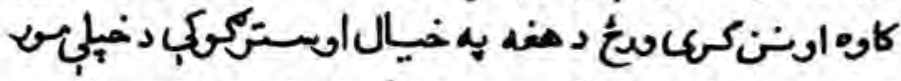

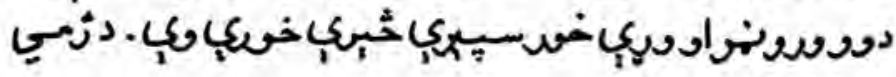




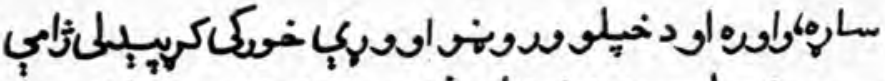

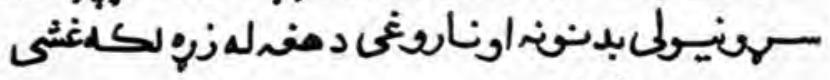
يصكاسكتل.

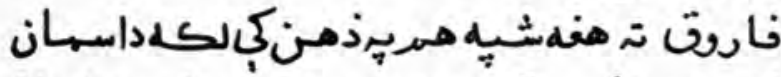

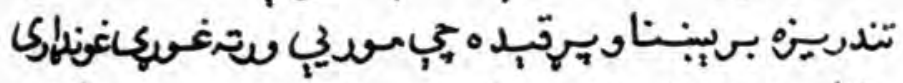

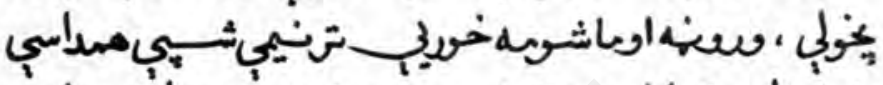

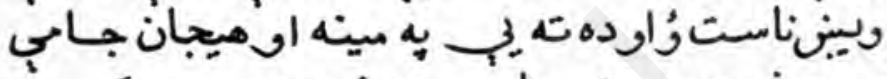

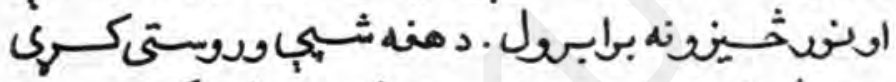

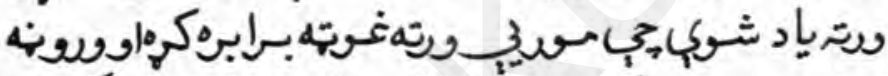

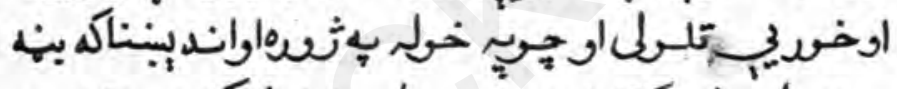

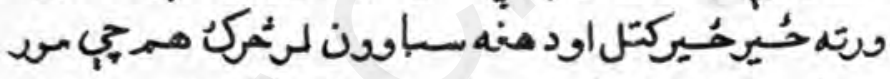

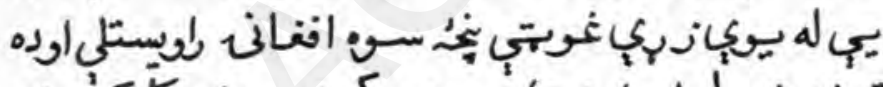

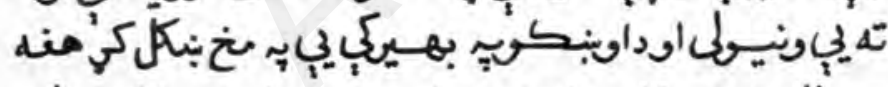

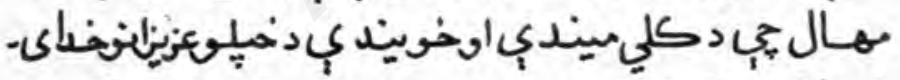

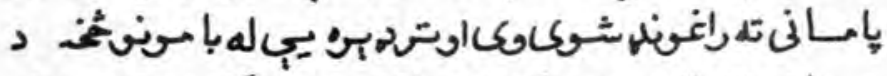

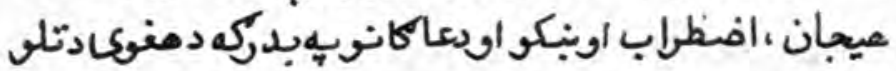

$$
\text { بلِون اولانو كتله. }
$$

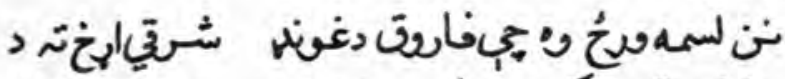

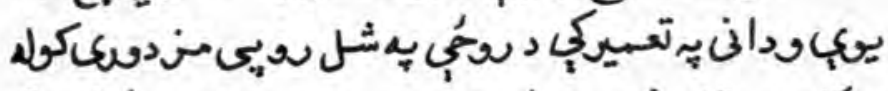

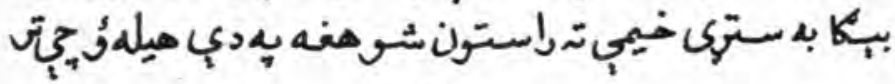




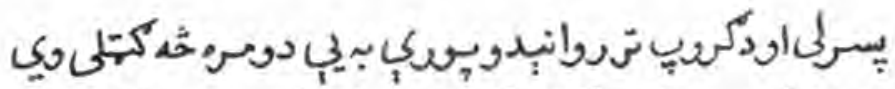

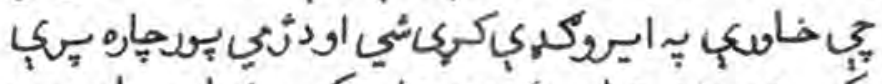

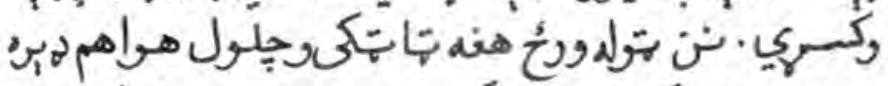

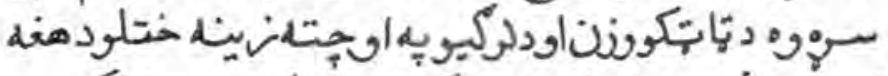

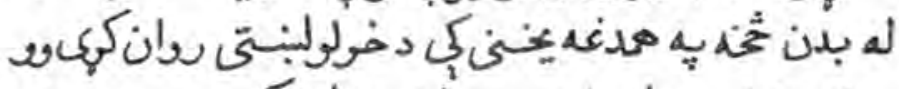

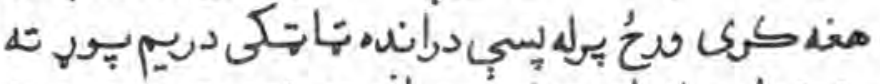

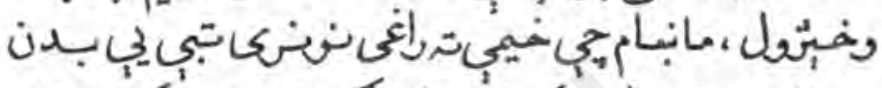

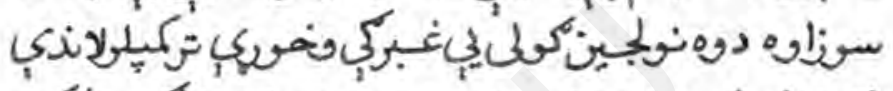

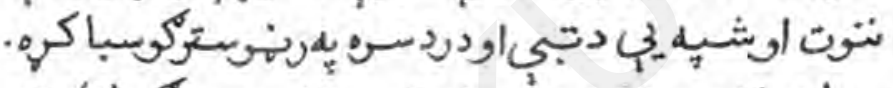

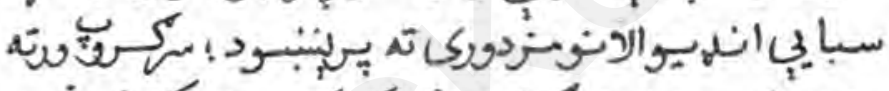

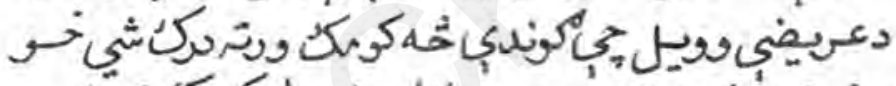

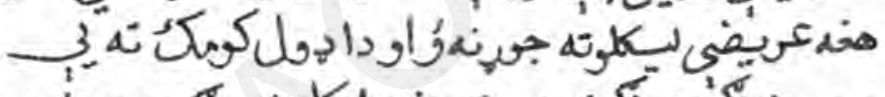

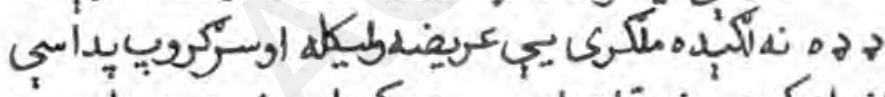

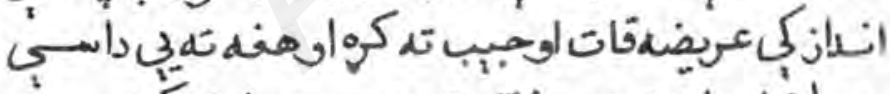

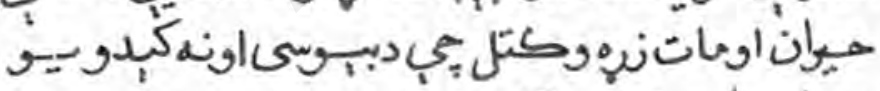

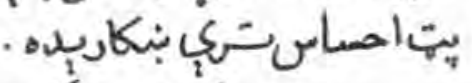

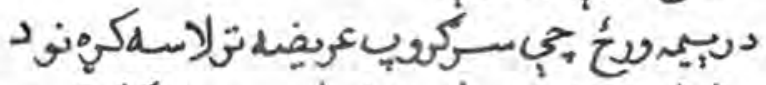

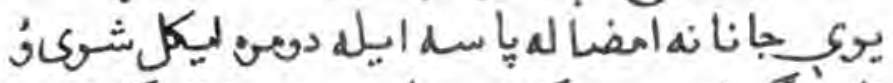

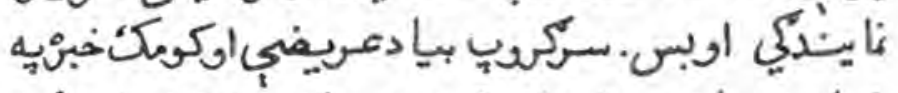

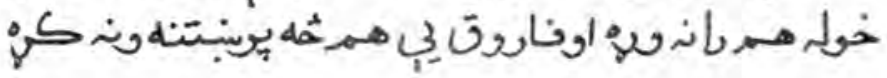




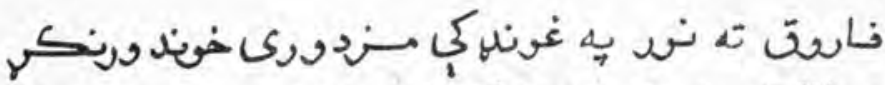

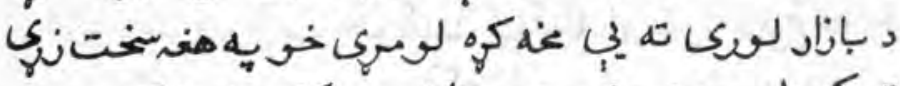

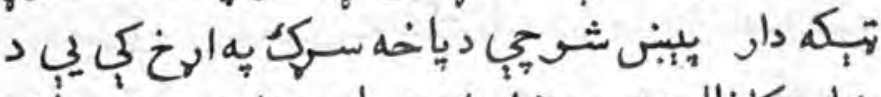

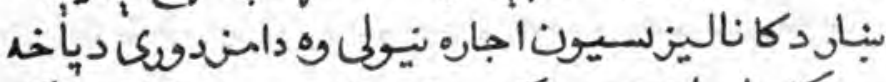

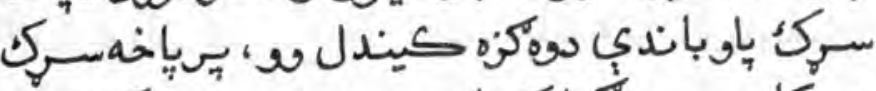

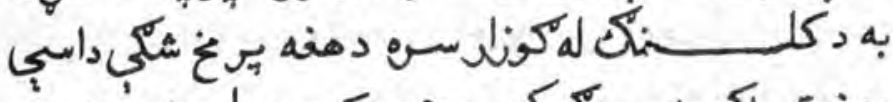

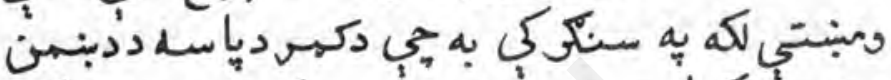

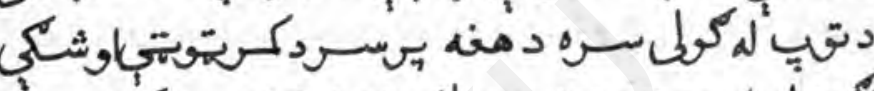

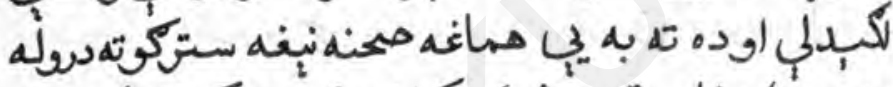

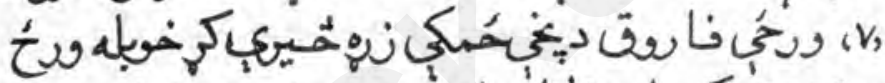

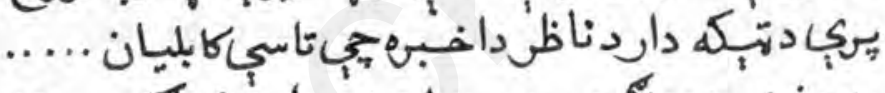

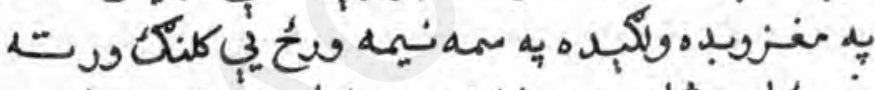

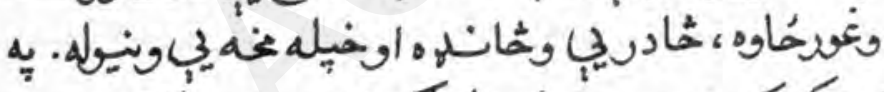

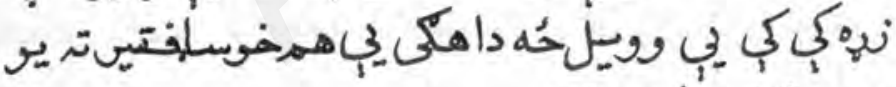

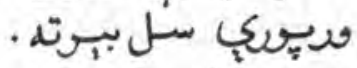

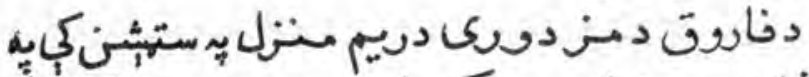

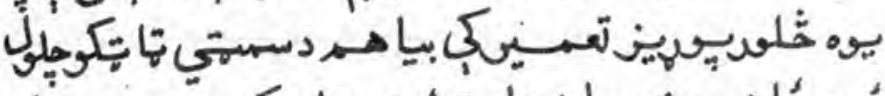

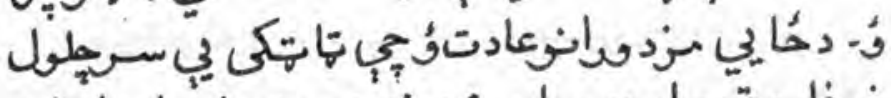

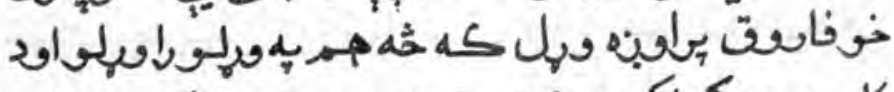

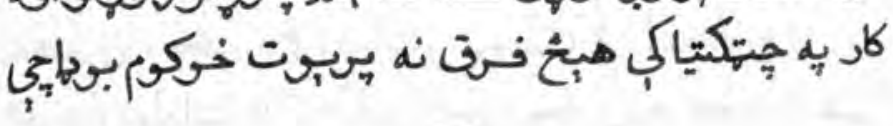




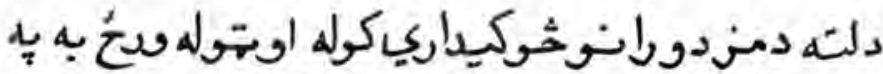

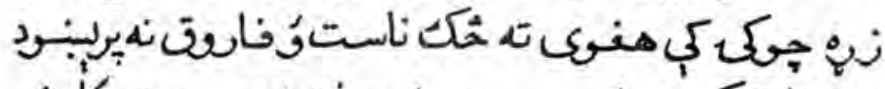

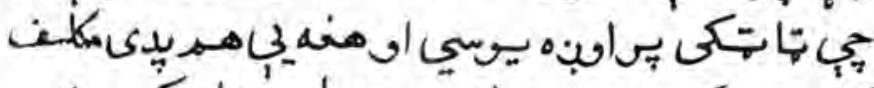

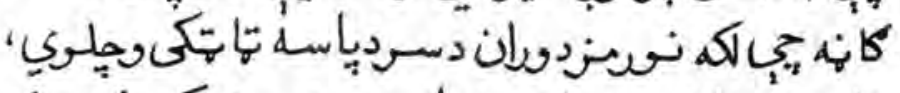

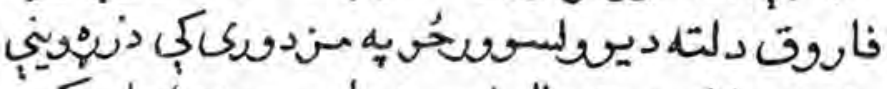

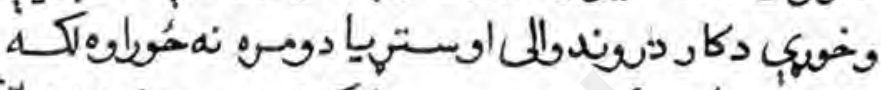

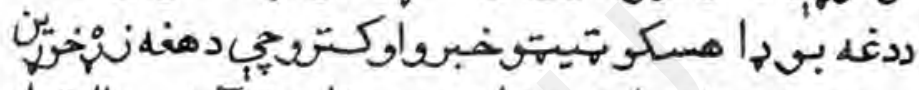

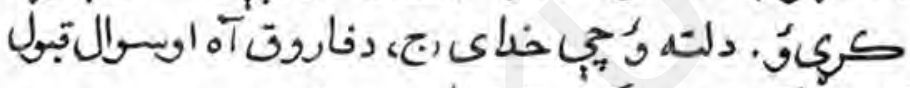

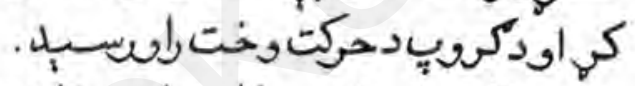

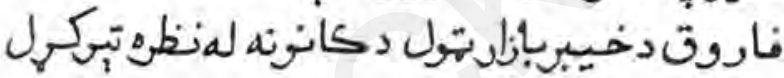

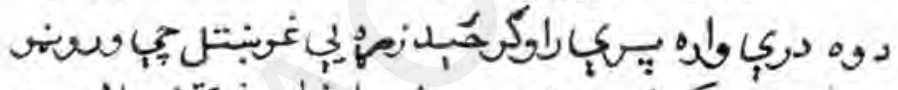

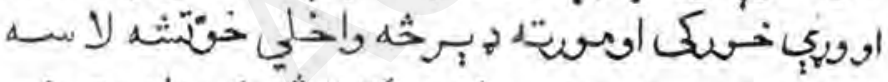

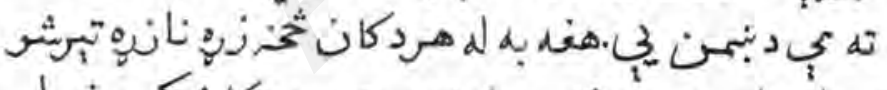

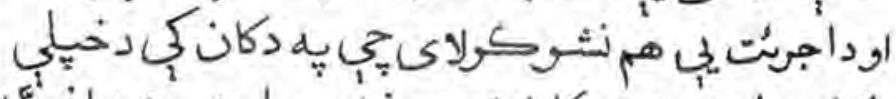

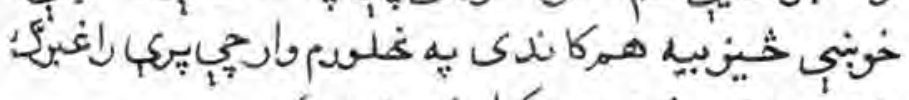

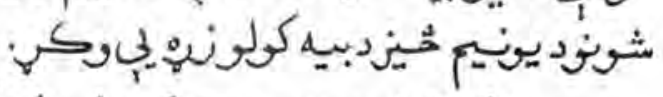

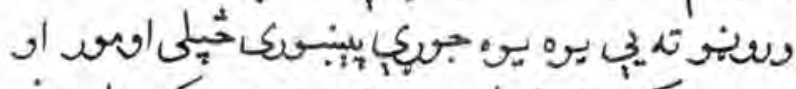

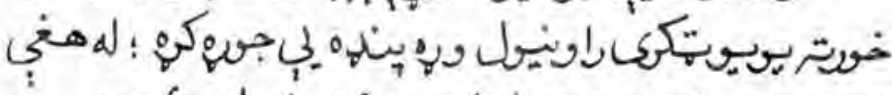

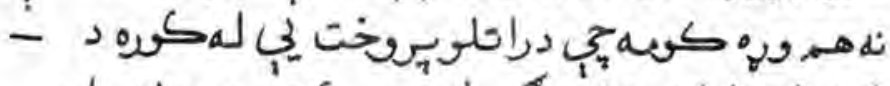

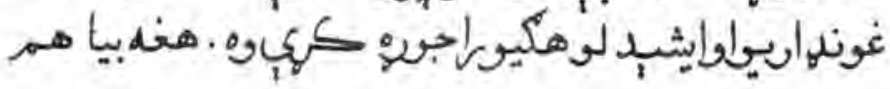




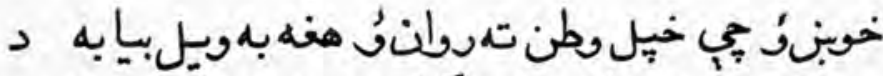

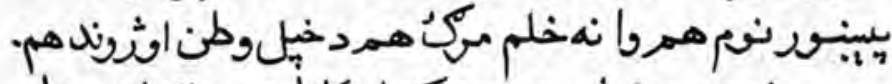

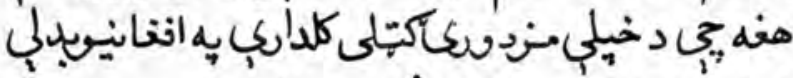

كي

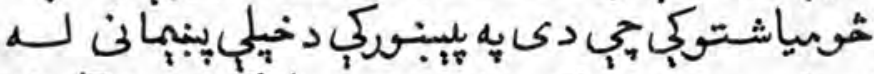

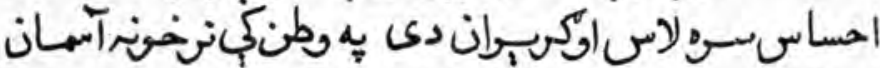
ته ختّلى

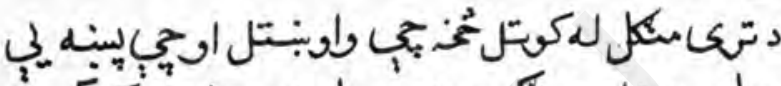

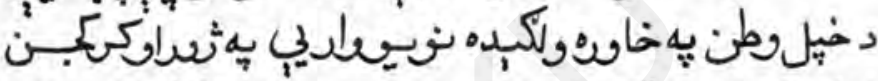

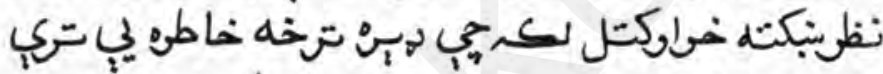

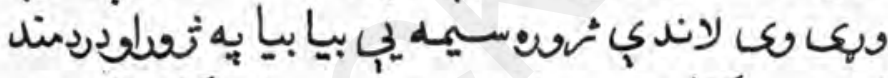

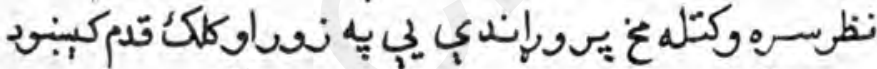

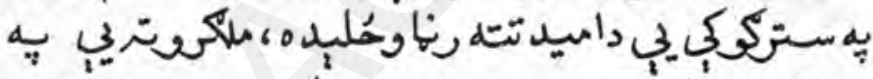

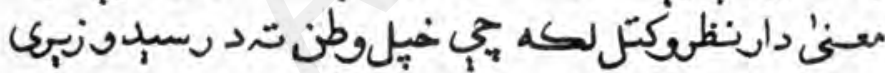

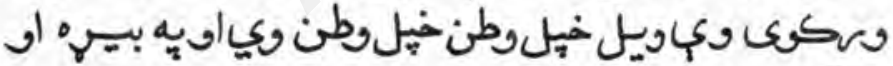

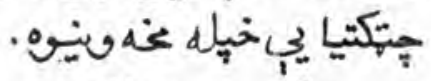

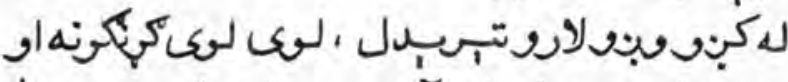

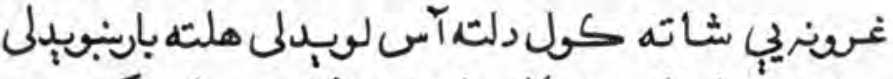

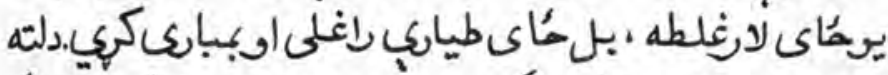

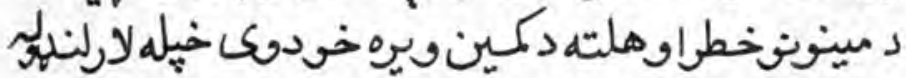




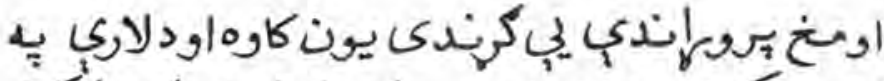

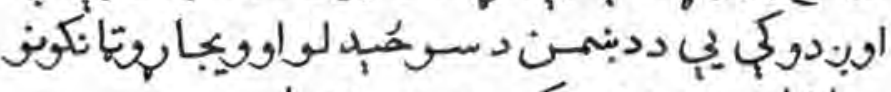

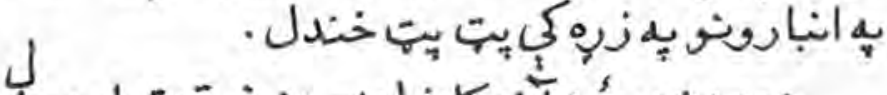

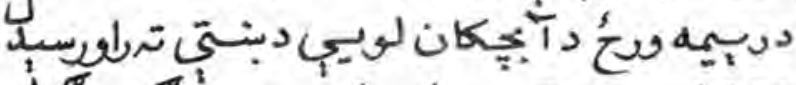

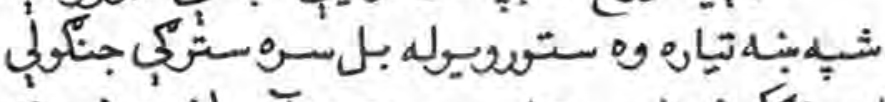

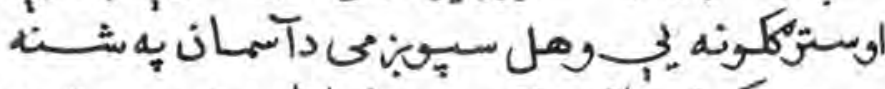

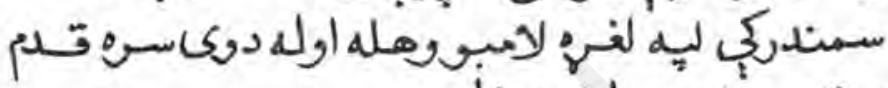

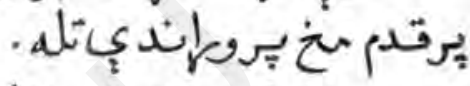

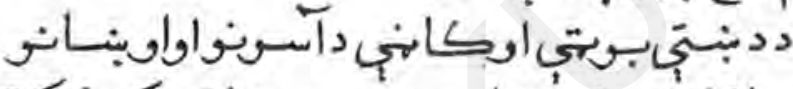

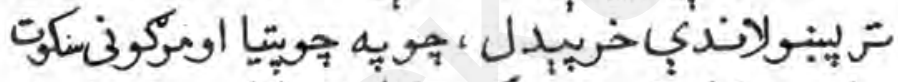

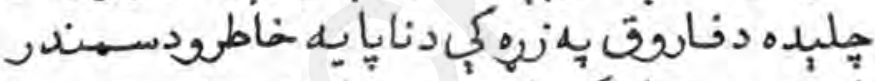

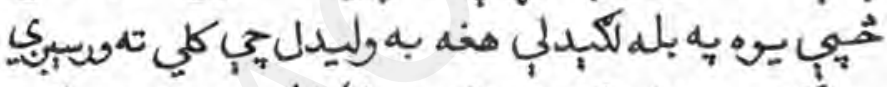

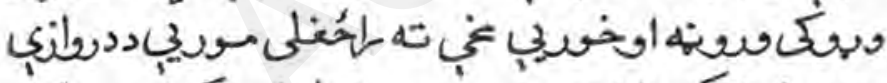

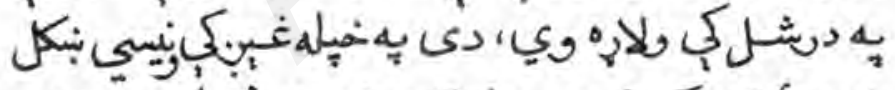

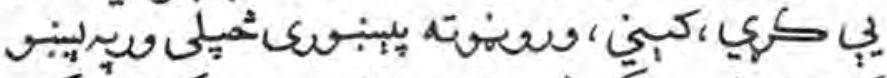

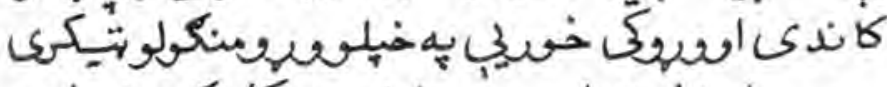

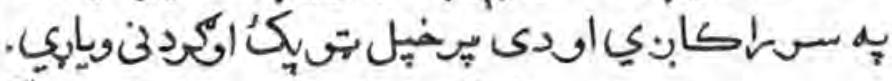

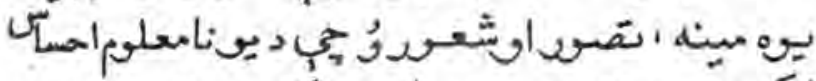

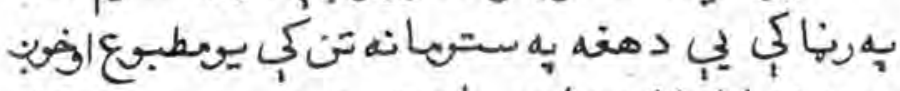

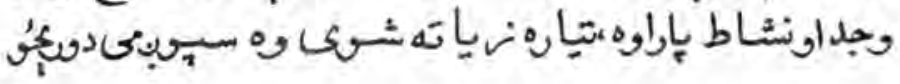




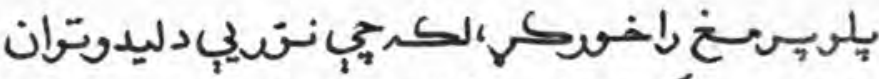

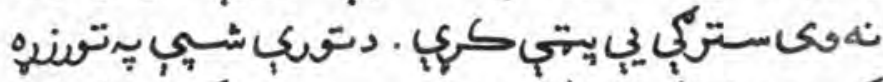

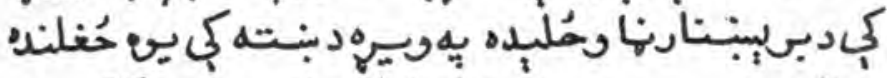

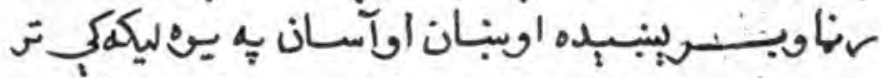

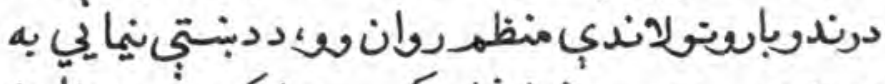

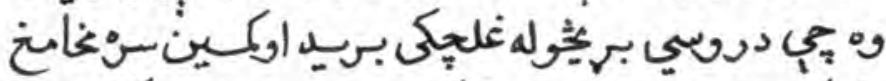

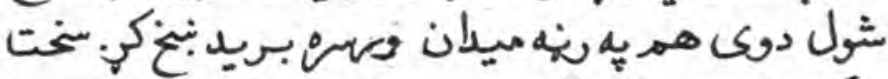

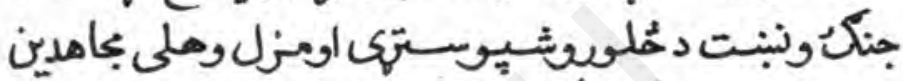

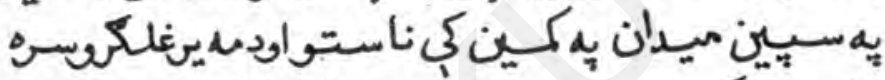

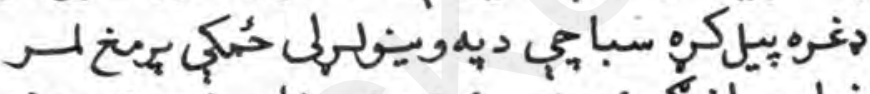

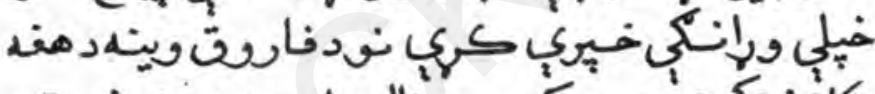

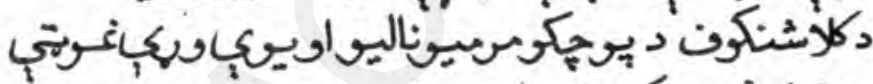

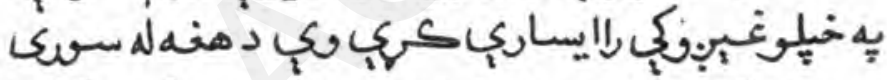

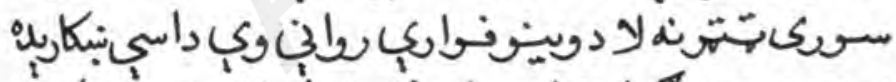

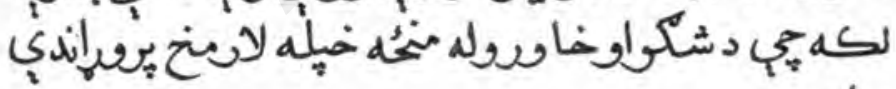

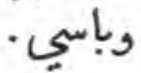


pe 


\section{تورلست}

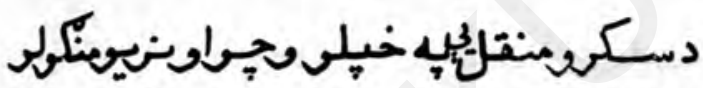

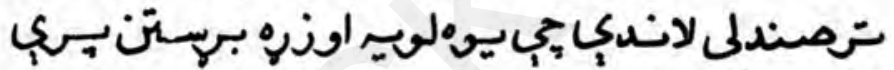

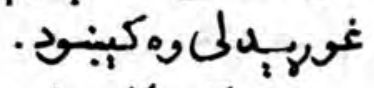

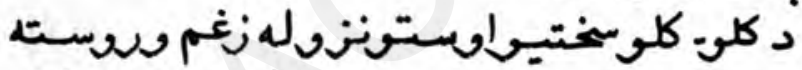

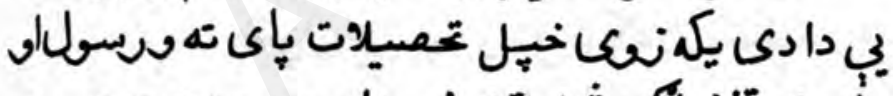

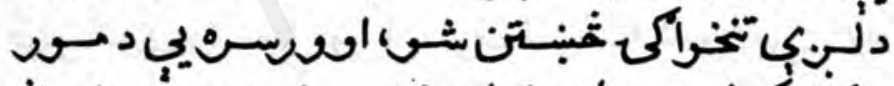

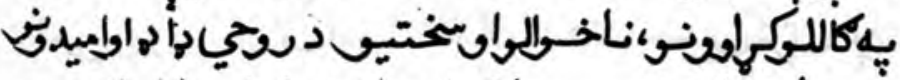

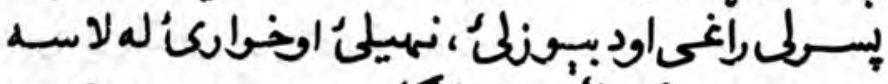

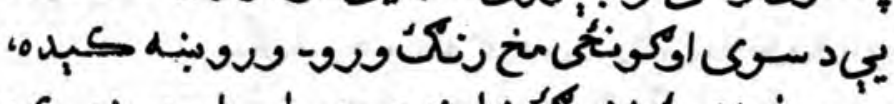

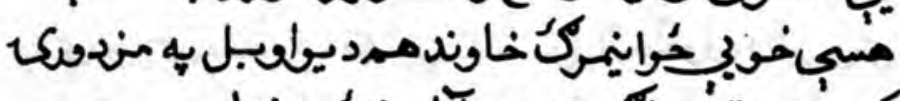

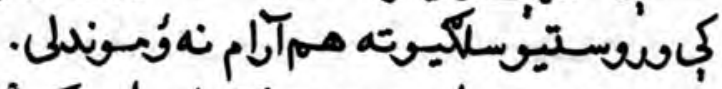

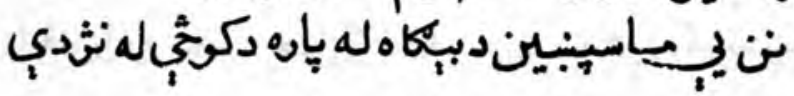




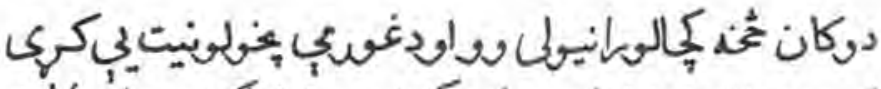

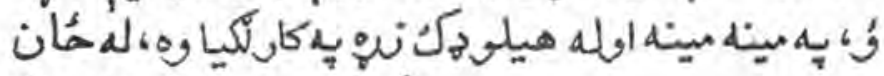

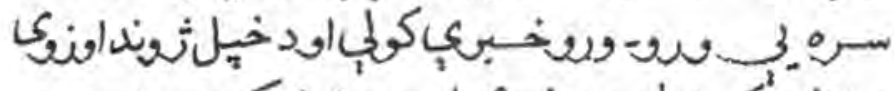

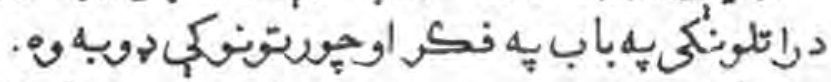

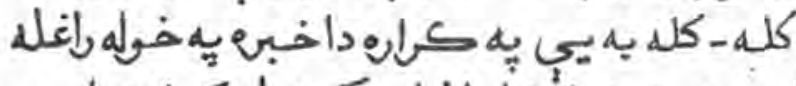

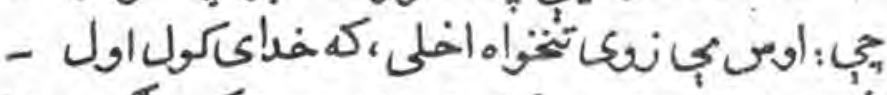

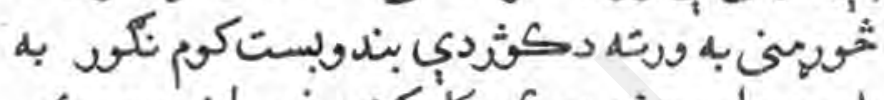

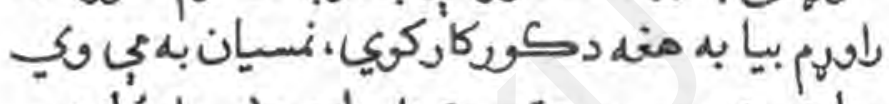

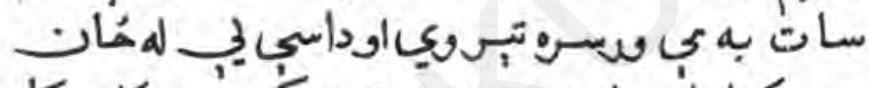

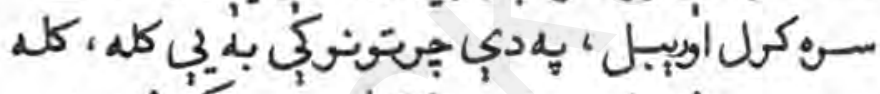

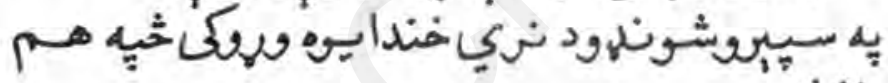
إغله.

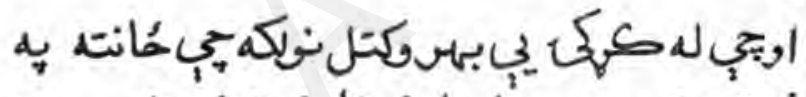

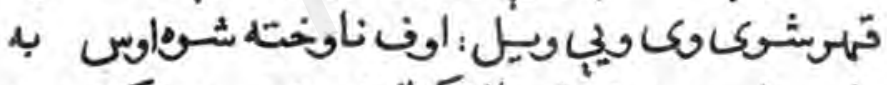

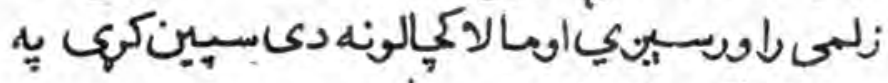

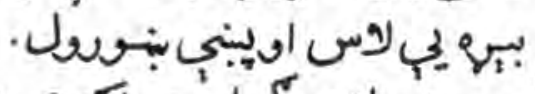

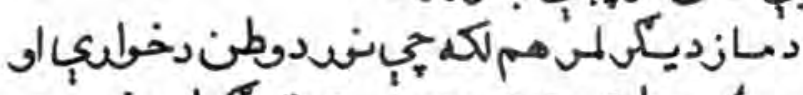

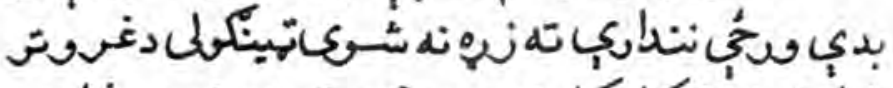

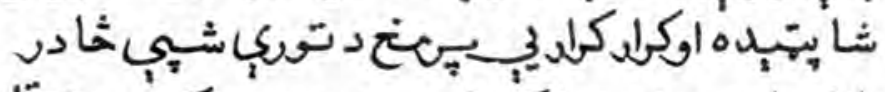

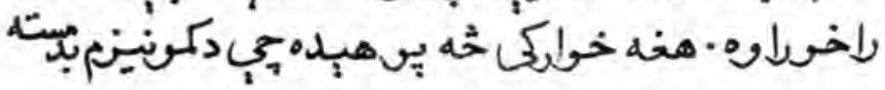




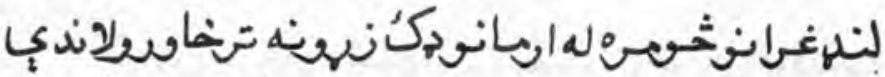

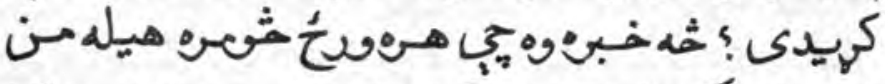

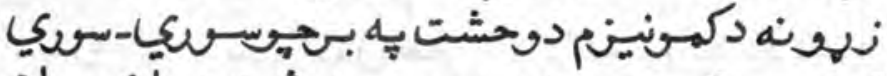

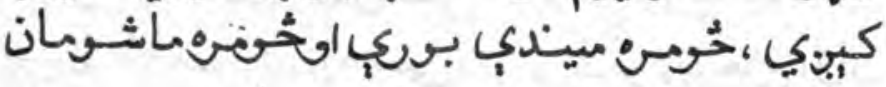

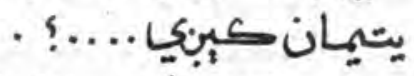

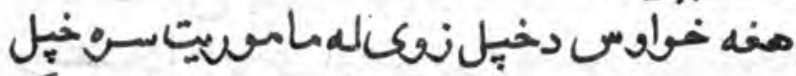

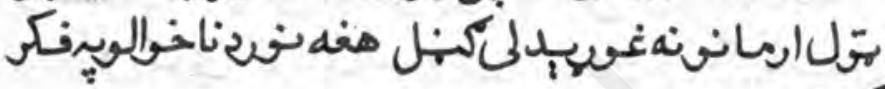
كإنها

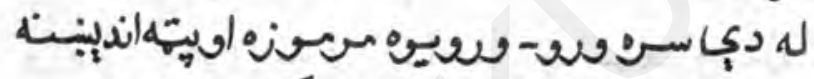

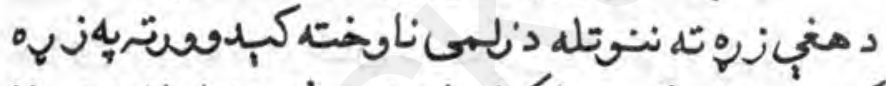

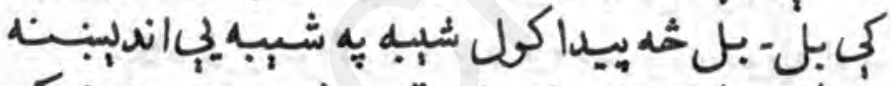

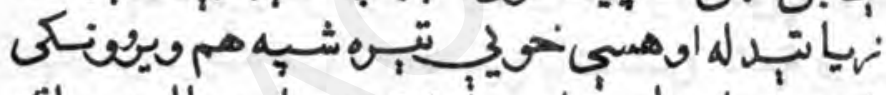

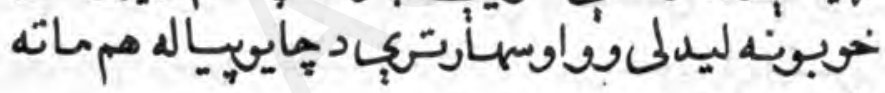

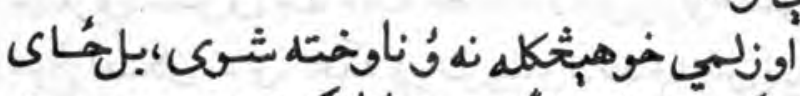

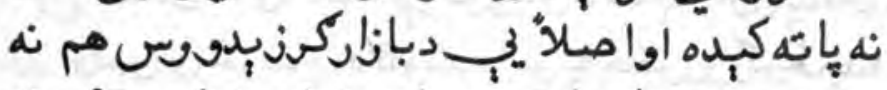

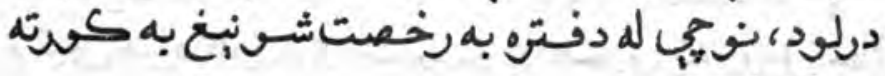

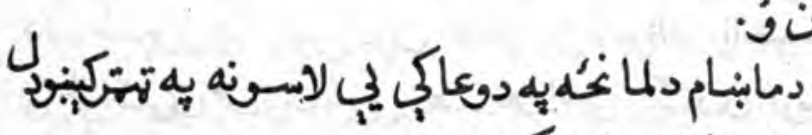

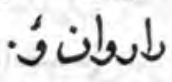

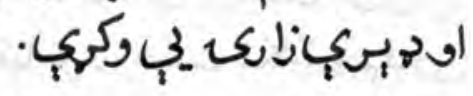




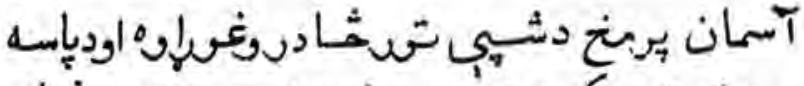

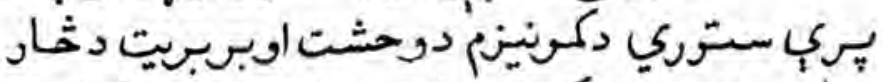

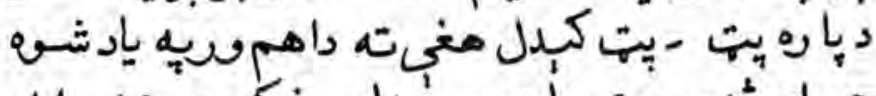

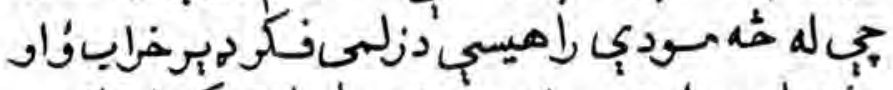

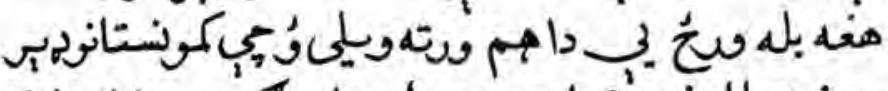

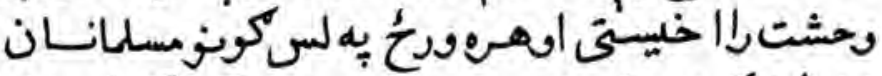

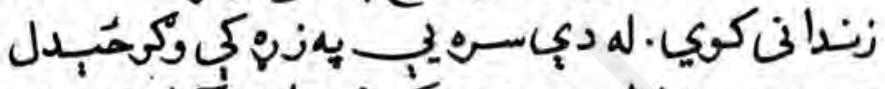

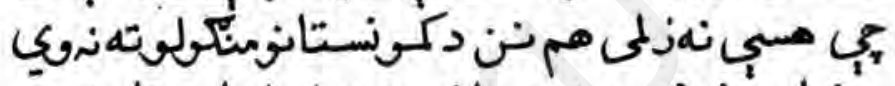

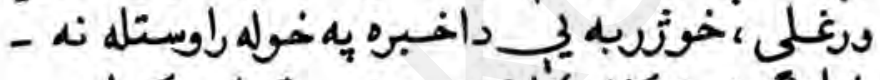

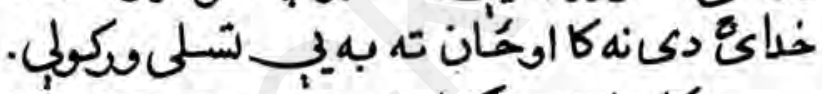

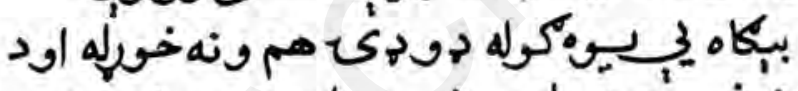

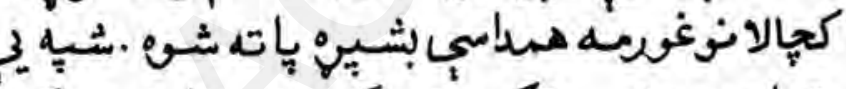

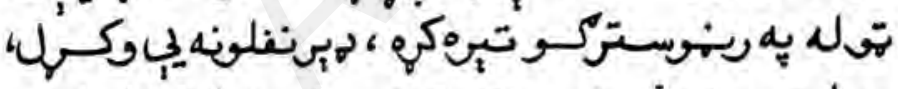

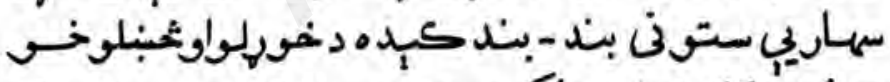

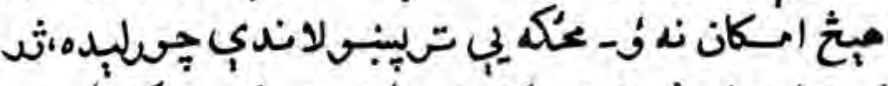

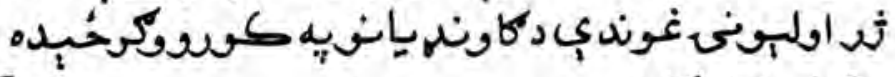

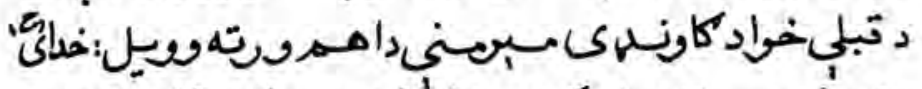

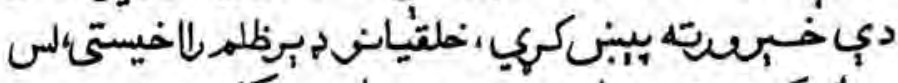

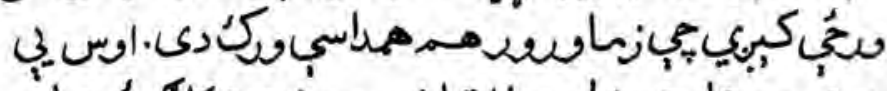

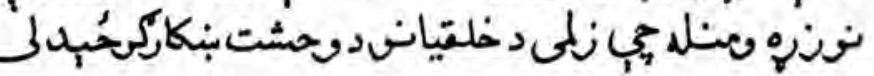




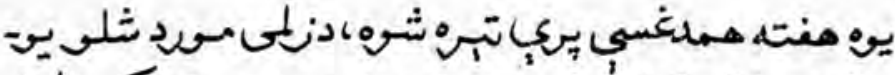

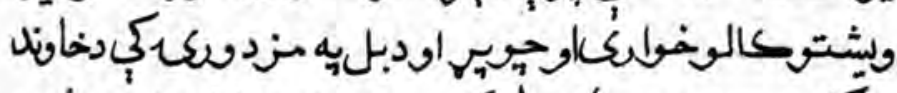

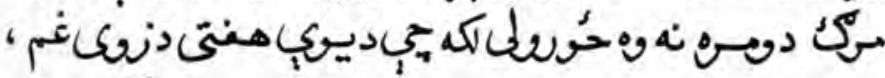

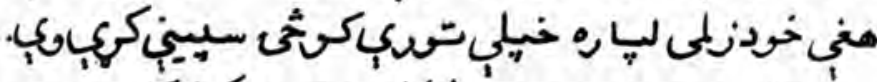

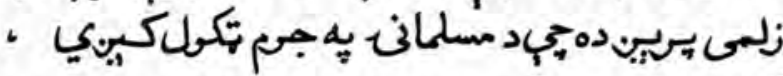

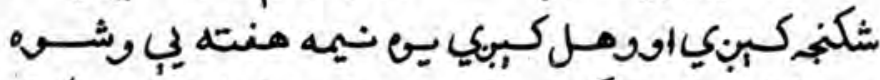

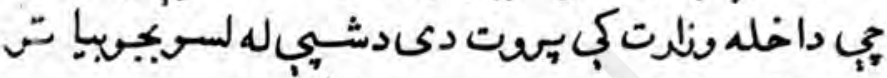

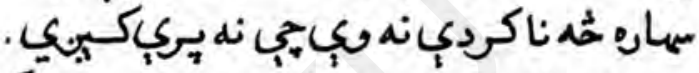

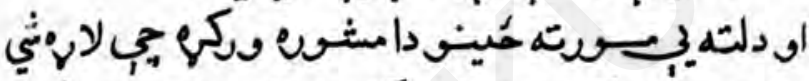

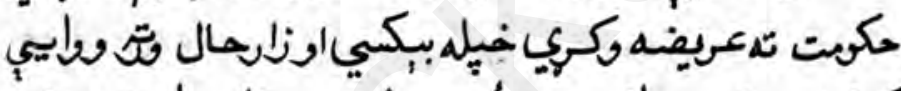

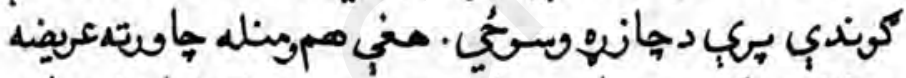

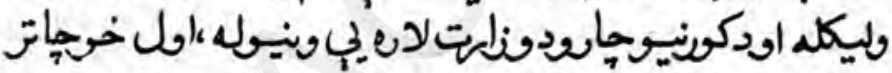

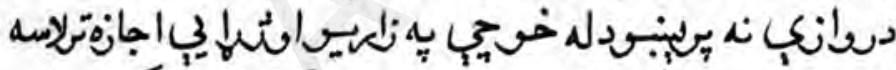

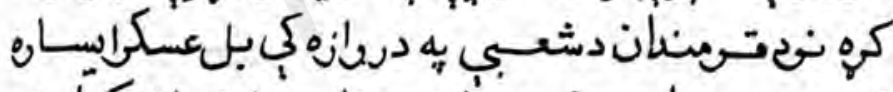

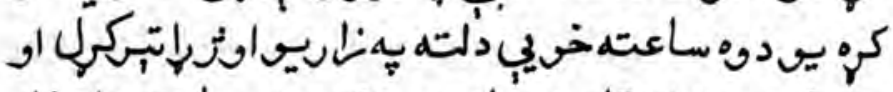

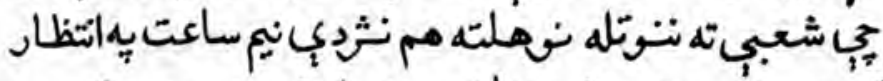

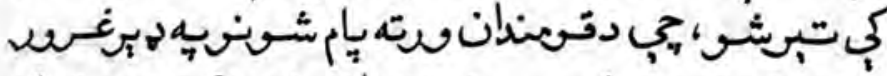

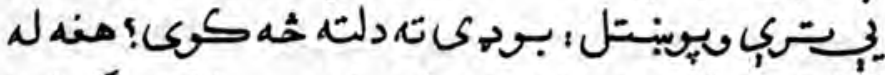

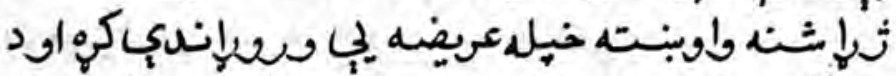

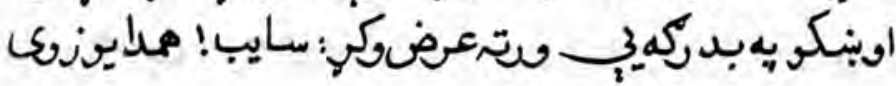




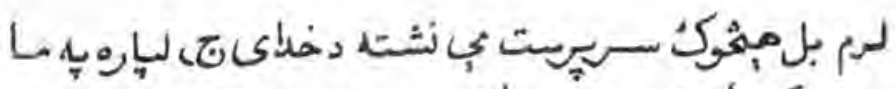

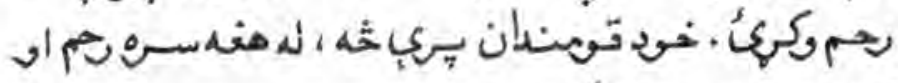

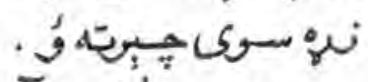

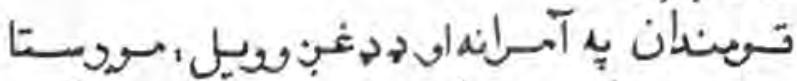

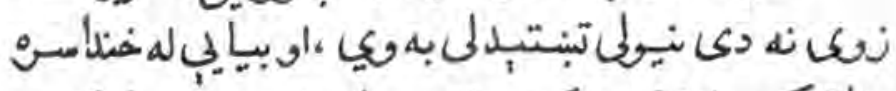

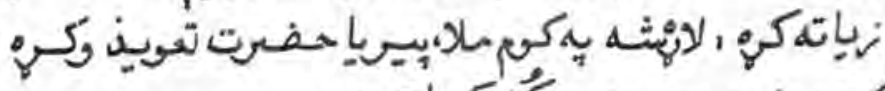

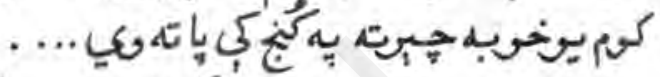

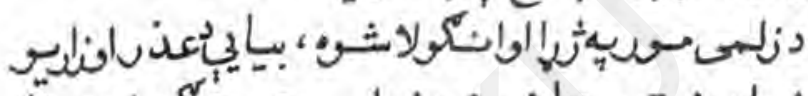

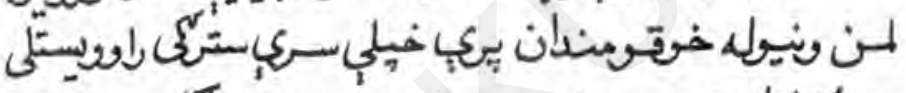

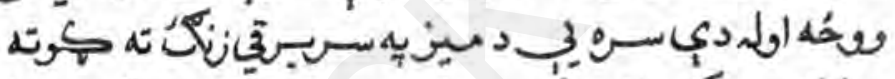

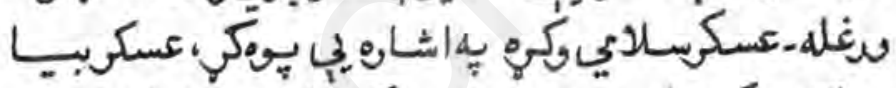

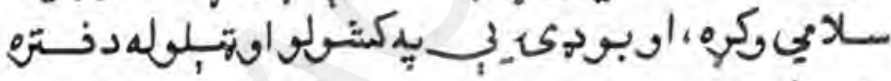
ويستله .

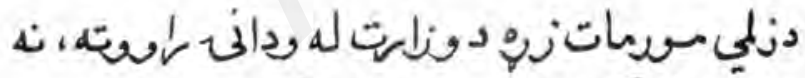

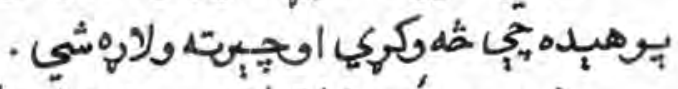

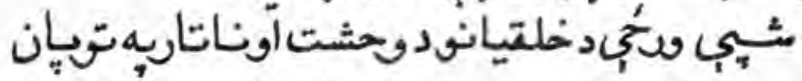

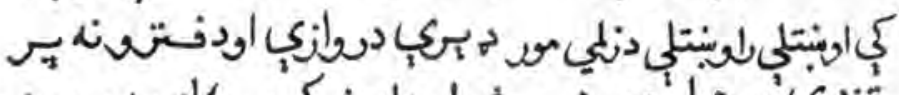

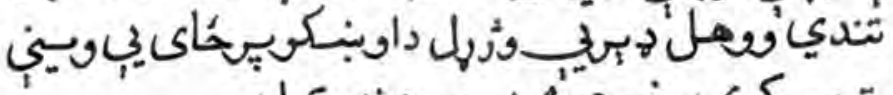

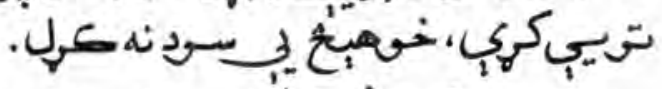

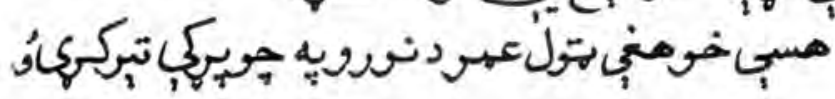
דr 


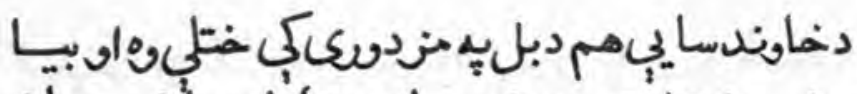

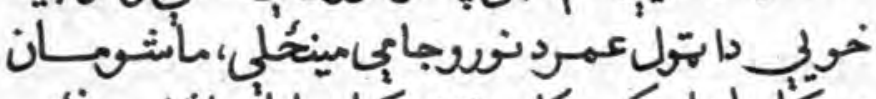

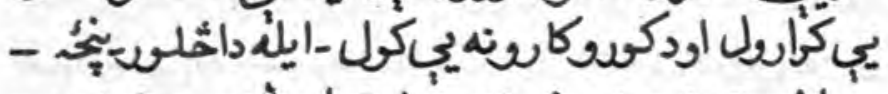

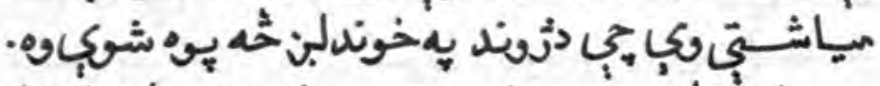

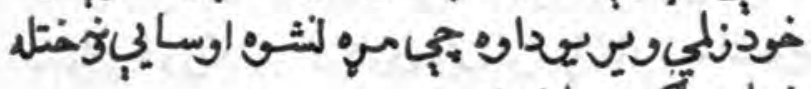

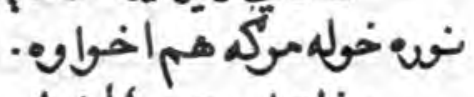

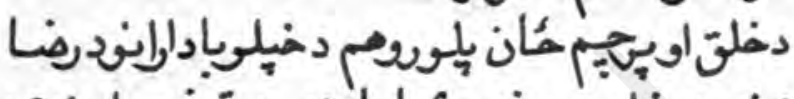

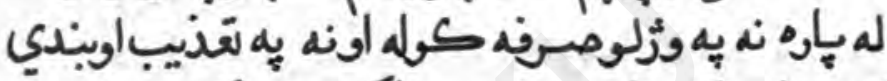

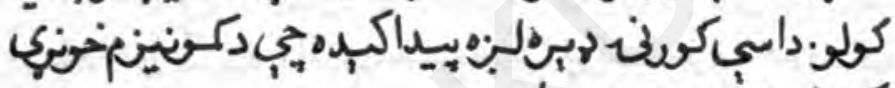

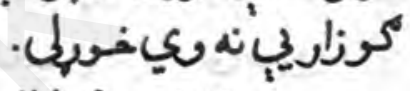

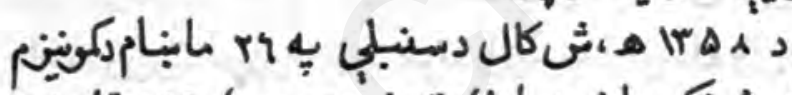

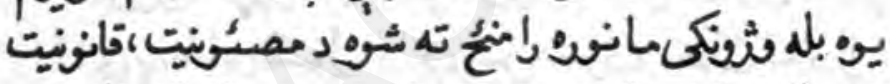

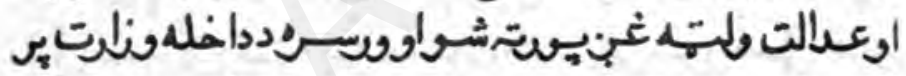

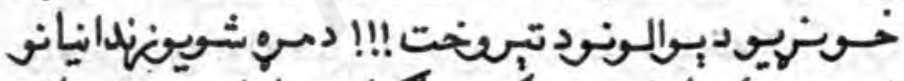

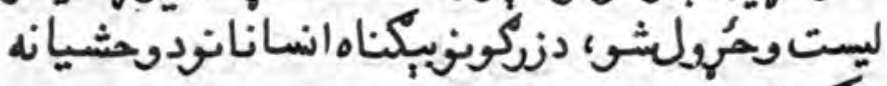

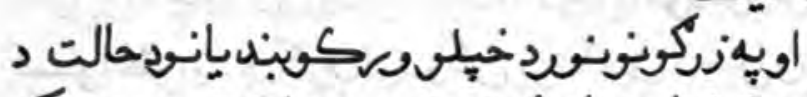
مكرك لميت.

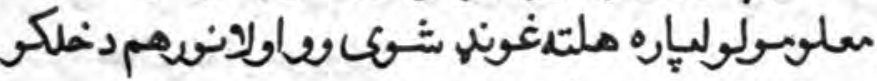

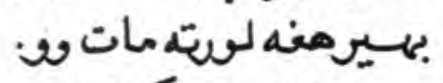

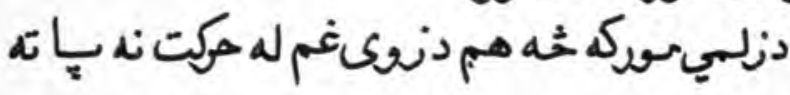




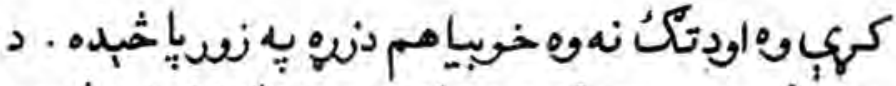

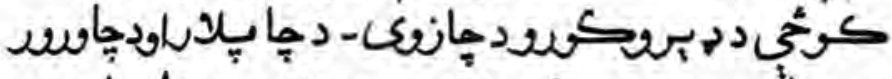

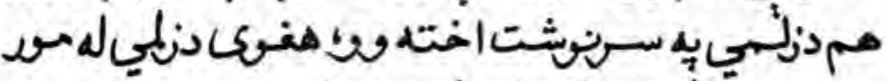

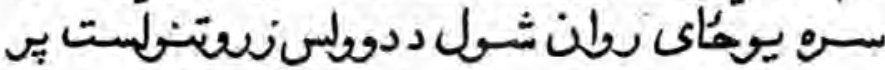

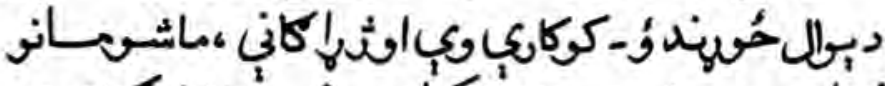

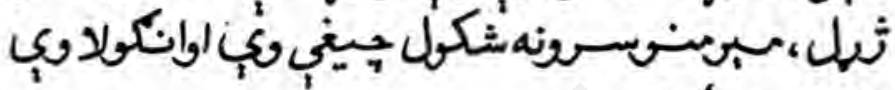

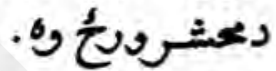

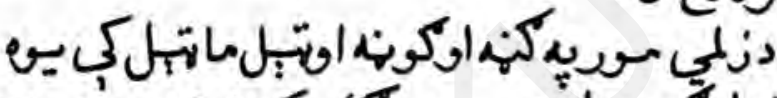

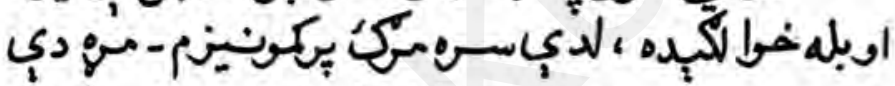

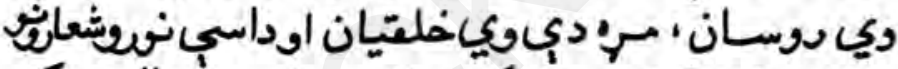

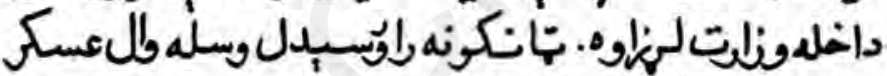

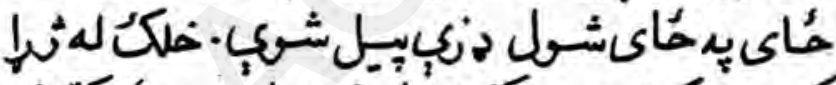

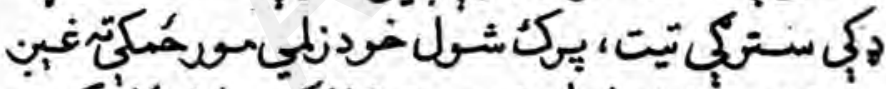

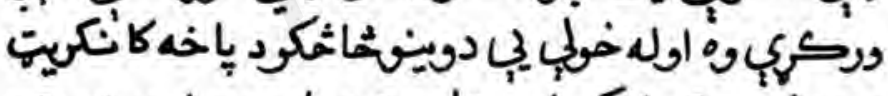

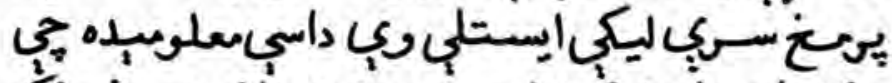

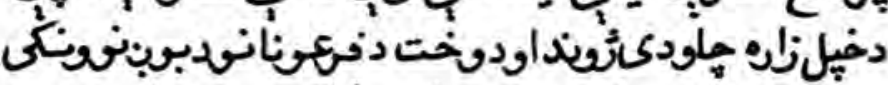

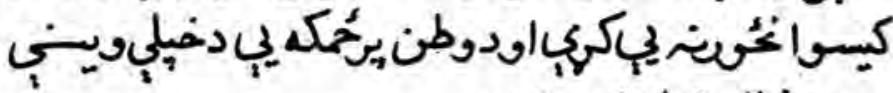

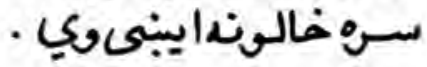


$\left(\begin{array}{c}{ }^{\circ E R T} \\ \text { ACKU } \\ 5675\end{array}\right.$

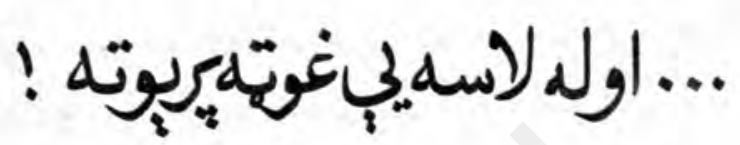

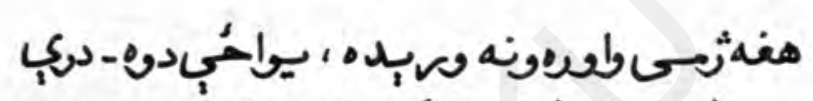

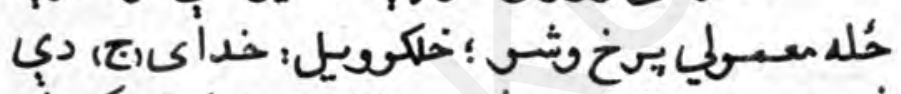

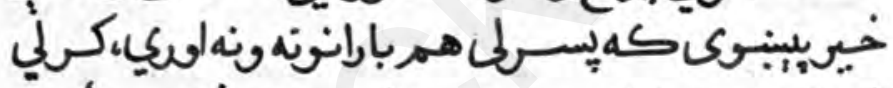

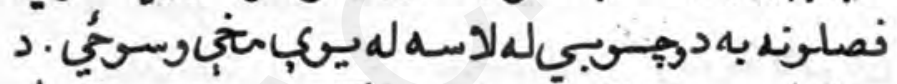

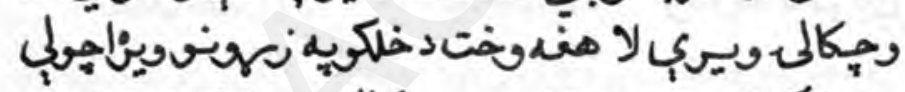

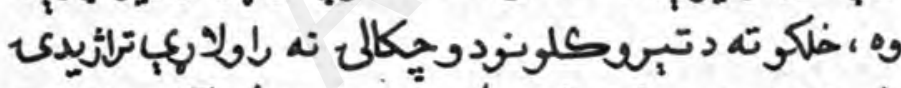

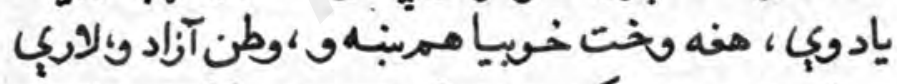

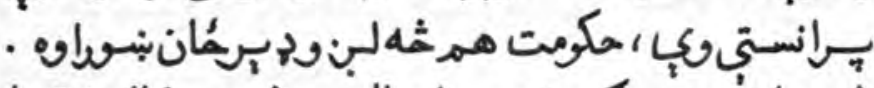

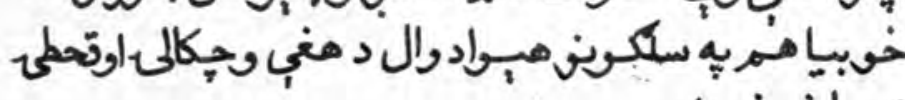

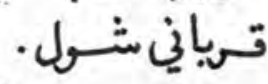

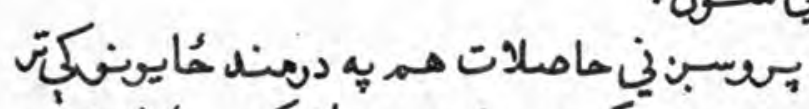

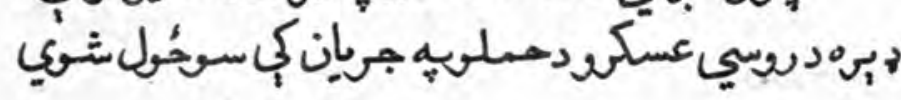

rq 


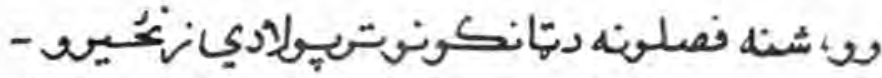

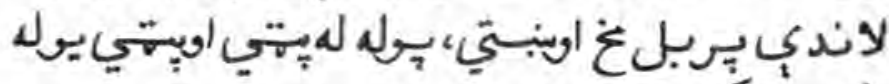

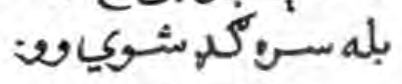

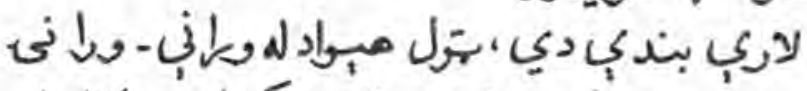

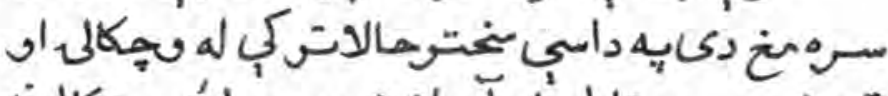

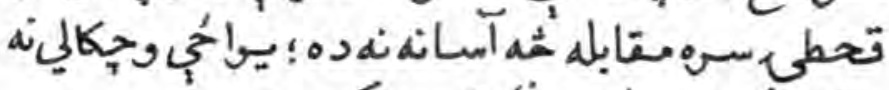

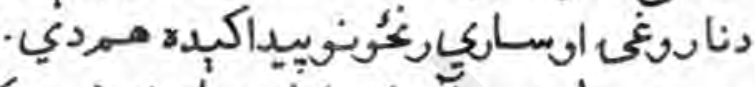

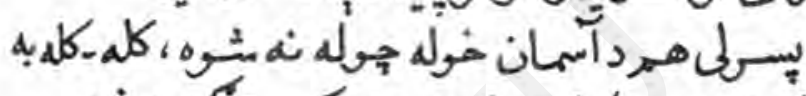

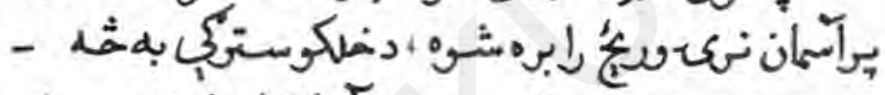

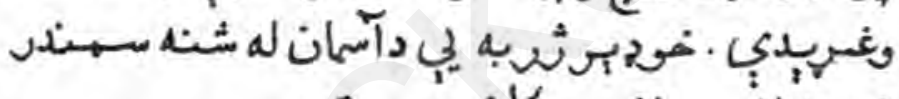

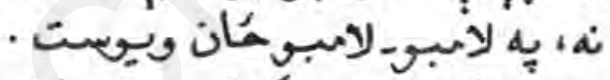

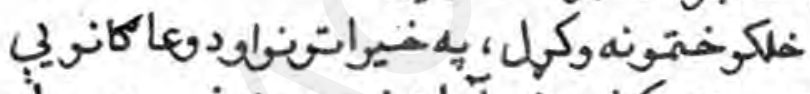

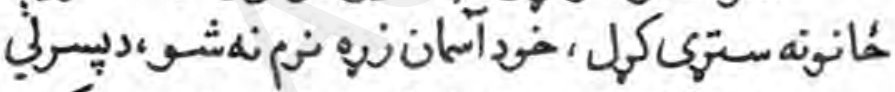

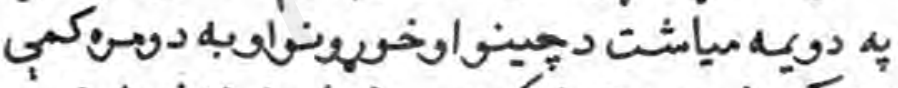

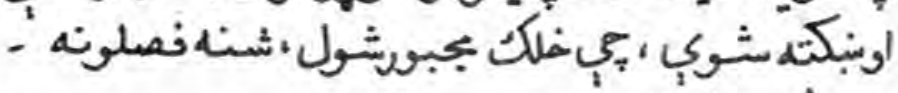

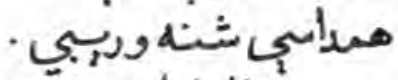

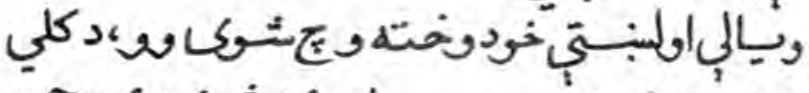

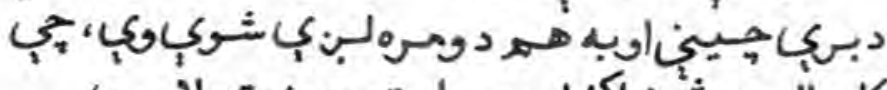

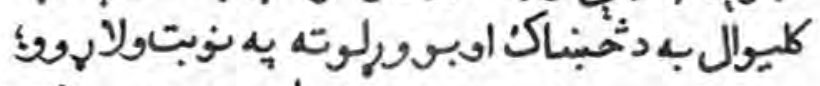

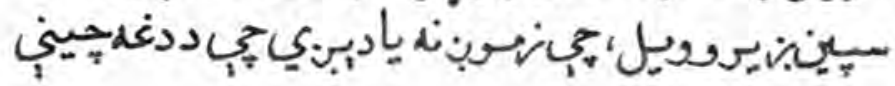




$$
\text { اوبل }
$$

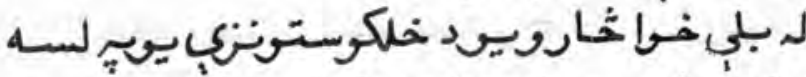

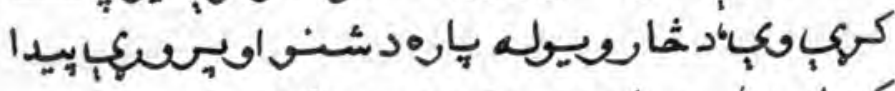

$$
\text { كيال تصل }
$$

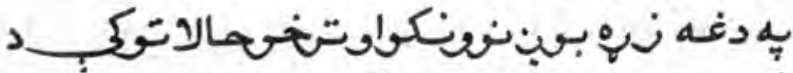

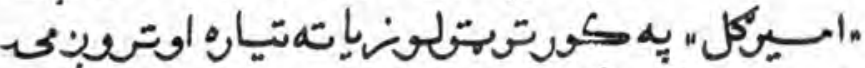

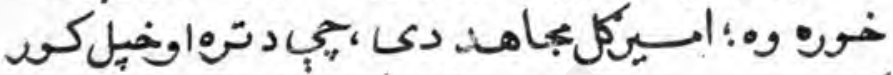

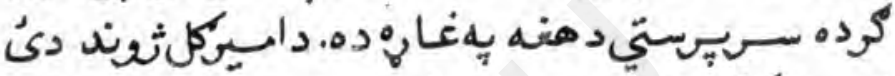

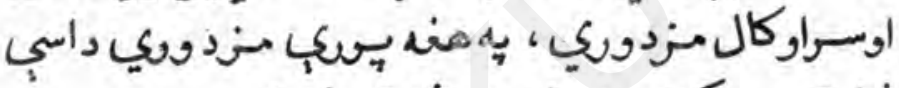

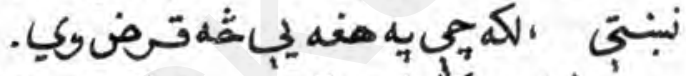

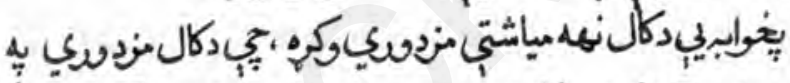

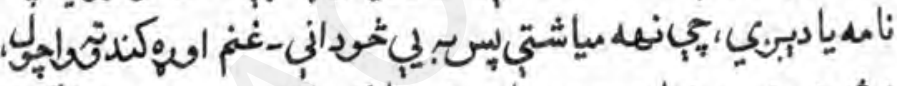

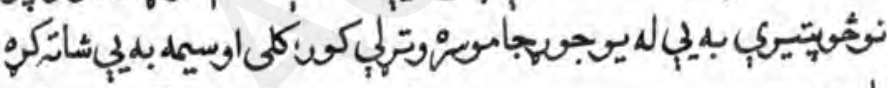

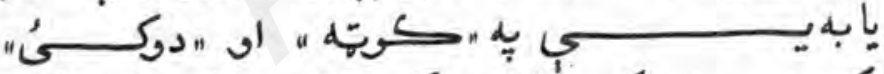

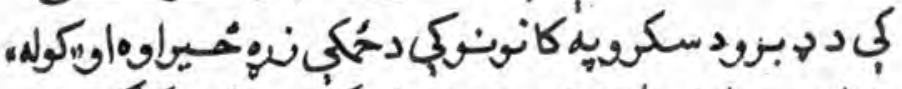

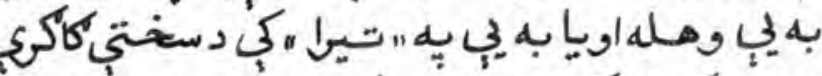

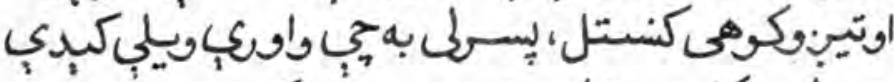

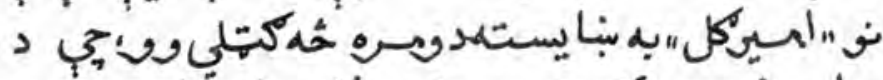

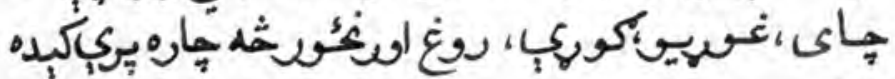
اولاد مله به 


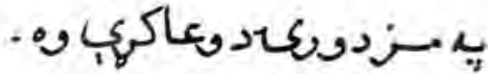

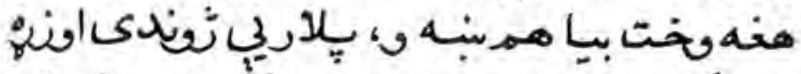

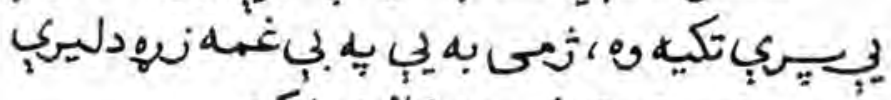

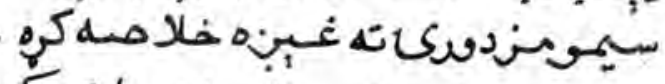

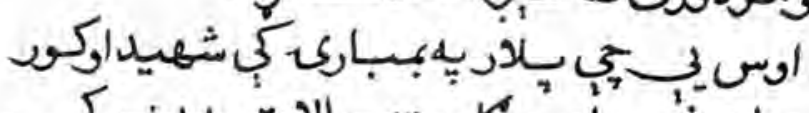

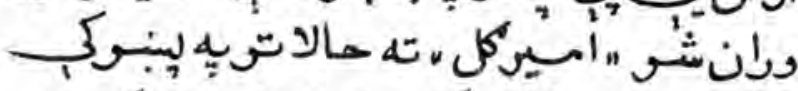

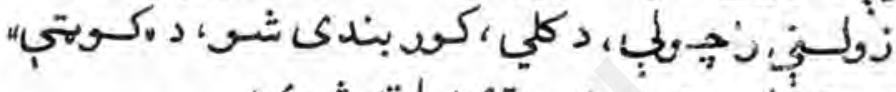

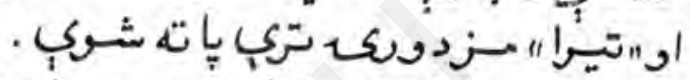

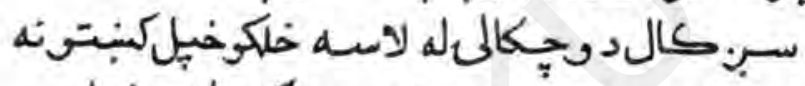

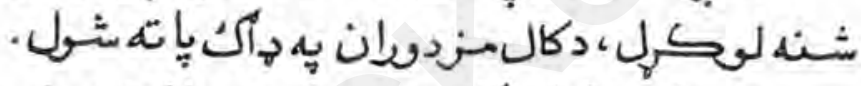

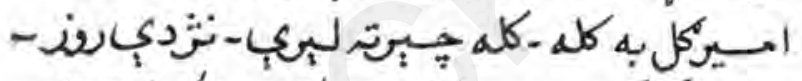

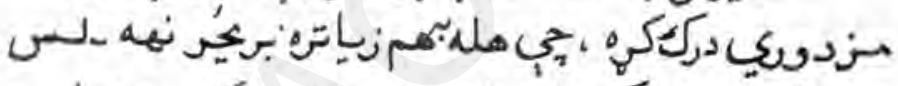

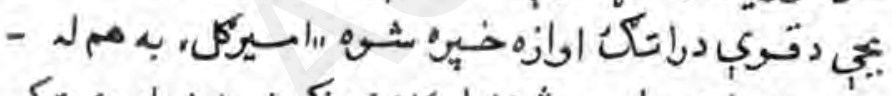

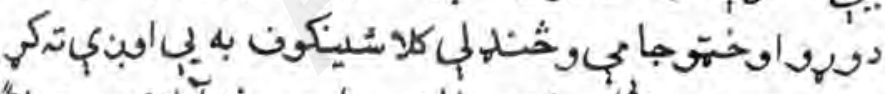

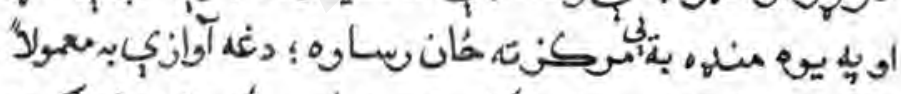

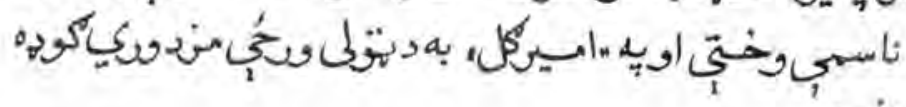

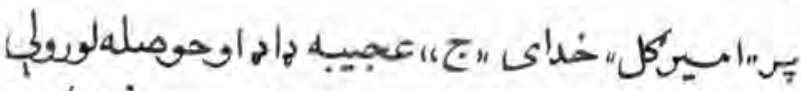

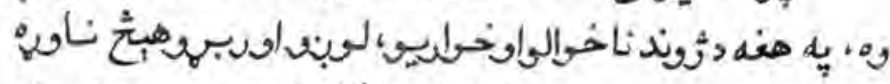

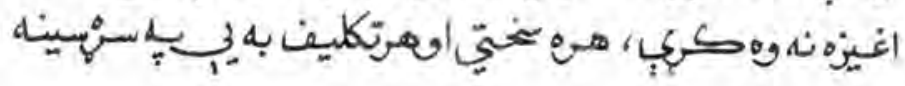




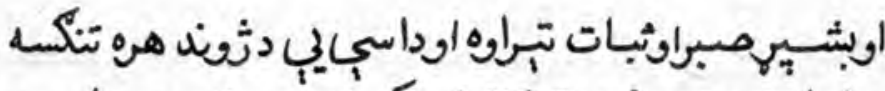

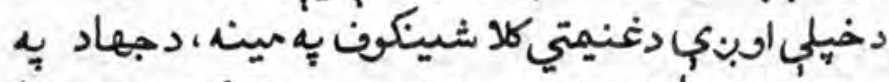

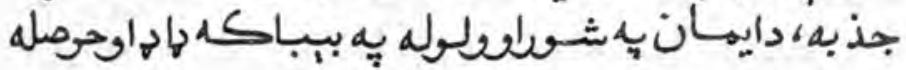
تبعله

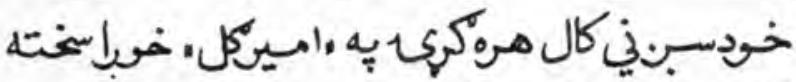

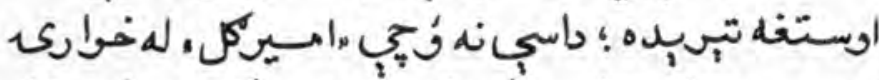

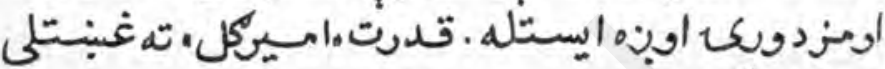

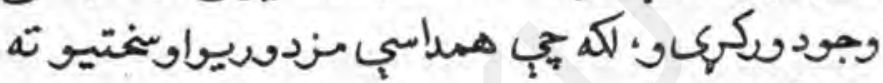
جوريثىعي.

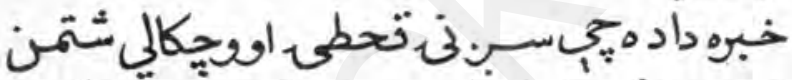

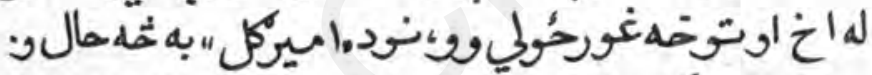

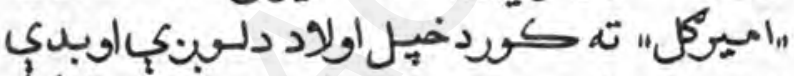

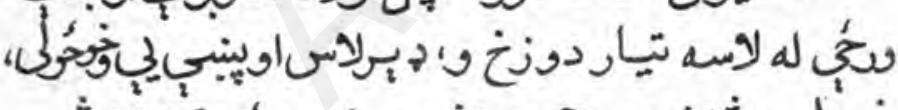

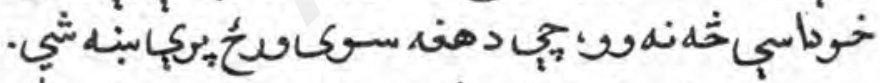

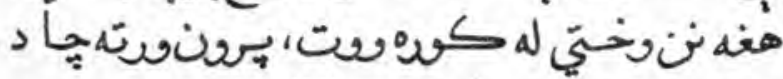

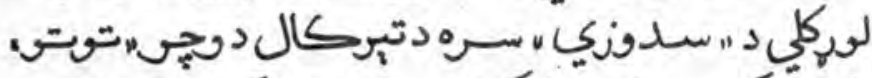

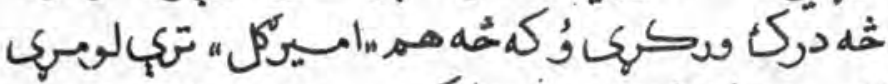

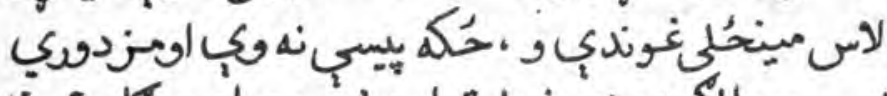

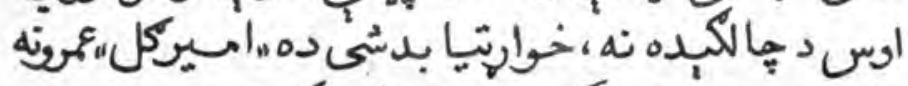

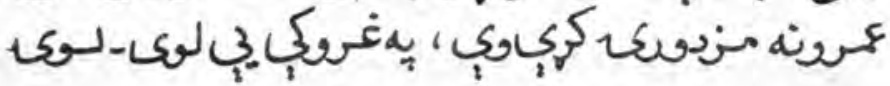




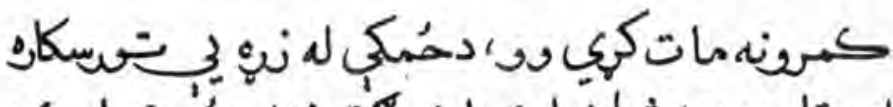

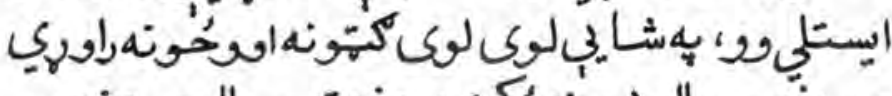

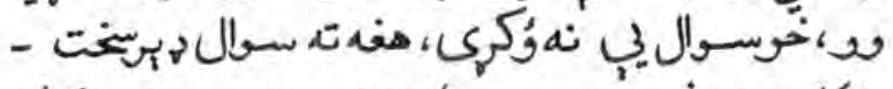

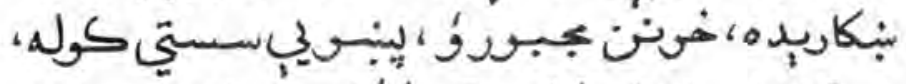

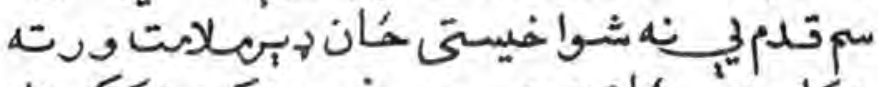

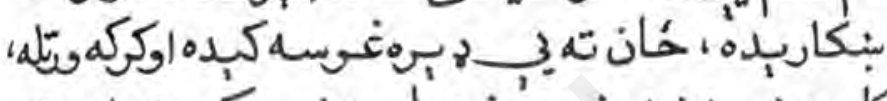

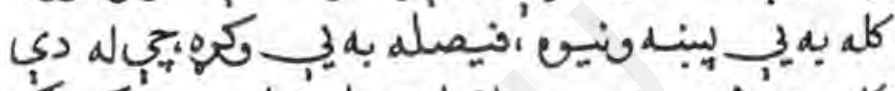

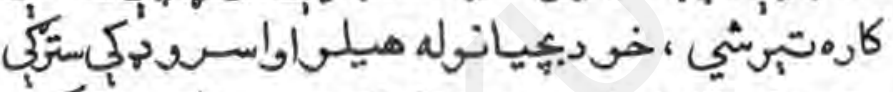

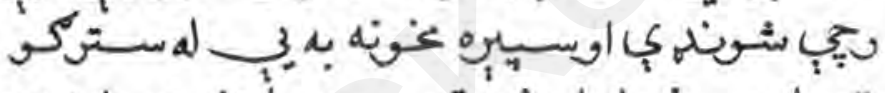

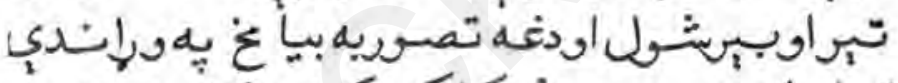

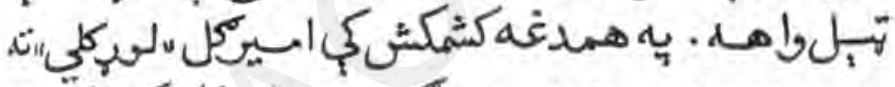

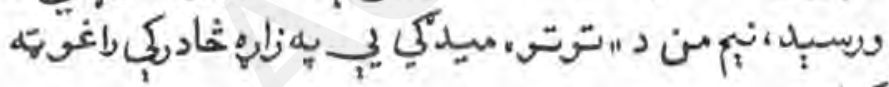
كريل.

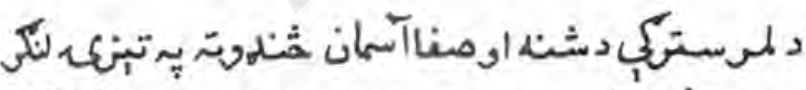

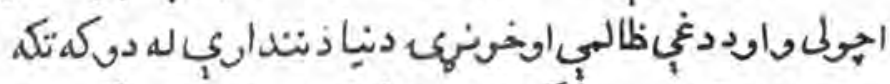

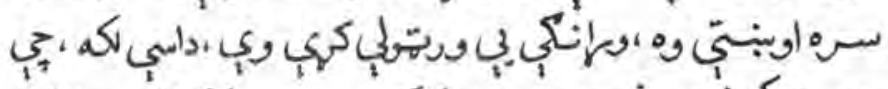

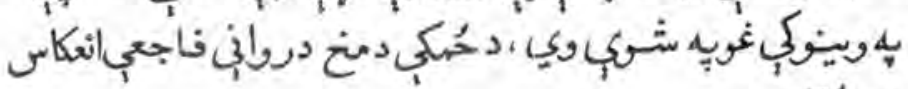

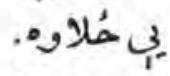

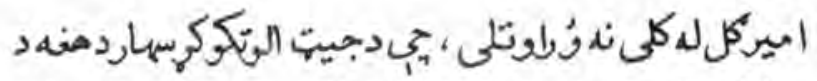

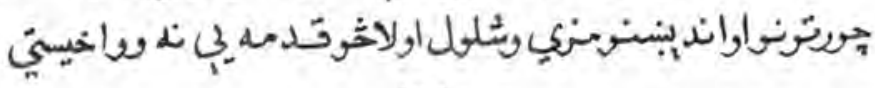
r $\varepsilon$ 


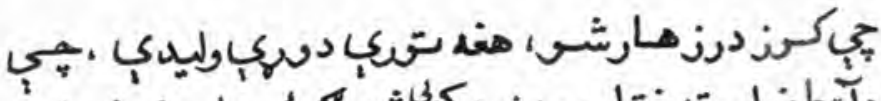

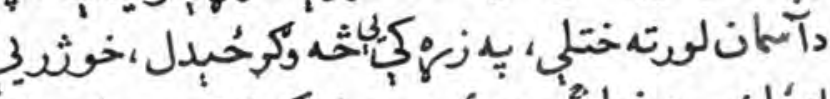

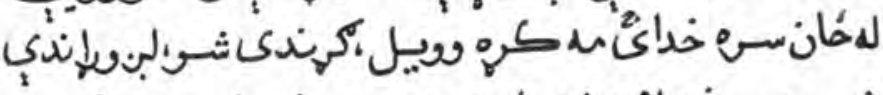

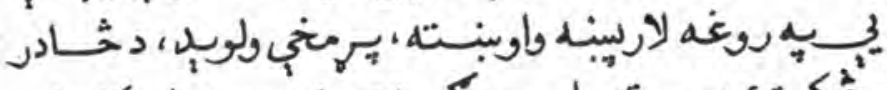

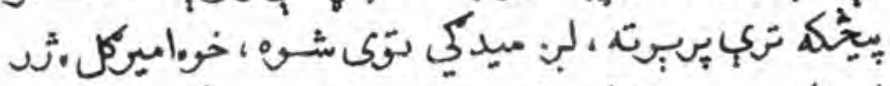

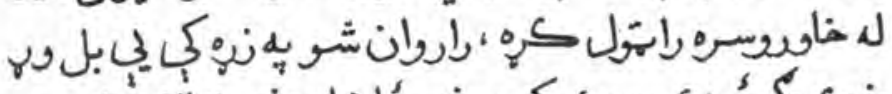

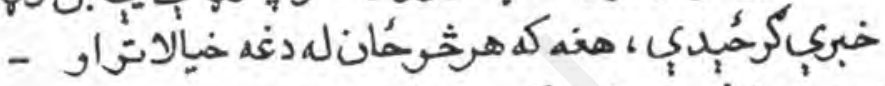

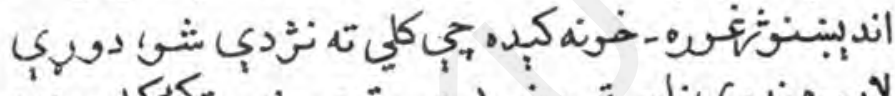

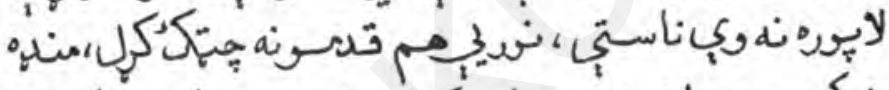

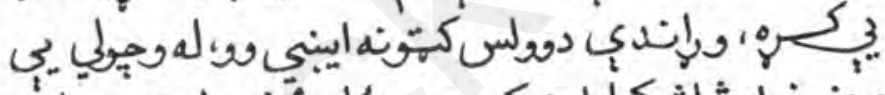

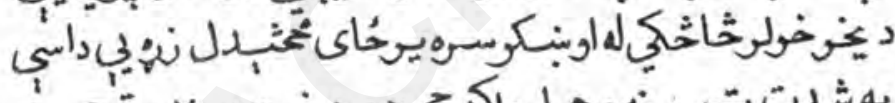

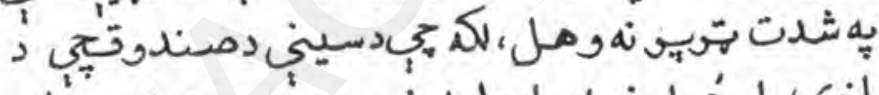

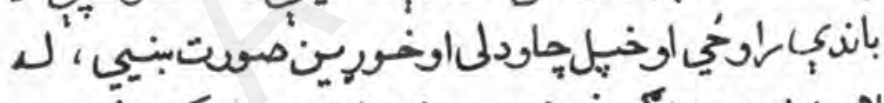

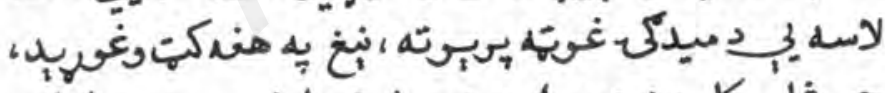

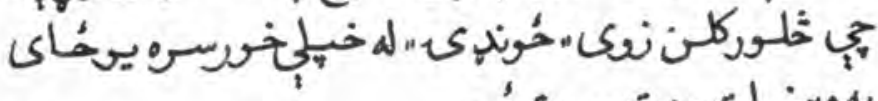

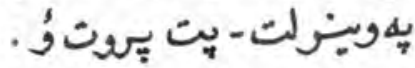


pe 


\section{قككانهيوال}

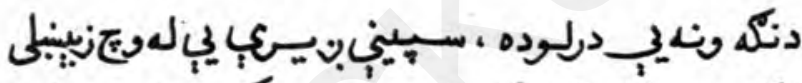

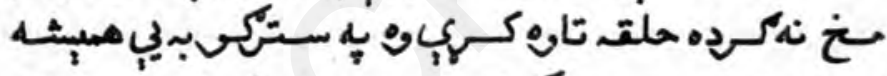

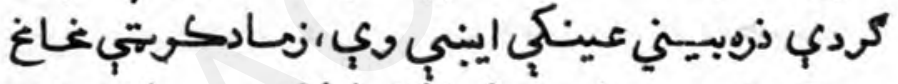

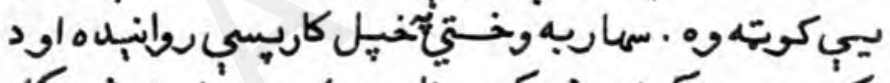

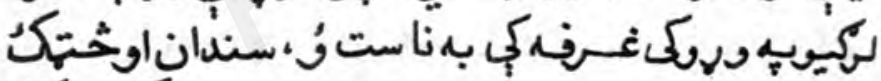

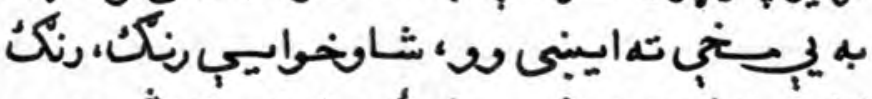

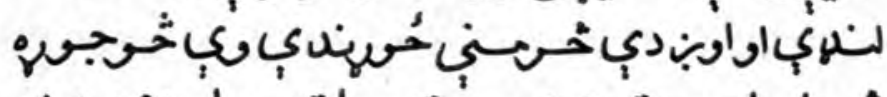

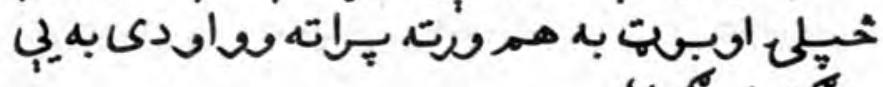

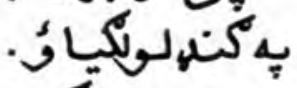

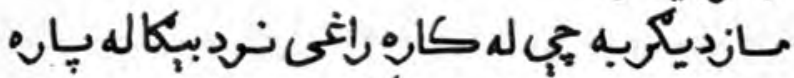

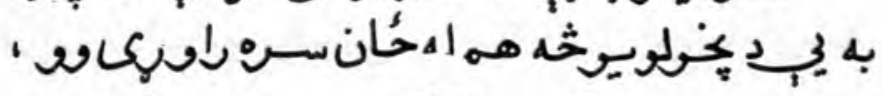
rV 


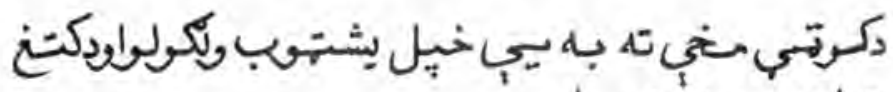

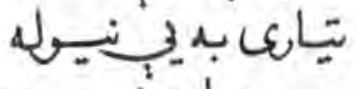

.

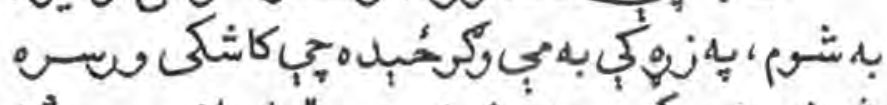

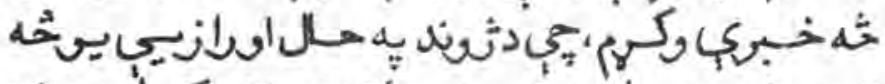

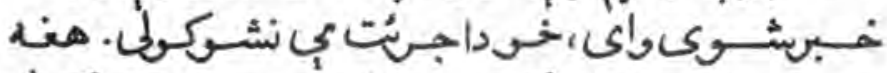

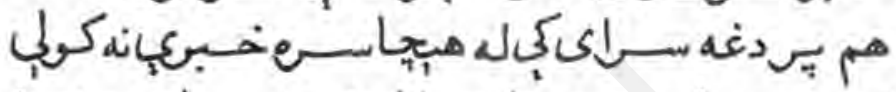

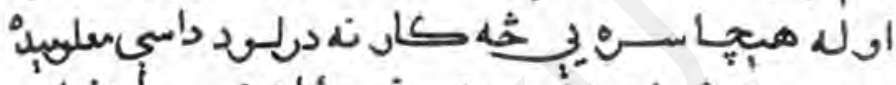

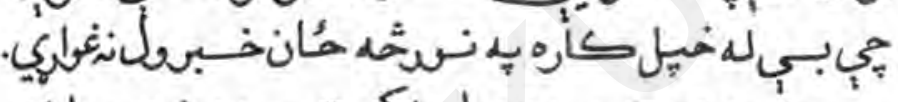

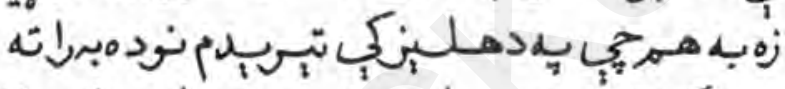

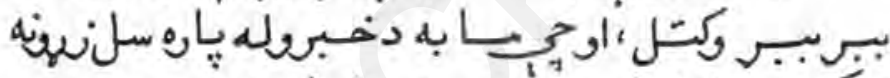

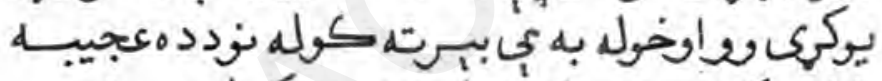

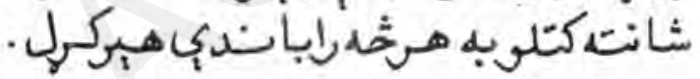

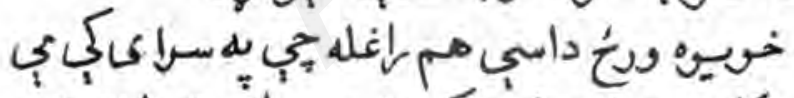

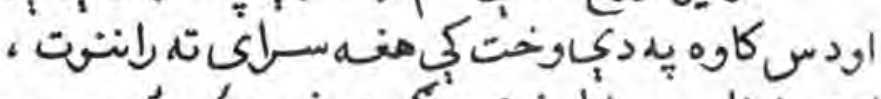

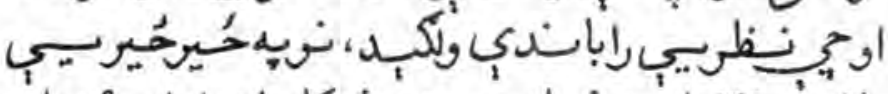

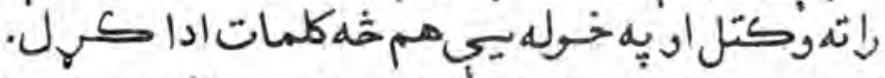

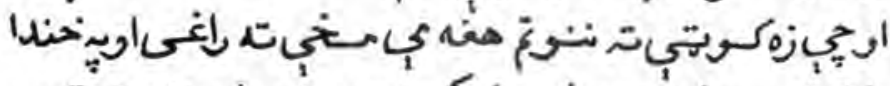

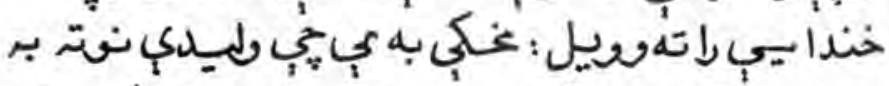

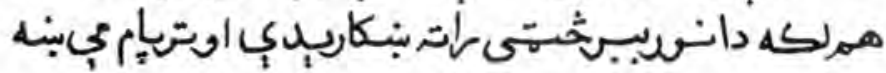




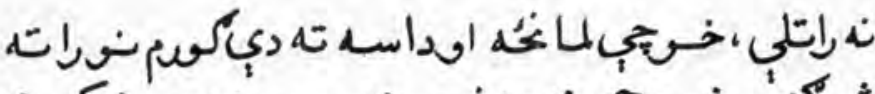

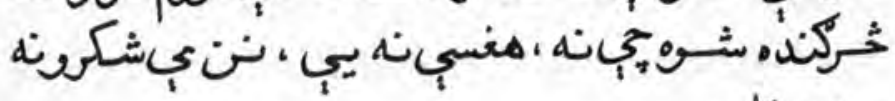

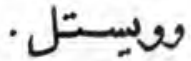

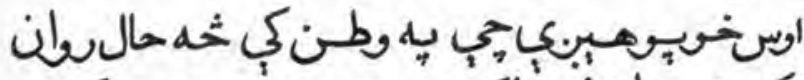

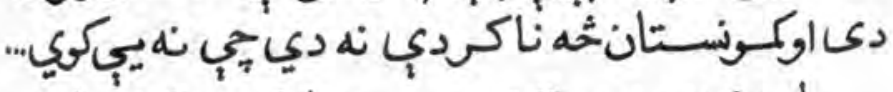

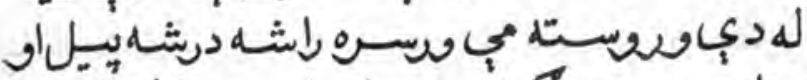

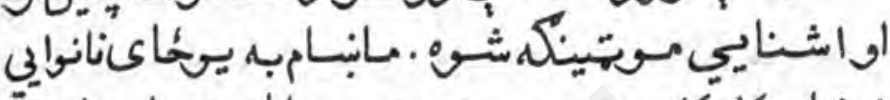

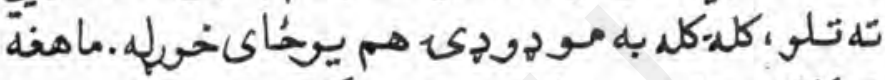

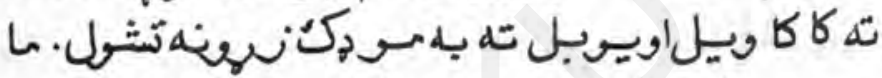

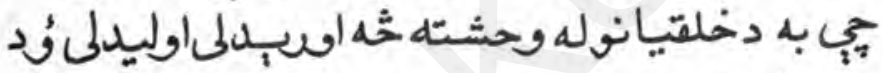

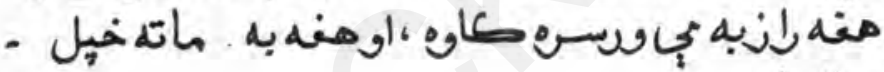
حـالـإيه.

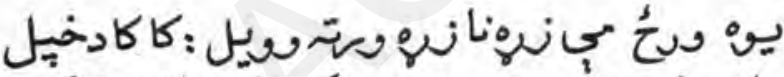

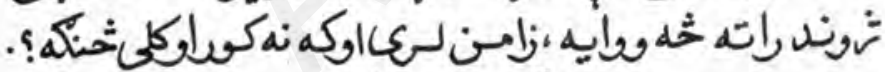

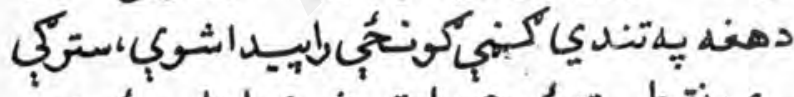

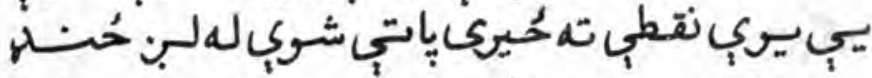

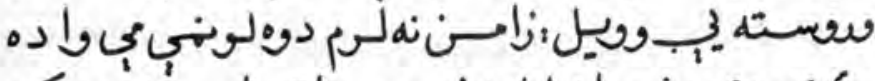

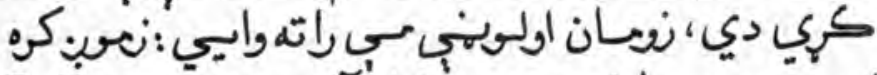

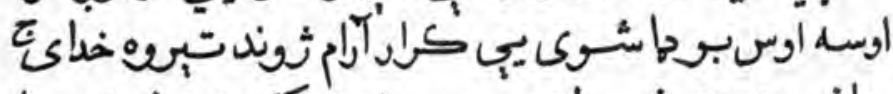

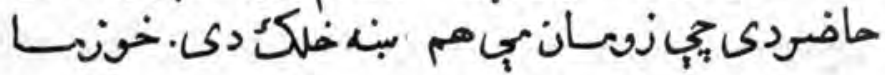




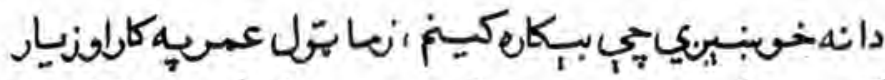

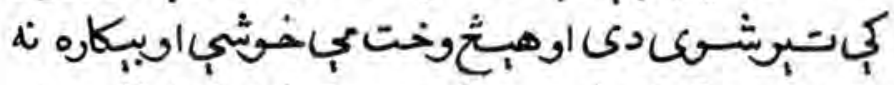

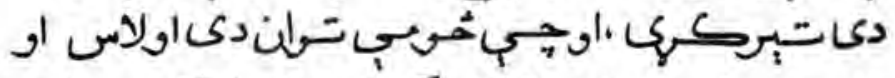

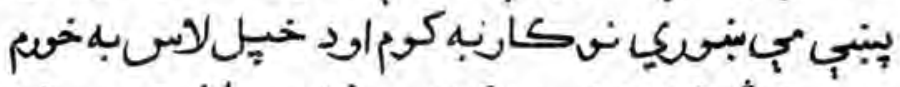

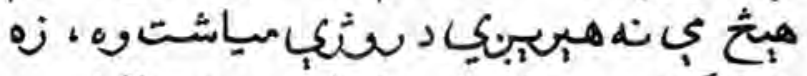

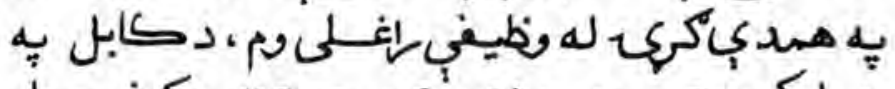

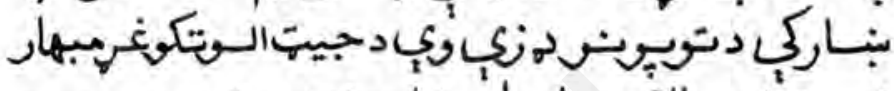

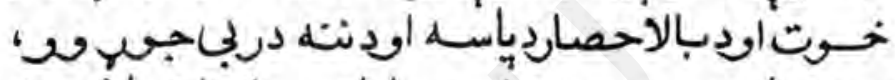

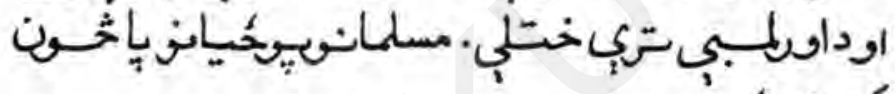

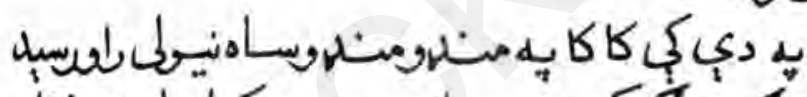

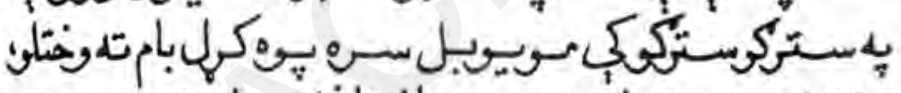

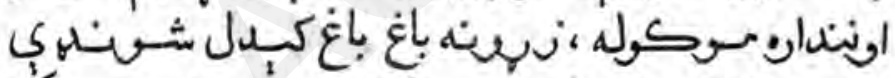

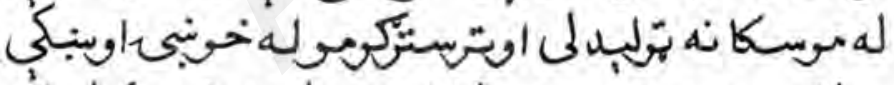

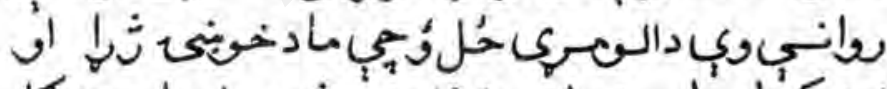

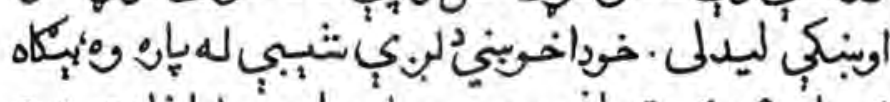

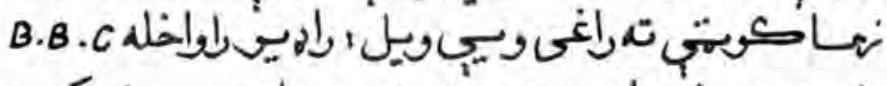

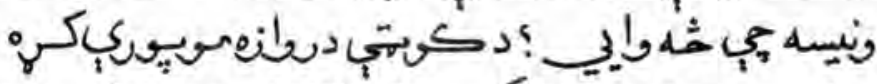

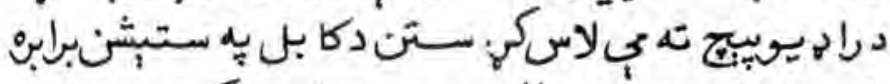

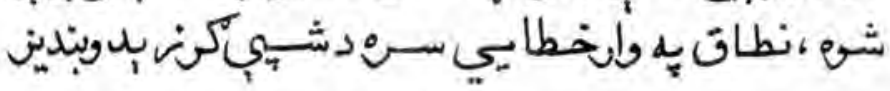




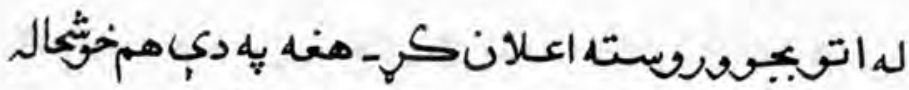

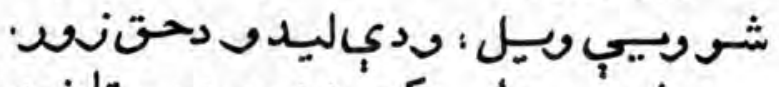

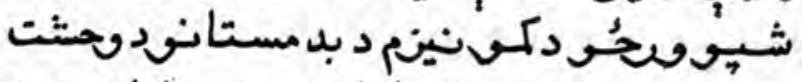

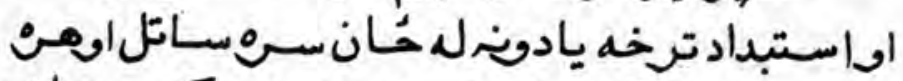

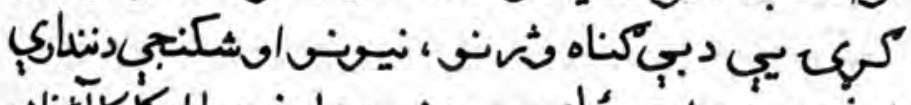

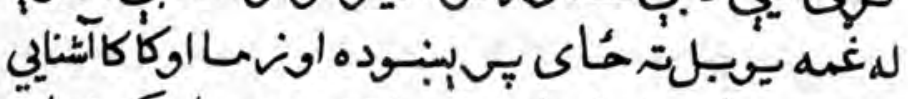

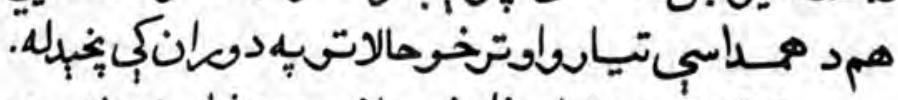

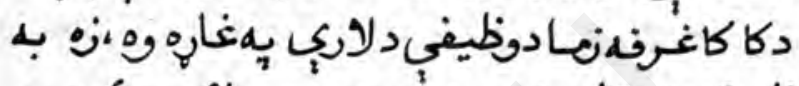

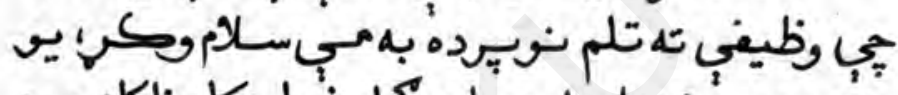

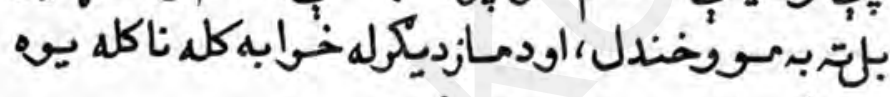

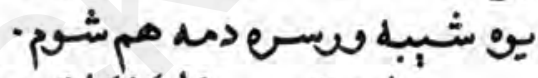

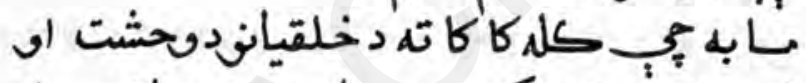

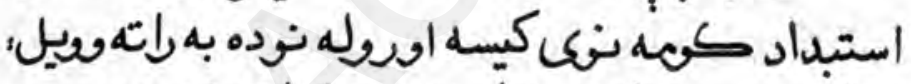

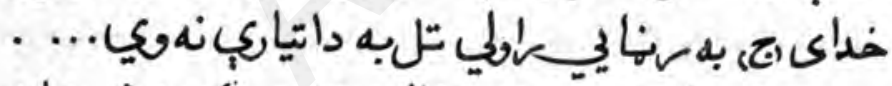

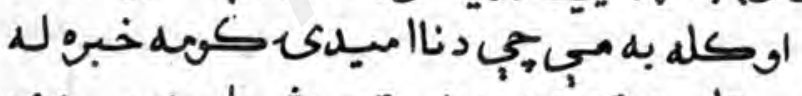

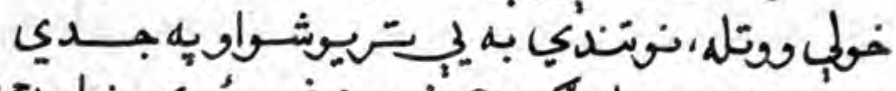

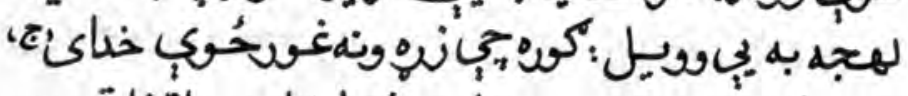

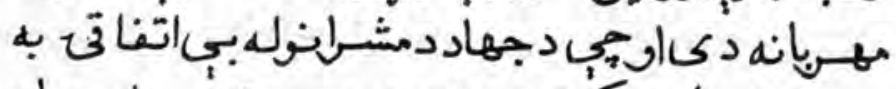

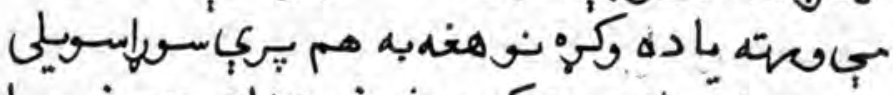

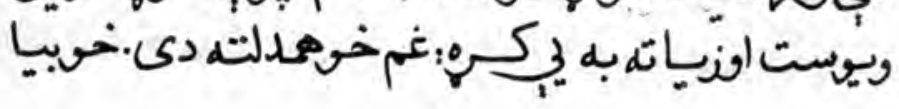




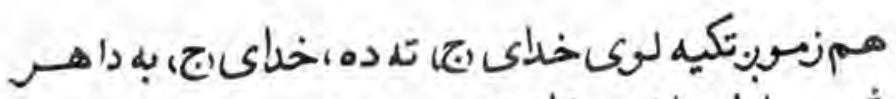

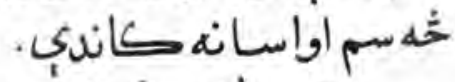

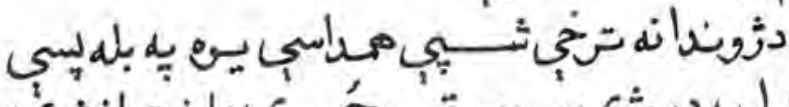

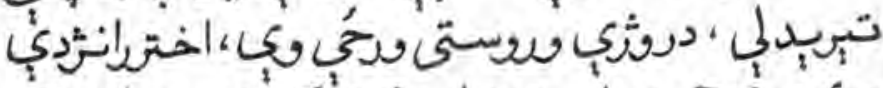

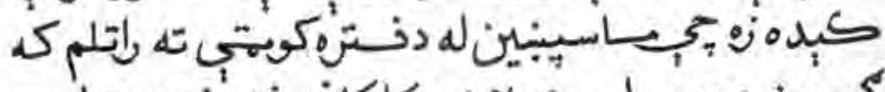

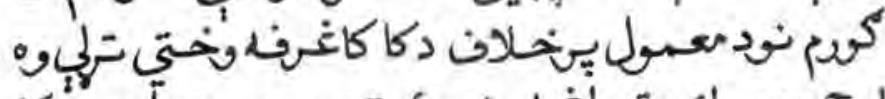

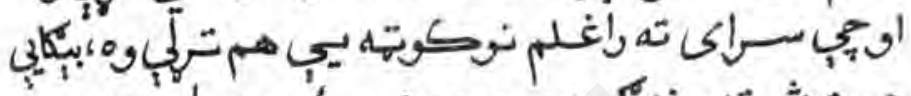

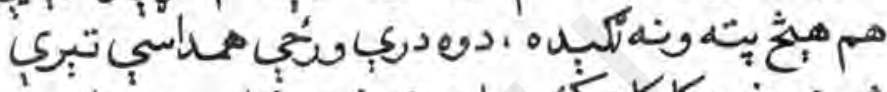

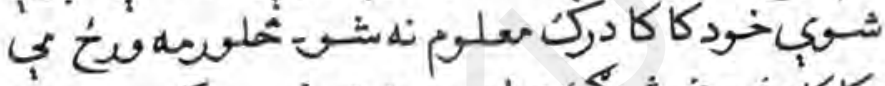

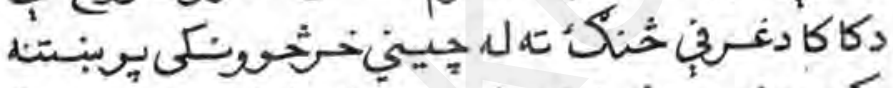

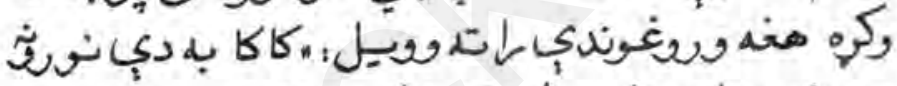

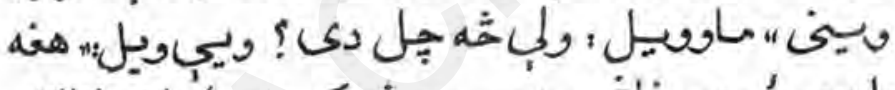

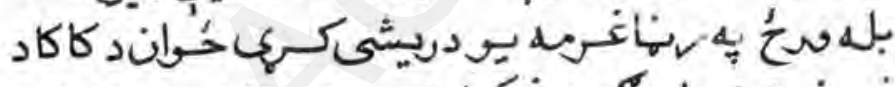

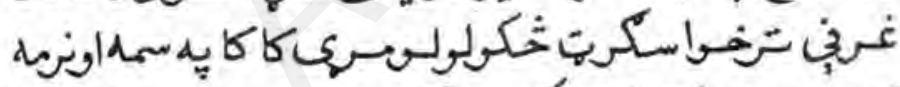

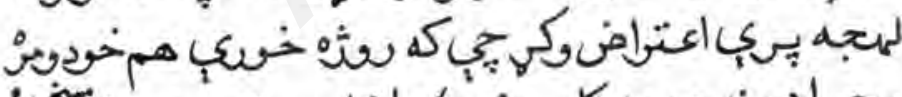

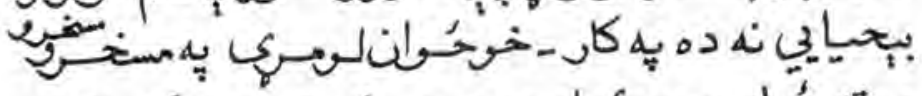

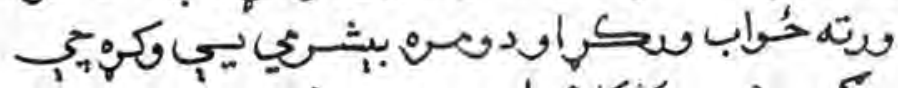

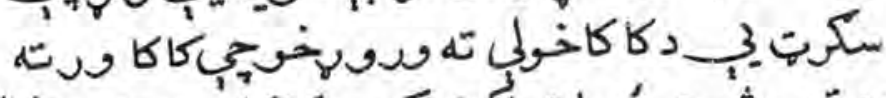

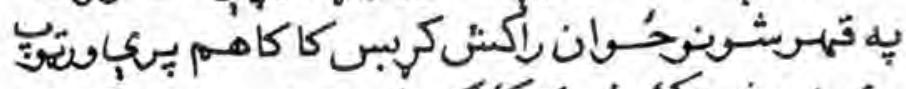

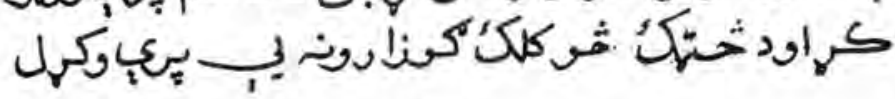




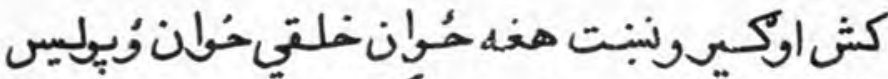

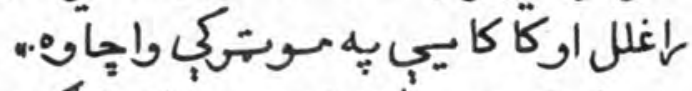

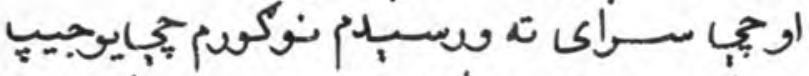

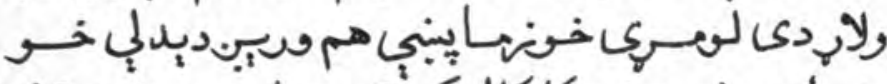

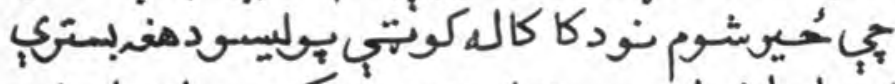

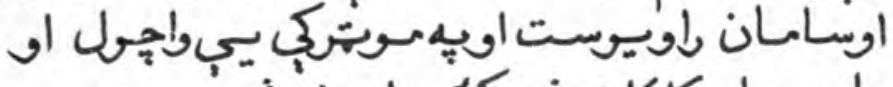

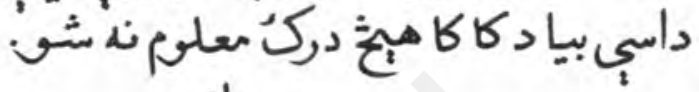
(إِى

$+* *+4$ 
$\varepsilon \varepsilon$ 


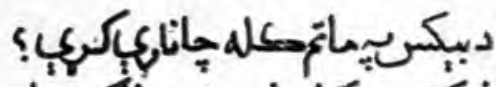

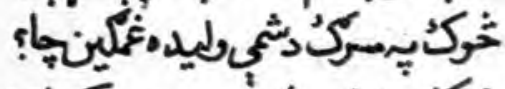

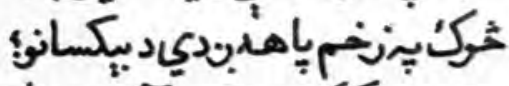

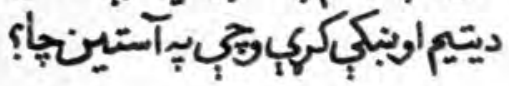

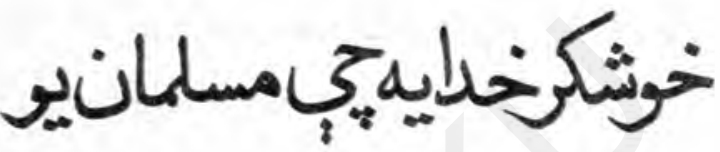

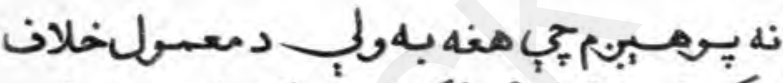

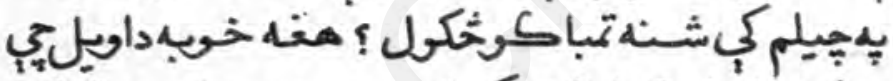

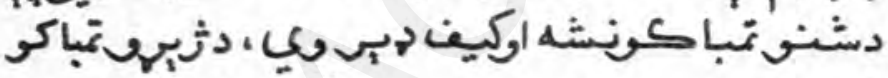

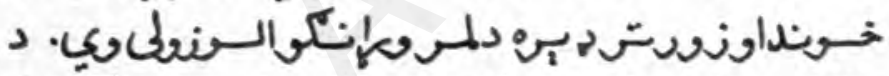

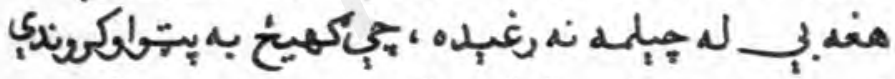

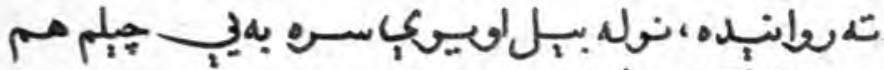

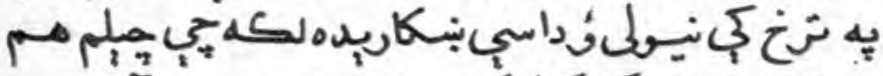

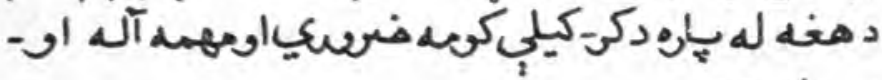

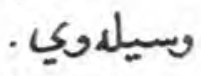

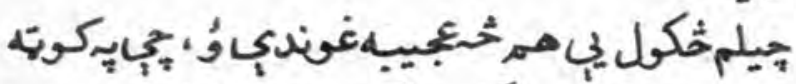

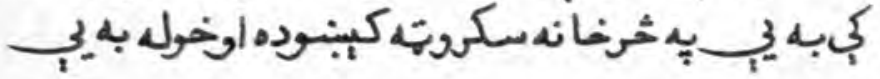




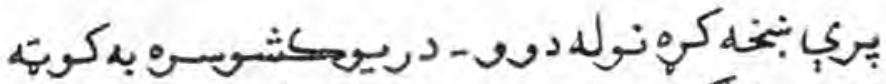

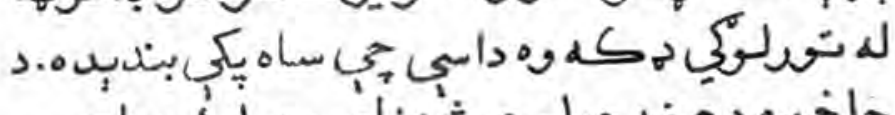

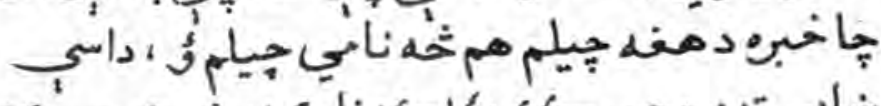

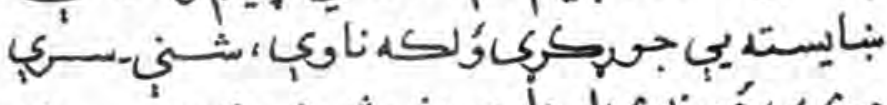

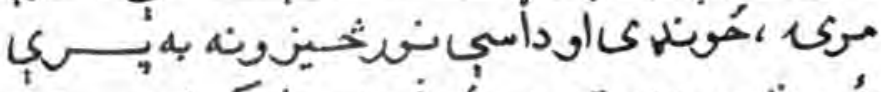

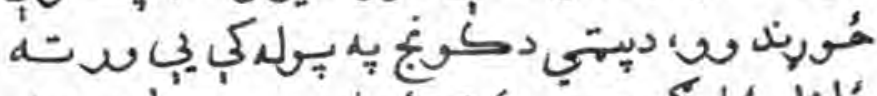

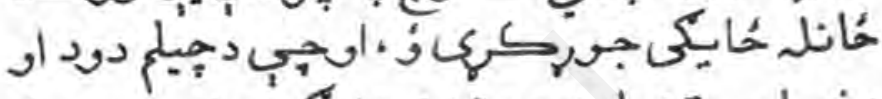

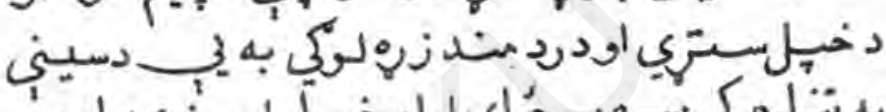

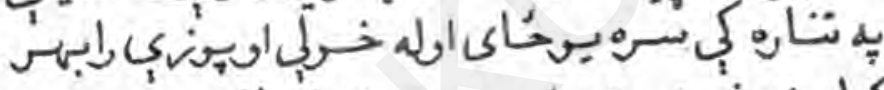

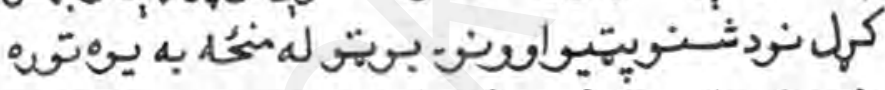

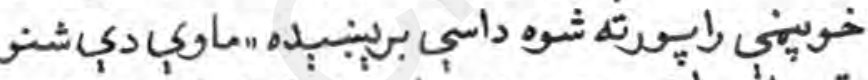

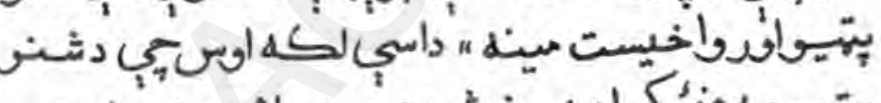

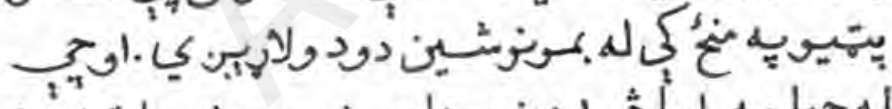

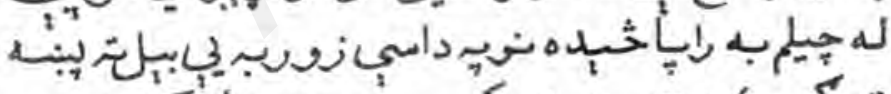

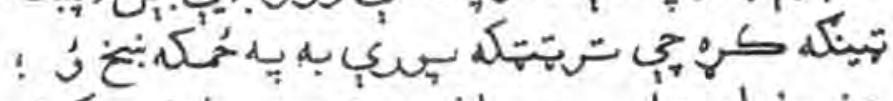

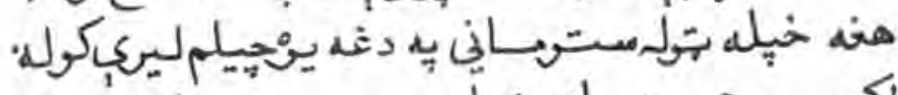

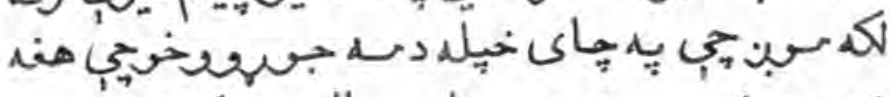

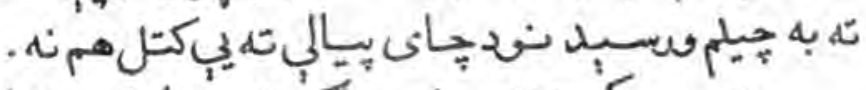

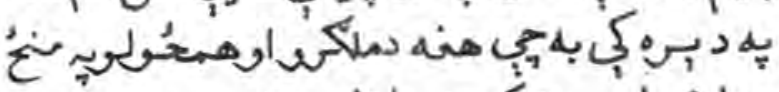

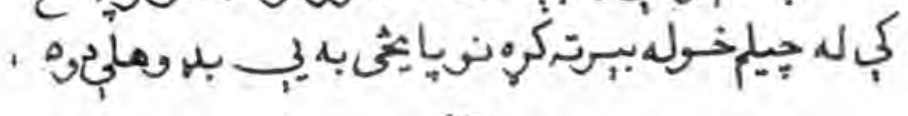




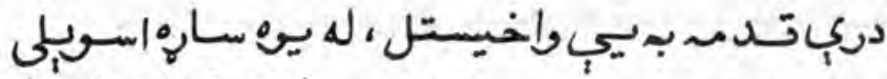

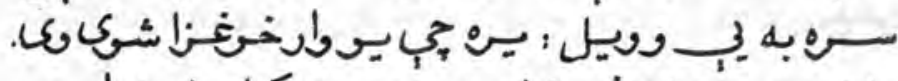

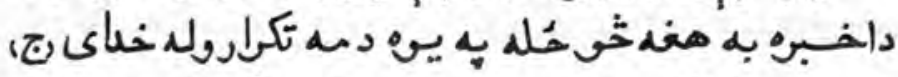

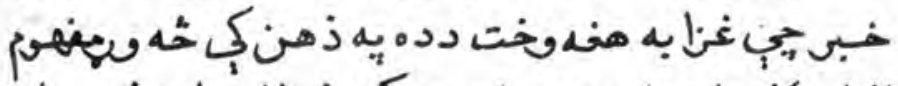

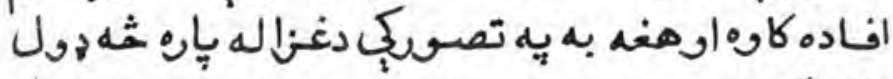

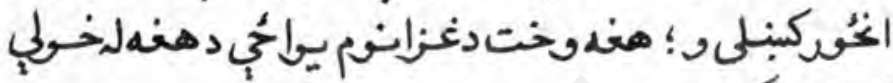

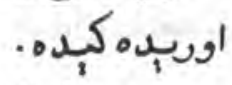

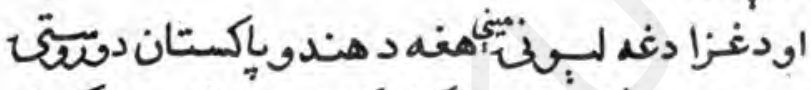

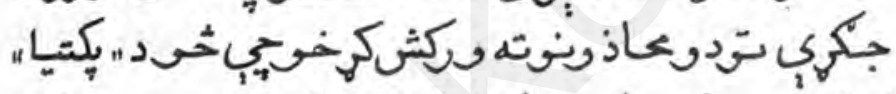

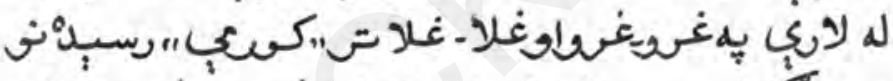

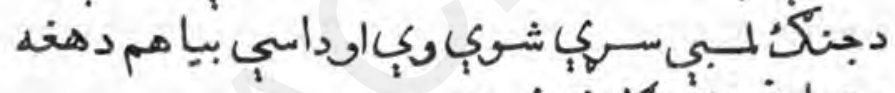

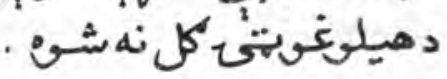

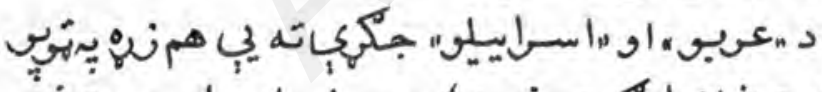

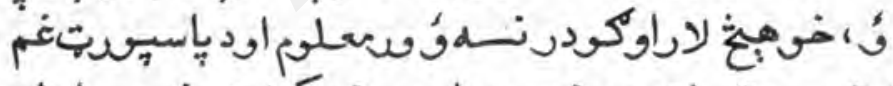

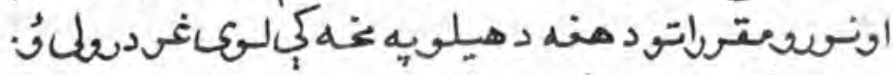

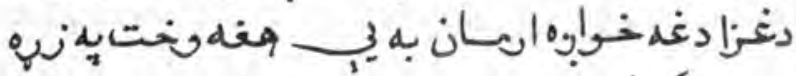

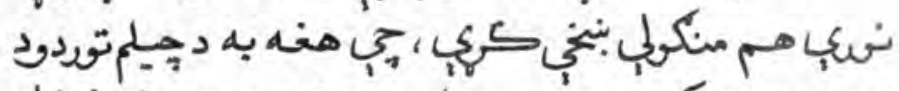

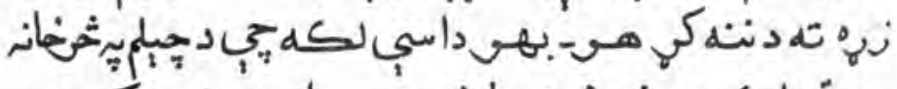

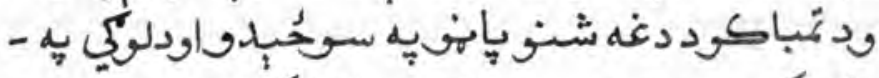

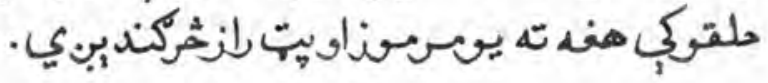




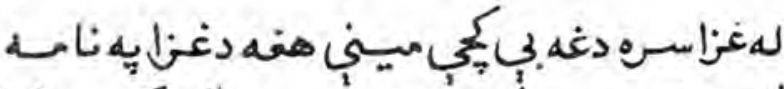

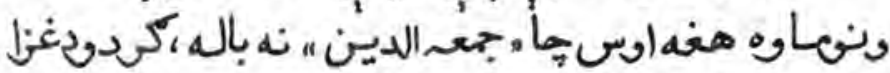

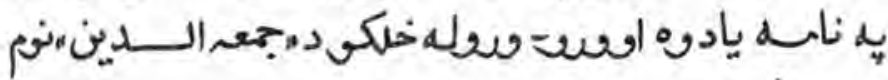

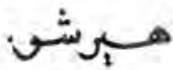

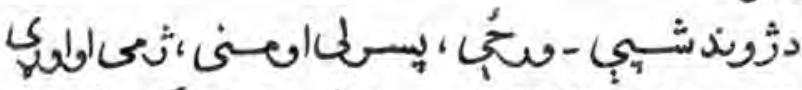

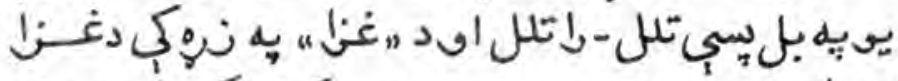

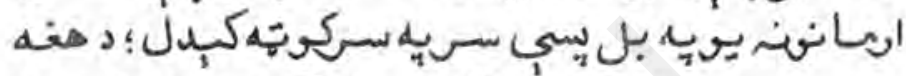

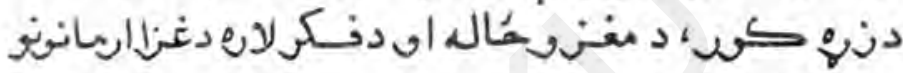
O

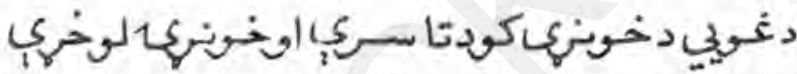

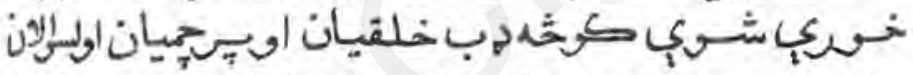

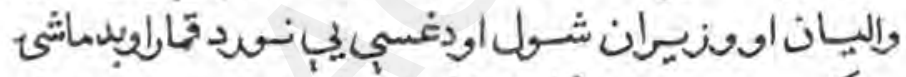

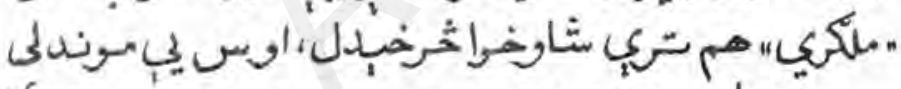

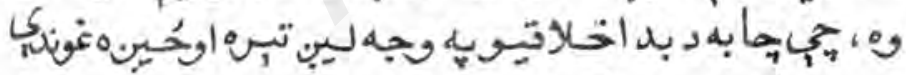

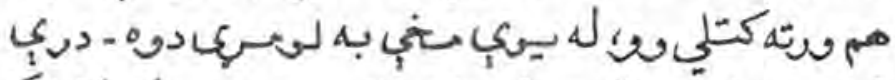

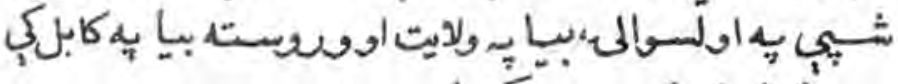

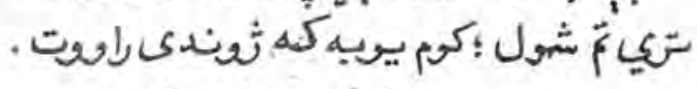

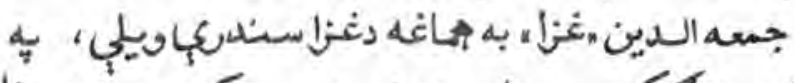

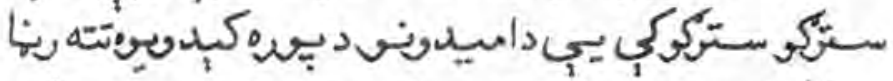

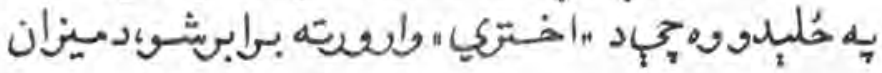




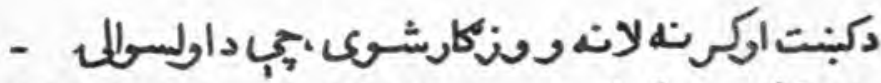

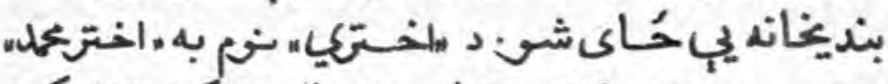

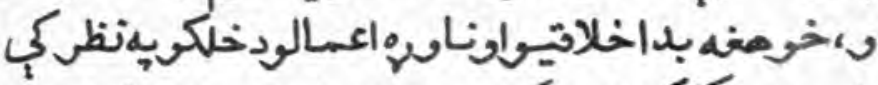

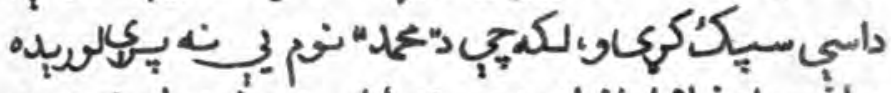

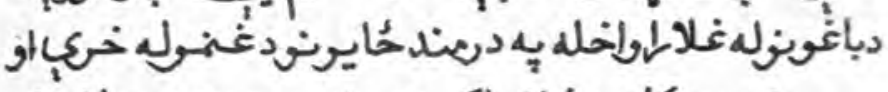

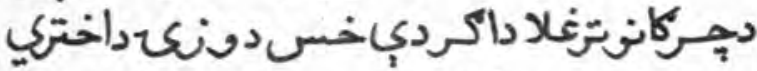

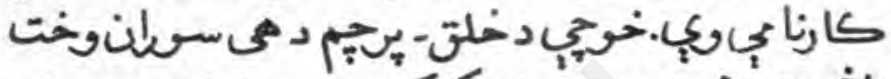

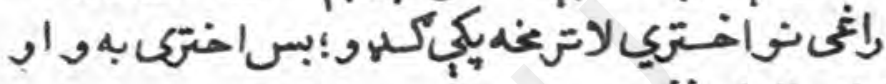

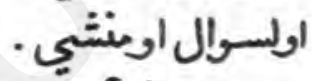

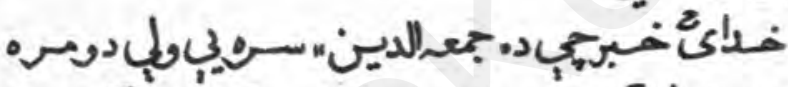

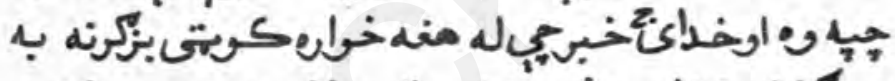

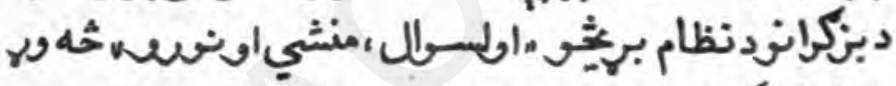

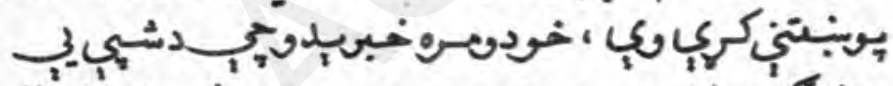

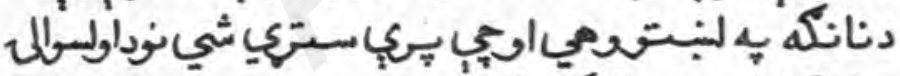

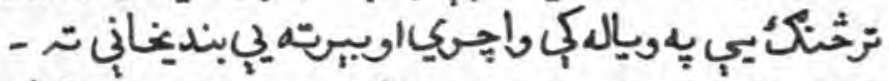

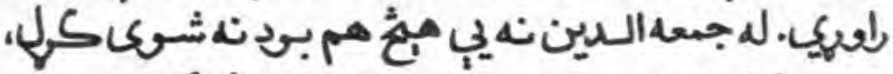

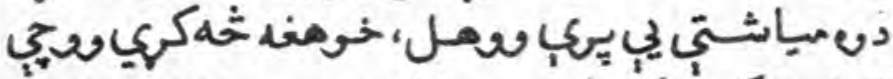

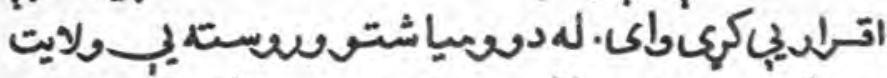

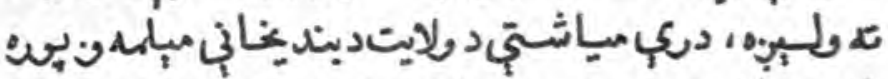

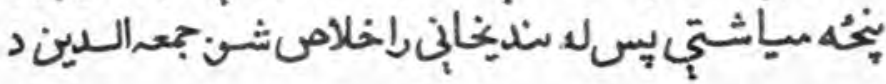
\&9 


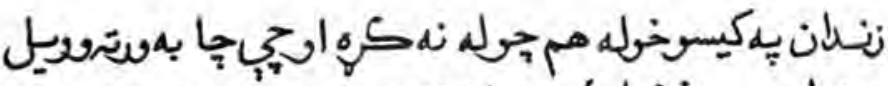

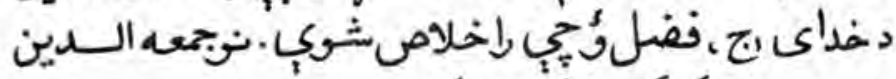

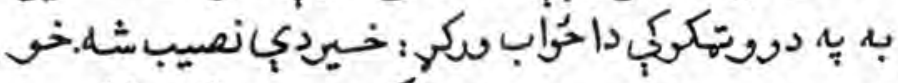

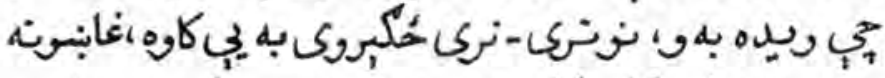

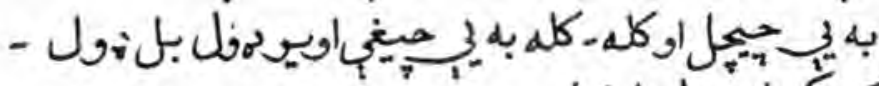

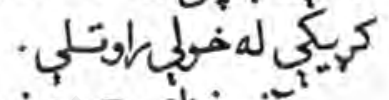

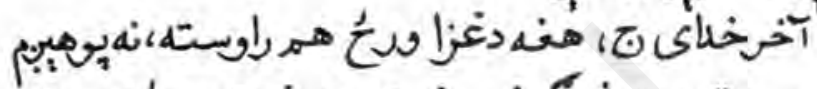

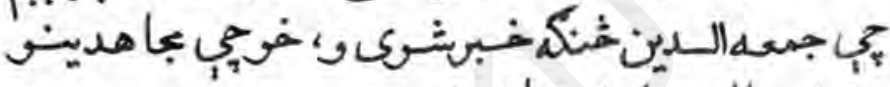

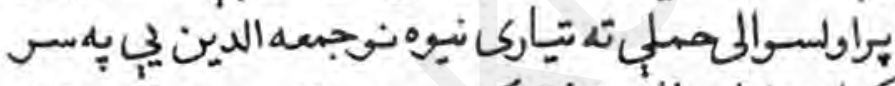

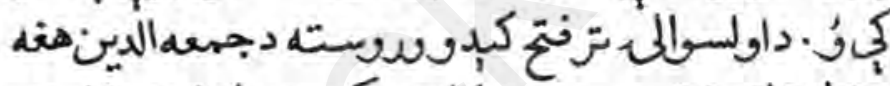

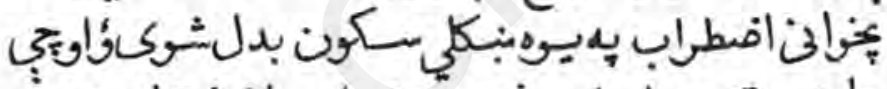

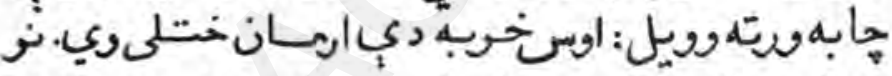

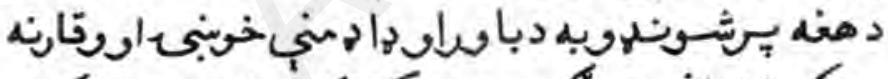

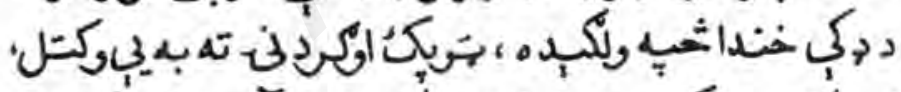

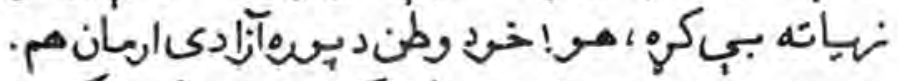

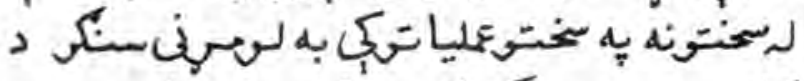

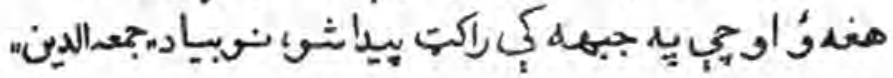
مياوبنهو $+\quad+$

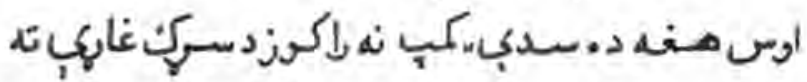
o. 


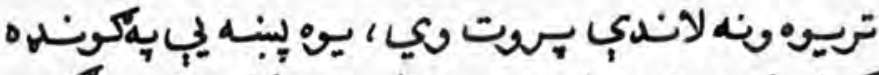

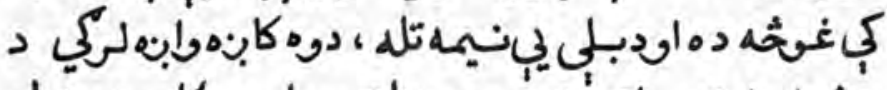

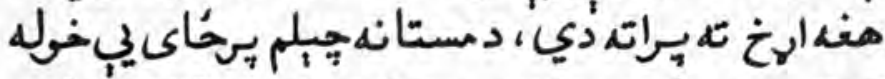

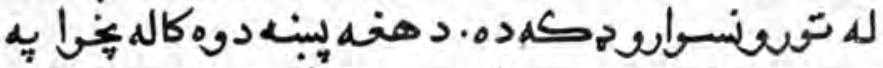

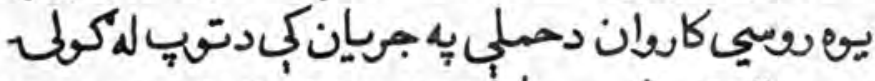

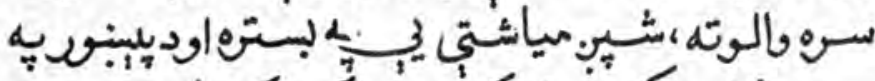

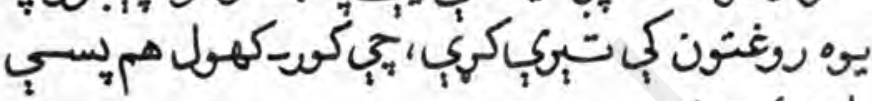

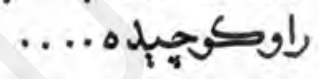

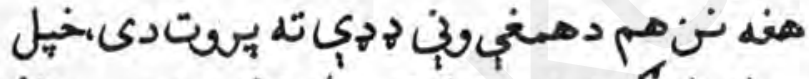

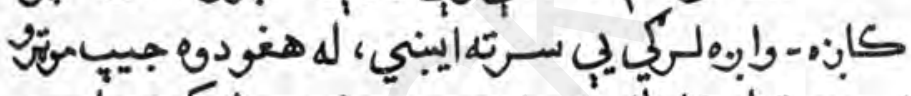

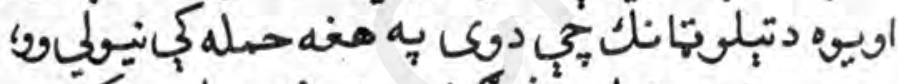

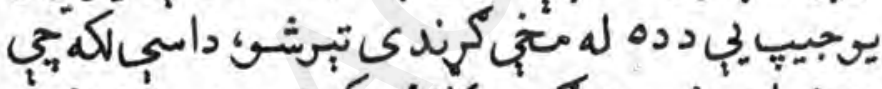

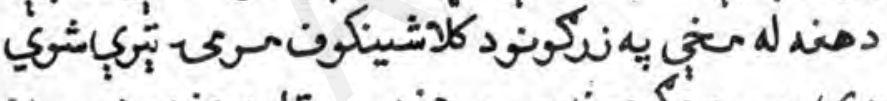

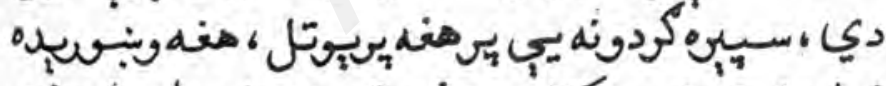

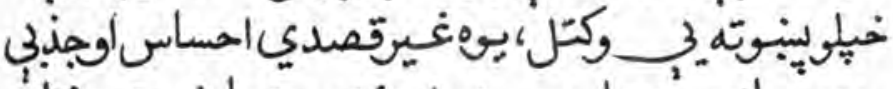

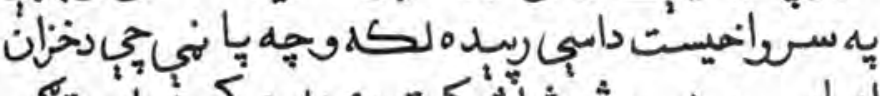

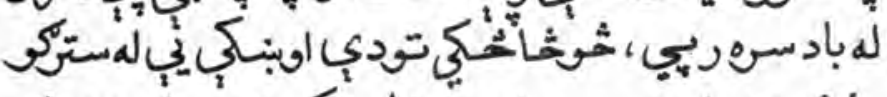

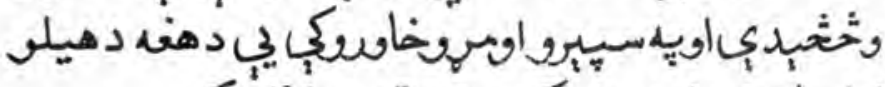

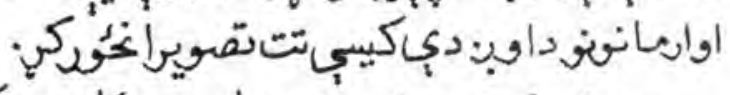

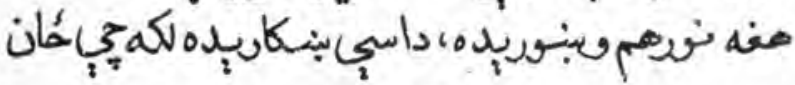




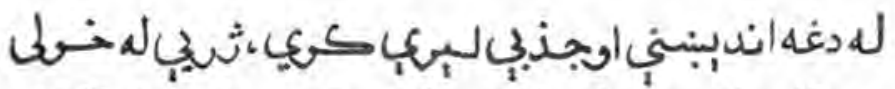

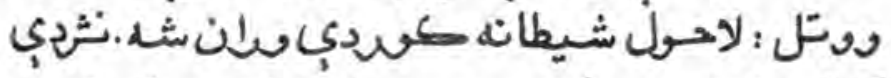

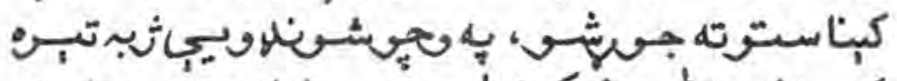

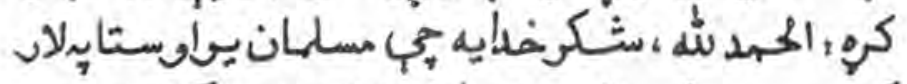

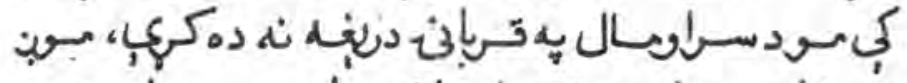

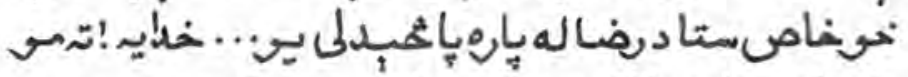

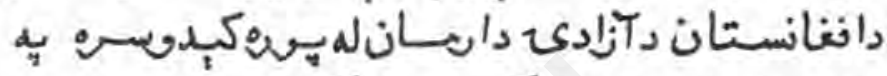

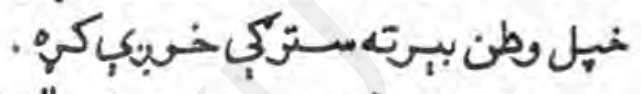

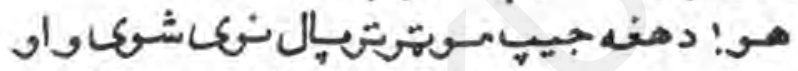

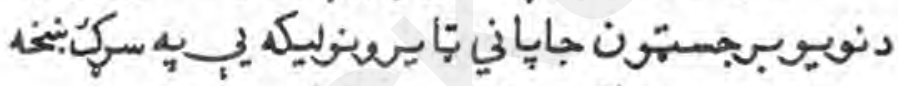

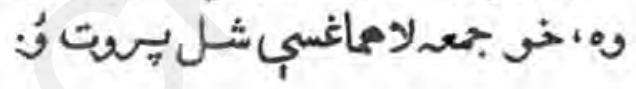

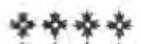

**⿻一㇉\% 


\section{دويرونومانبام}

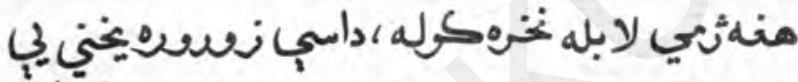

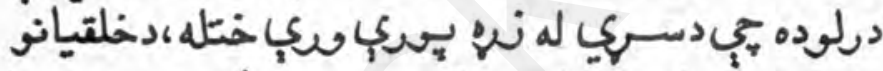

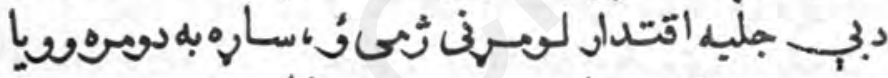

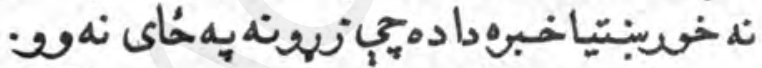

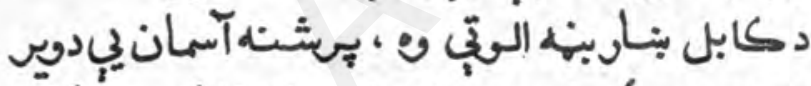

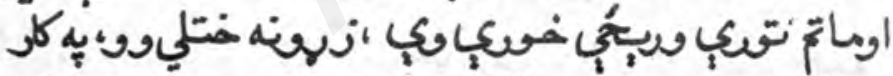

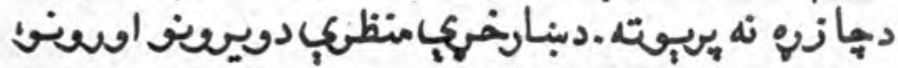

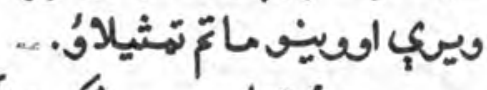

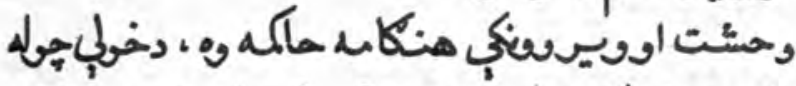

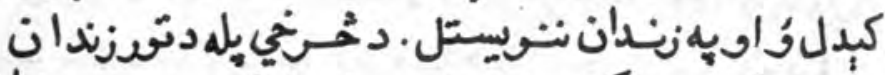

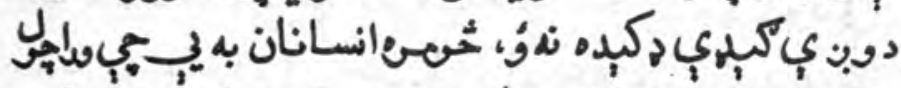

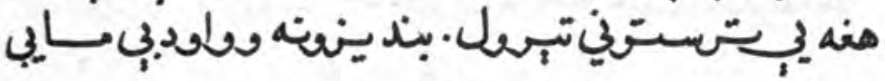
or 


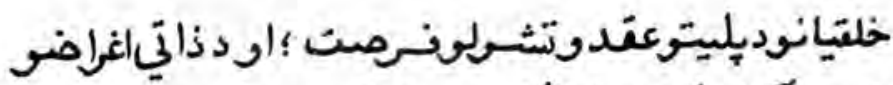

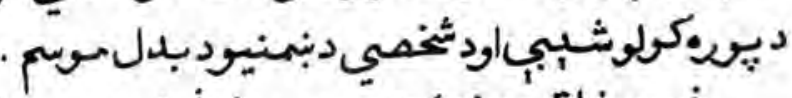

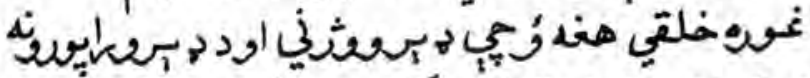

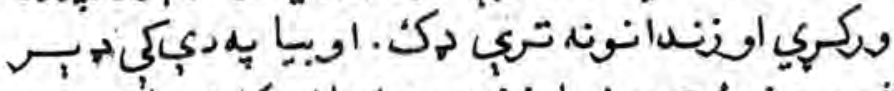

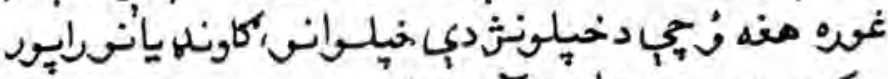

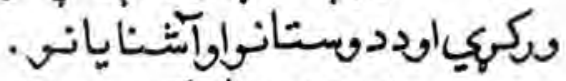

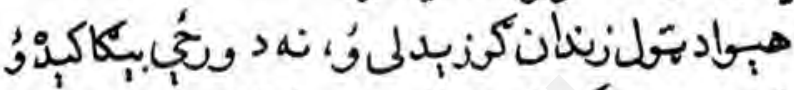

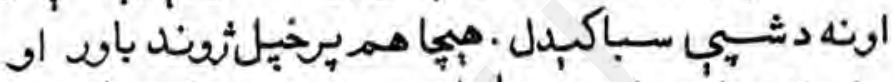

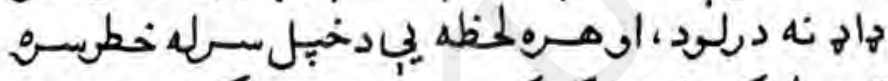

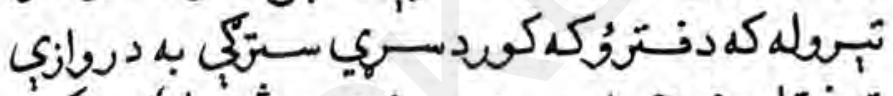

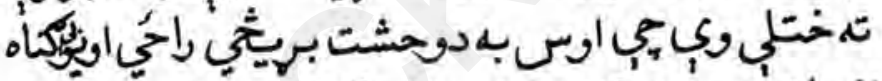

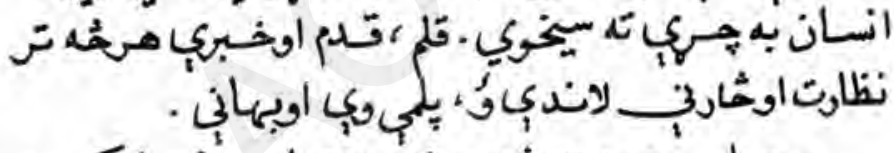

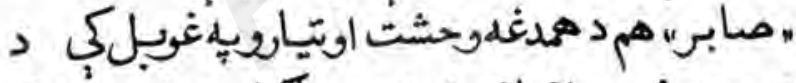

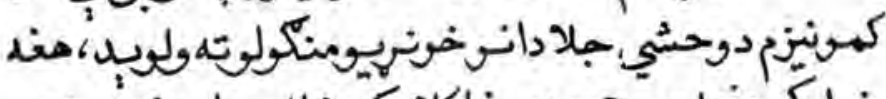

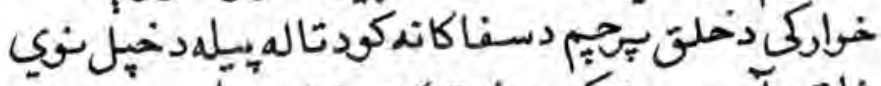

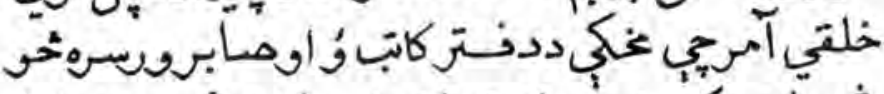

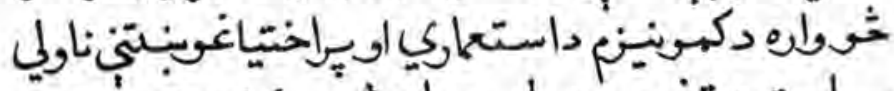

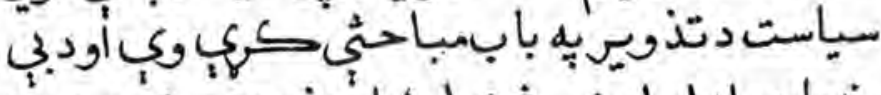

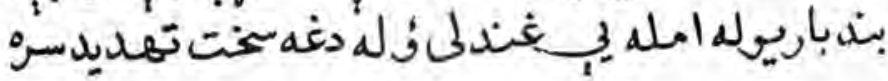




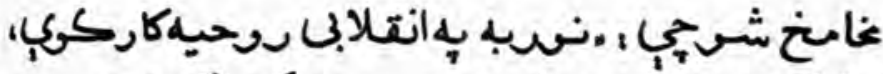

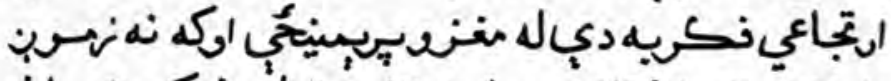

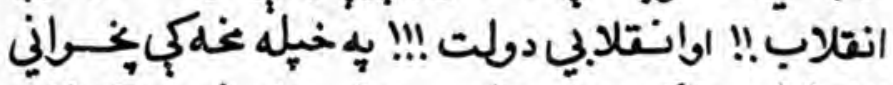

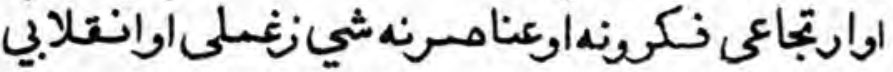

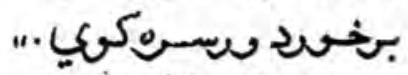

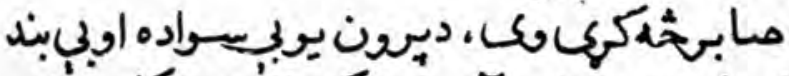

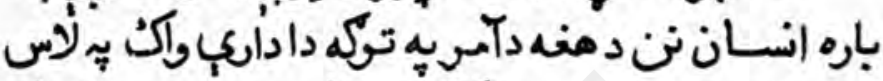

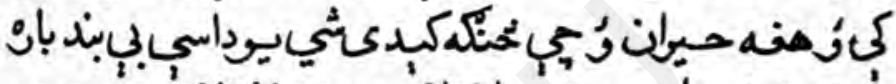

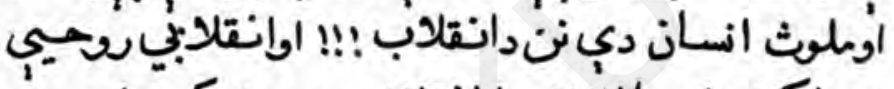

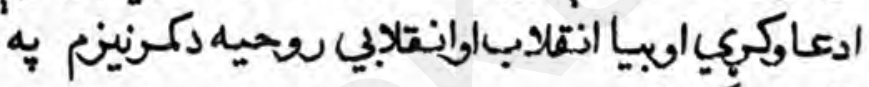

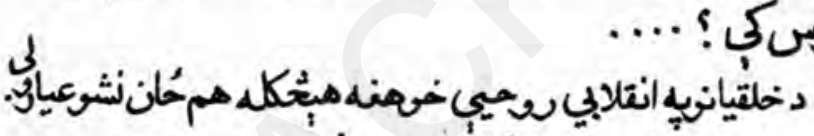

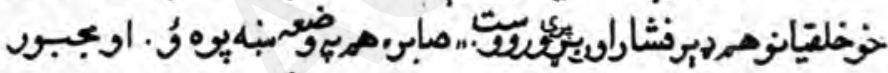

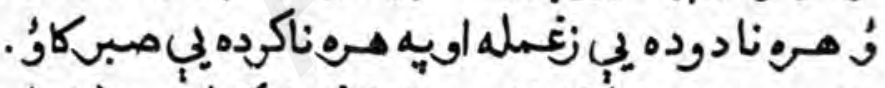

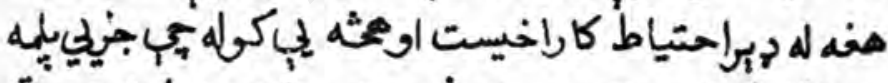

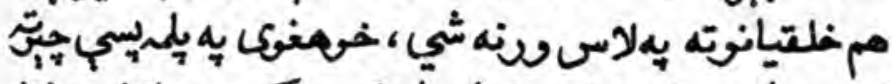

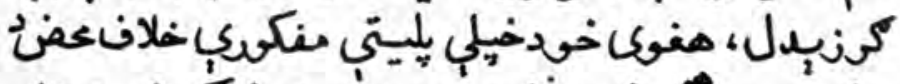

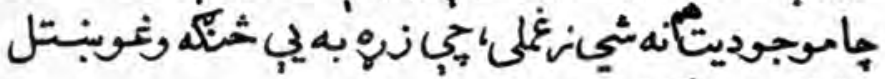

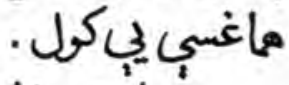

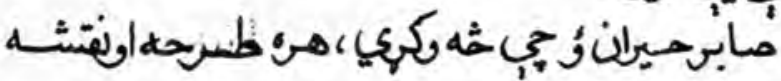




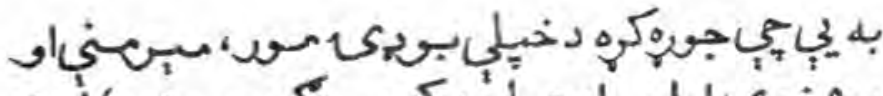

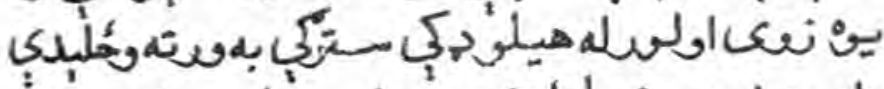

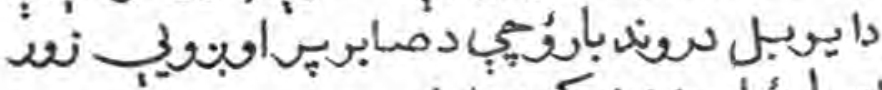

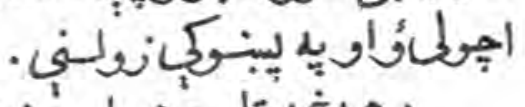

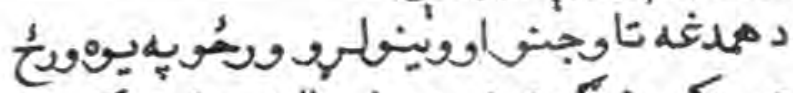

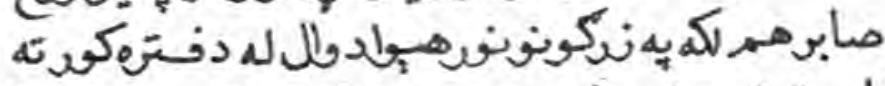

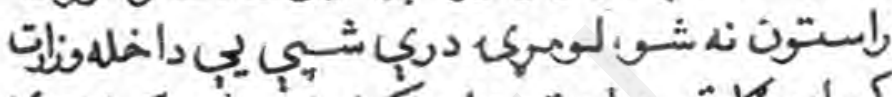

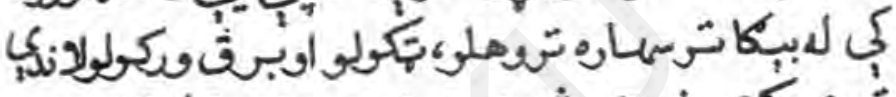

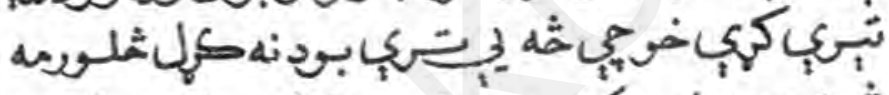

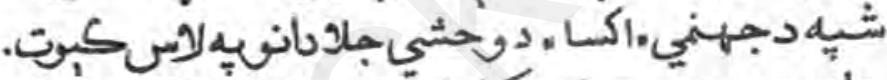

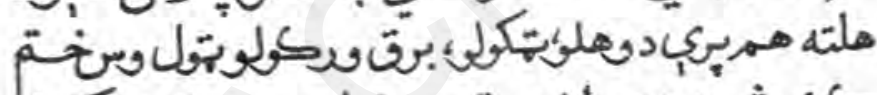

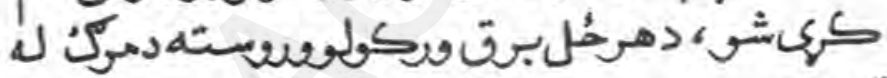

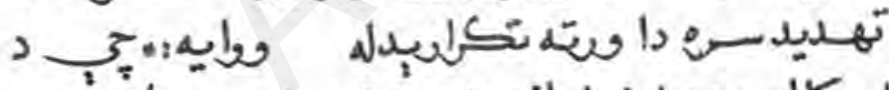

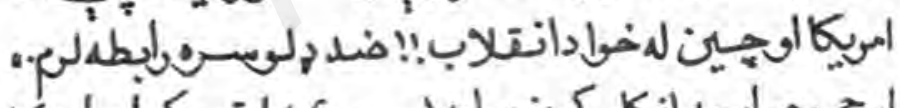

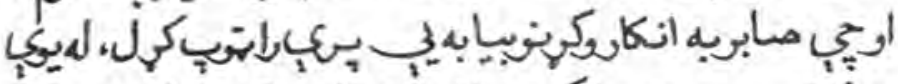

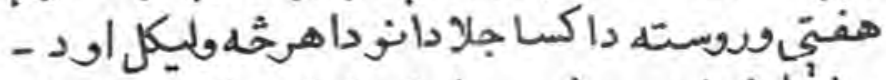

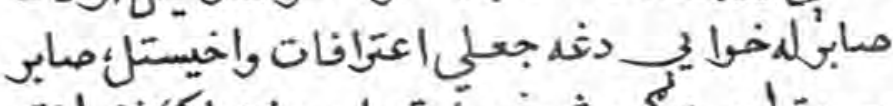

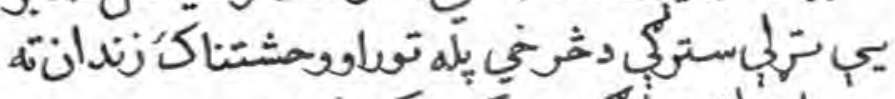

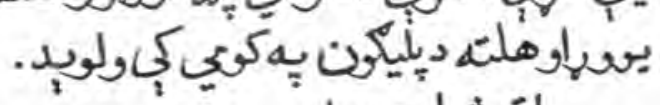

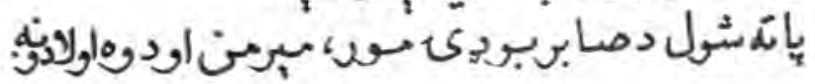




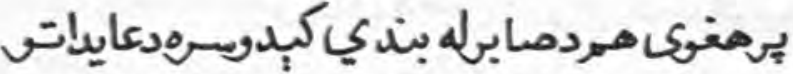

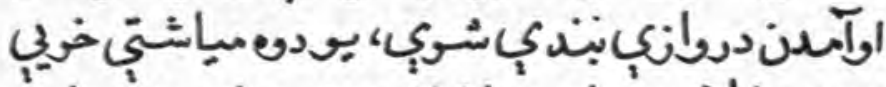

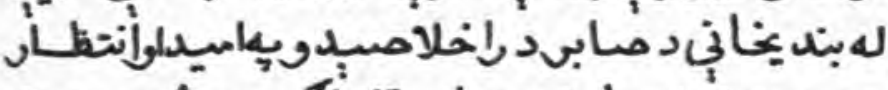

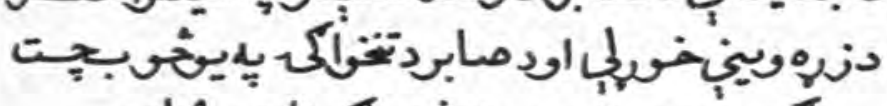

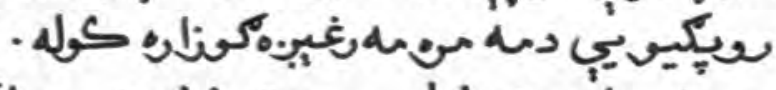

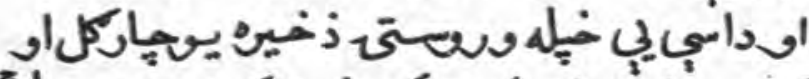

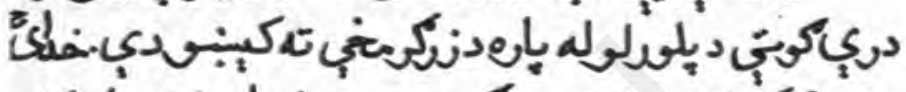

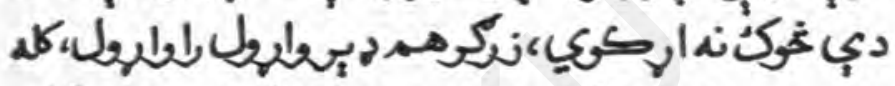

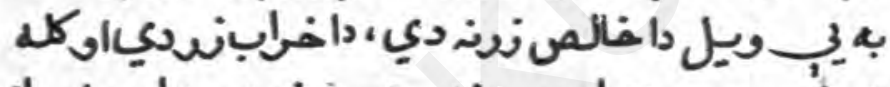

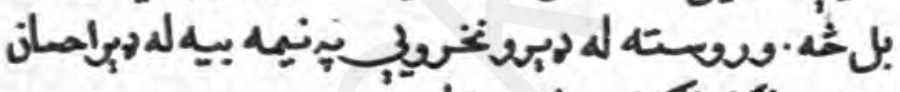

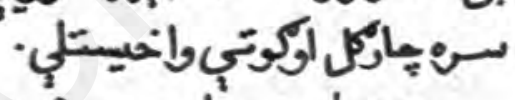

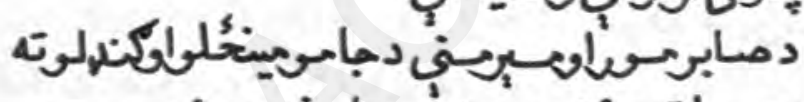

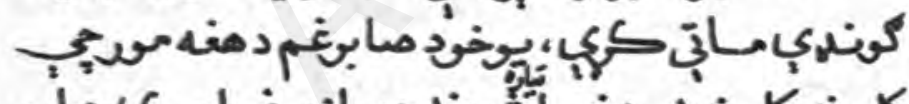

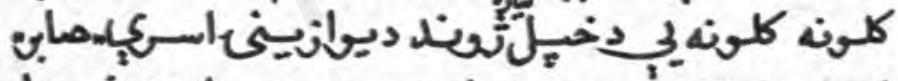

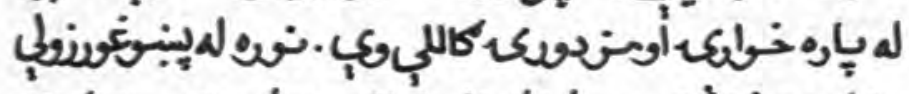

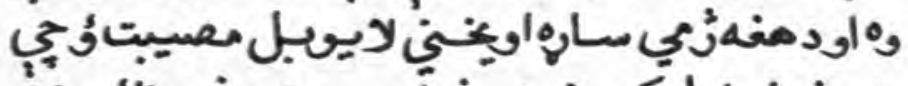

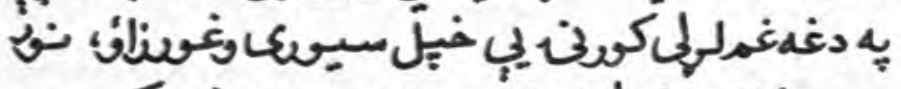

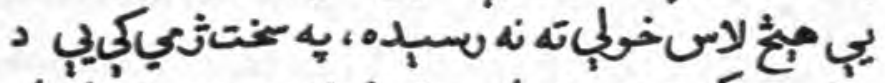

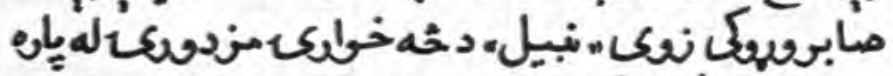

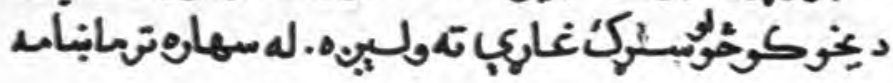




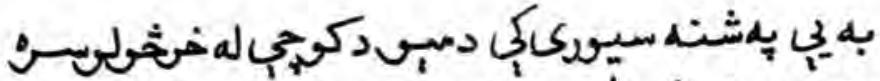

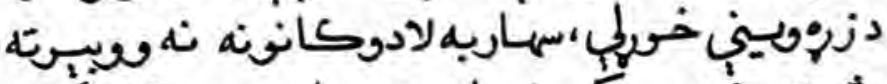

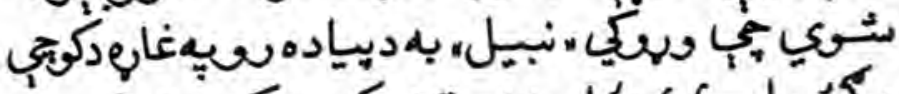

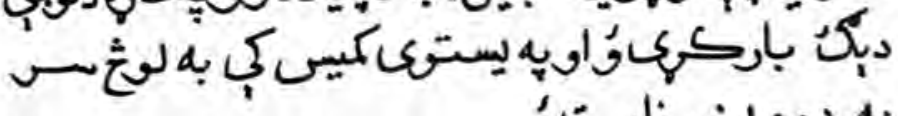

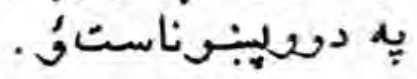

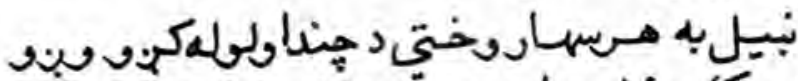

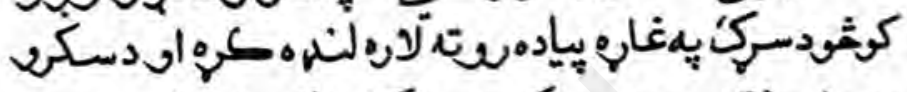

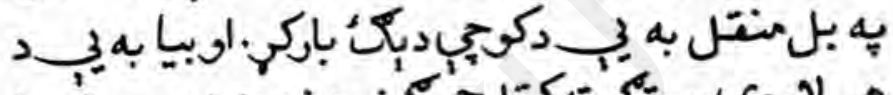

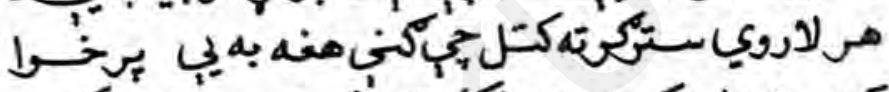

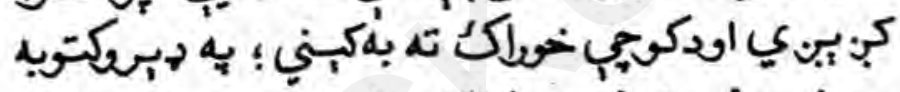

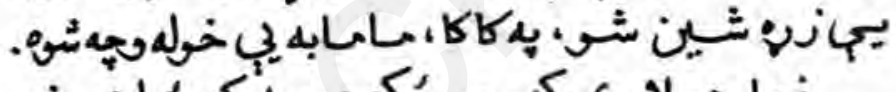

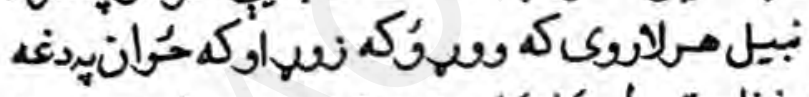

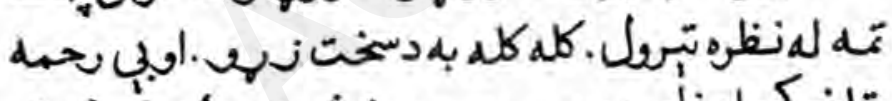

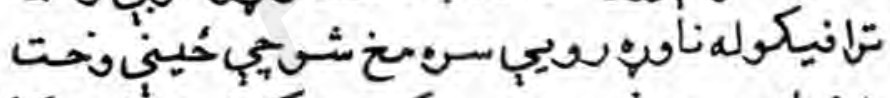

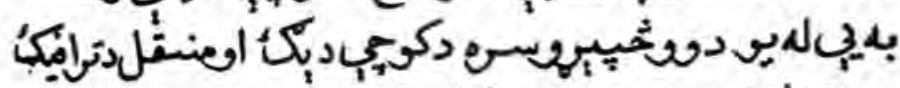

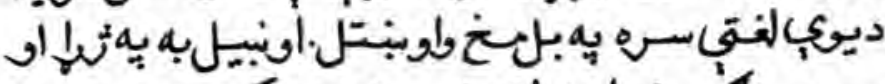

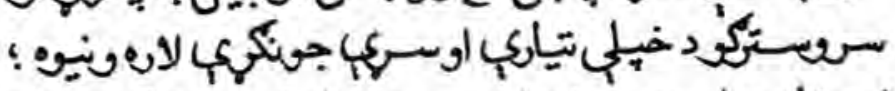

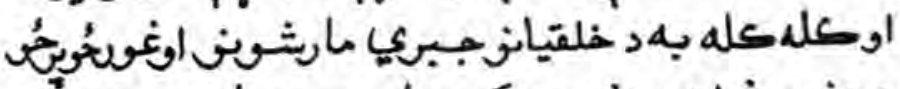

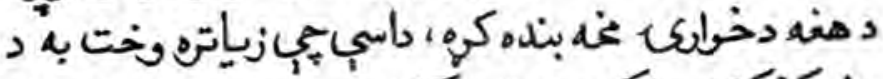

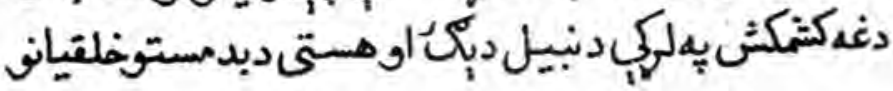




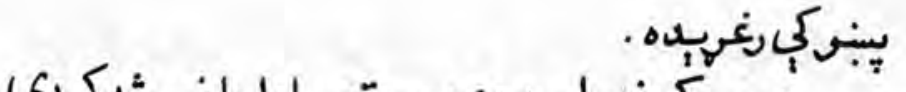

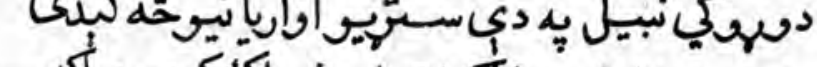

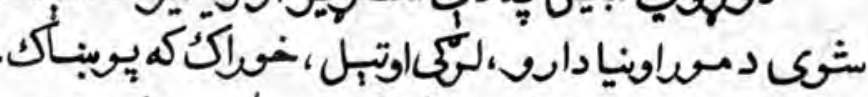

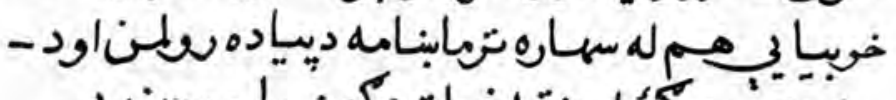

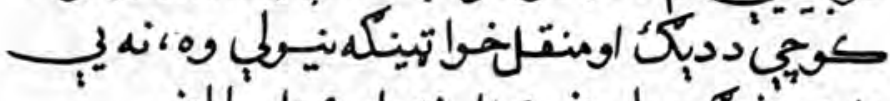

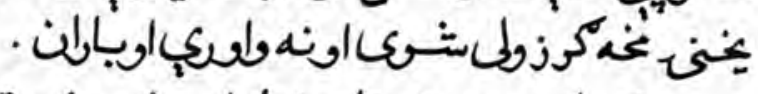

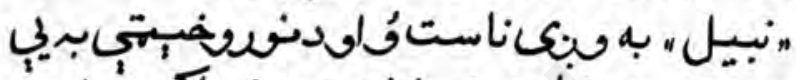

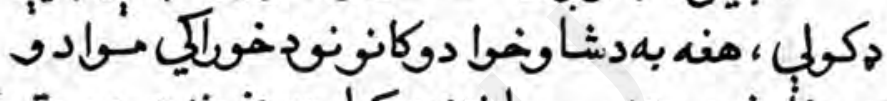

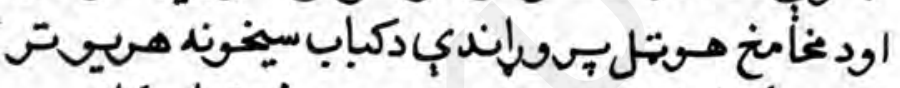

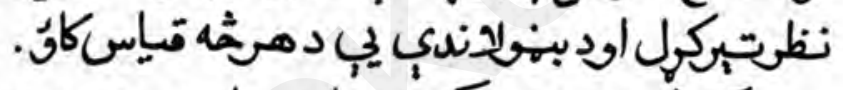

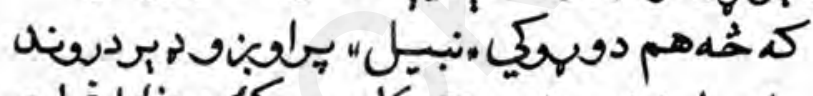

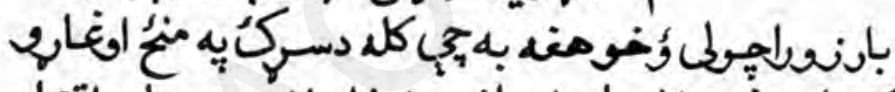

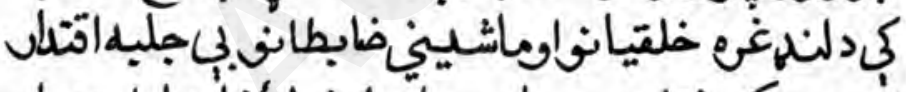

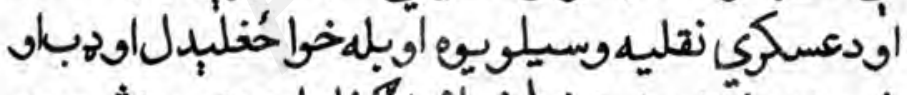

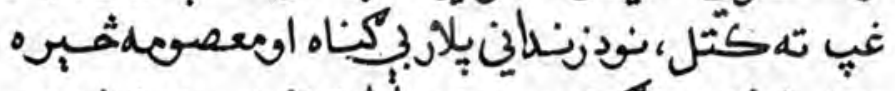

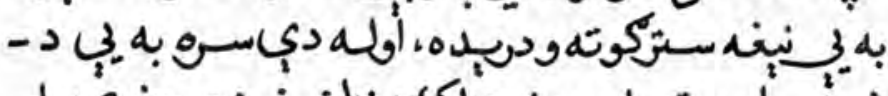

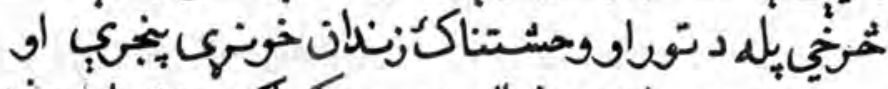

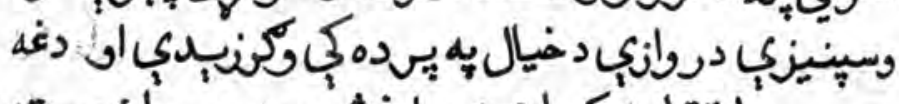

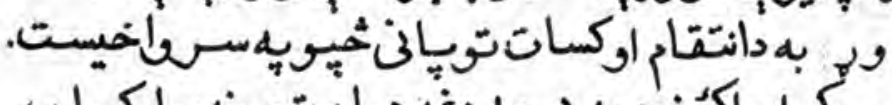

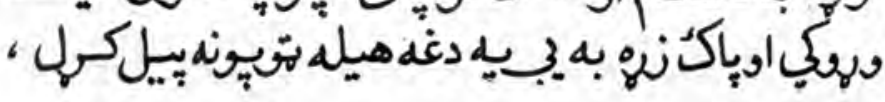
$\circ 9$ 


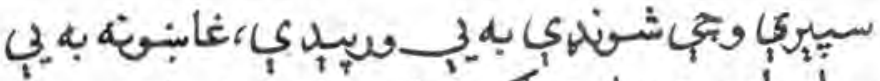

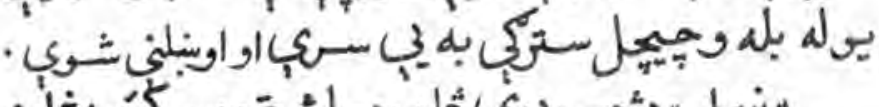

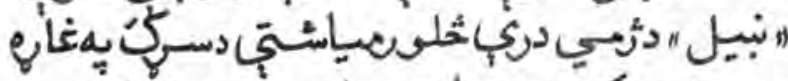

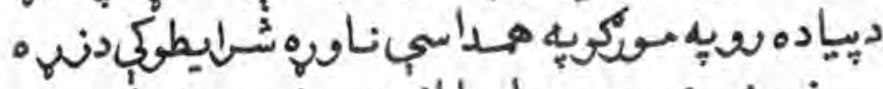

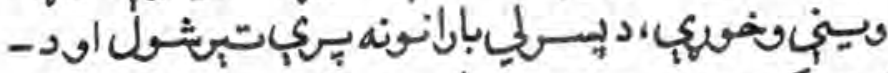

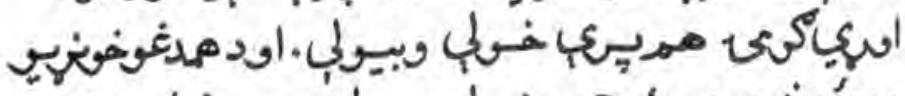

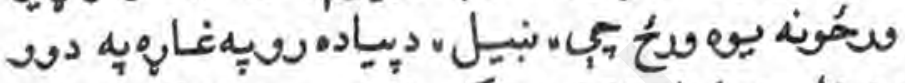

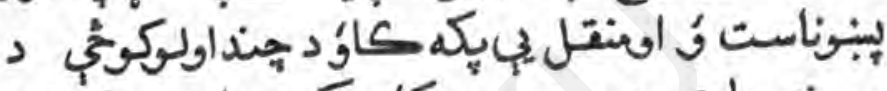

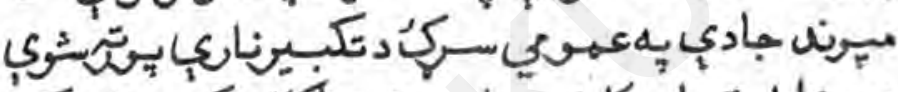

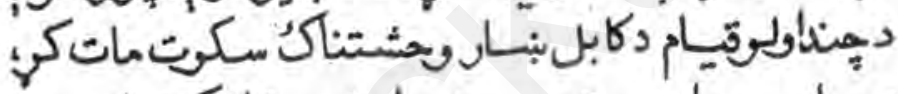

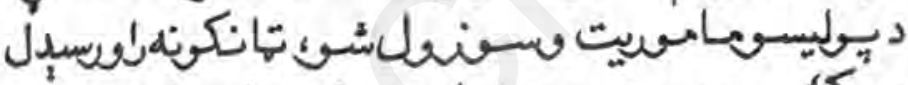

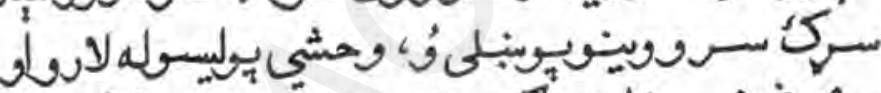

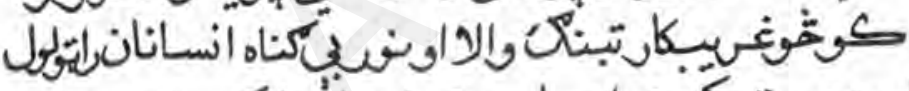

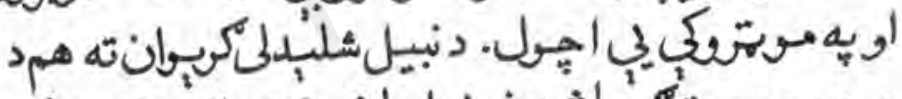

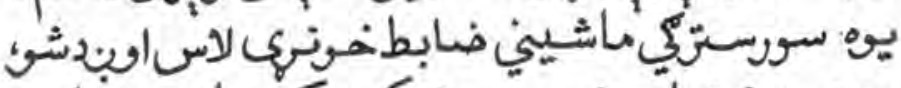

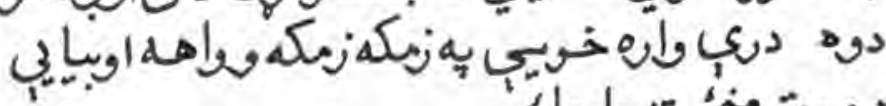

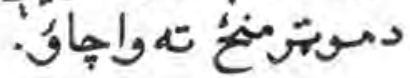

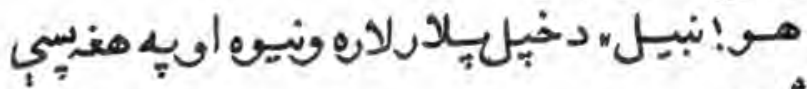
ورك شـى.

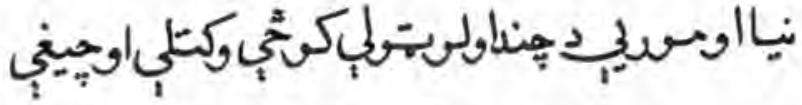




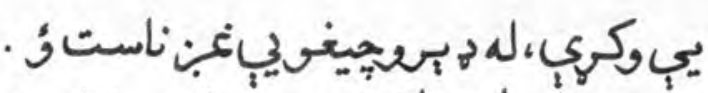

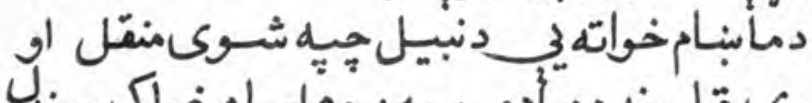

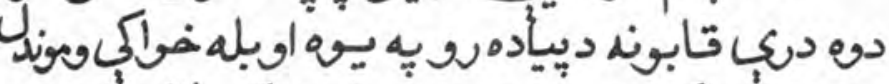

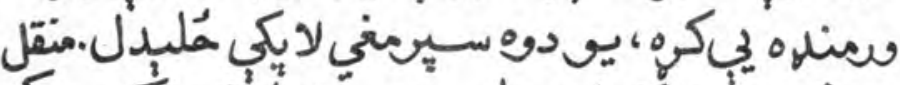

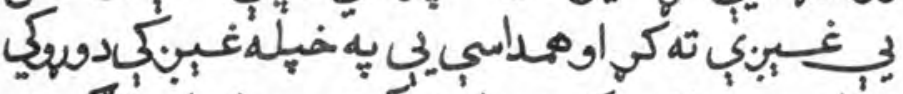

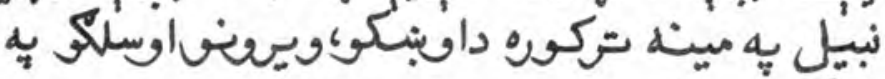

بدركم טسياؤ.

71 
IY 


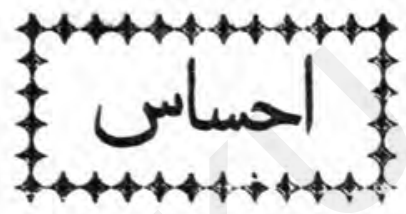

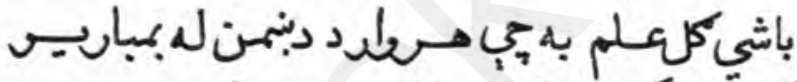

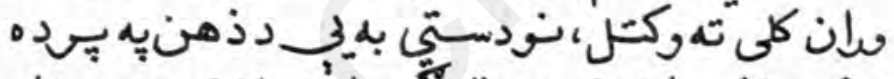

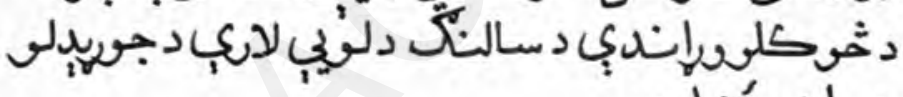

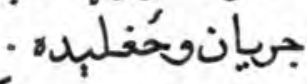

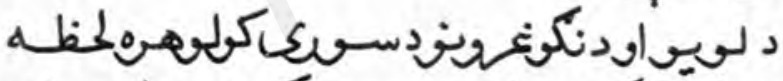

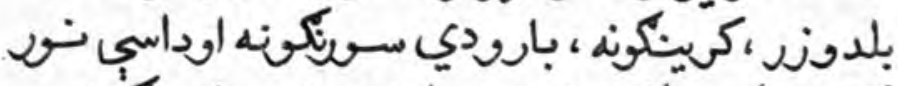

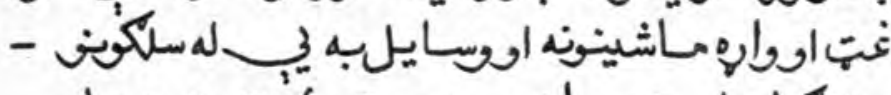

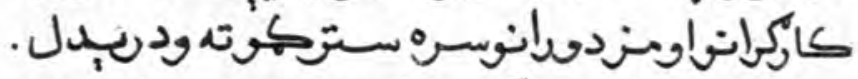

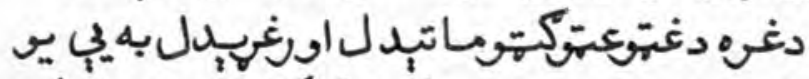

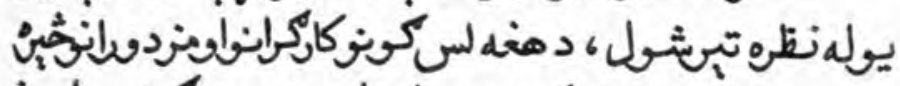

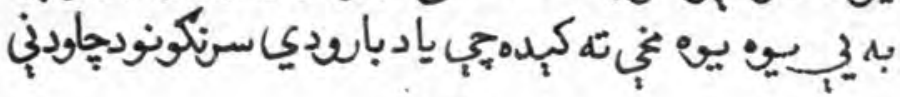




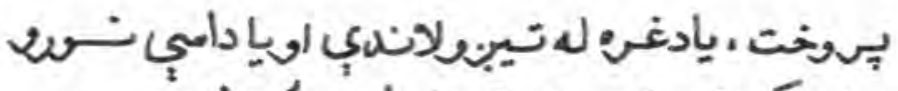

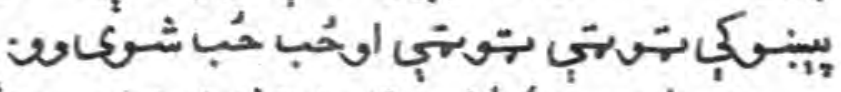

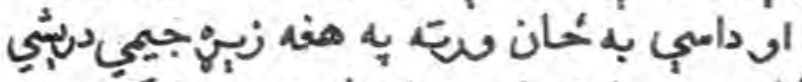

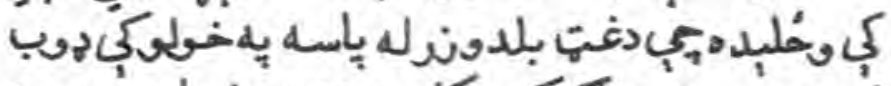

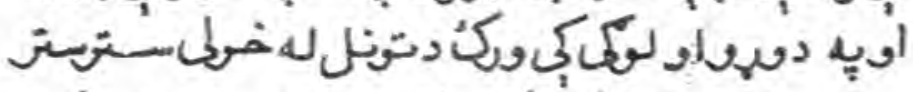

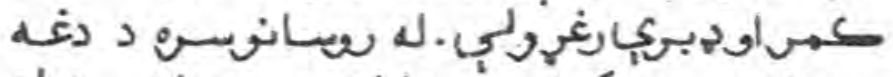

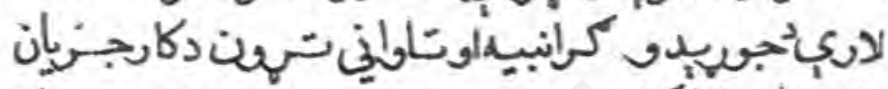

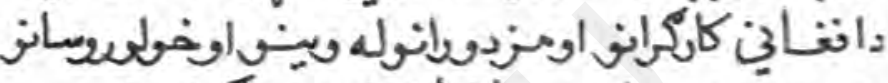

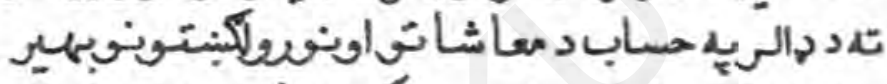

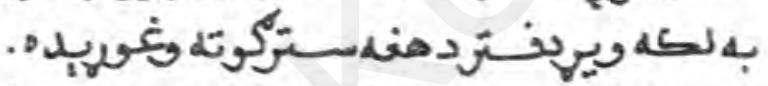

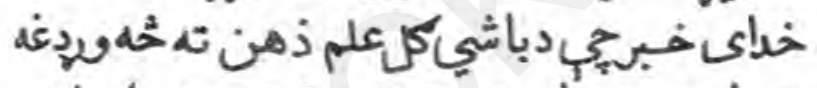

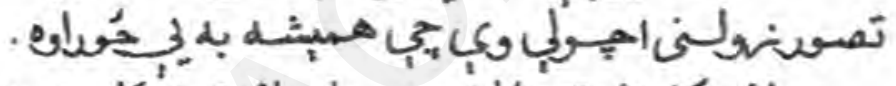

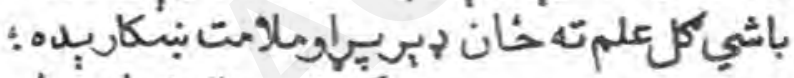

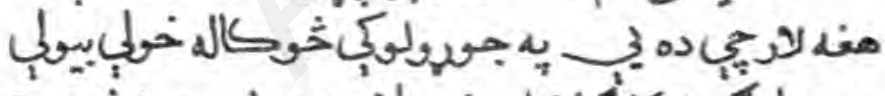

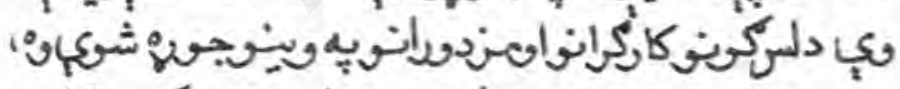

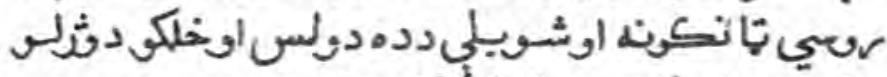

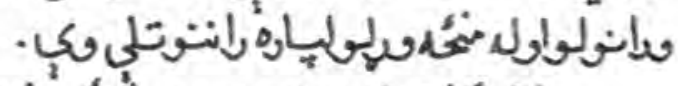

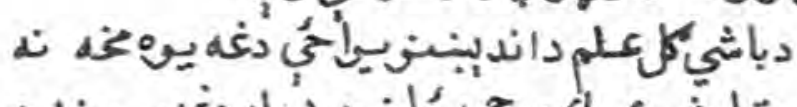

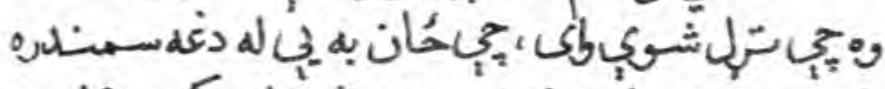

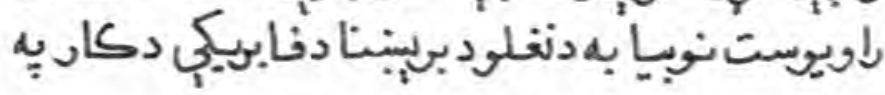




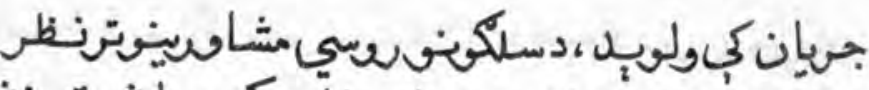

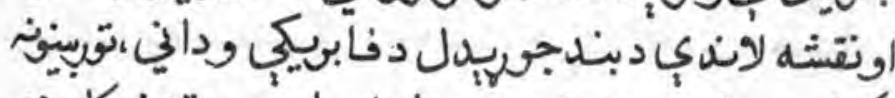

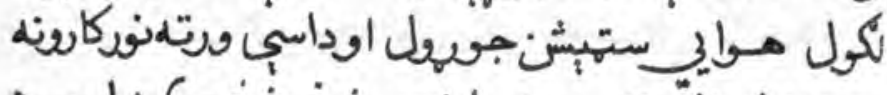

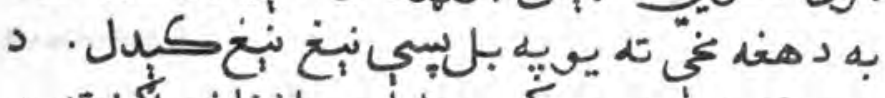

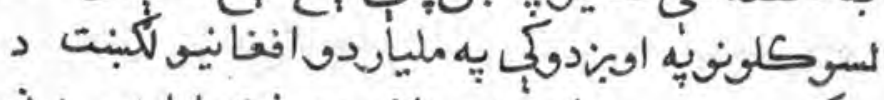

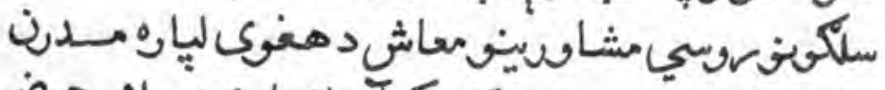

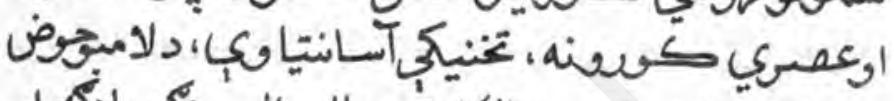

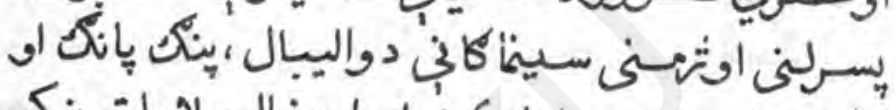

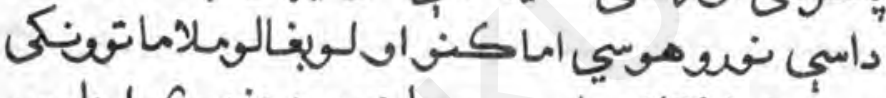

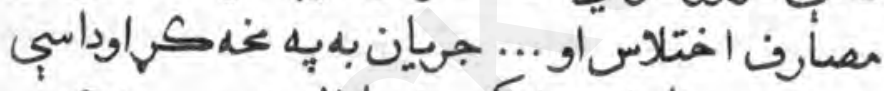

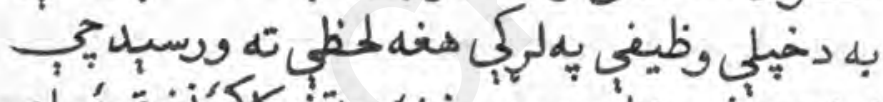

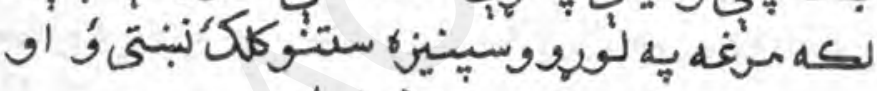

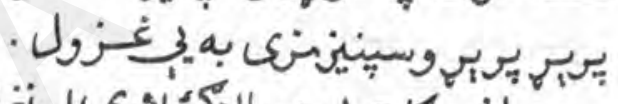

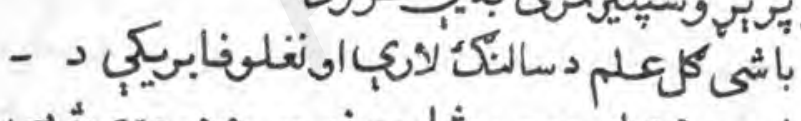

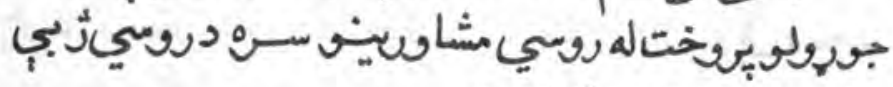

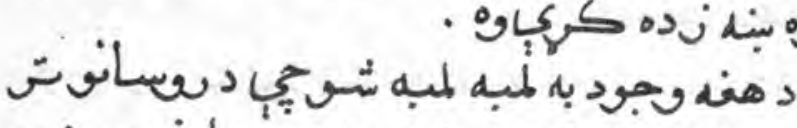

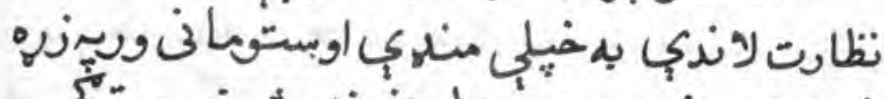

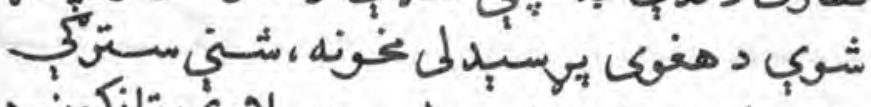

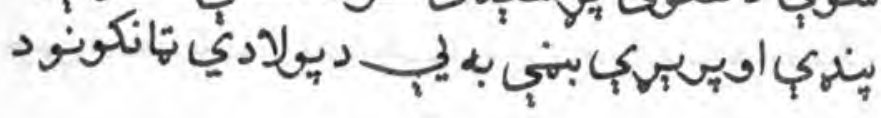




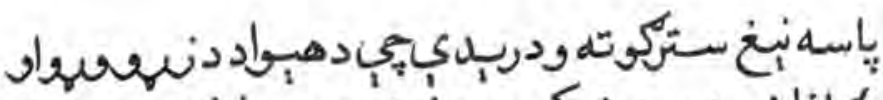

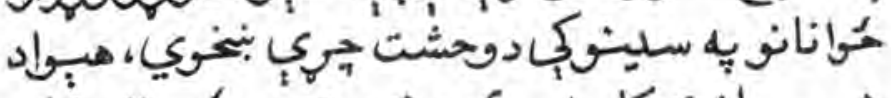

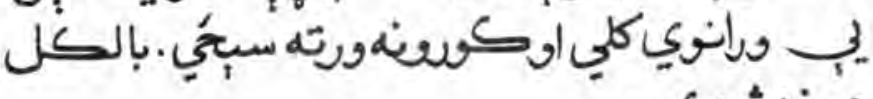

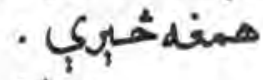

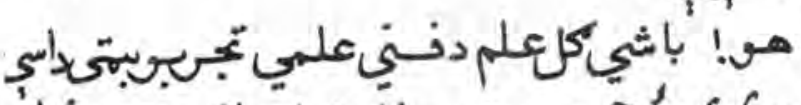

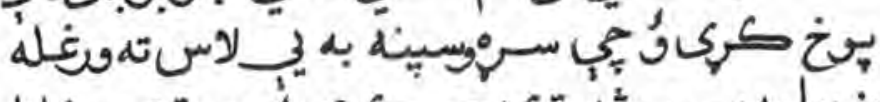

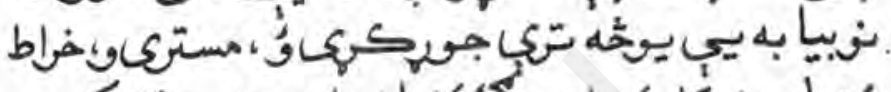

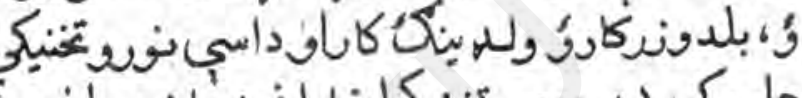

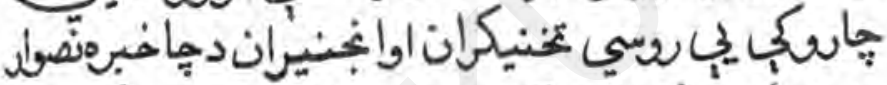

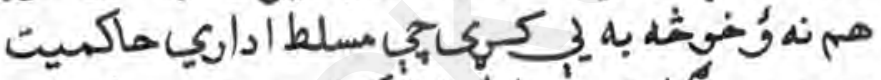

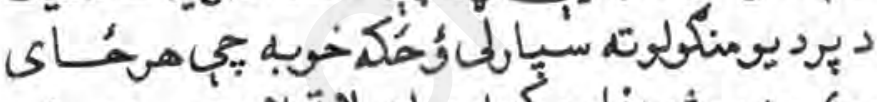

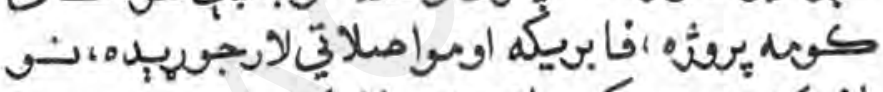

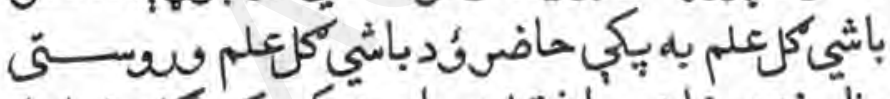

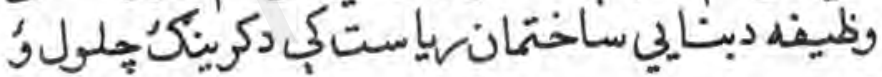

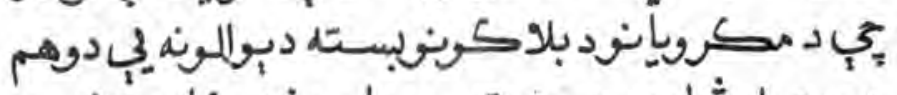

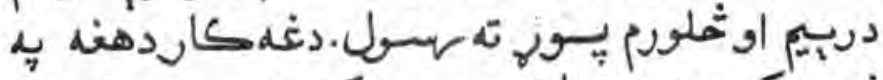

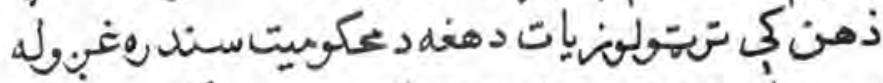

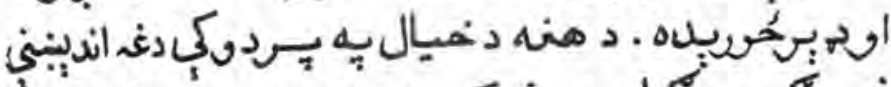

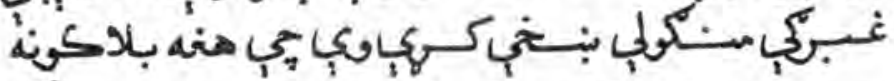

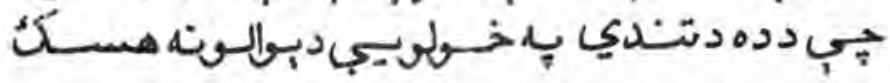




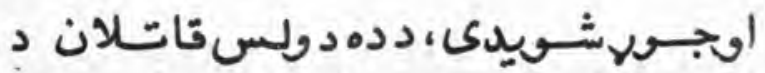

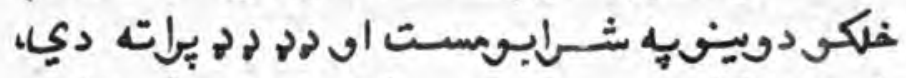

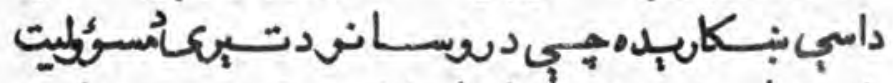

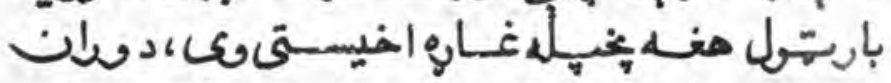

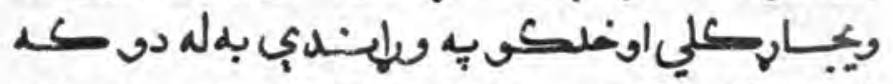

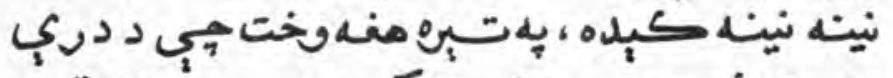

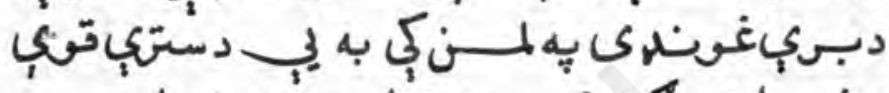

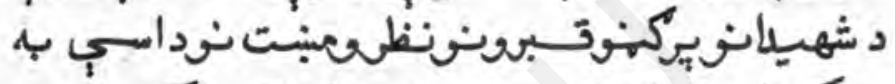

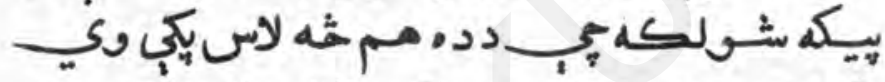

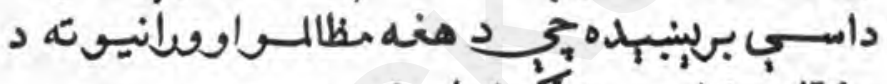

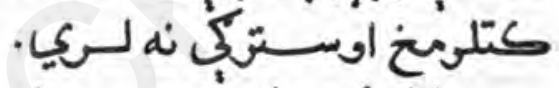

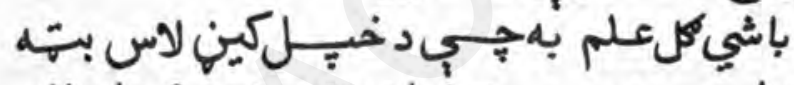

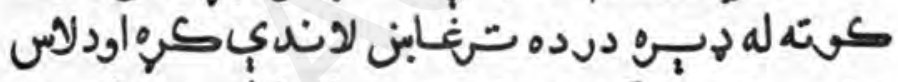

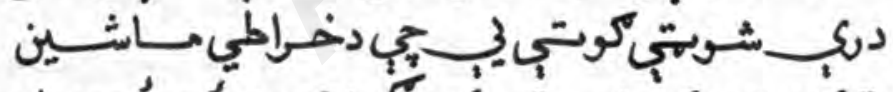

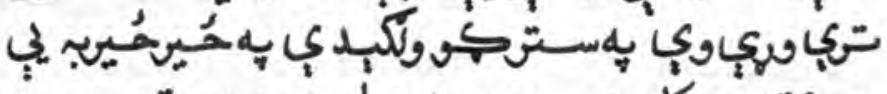

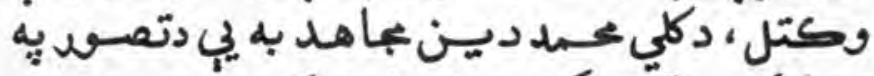

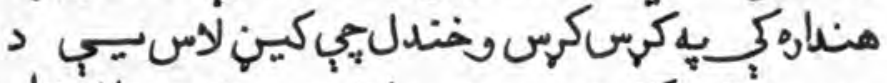

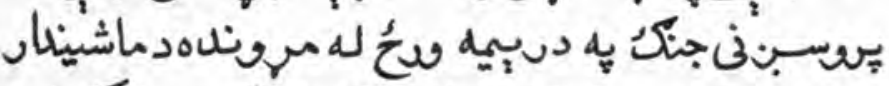

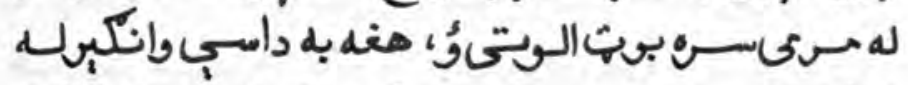

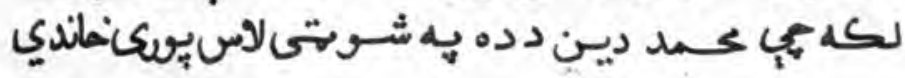




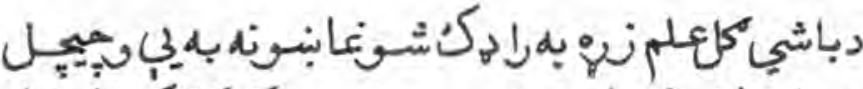

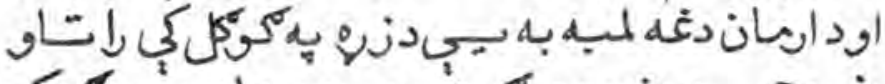

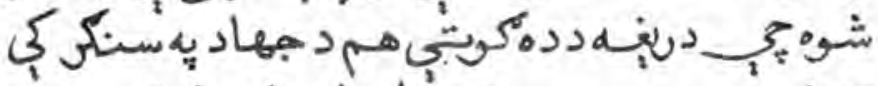

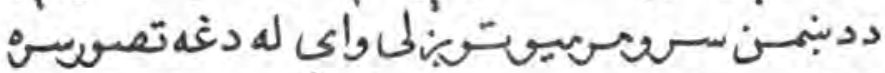

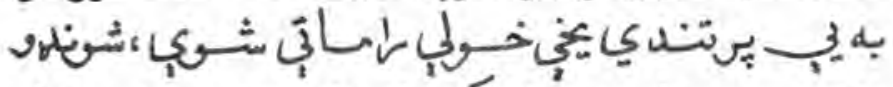

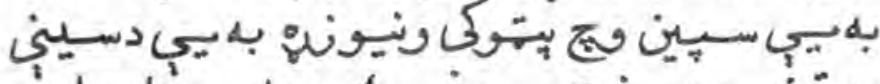

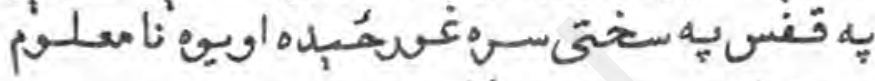

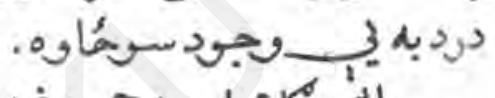

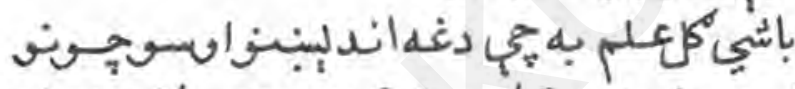

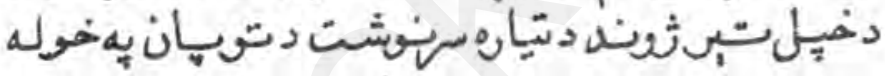

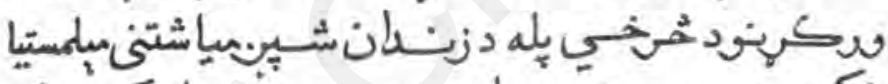

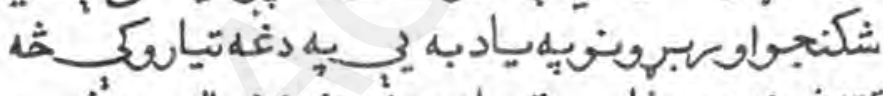

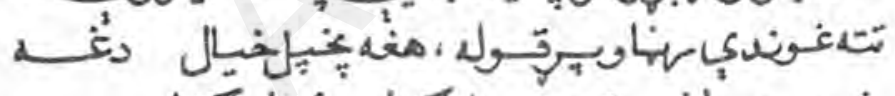

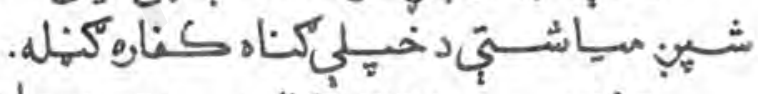

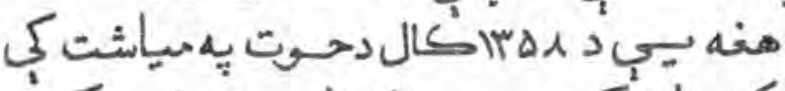

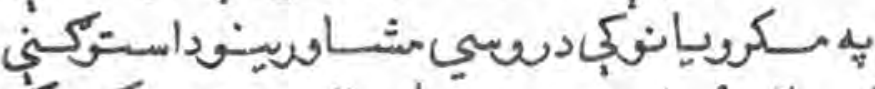

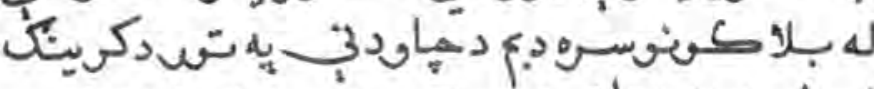

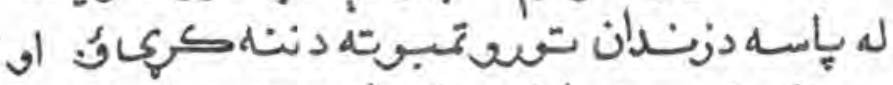

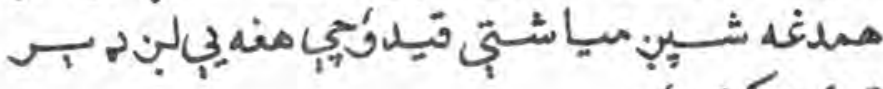
تصيمكئئي 


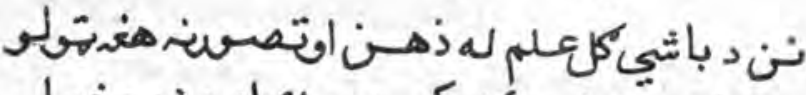

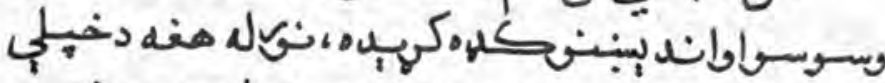

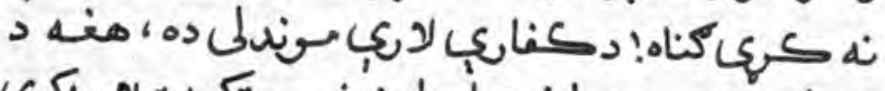

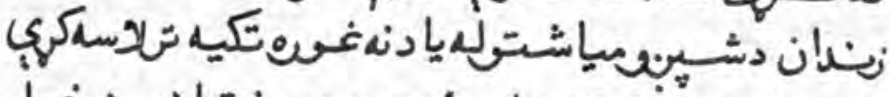

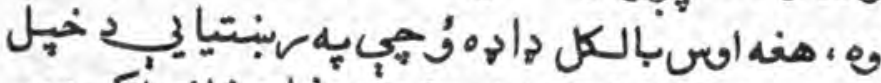

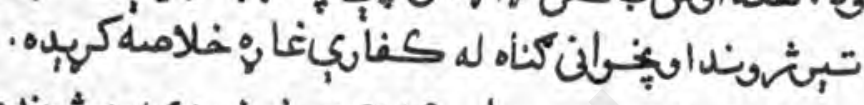

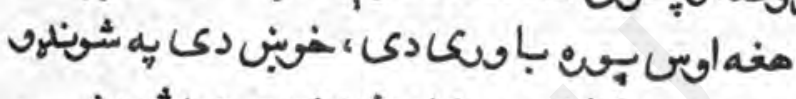
? -

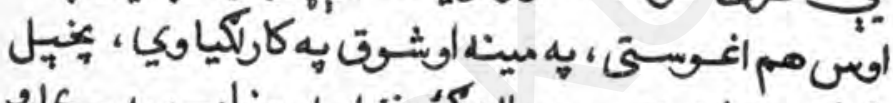

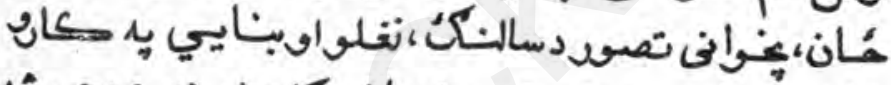

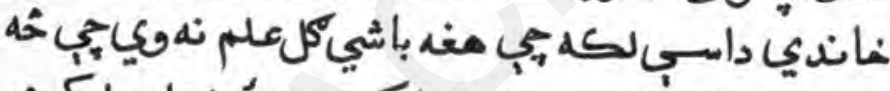

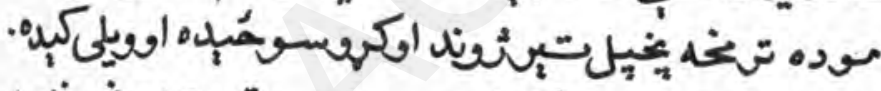

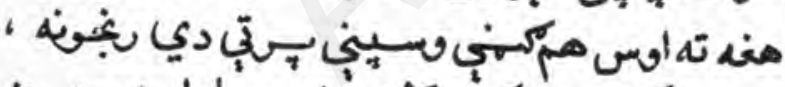
هـ

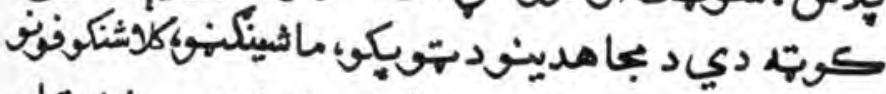

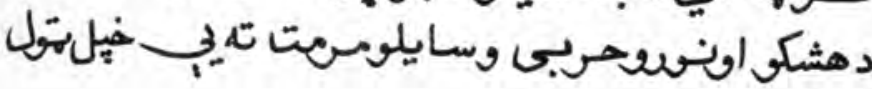
:

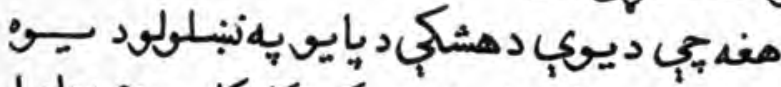

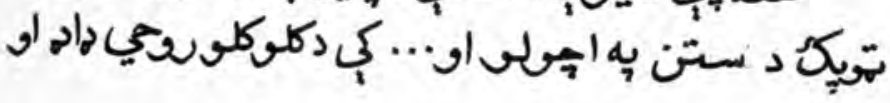




\section{قلبياطمينانسوندلمدى.}

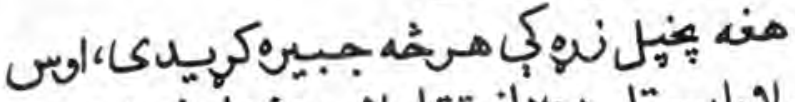

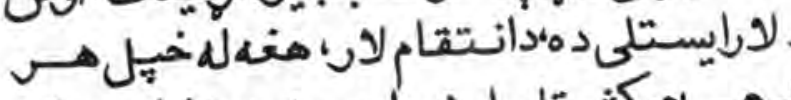

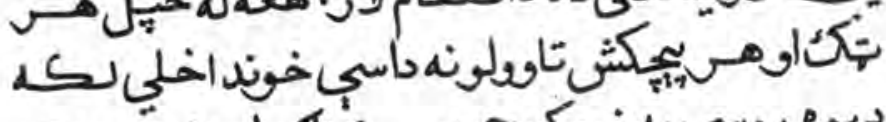

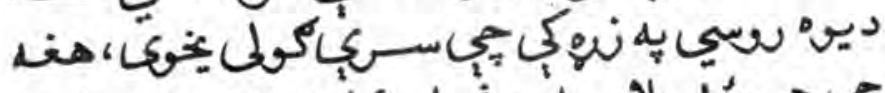

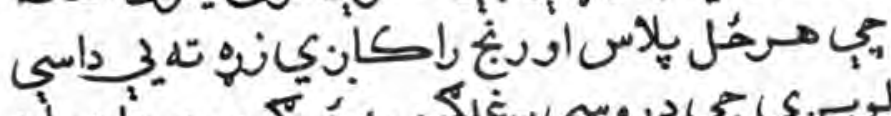

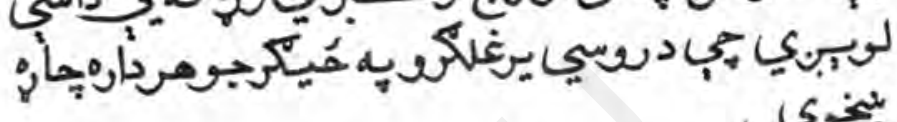

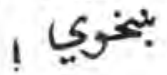




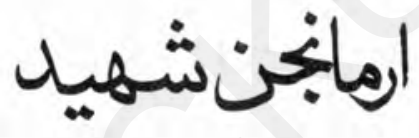

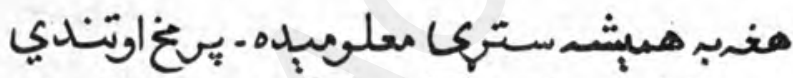

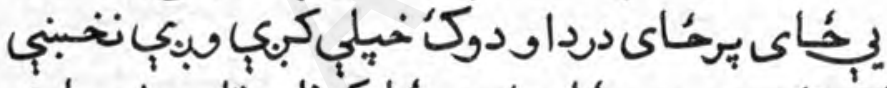

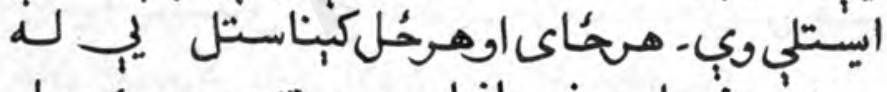

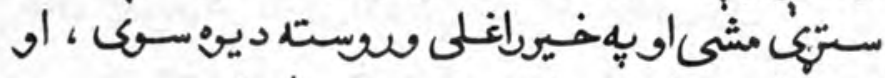

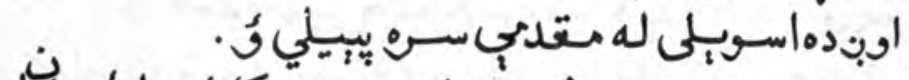

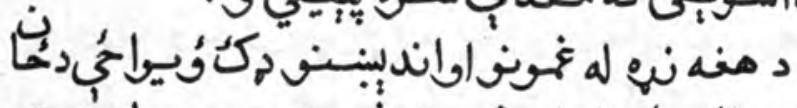

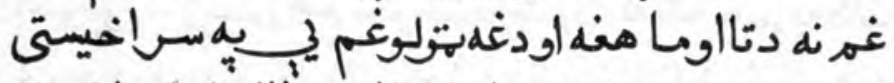

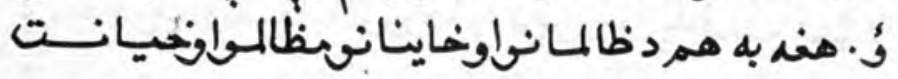

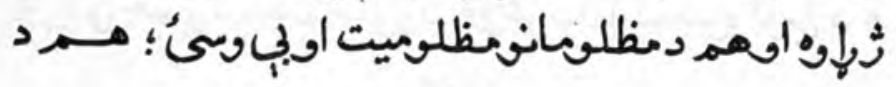




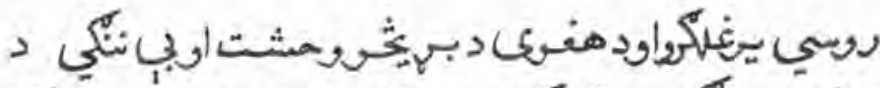

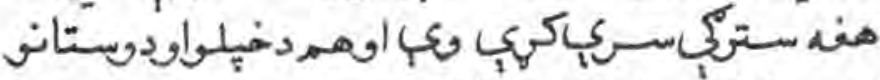

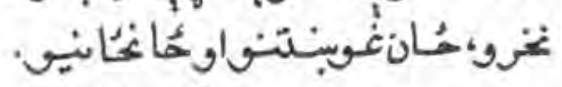

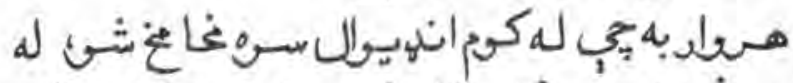

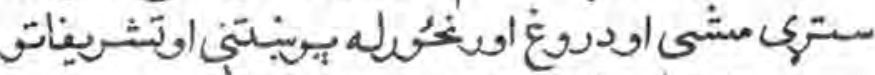

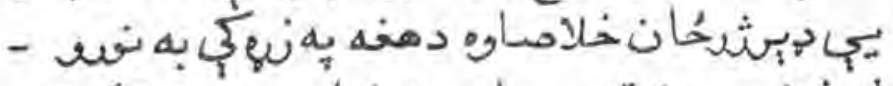

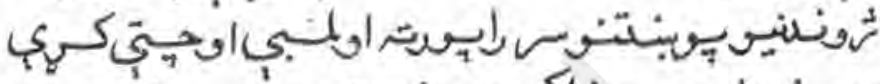

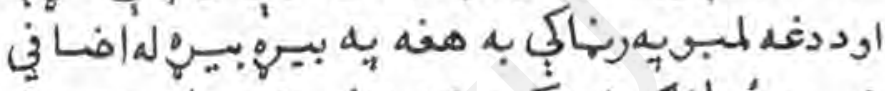

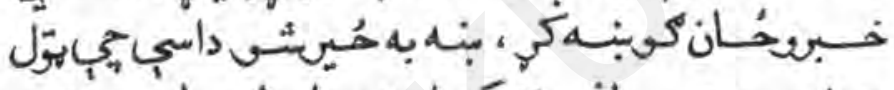

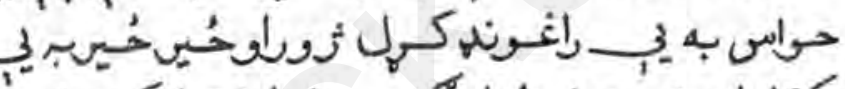

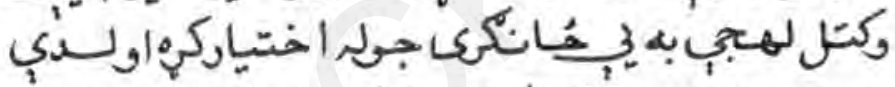

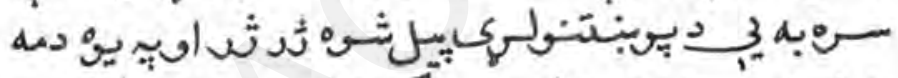

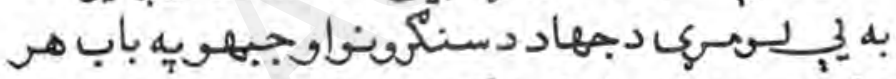

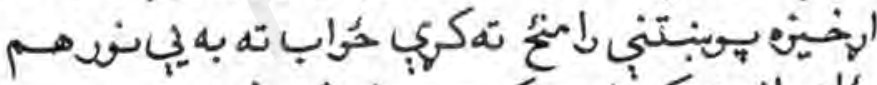

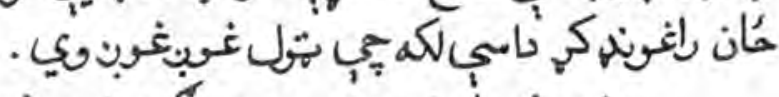

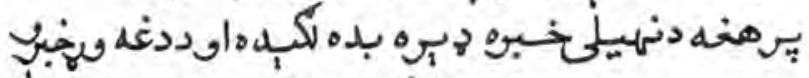

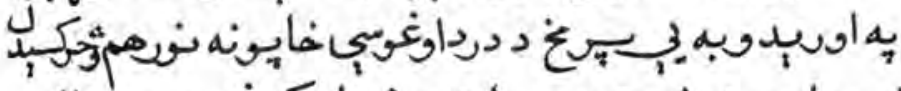

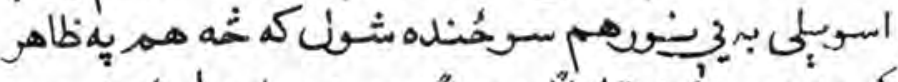

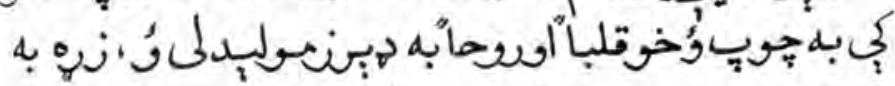

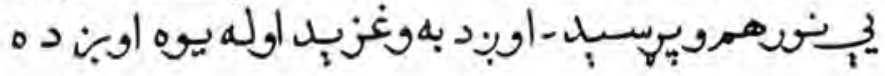




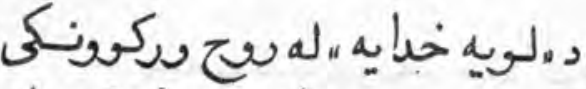

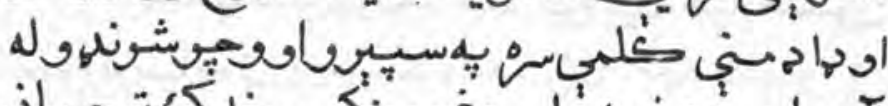

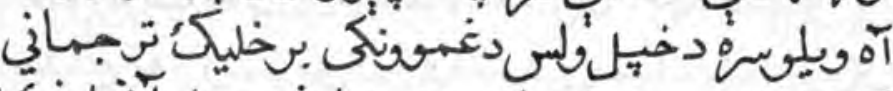

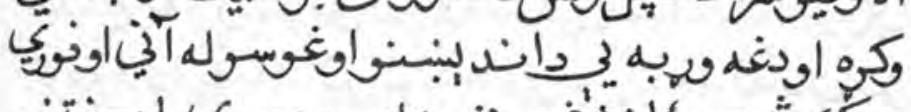

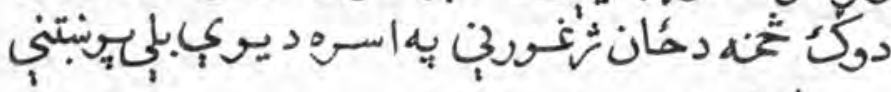

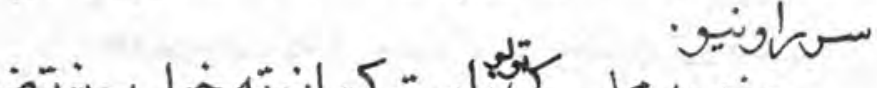

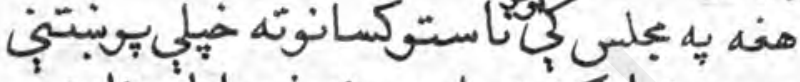

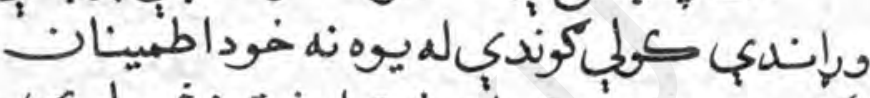

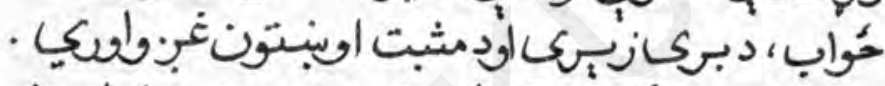

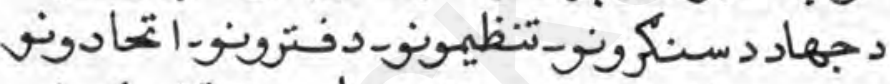

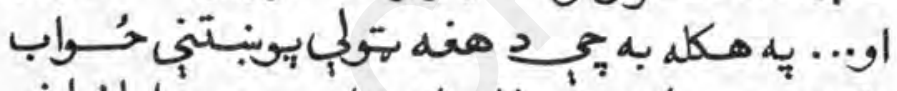

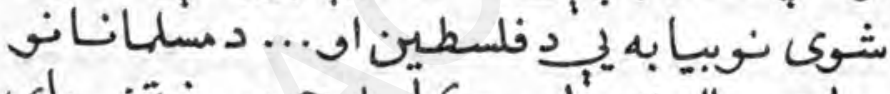

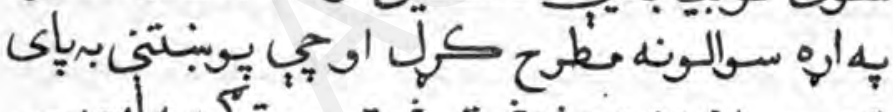

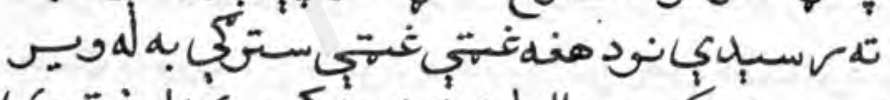

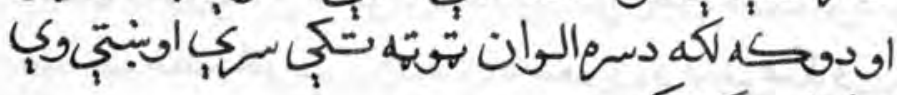

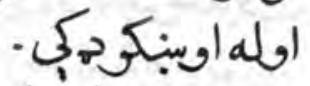

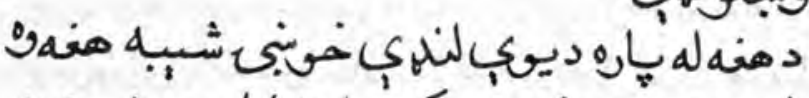

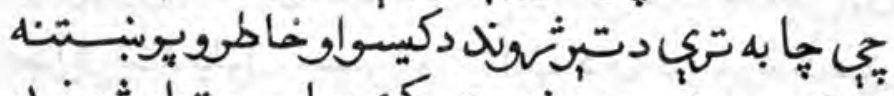

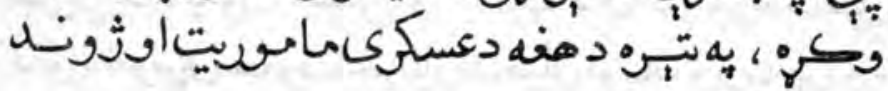

$$
\text { بوينبتندا }
$$




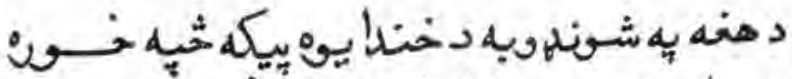

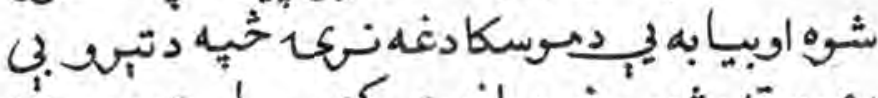

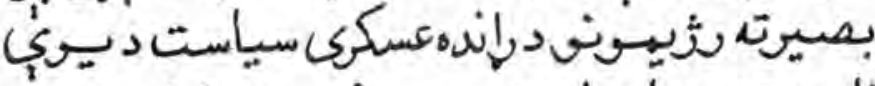

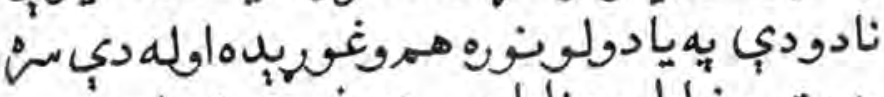

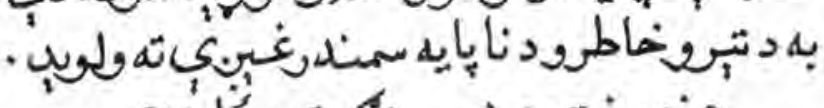

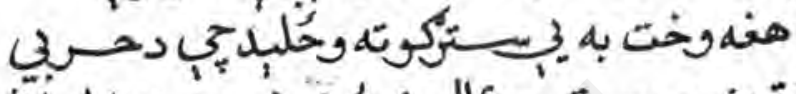

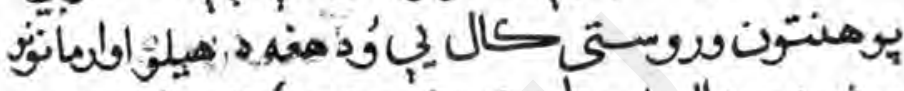

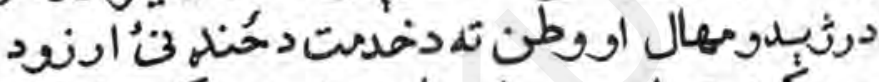

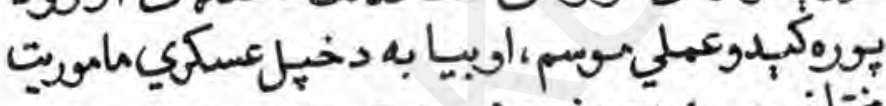

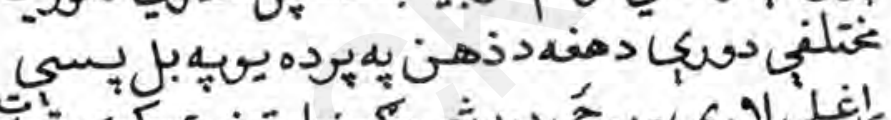

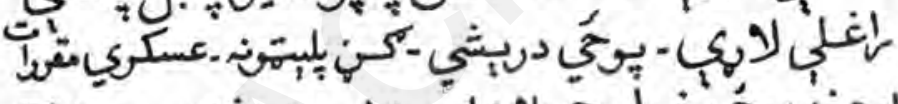

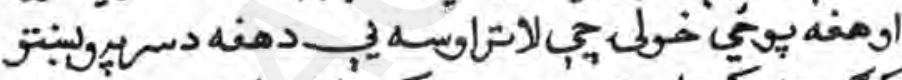

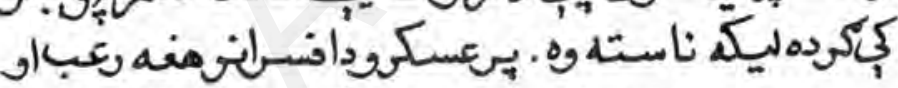

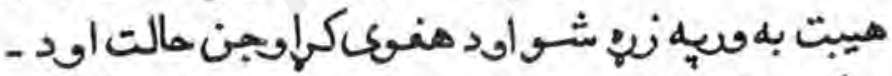

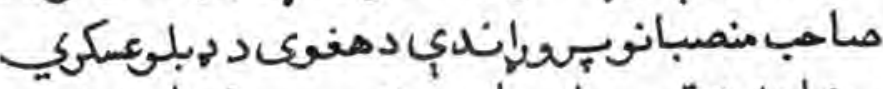

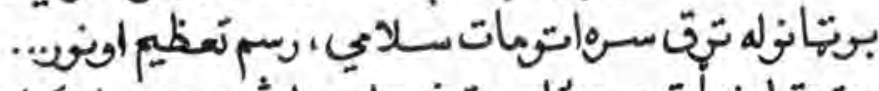

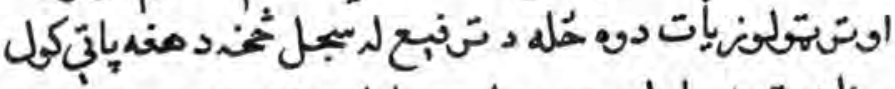

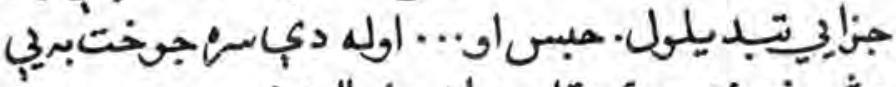

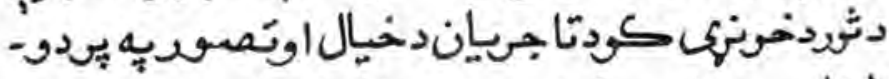

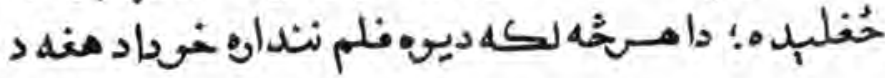




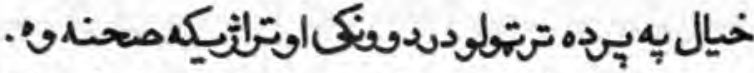

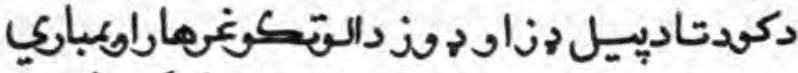

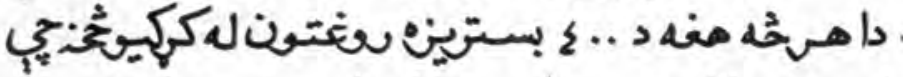

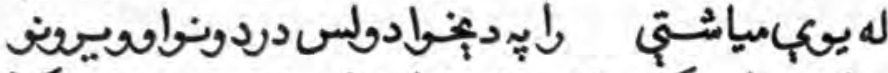

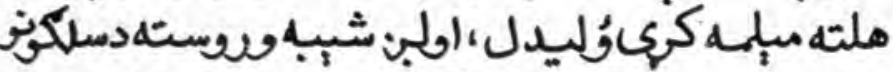

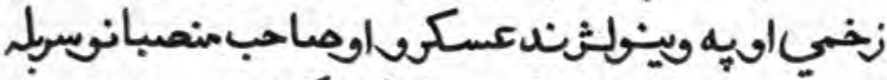

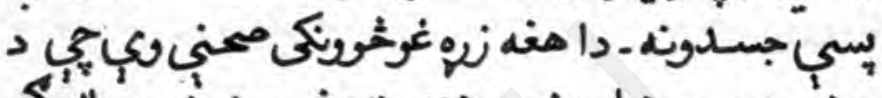

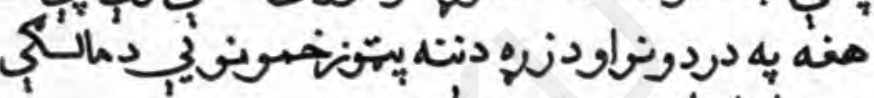
ديرلوارناسوحيثيث درليد.

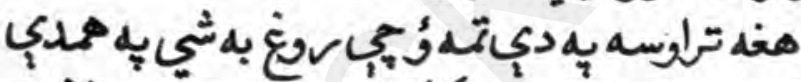

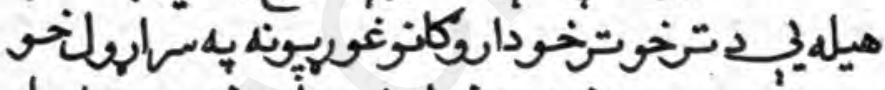

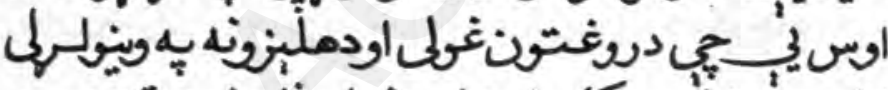

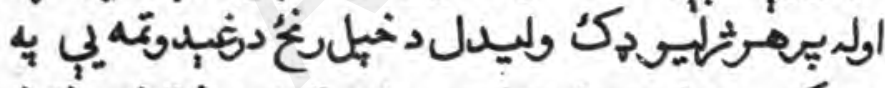

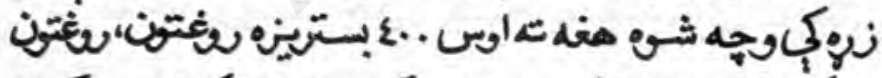

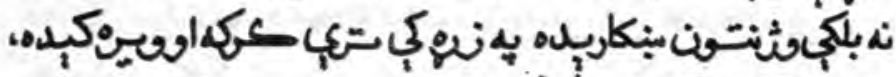

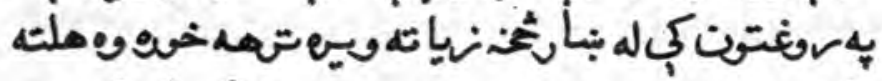

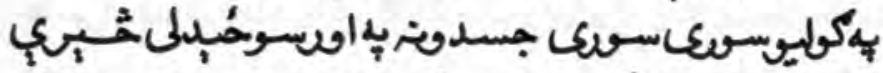

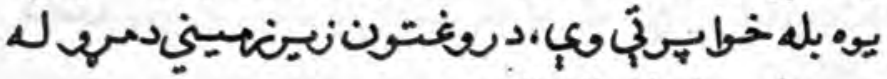
جسدؤمكه اوتالامالونه.

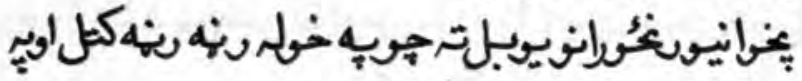




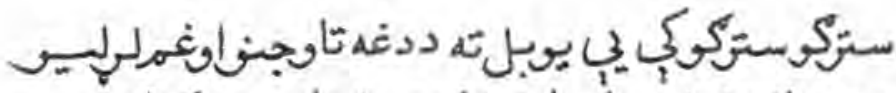

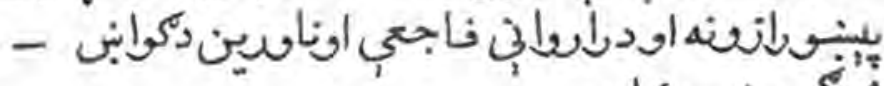
ثركندوبي كوله.

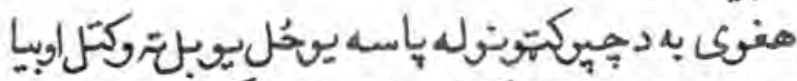

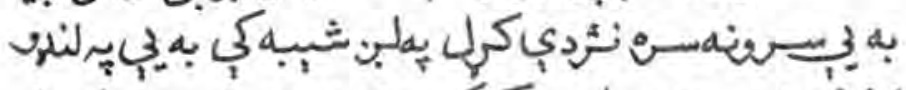

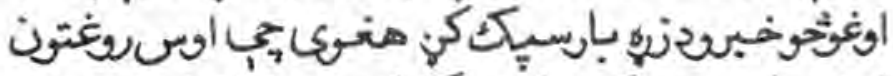

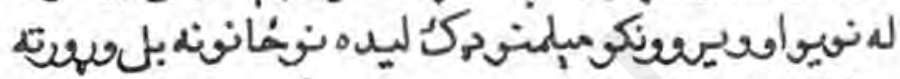

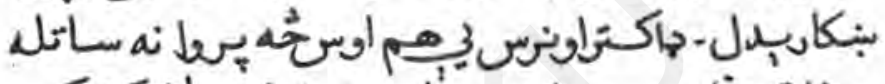

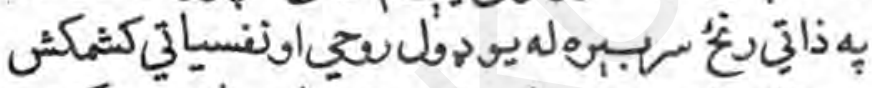

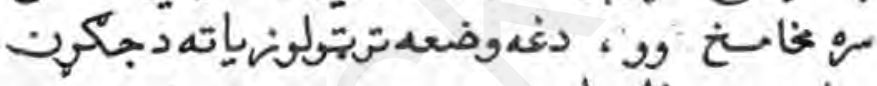

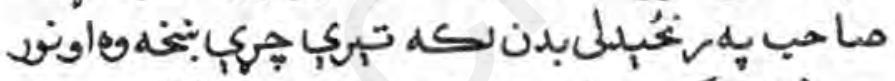

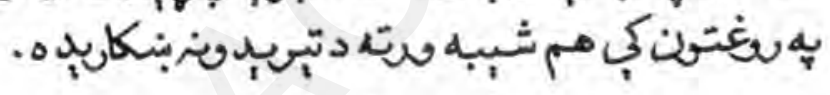
* 4

لسياصسيتاجكينصاحب تهسكري دريشي

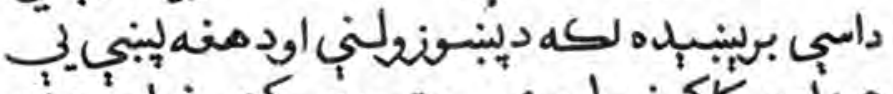

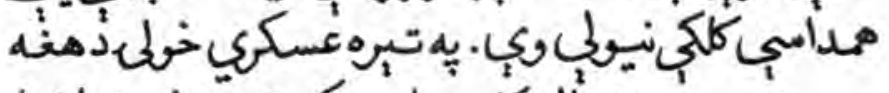

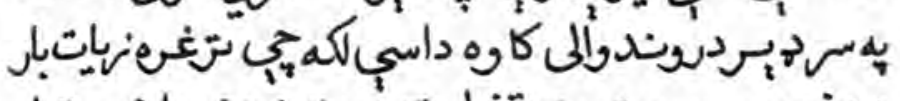

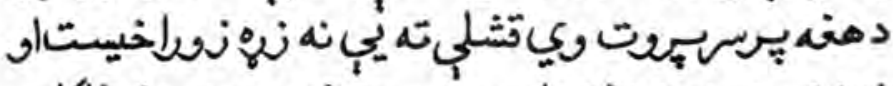

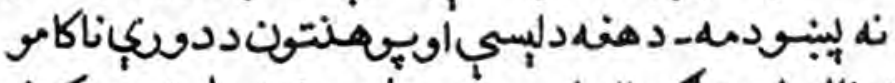

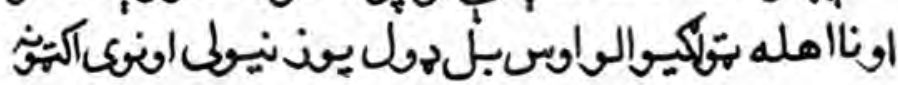




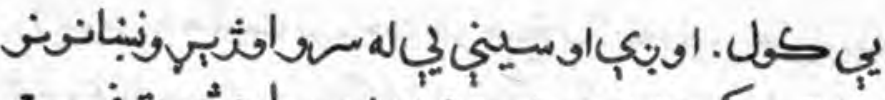

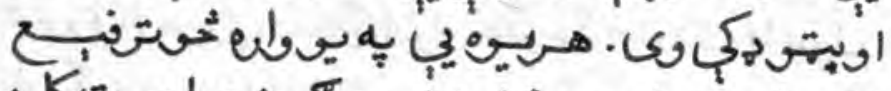

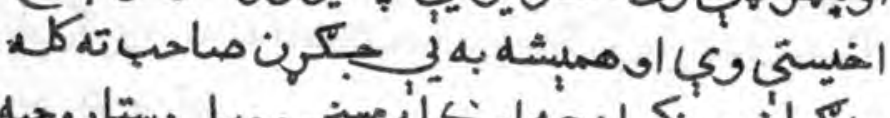

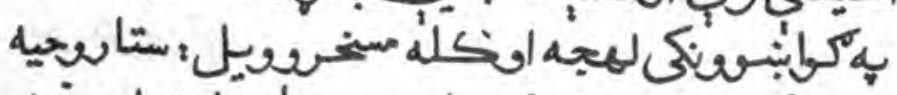

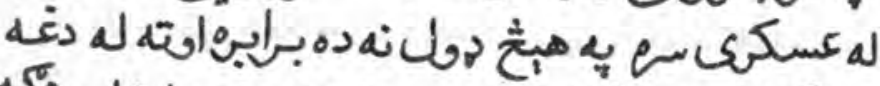

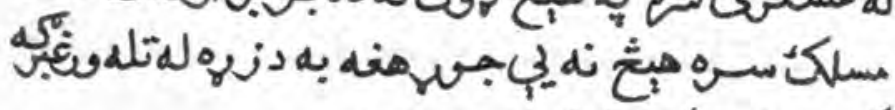

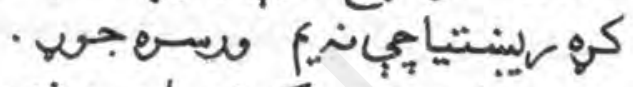

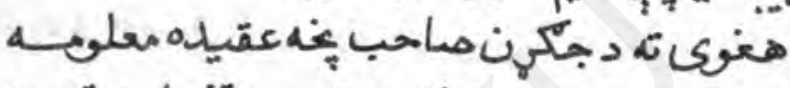

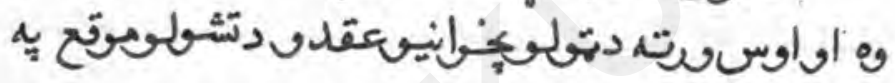

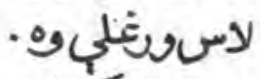

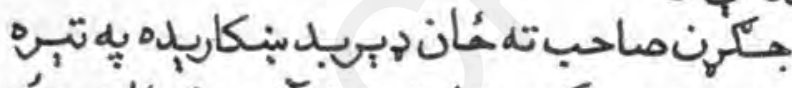

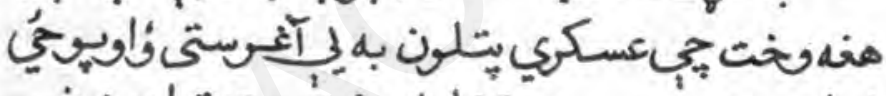

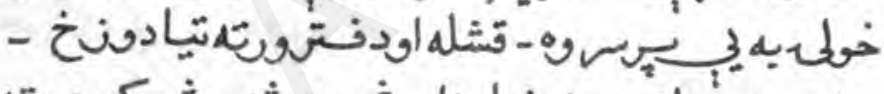

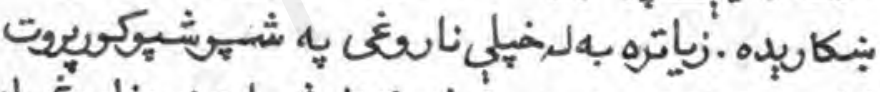

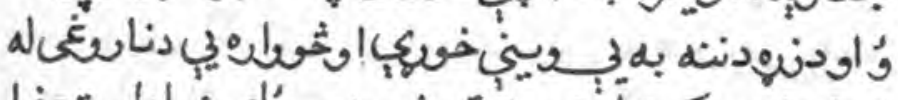

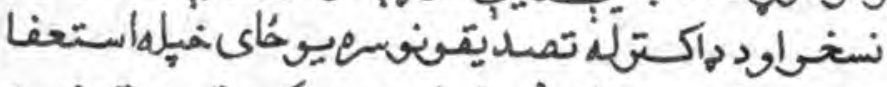

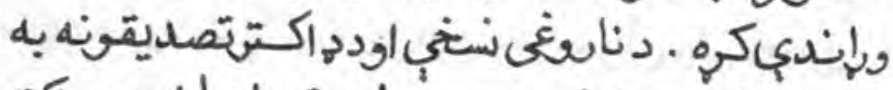

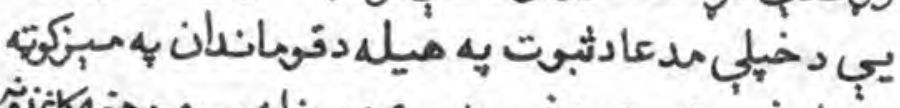

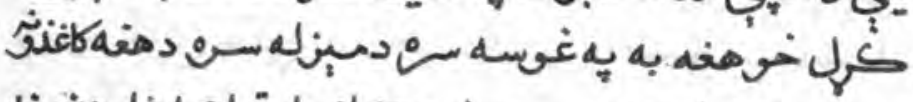

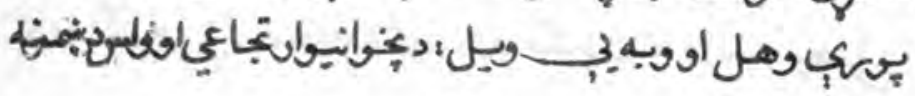




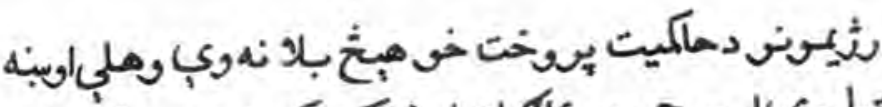

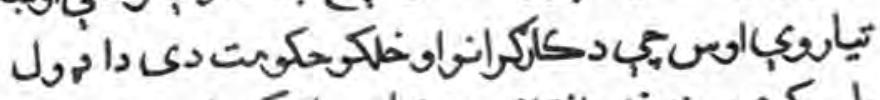

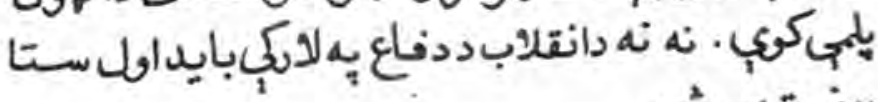

$$
\text { ويني تئيثيانيا. }
$$

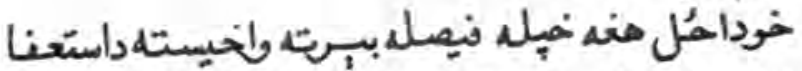

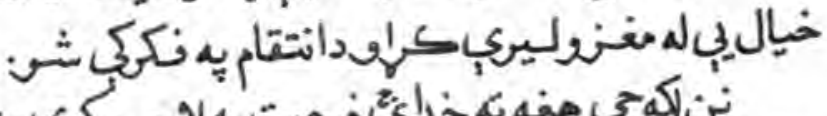

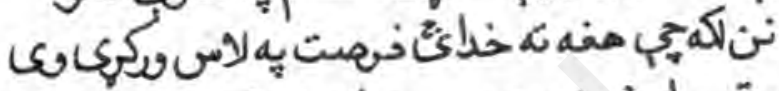

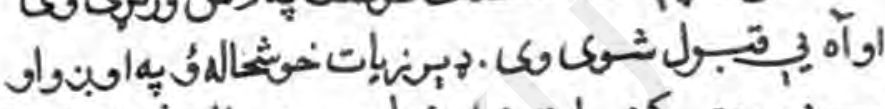

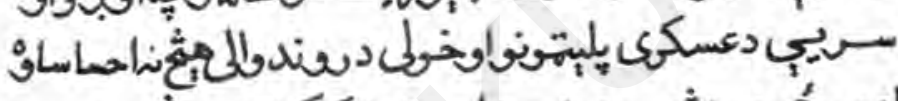

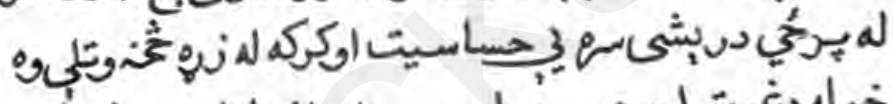

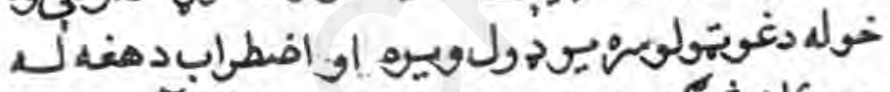

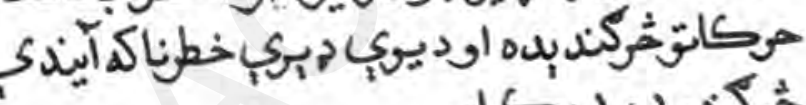

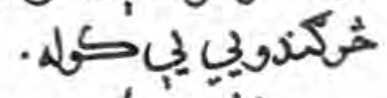

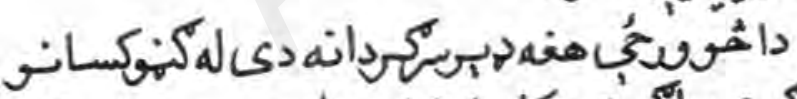

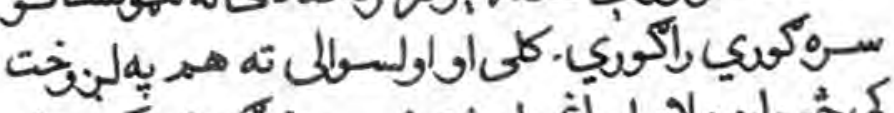

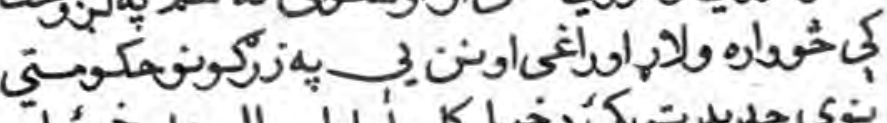

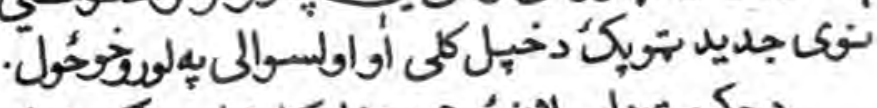

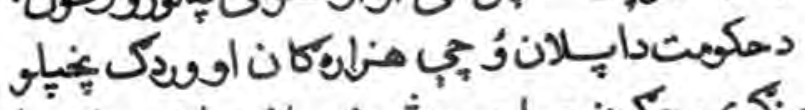
كي مجنَكي جكي

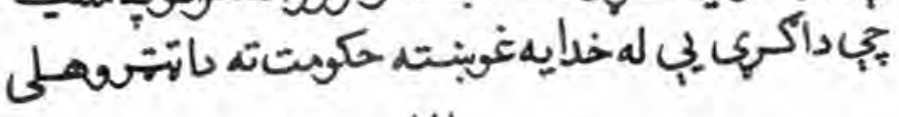




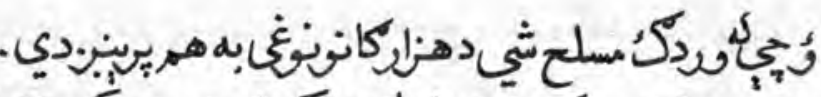

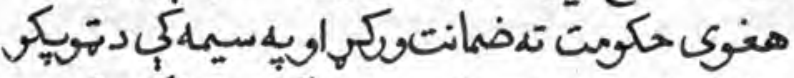

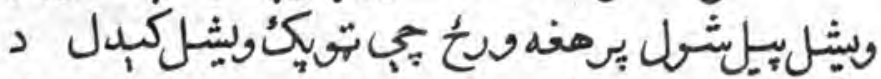

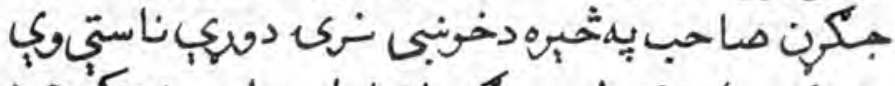

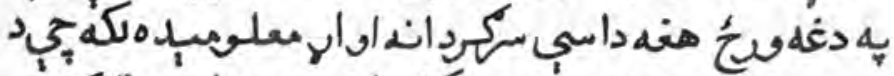

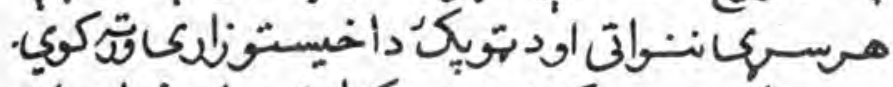

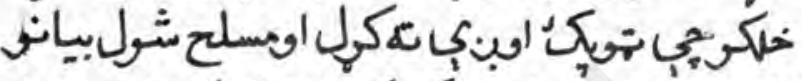

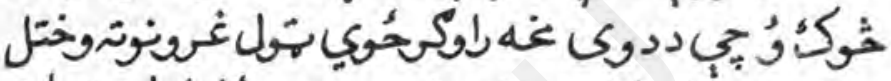

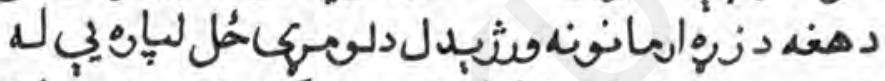

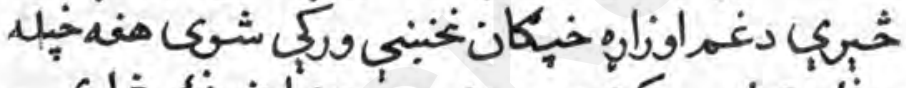

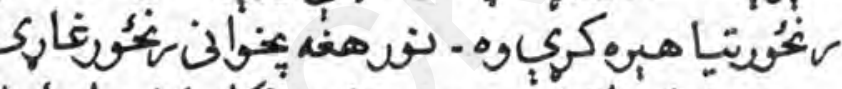

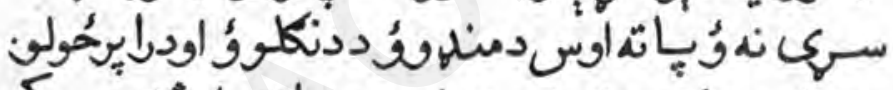

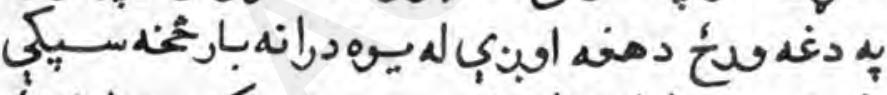

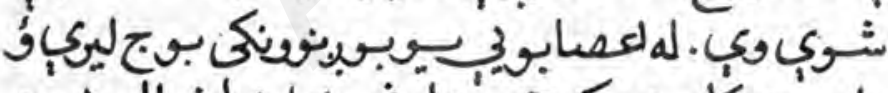

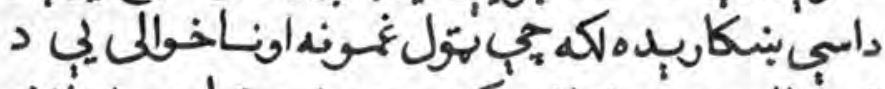

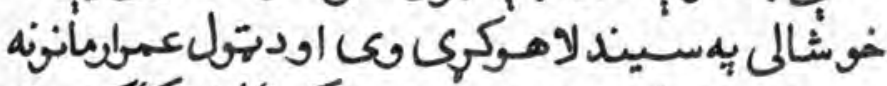

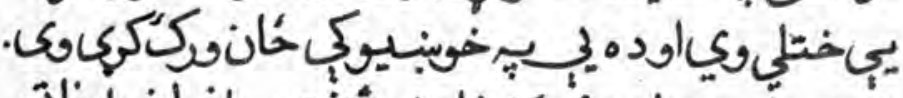

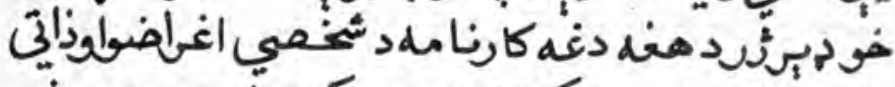

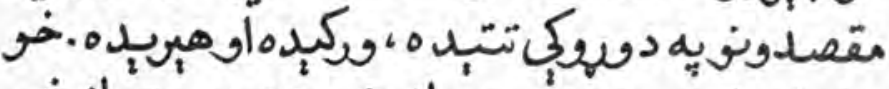

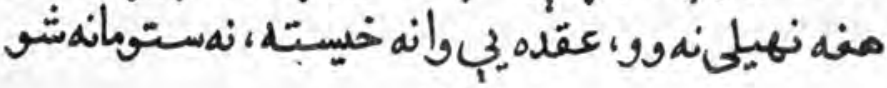




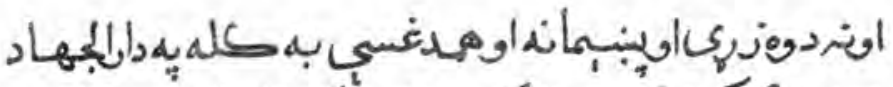

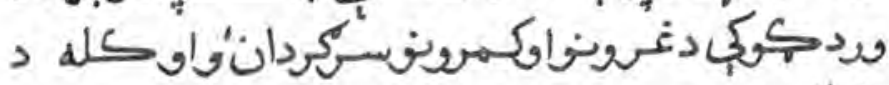

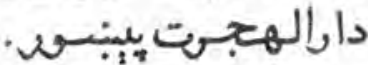

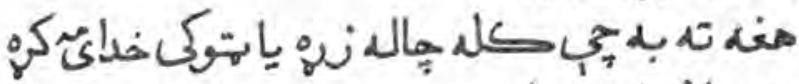

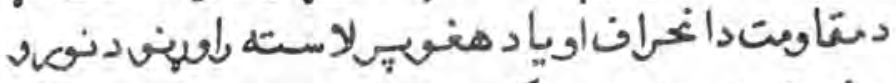

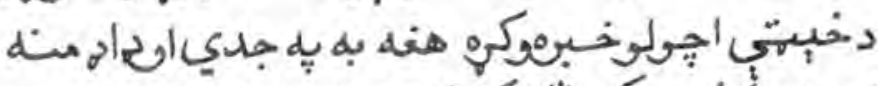

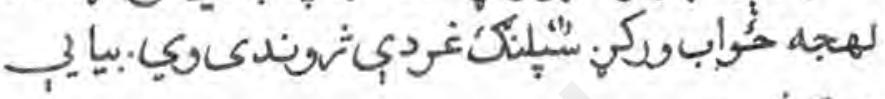

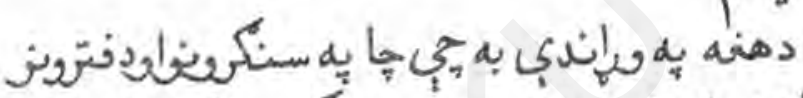

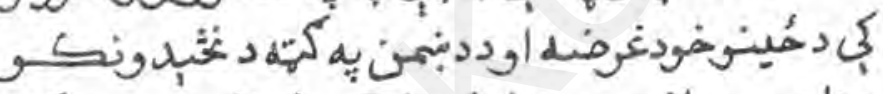

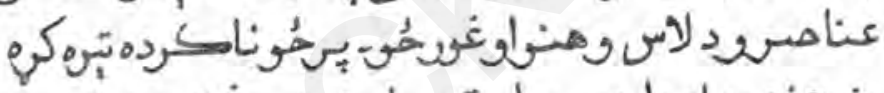

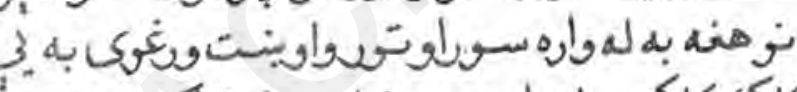

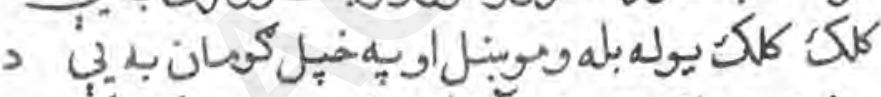

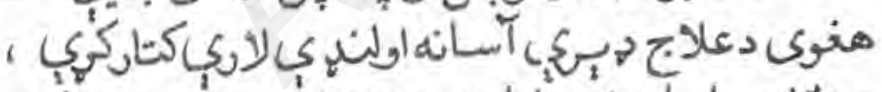

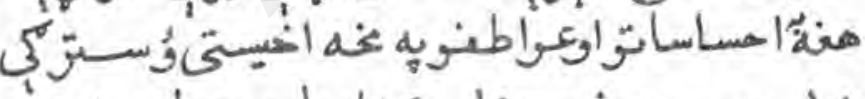

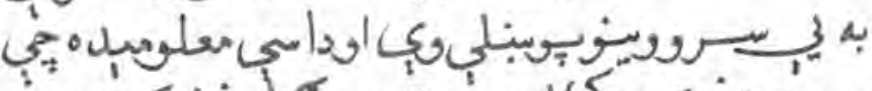

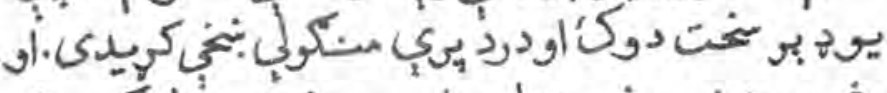

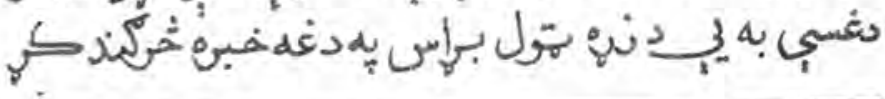

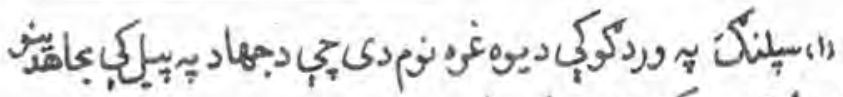
هلته مؤتَت مككنرين درليودل. 


\section{:..........}

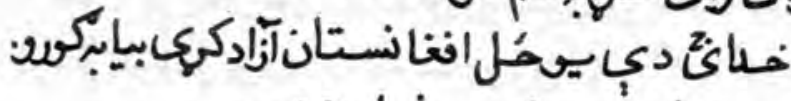

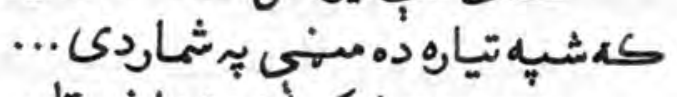

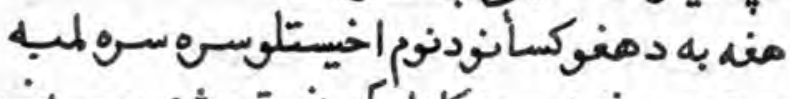

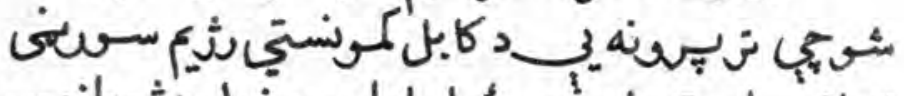

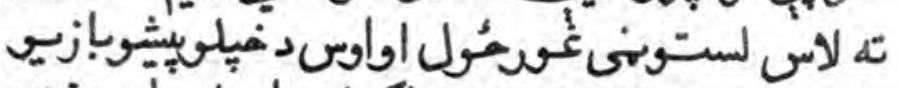

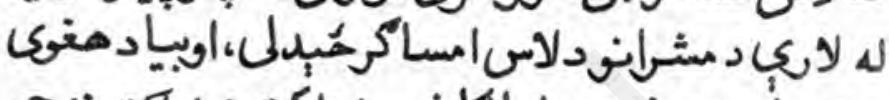

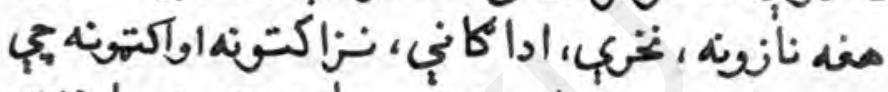

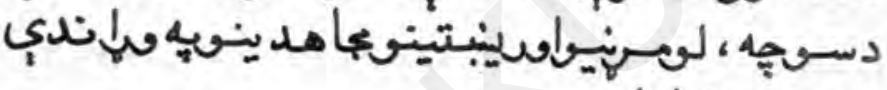

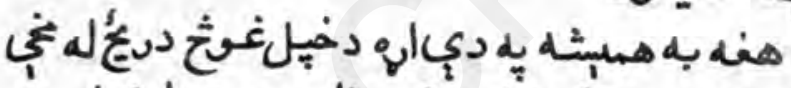

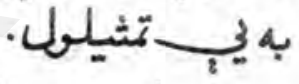

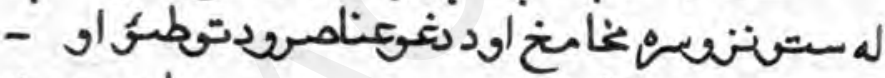

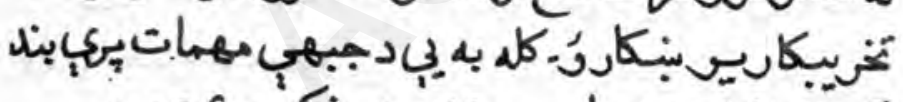

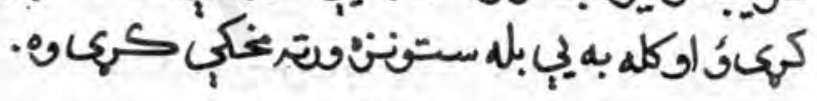

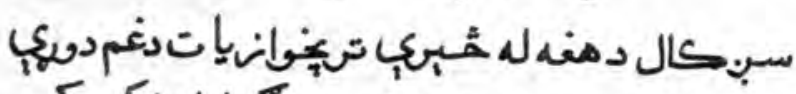

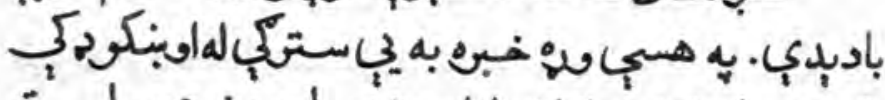

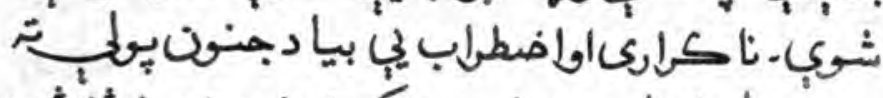

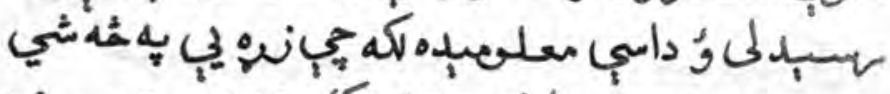

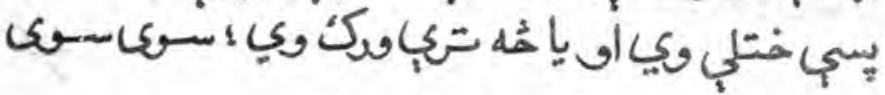




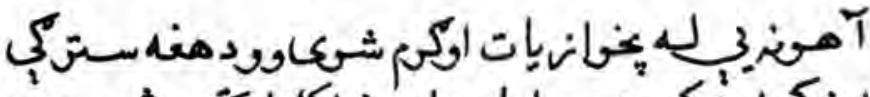

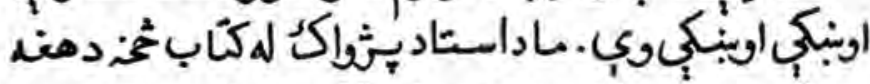

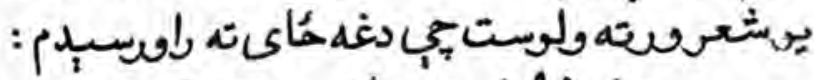

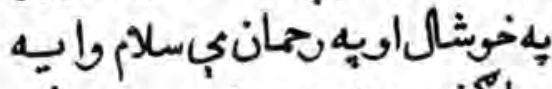

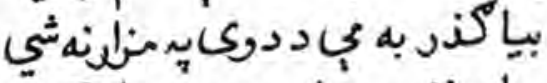

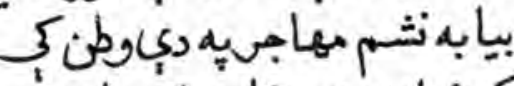

$$
\begin{aligned}
& \text { كيخيله دوى بحتابح دانفسارنهشي }
\end{aligned}
$$

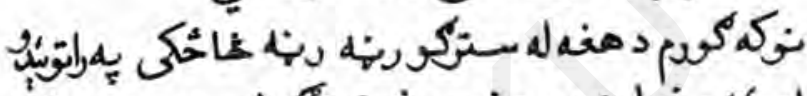

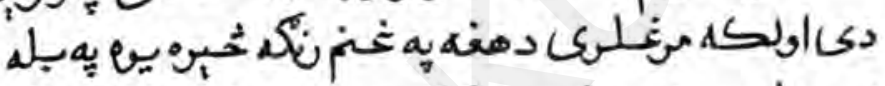

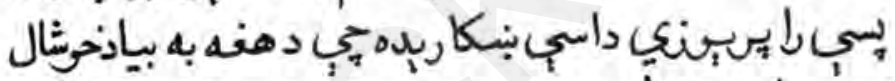

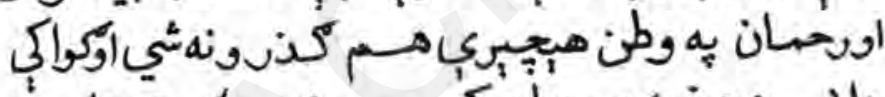

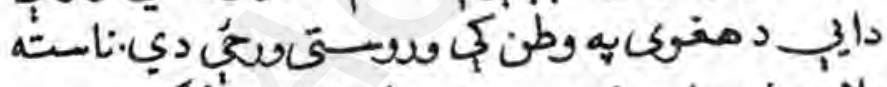

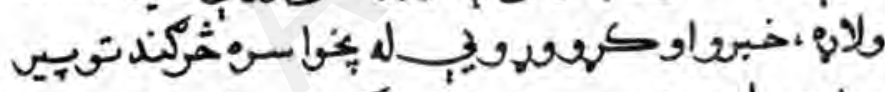

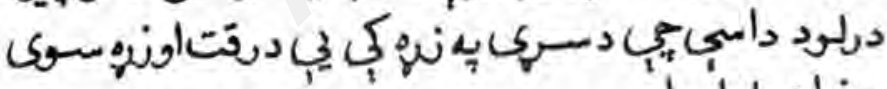
جذبات إيارول.

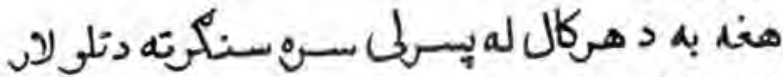

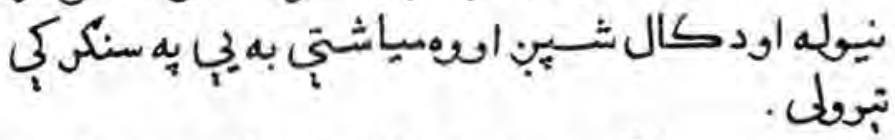

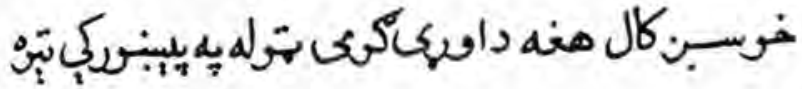




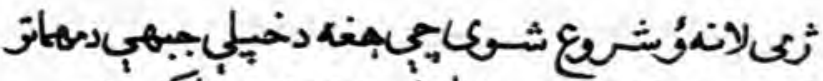

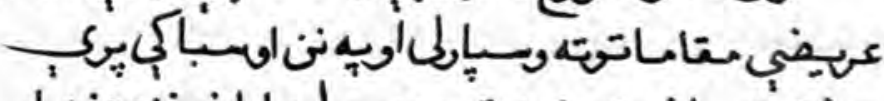

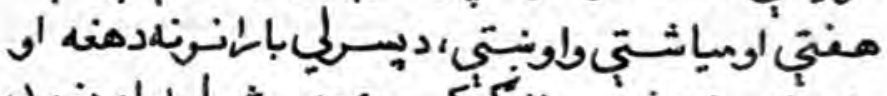

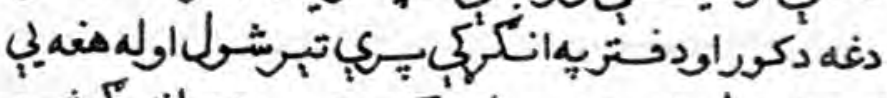

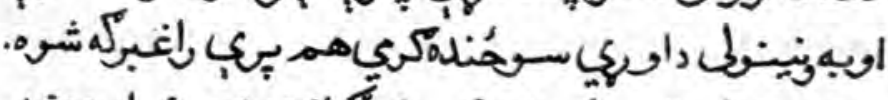

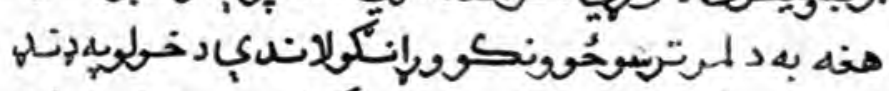

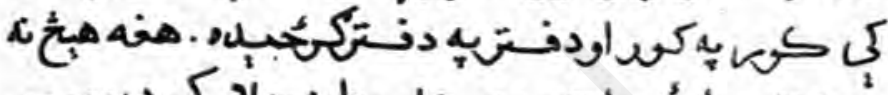

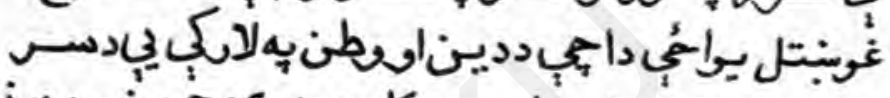

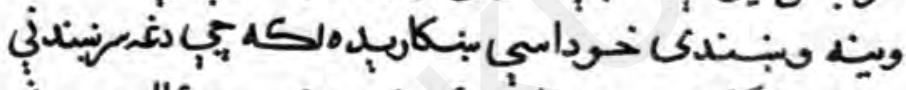

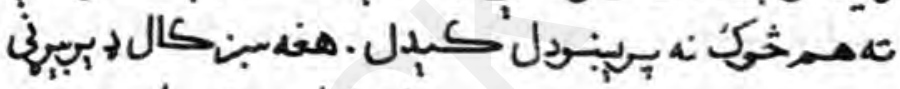

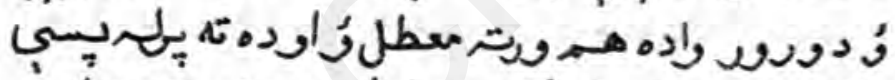

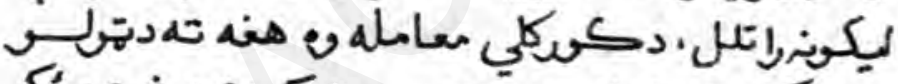

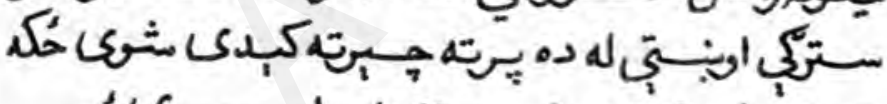

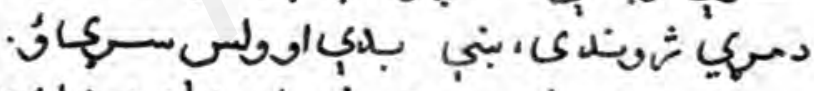

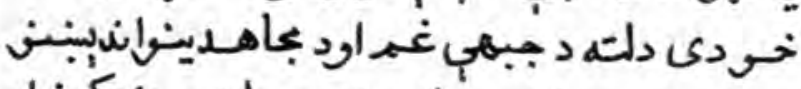

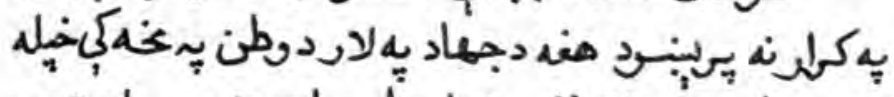

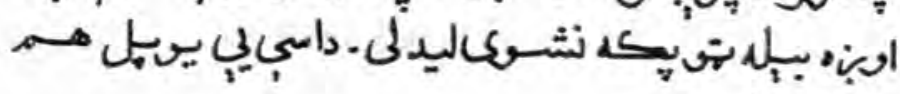
شتصائاخيستى

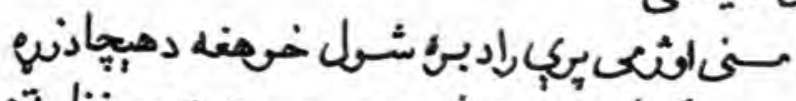

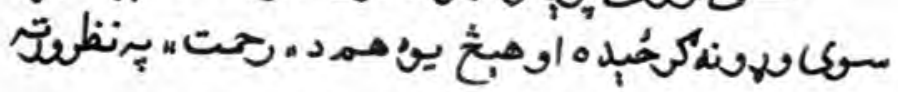




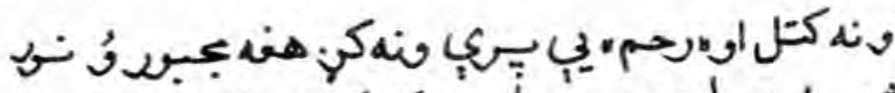

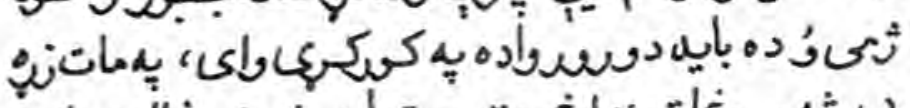

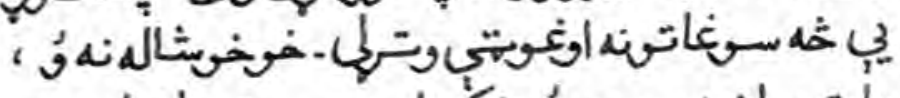

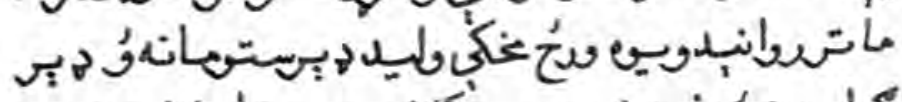

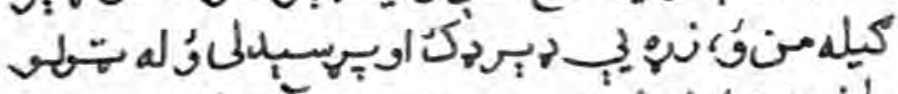

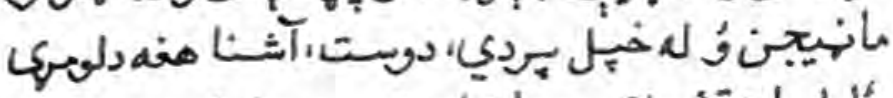

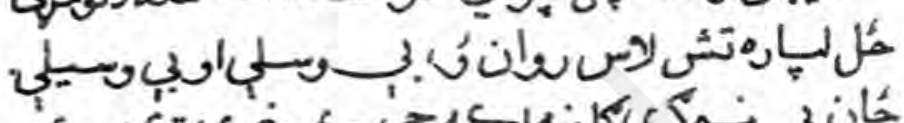
حان

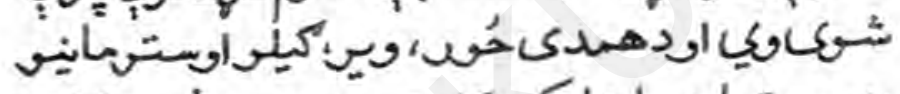

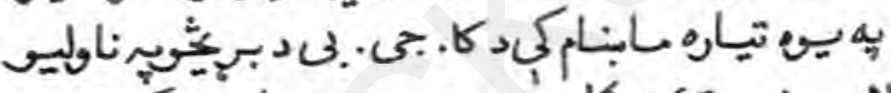

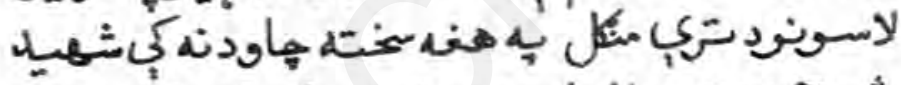

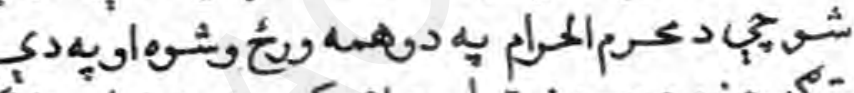

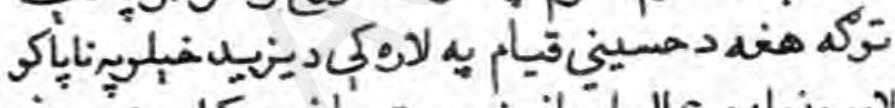

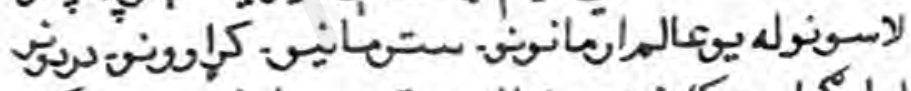

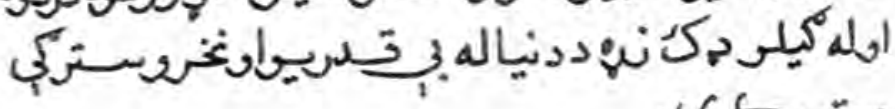

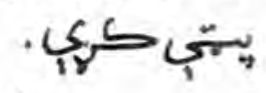

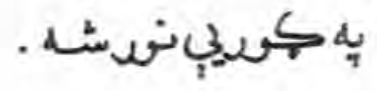




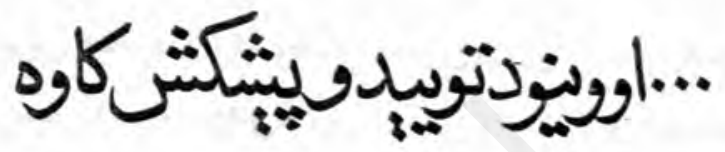

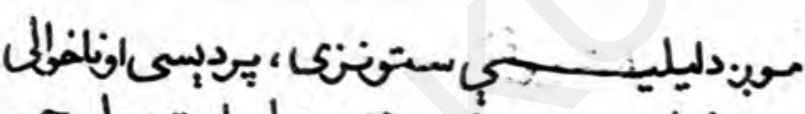

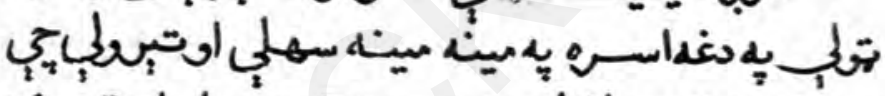

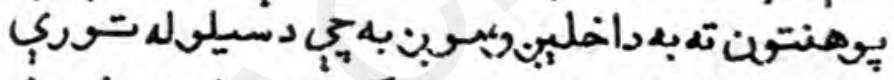

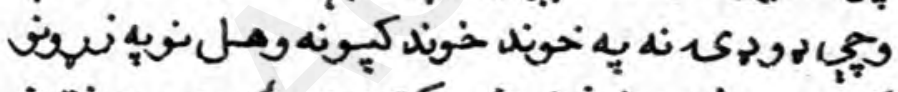

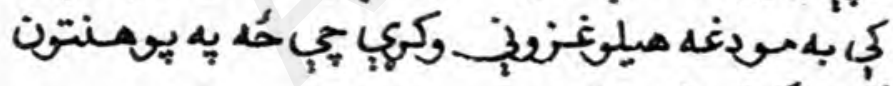

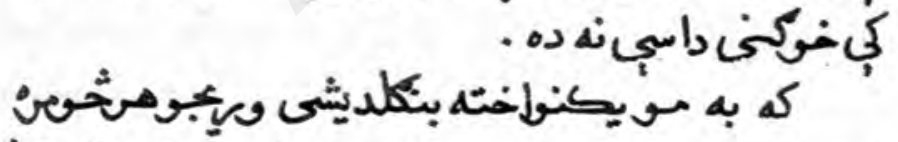

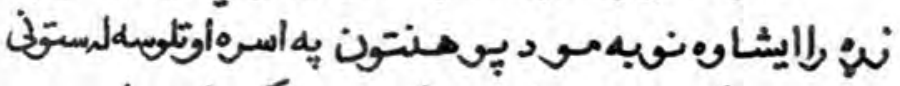

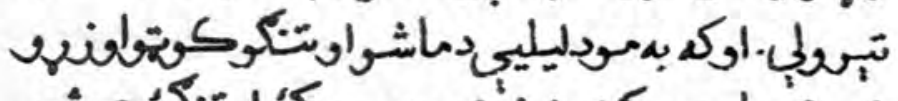

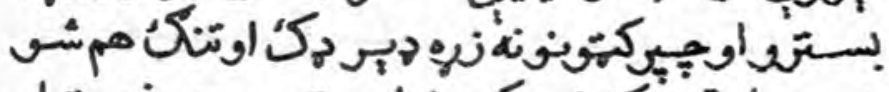

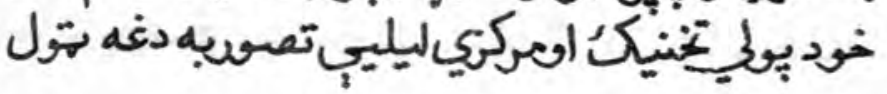




$$
\text { التهدزنغمر فرويكحُول. }
$$

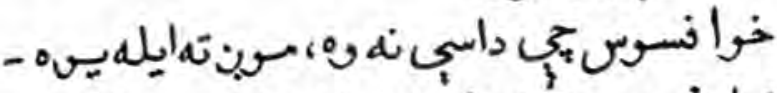

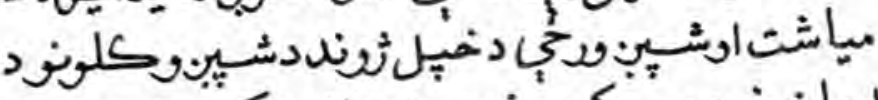

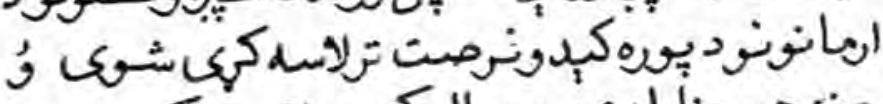

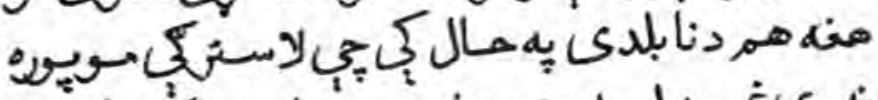

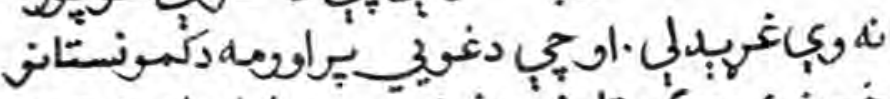

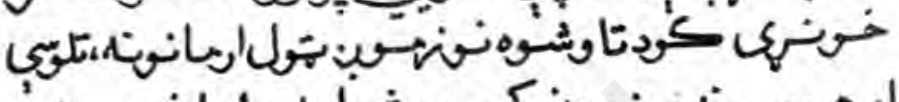

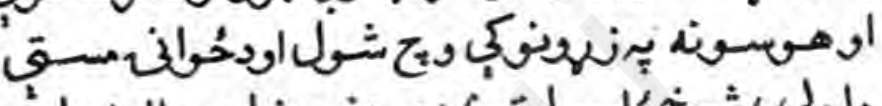

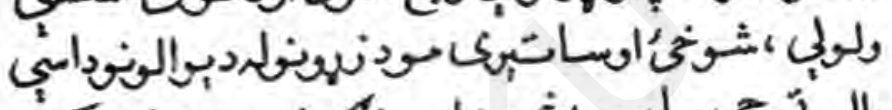

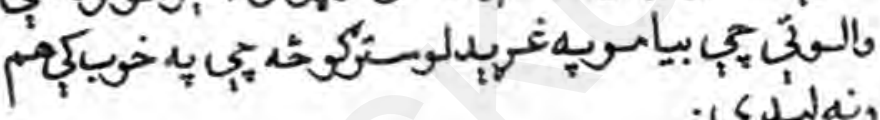

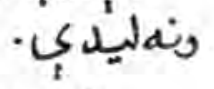

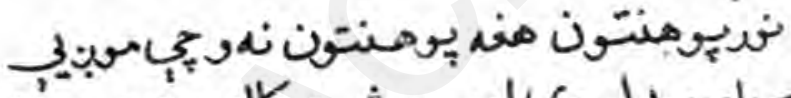

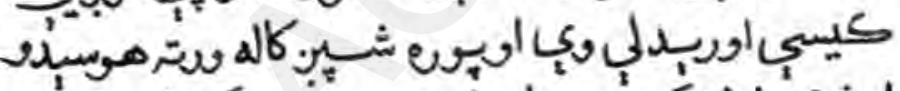

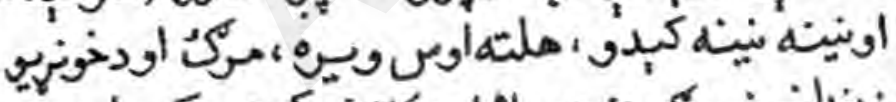

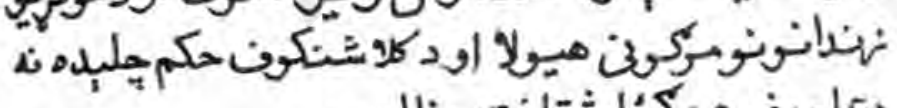

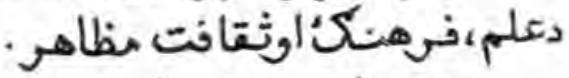

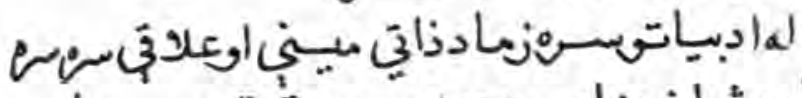

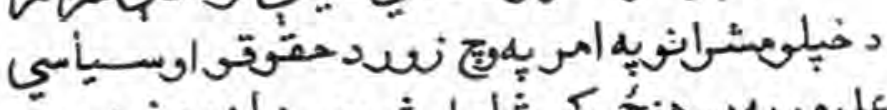

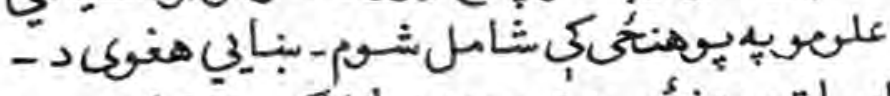

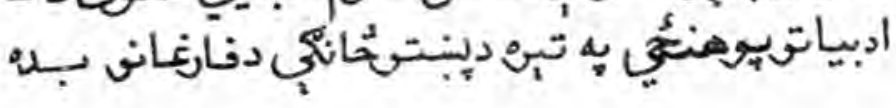




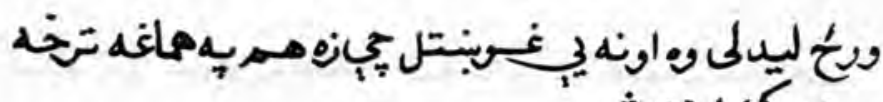

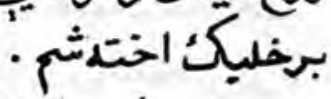

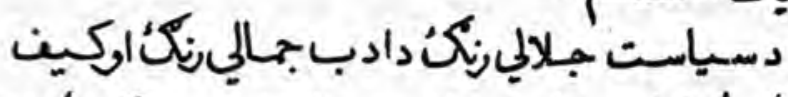

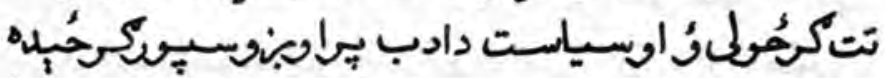

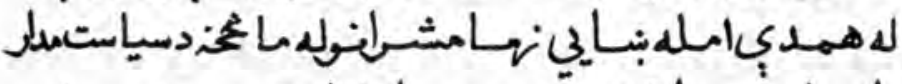

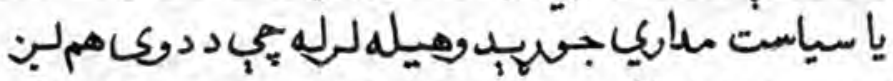

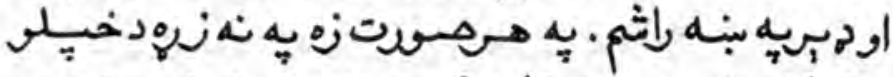

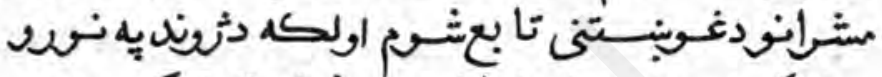

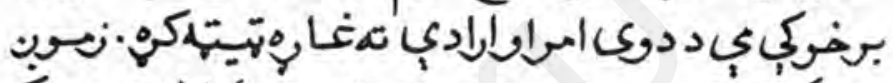

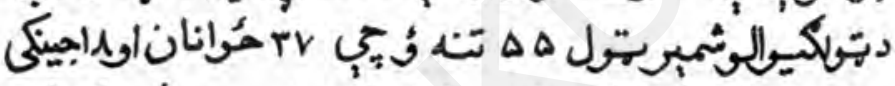

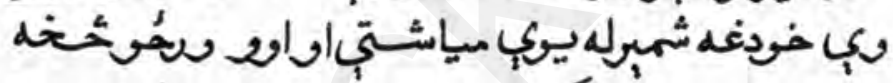

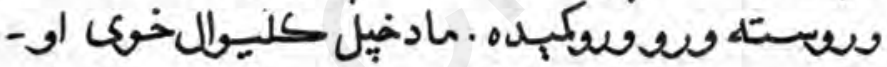

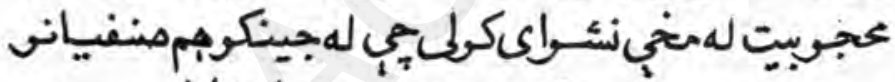

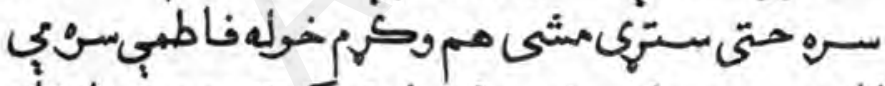

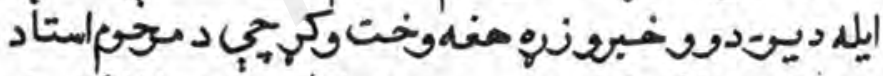

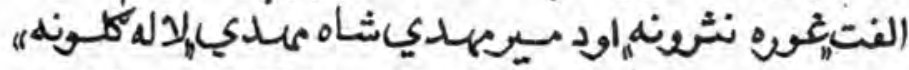

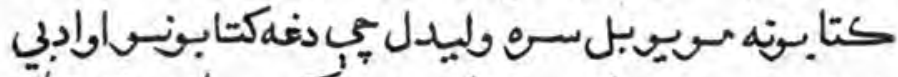

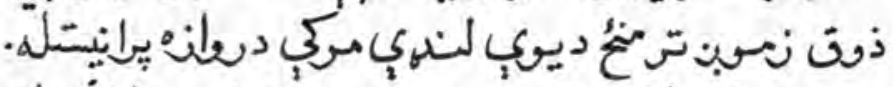

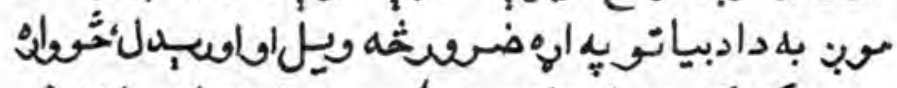

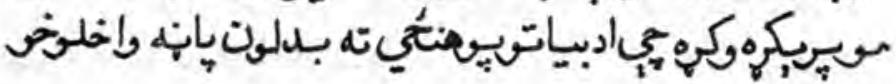




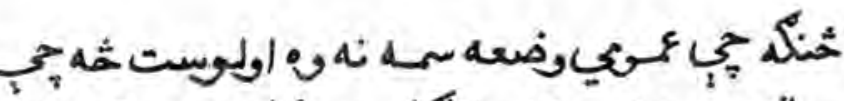

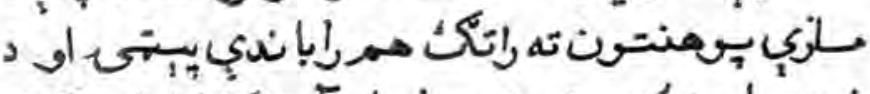

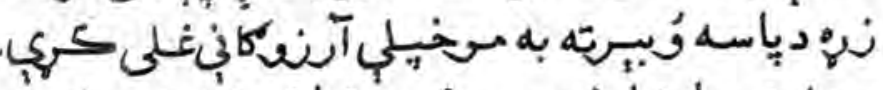

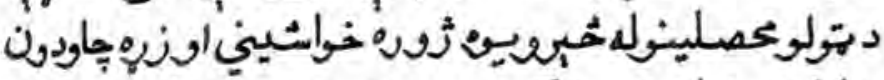

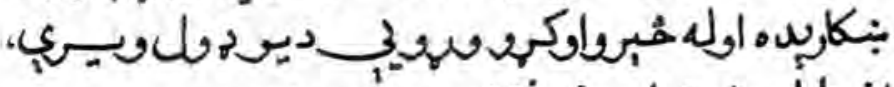

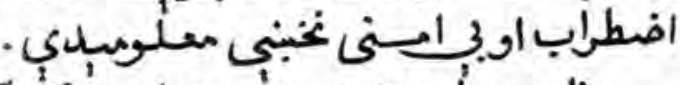

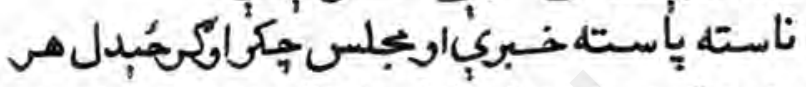

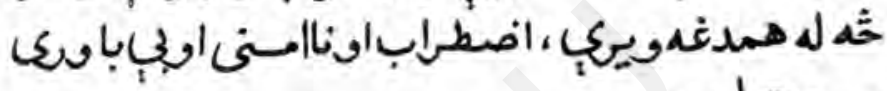

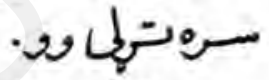

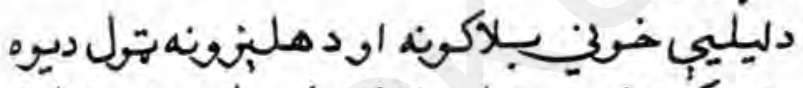

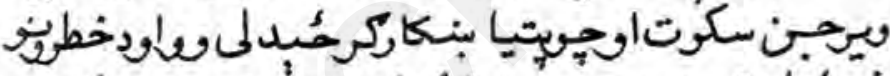

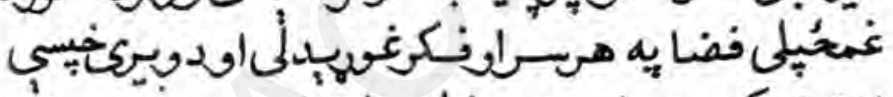

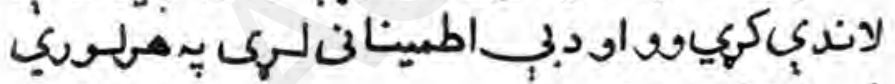

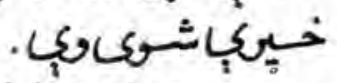

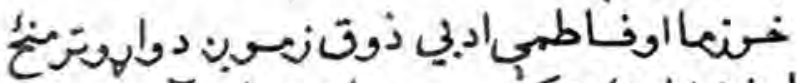

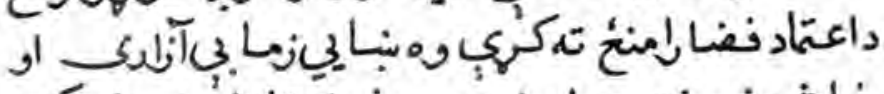

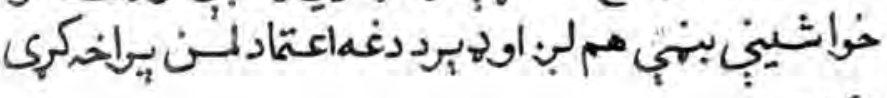
كي

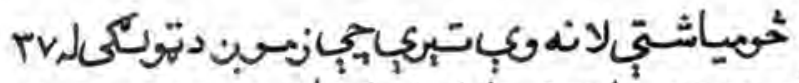

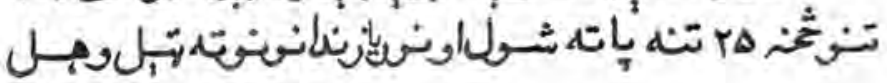




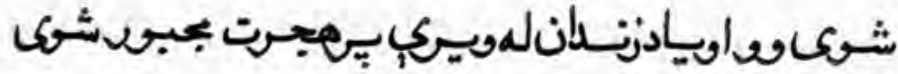

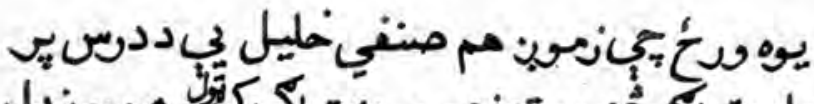

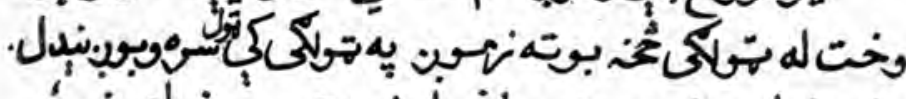

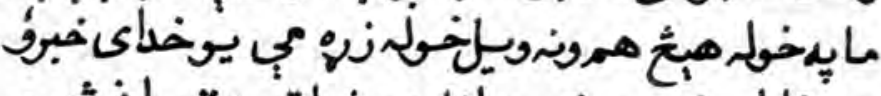

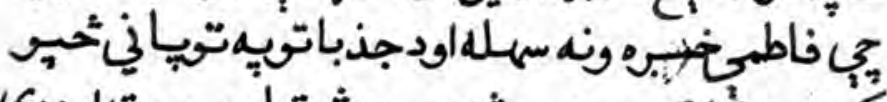

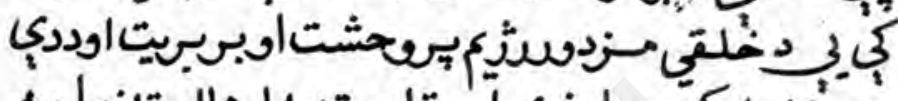

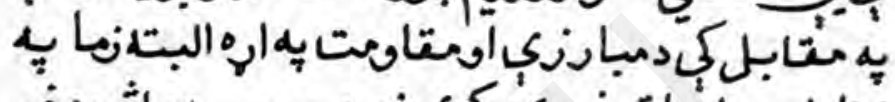

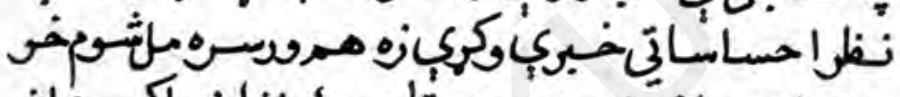

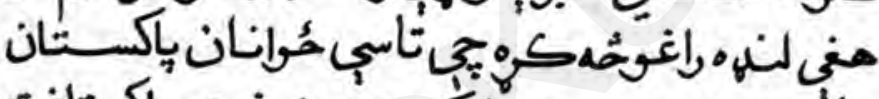

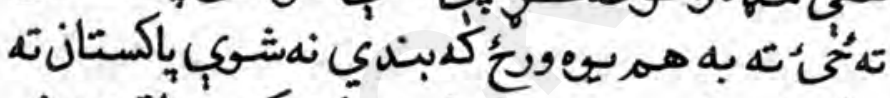

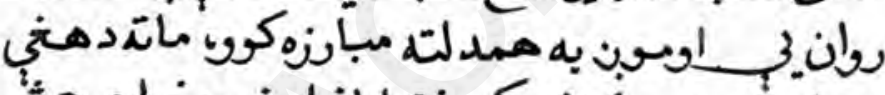

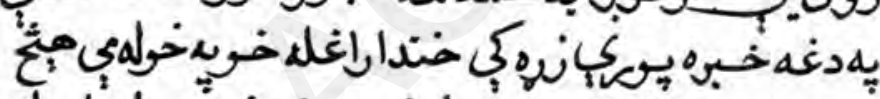

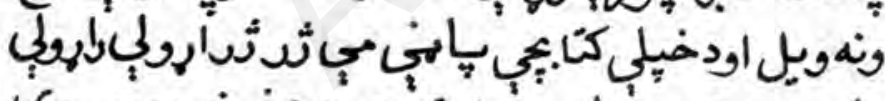

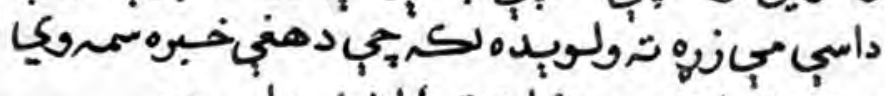

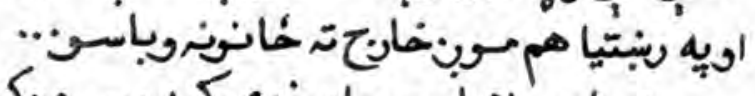

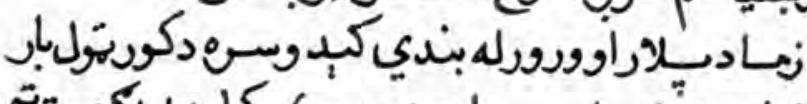

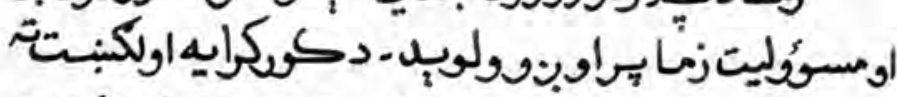

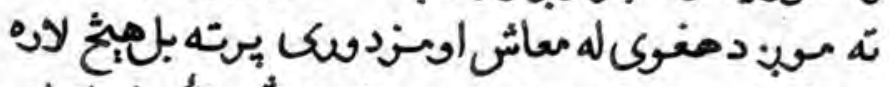

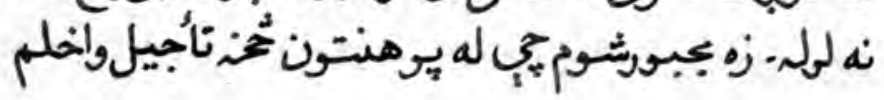


اودمعاشيياكولولاريلتزمباديلارديوهدوست يه

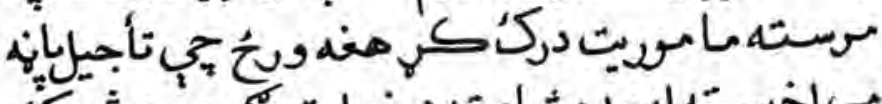

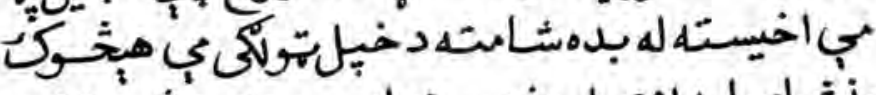

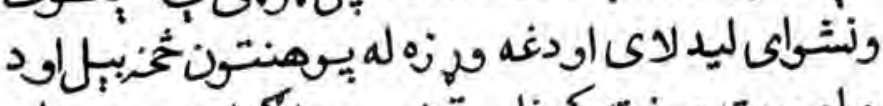

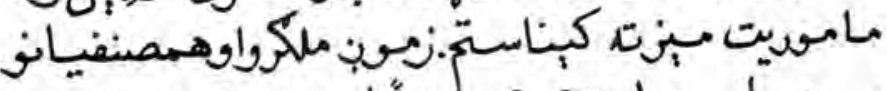

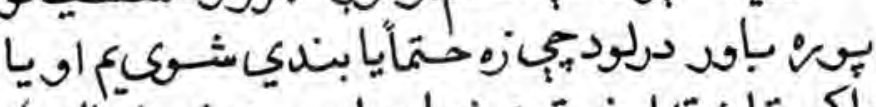

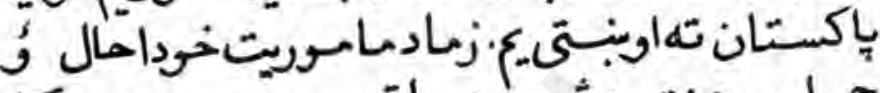

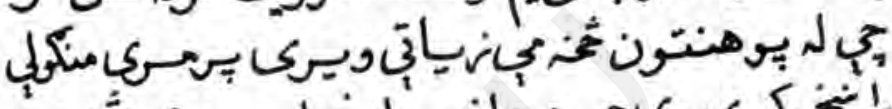

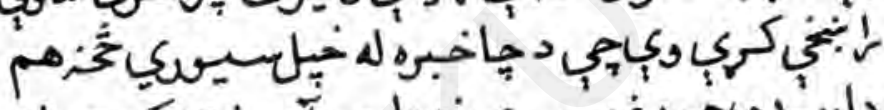

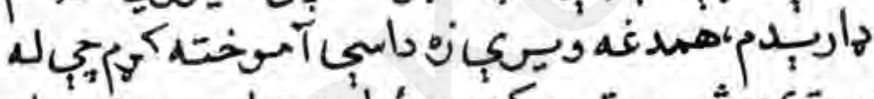

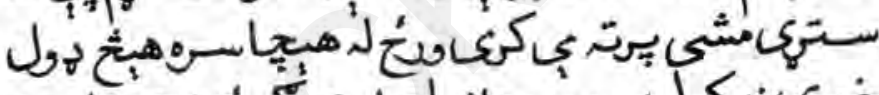

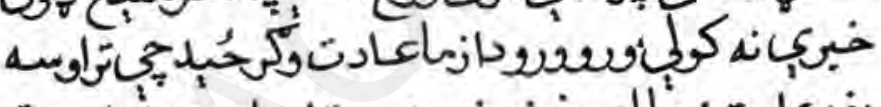

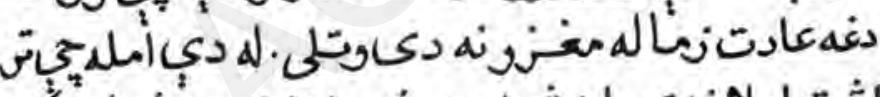

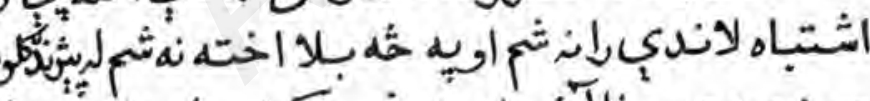

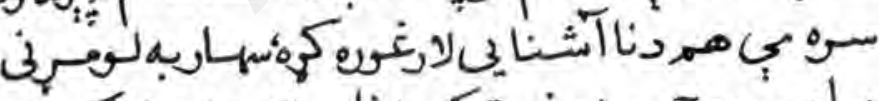

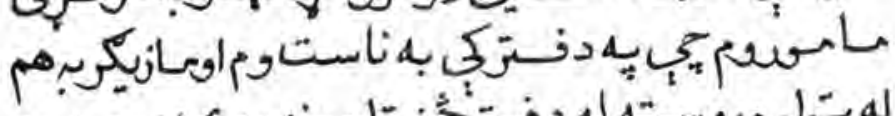

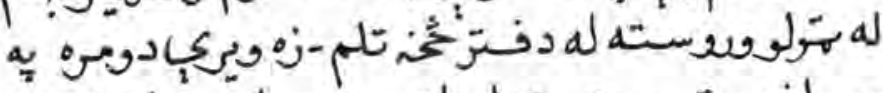

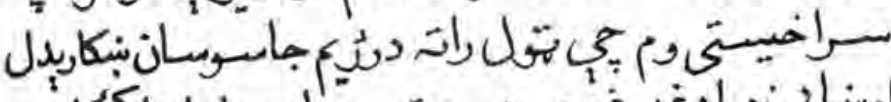

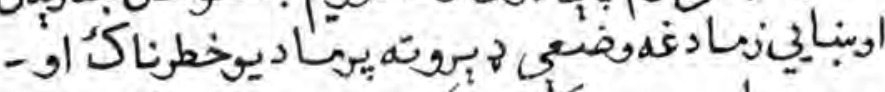

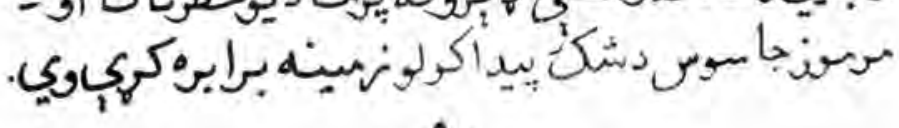




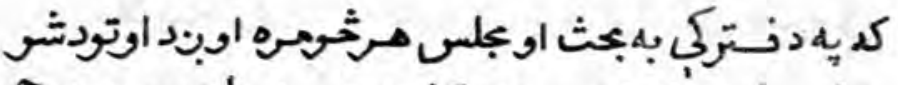

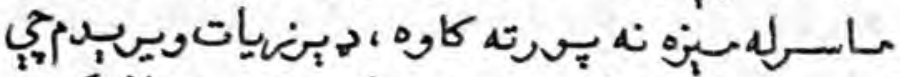

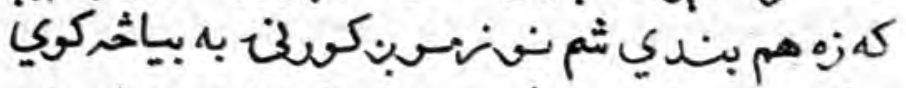

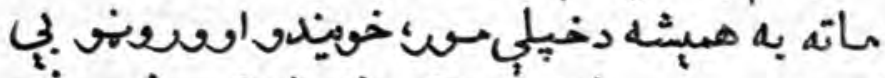

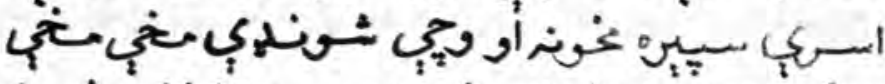

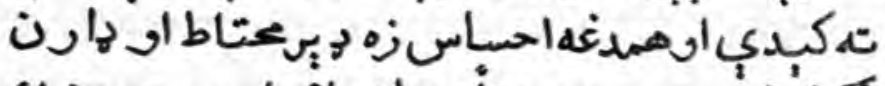

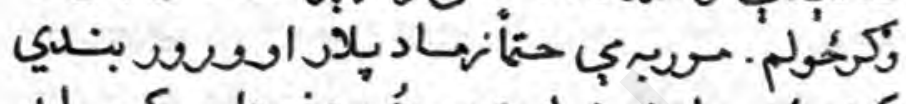

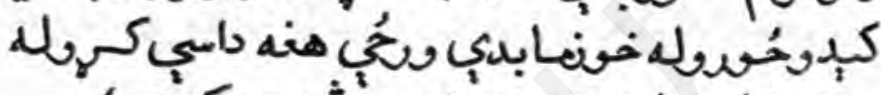

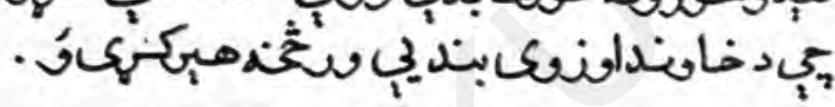
* $\Rightarrow$

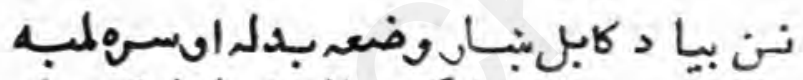

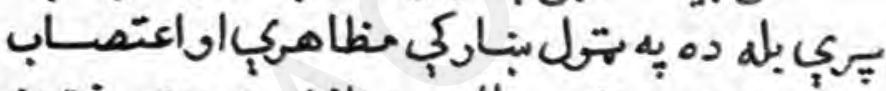

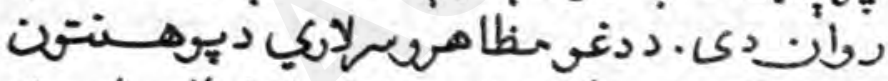

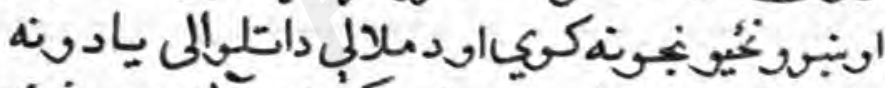

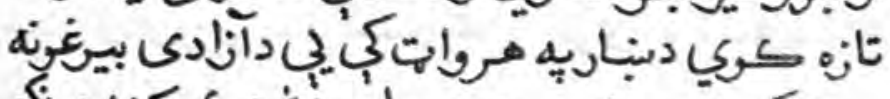

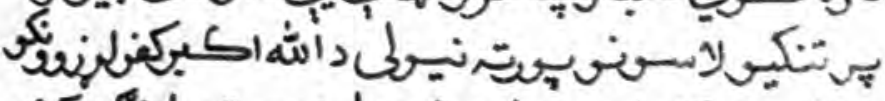

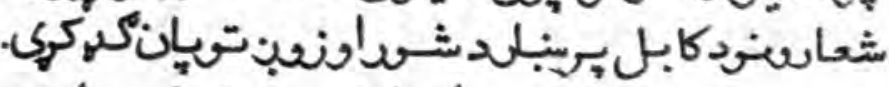

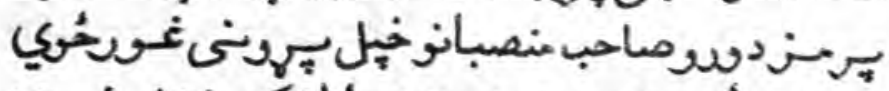

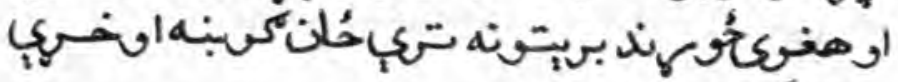

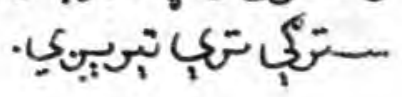




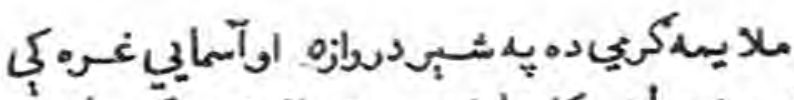

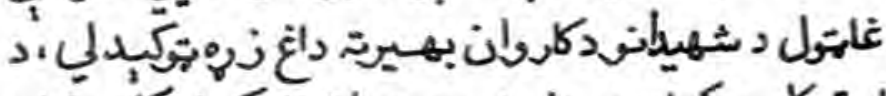

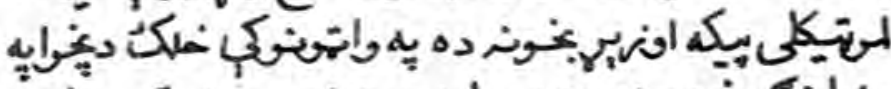

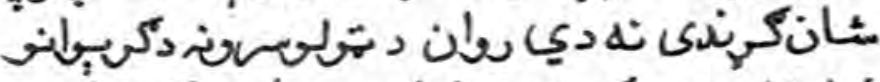

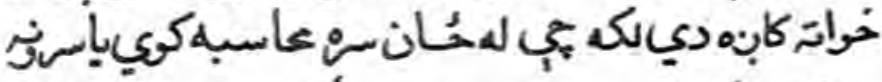

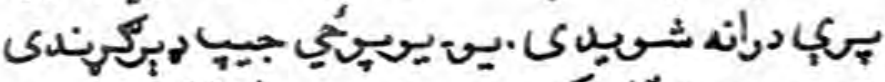

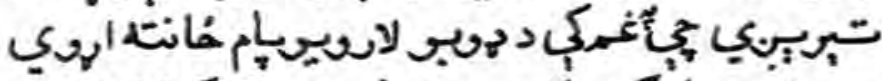

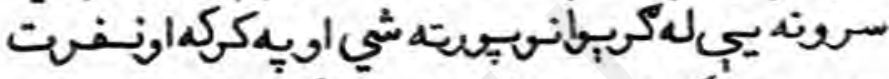

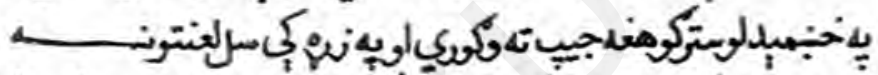

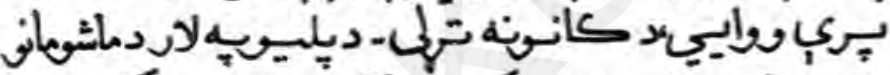

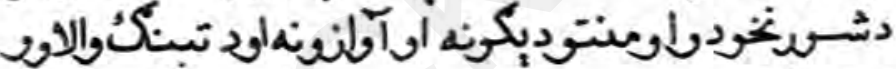

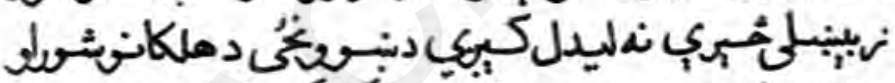

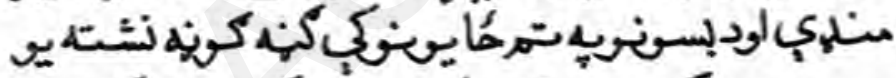

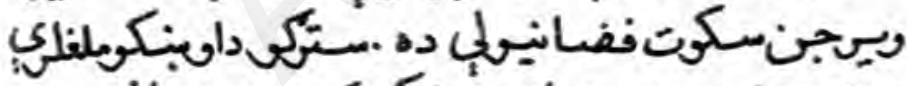

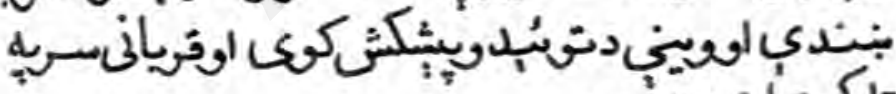

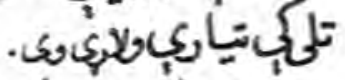

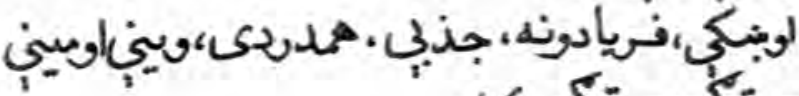

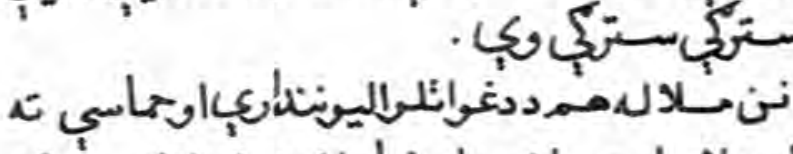

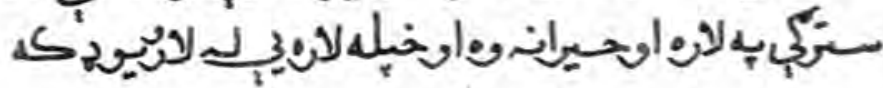




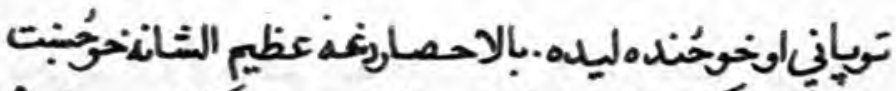

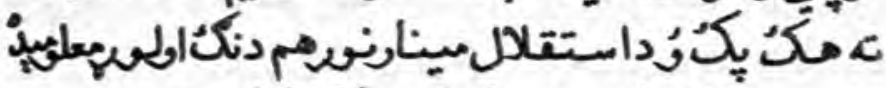

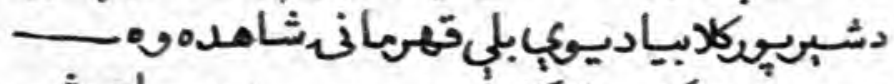

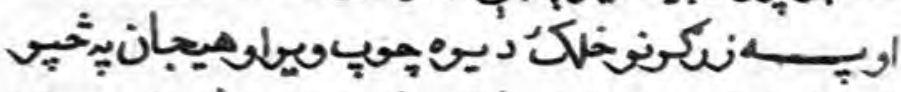

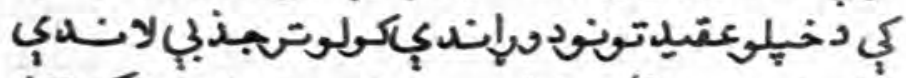

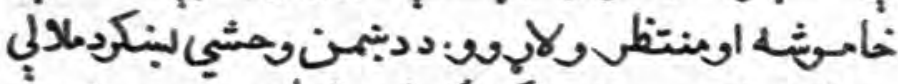

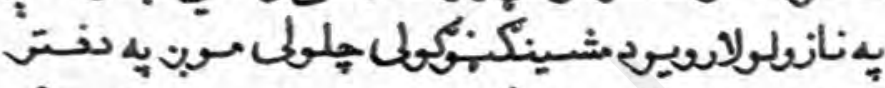

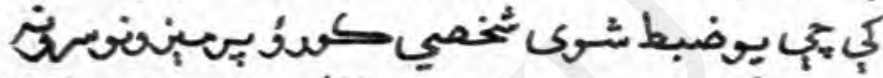

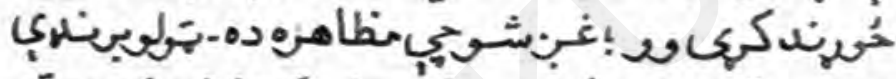

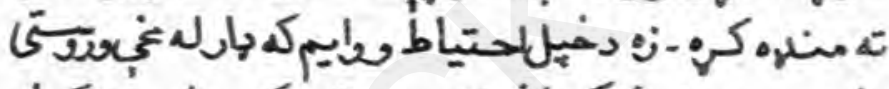

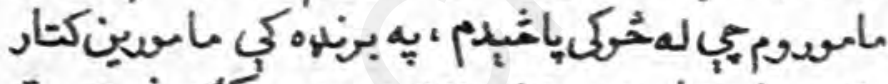

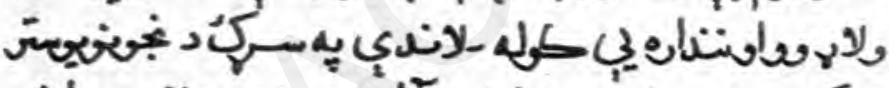

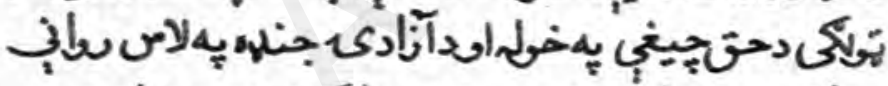

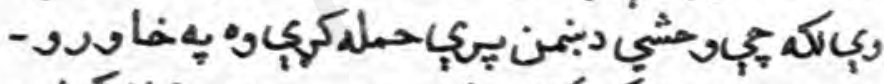

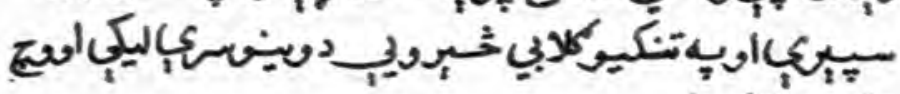
خايِنَحُملبدل.

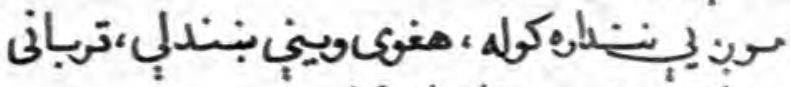

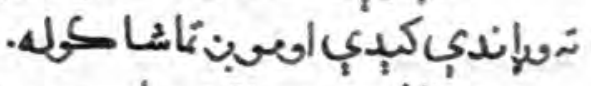

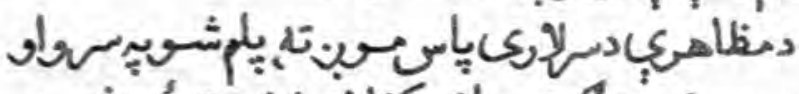

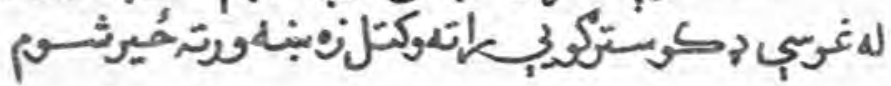




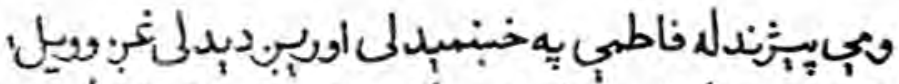

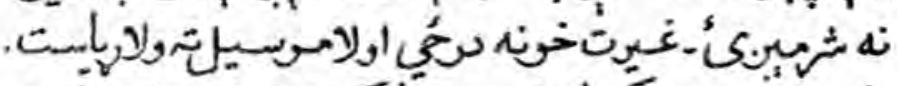

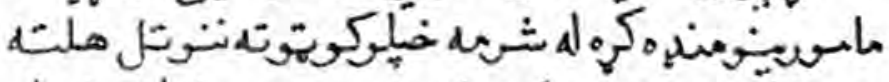

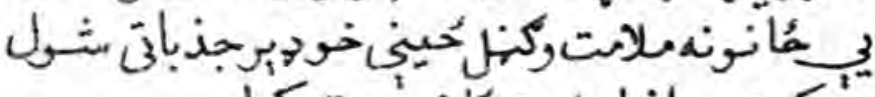

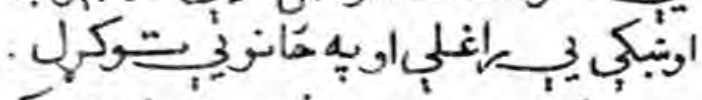

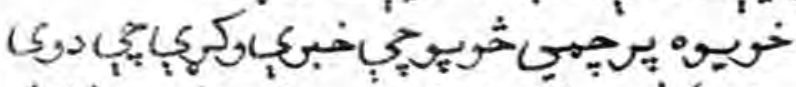

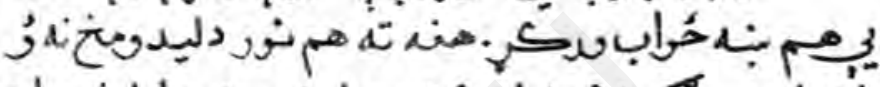

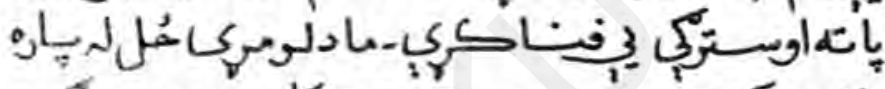

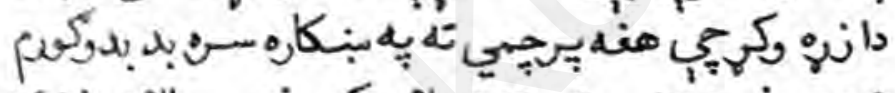

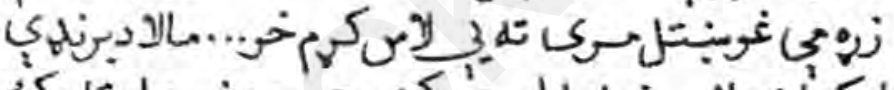

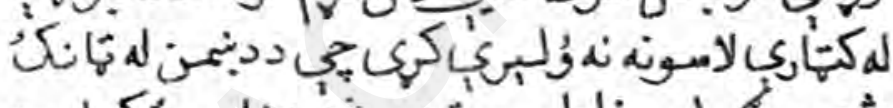

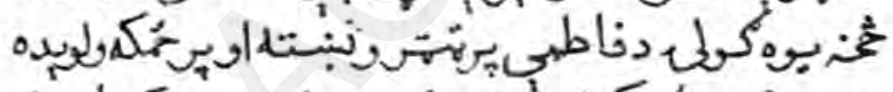

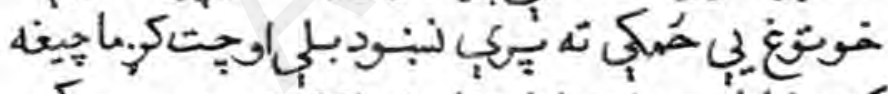

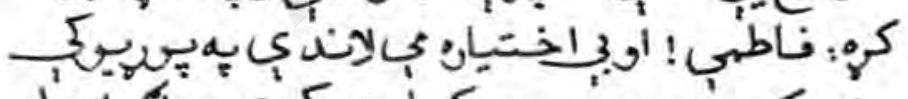

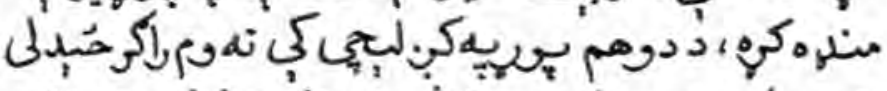

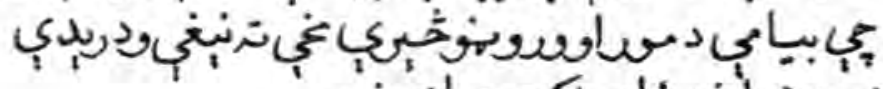

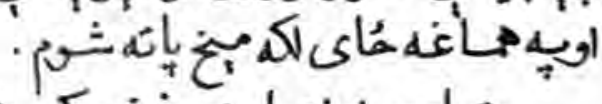

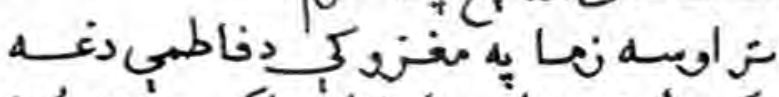

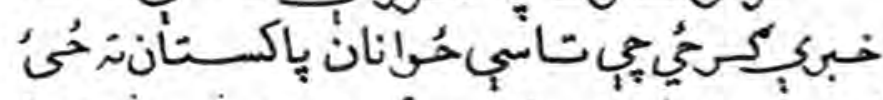

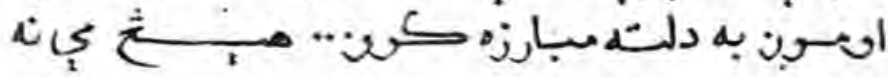




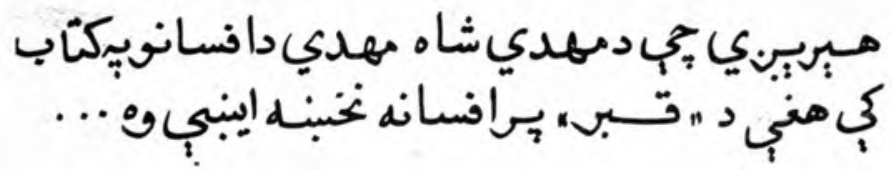

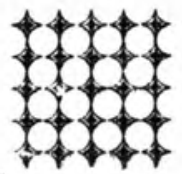


pe 


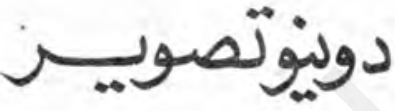

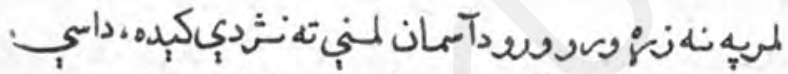

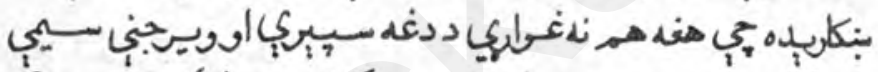

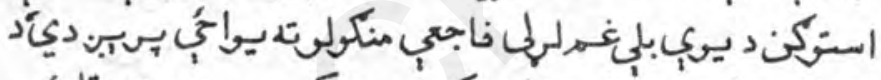

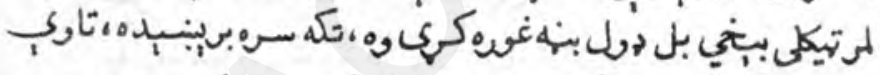

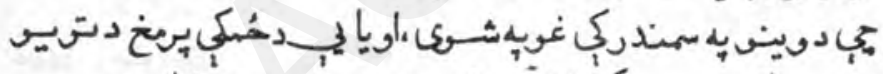

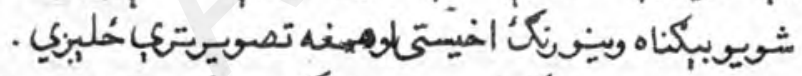

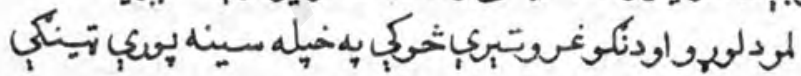

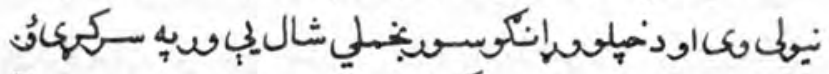

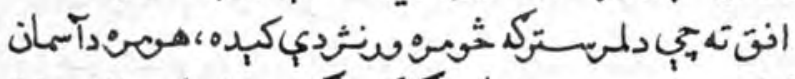

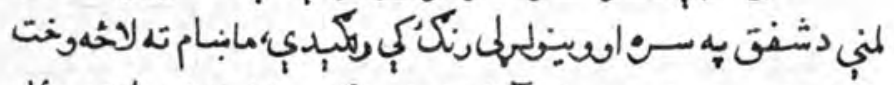

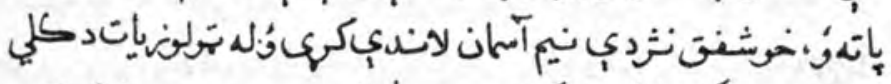

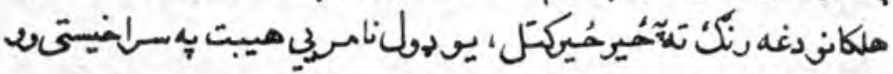




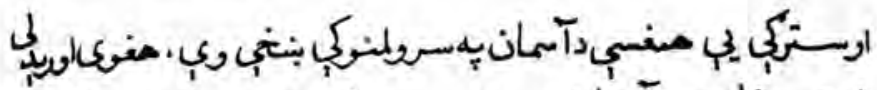

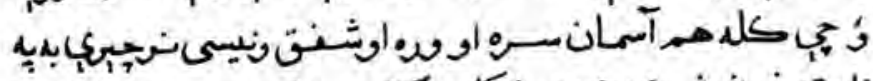

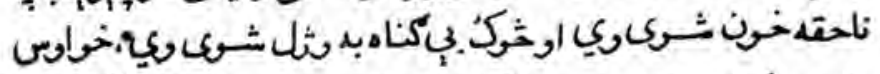

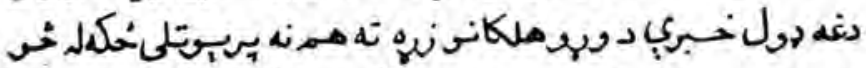

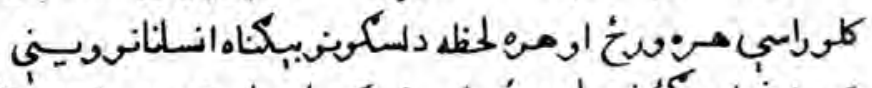

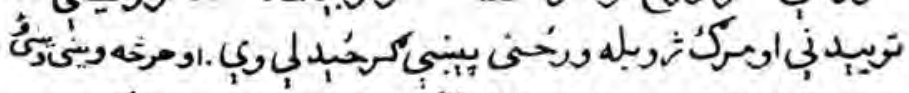

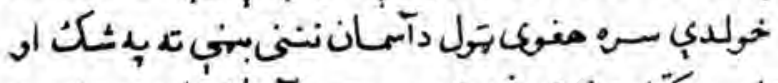

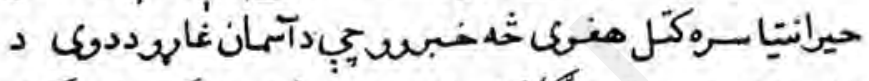

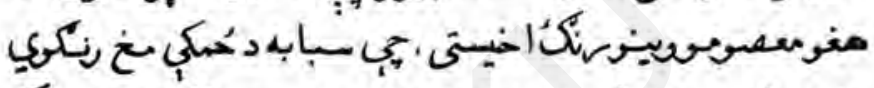

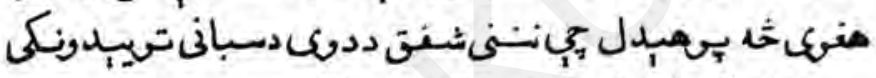

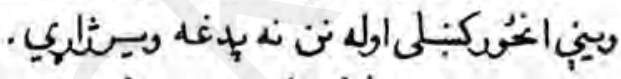

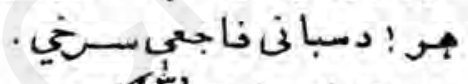

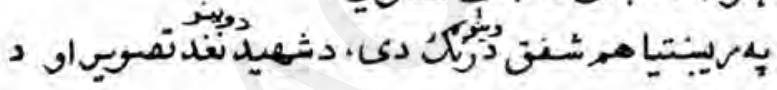
هغ وبيواغخون.

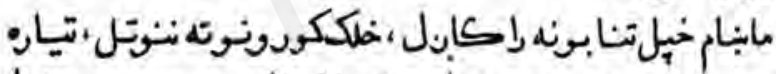

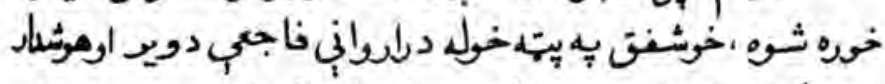

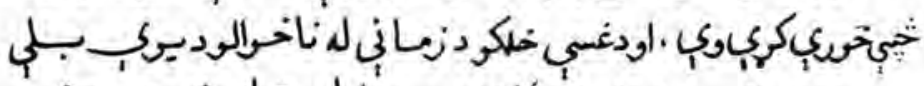

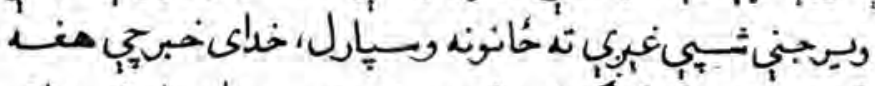

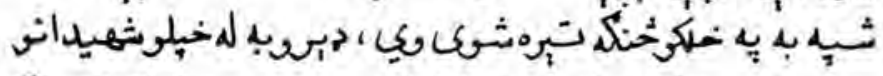

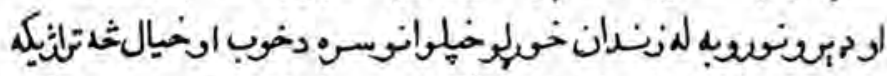

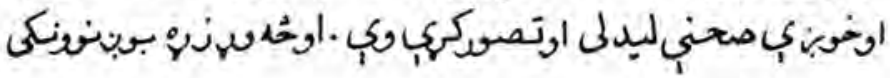




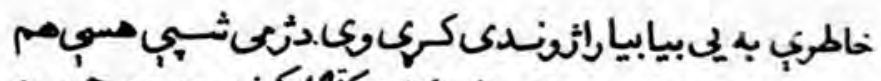

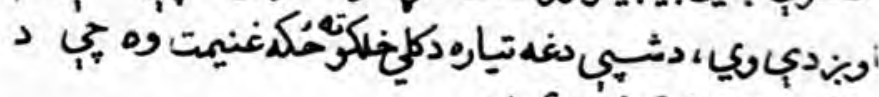

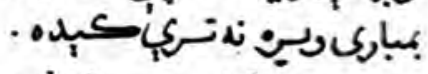

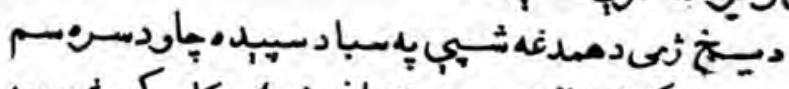

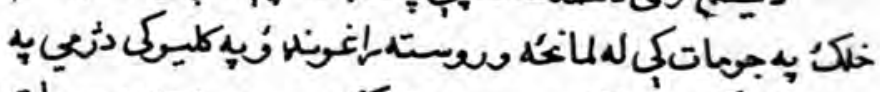

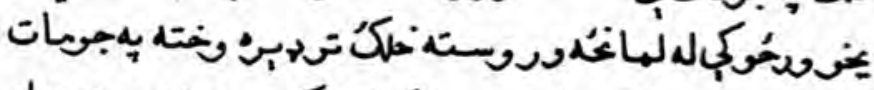

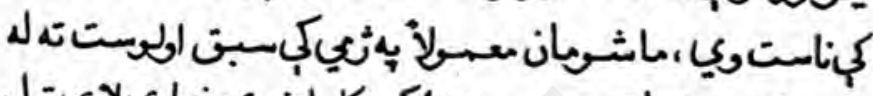

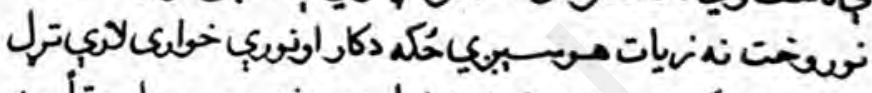

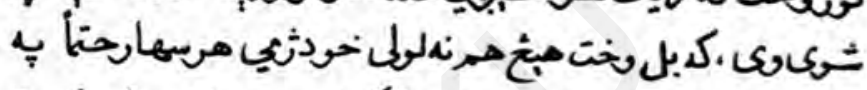

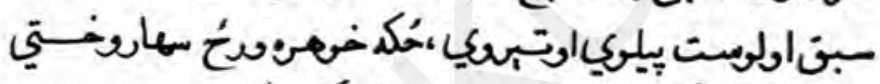

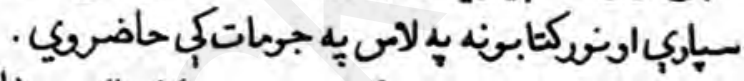

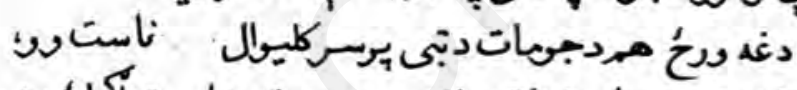

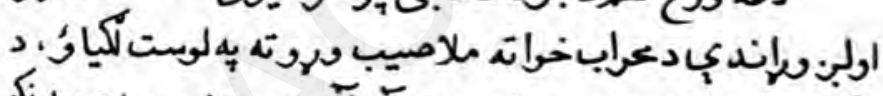

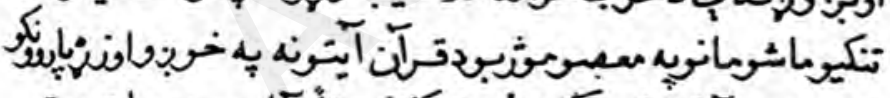

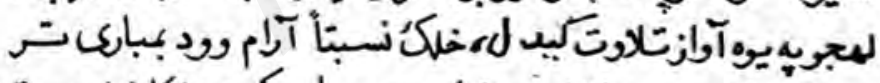

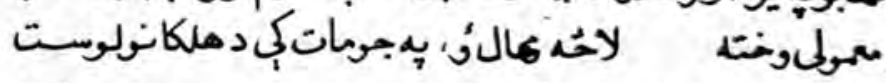

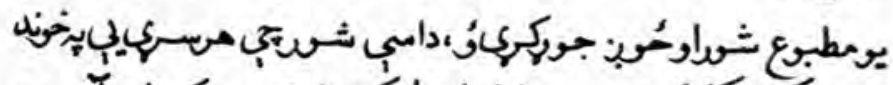

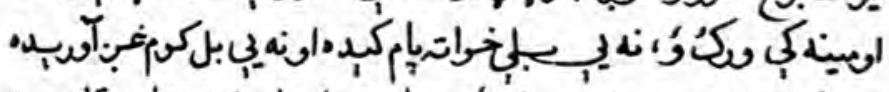

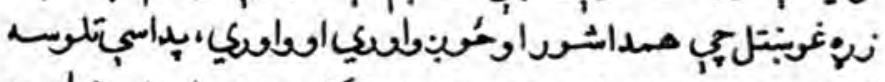

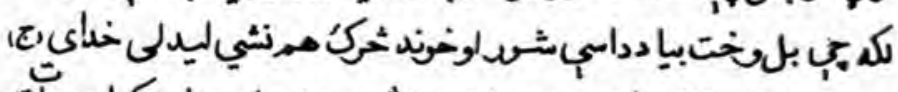

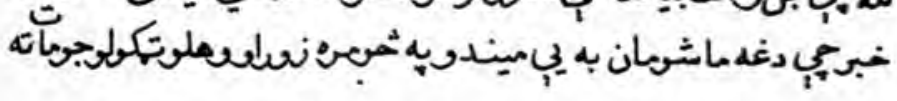




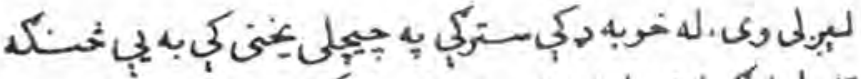

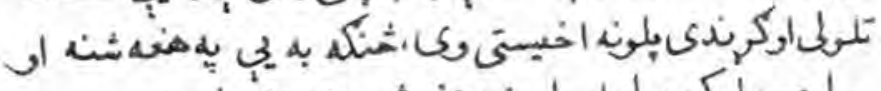

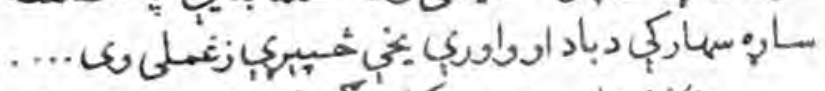

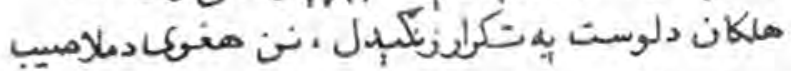

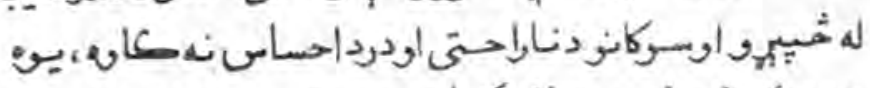

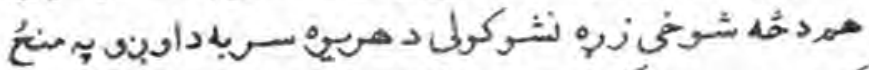

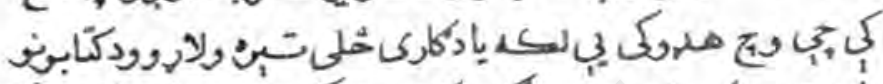

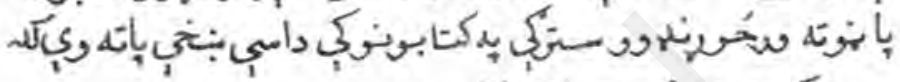

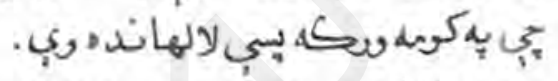

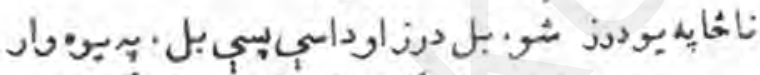

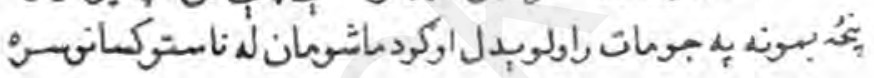

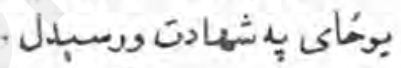

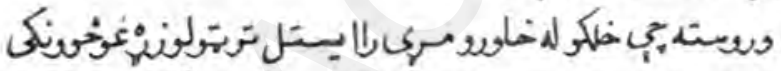

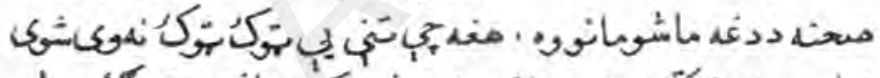

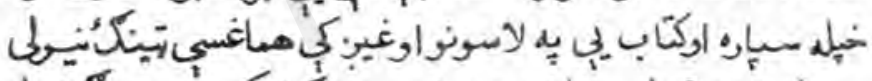

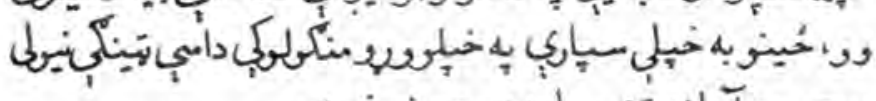

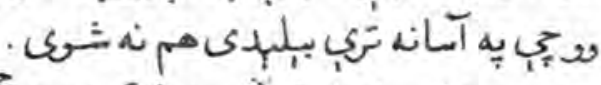

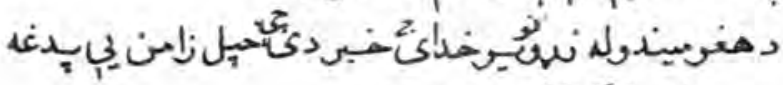

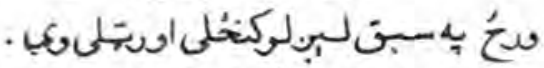

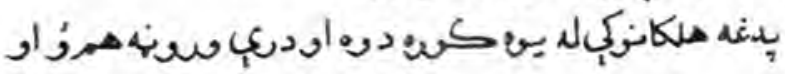

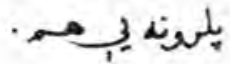




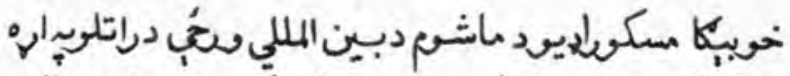

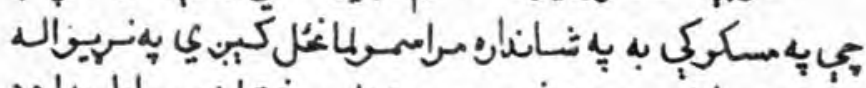

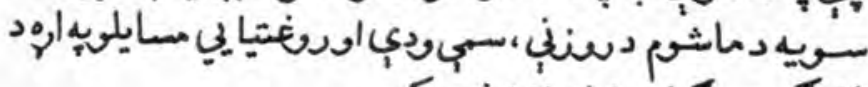

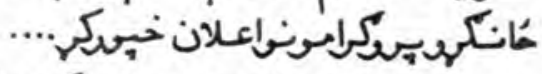

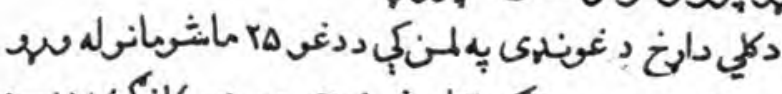

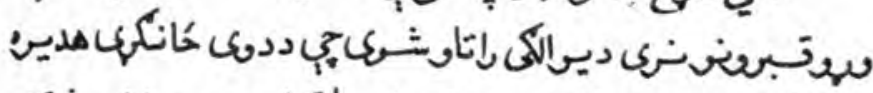

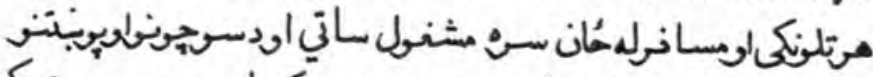

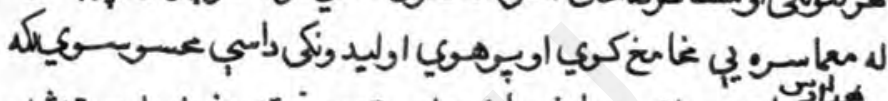

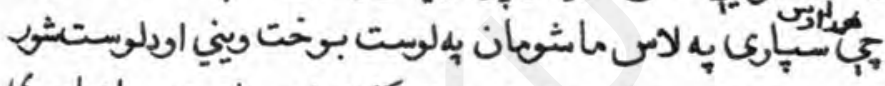

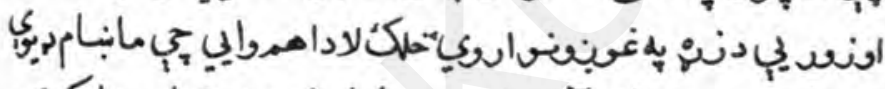

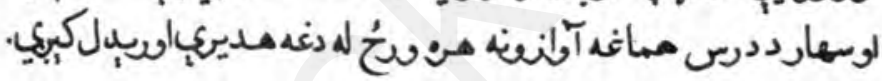




$$
\text { o }
$$




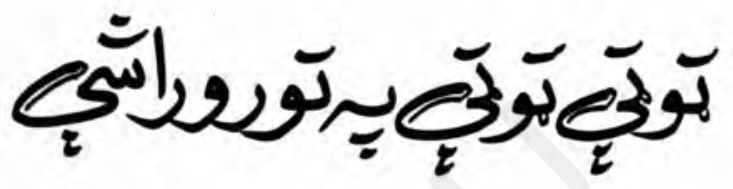

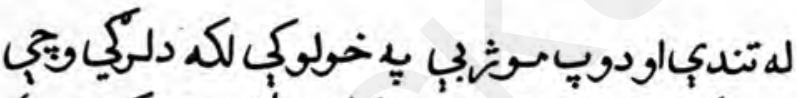

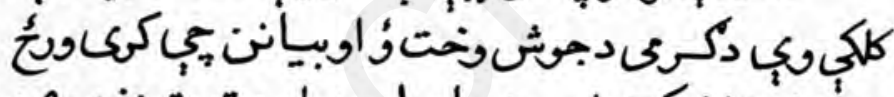

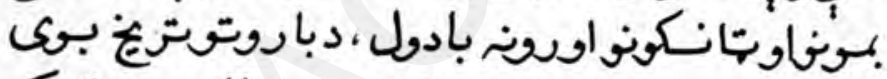

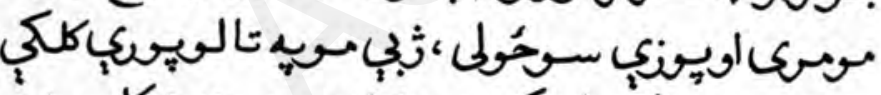

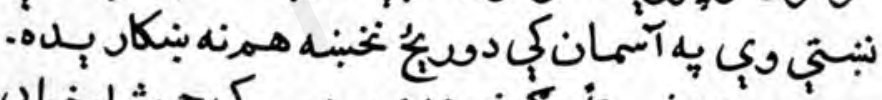

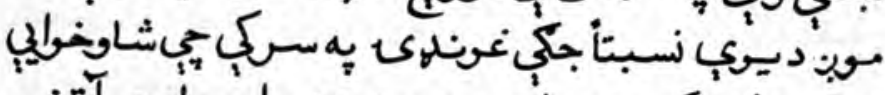

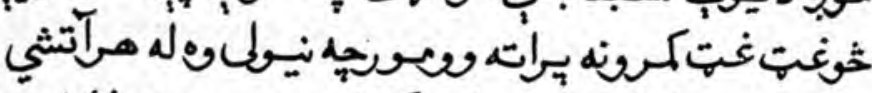

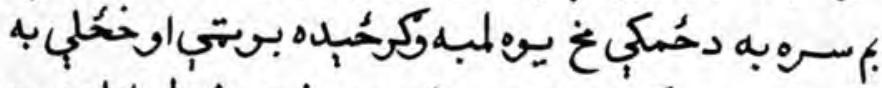

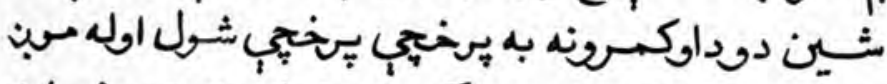

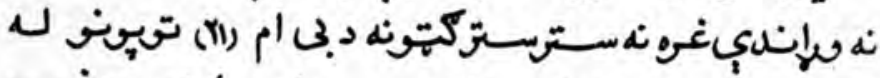

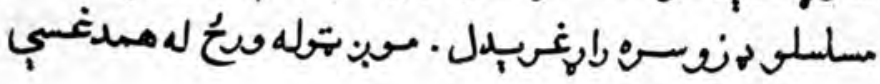




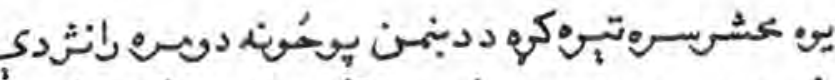
تش

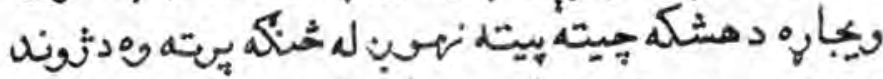

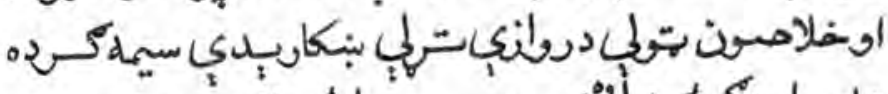

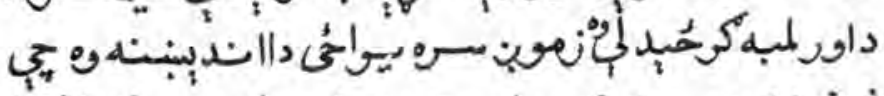

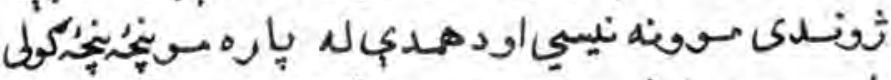

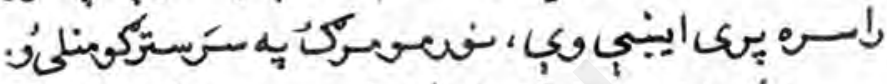

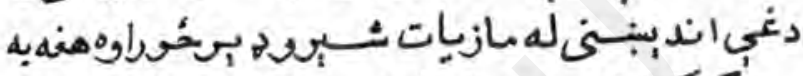

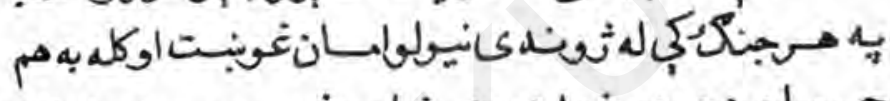

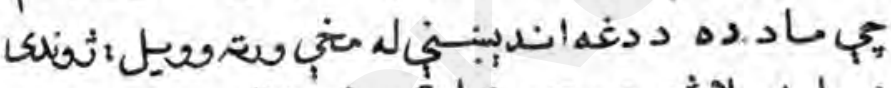

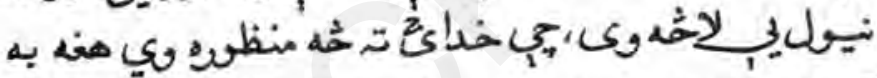

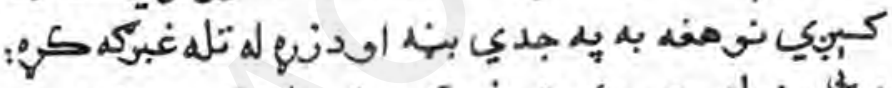

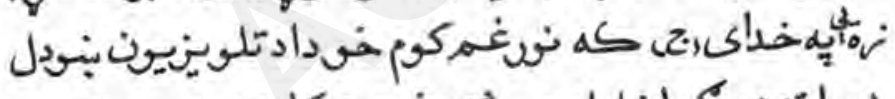

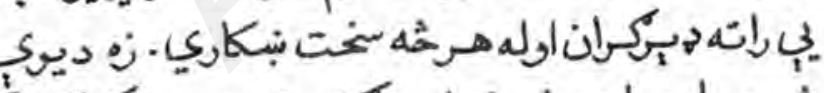

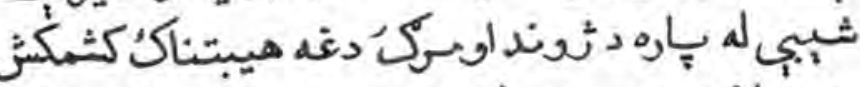

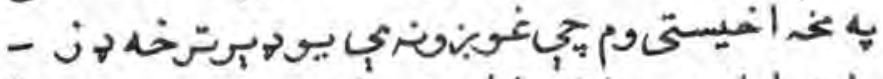

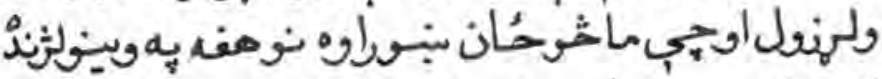

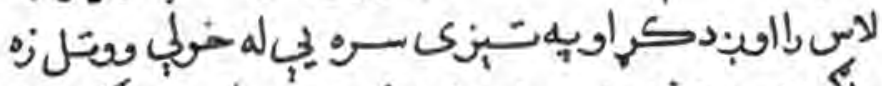

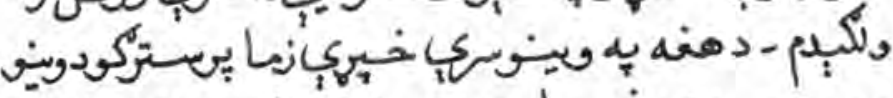

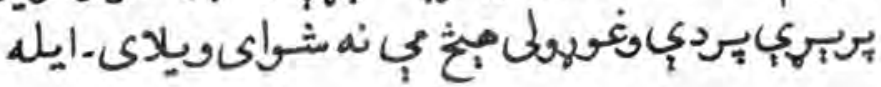




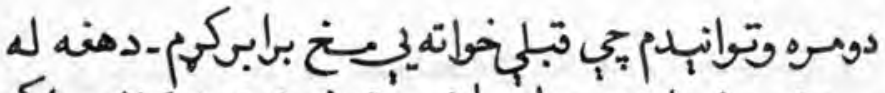

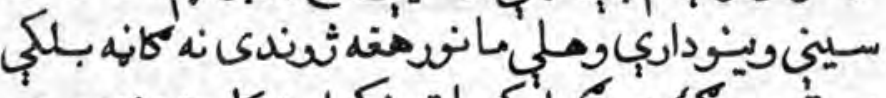

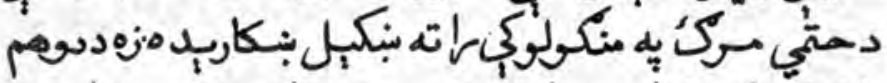

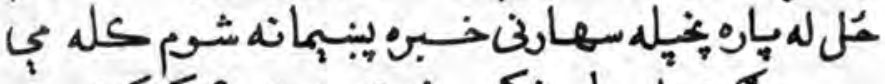

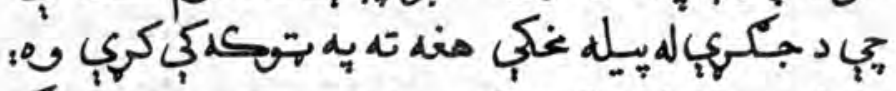

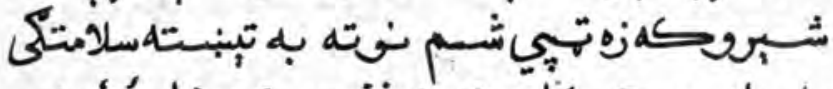

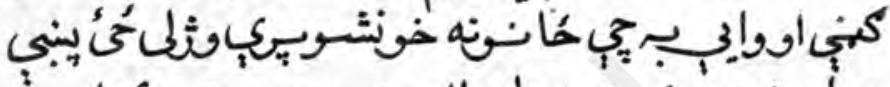

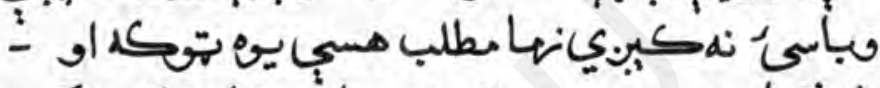

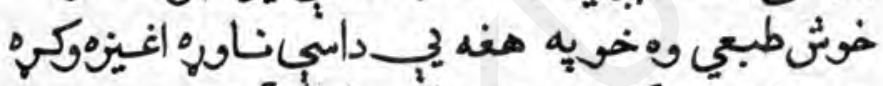

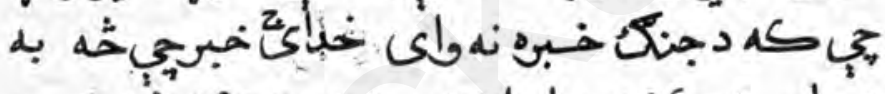

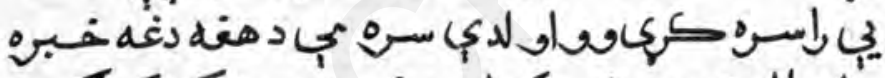

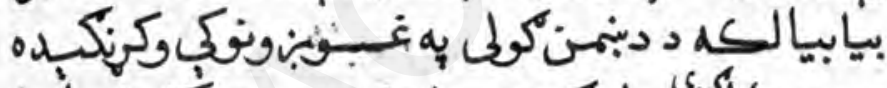

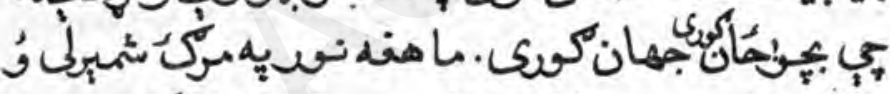

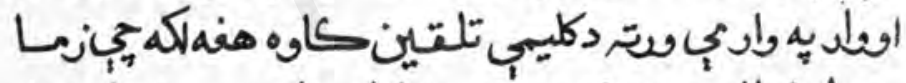

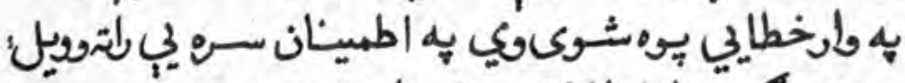

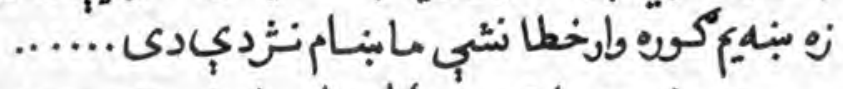

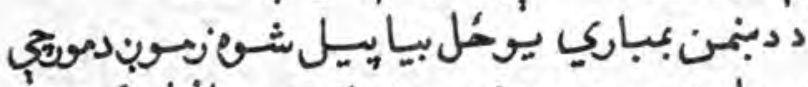

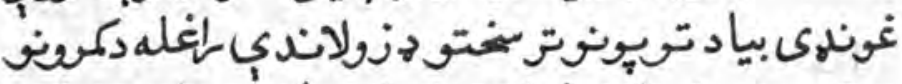

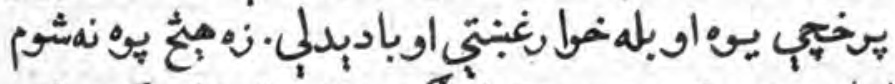

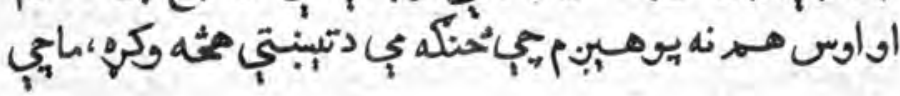




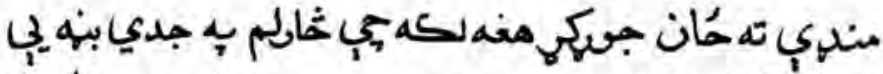

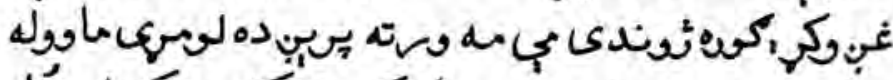

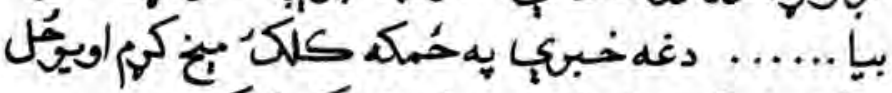

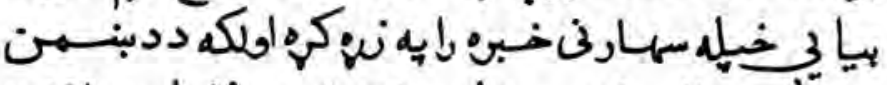

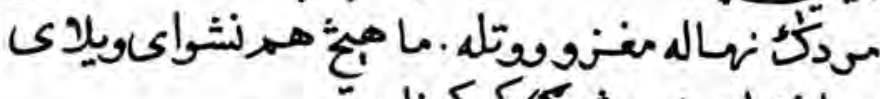

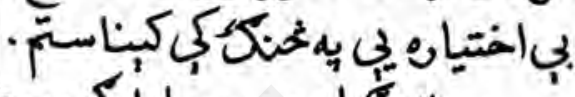

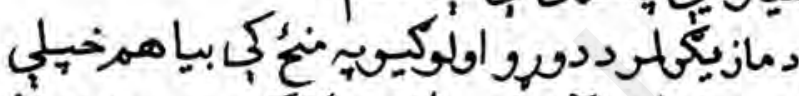

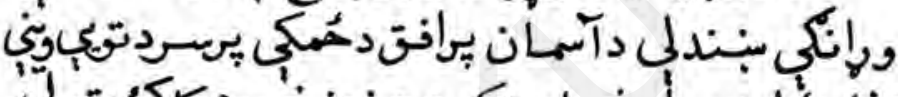

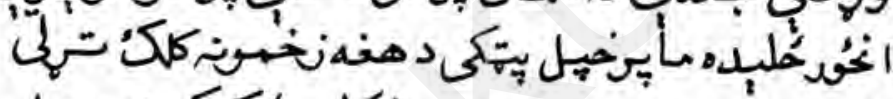
وُخويته

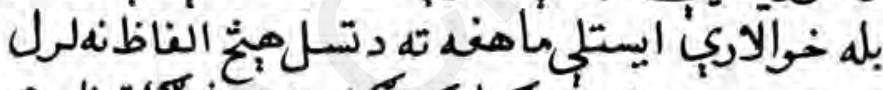

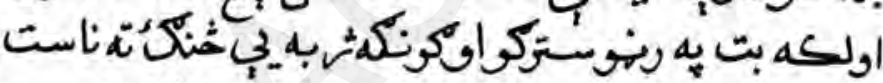

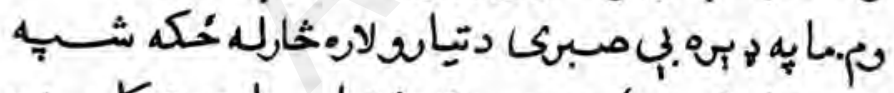

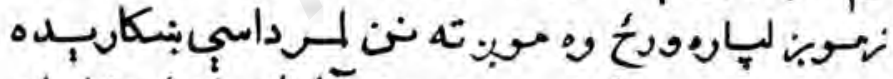

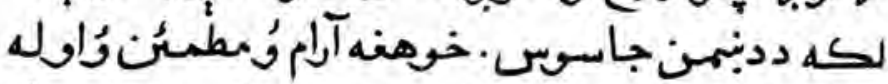

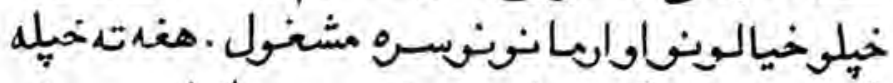

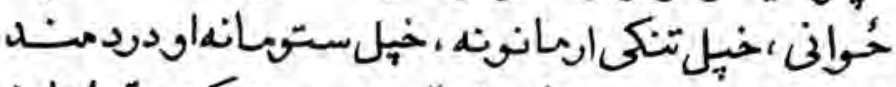

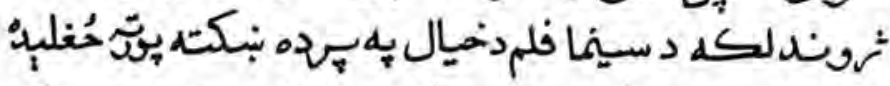

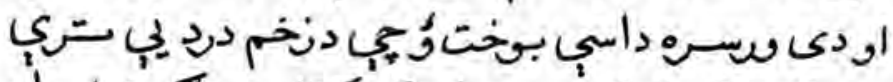

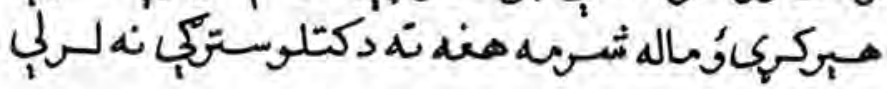




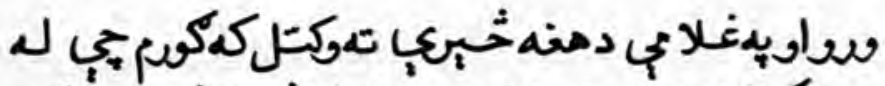

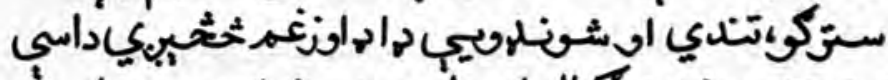

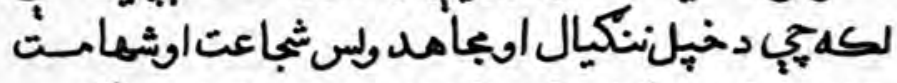

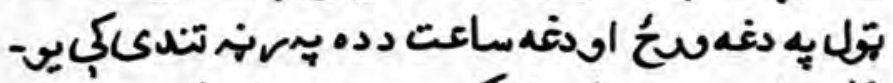

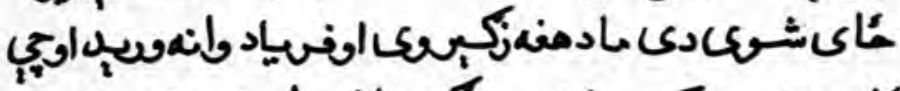

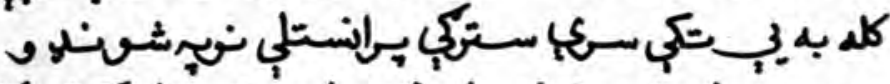

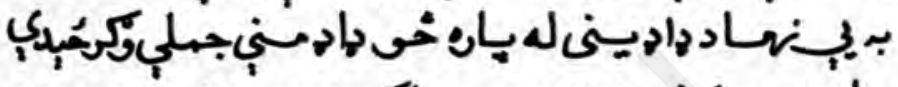

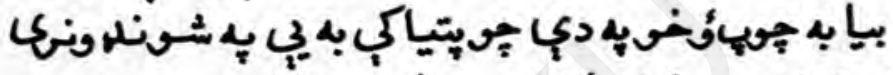

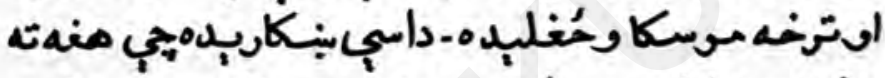

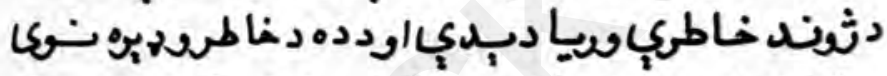

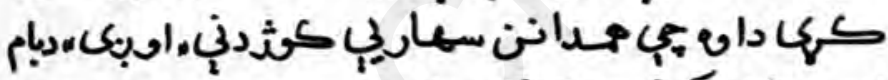

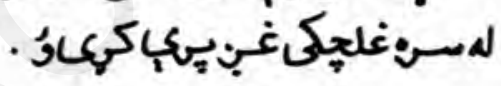

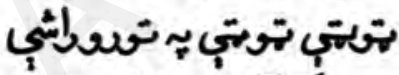

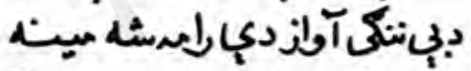

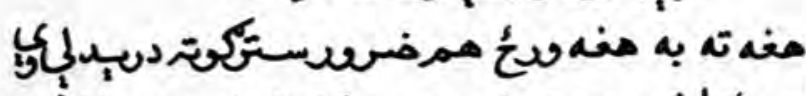

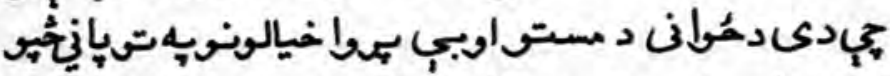

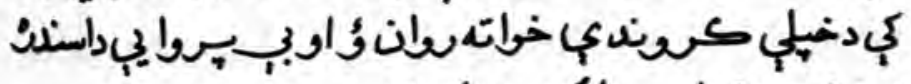

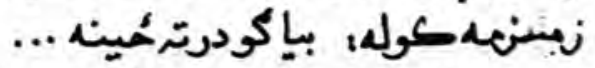

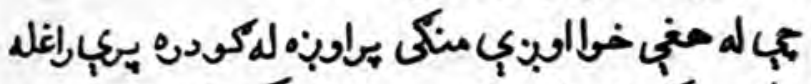

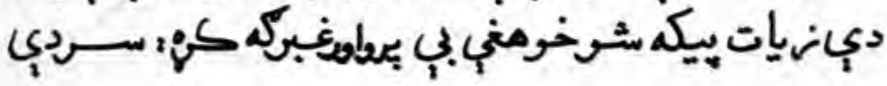




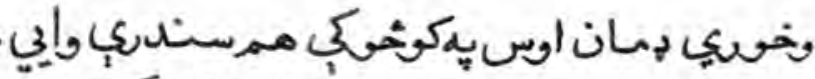

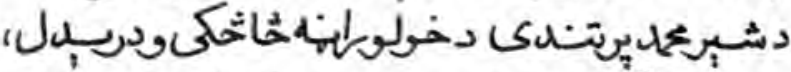

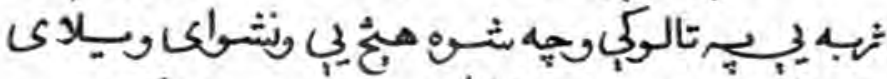

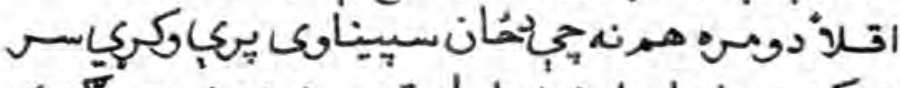

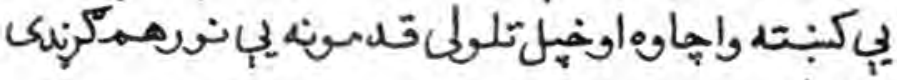

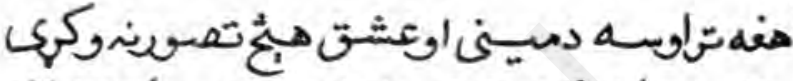

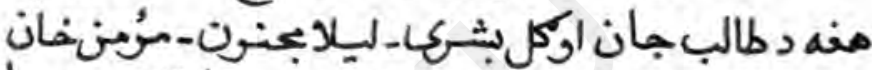

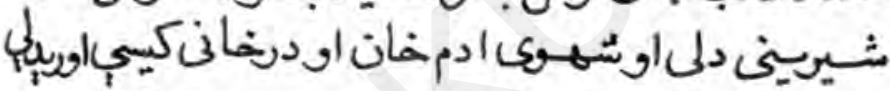

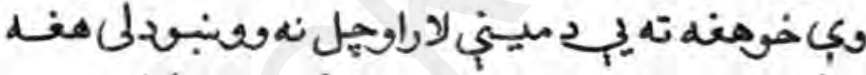

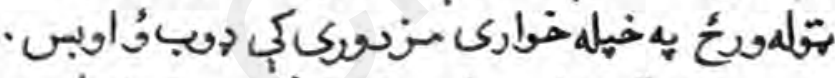

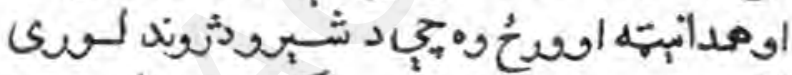

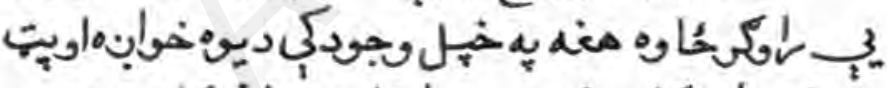

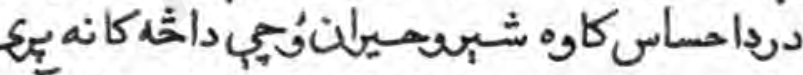

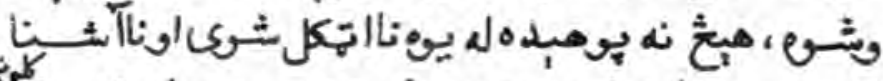

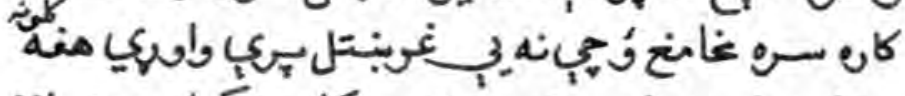

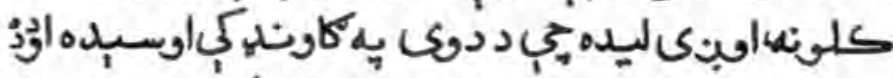

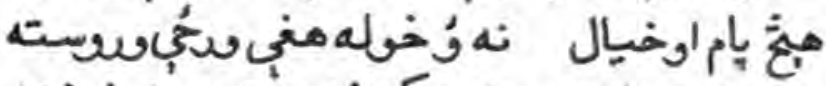

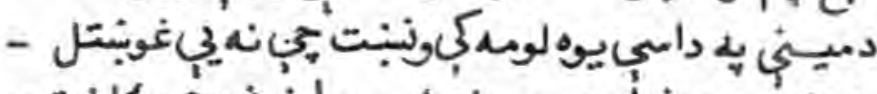

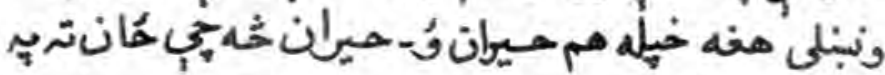




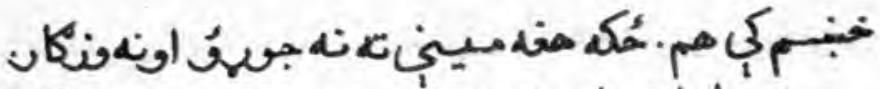

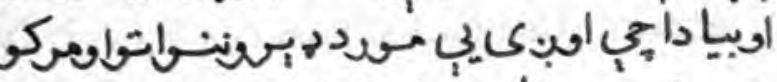

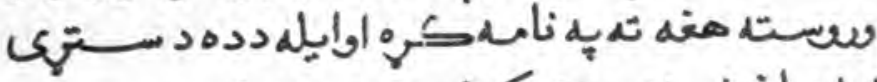

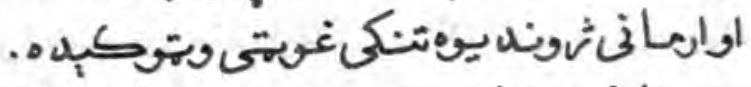

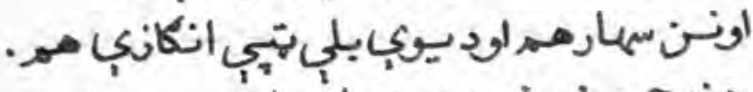

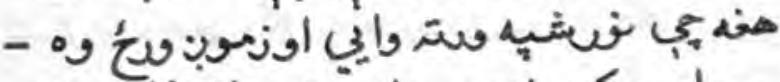

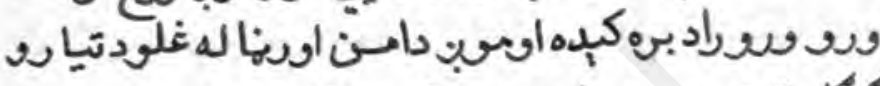

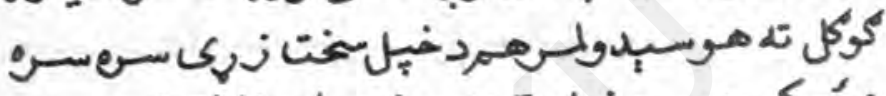

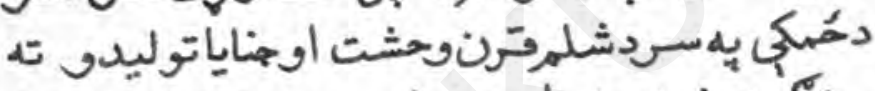

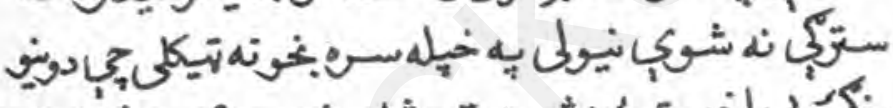

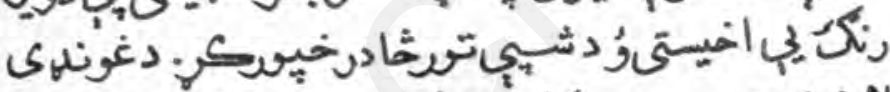

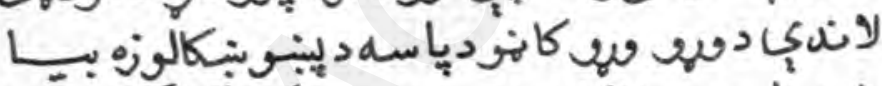

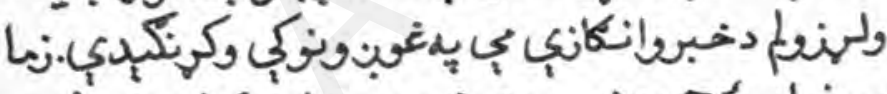

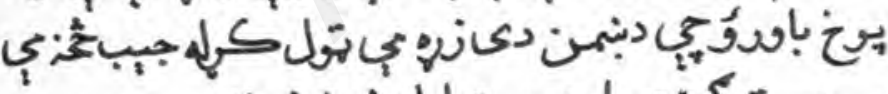

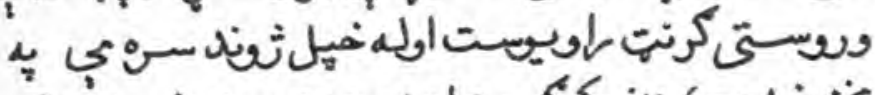

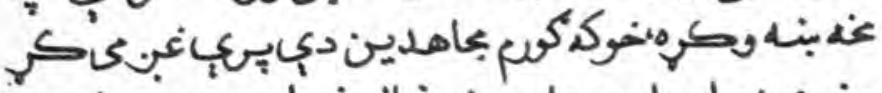

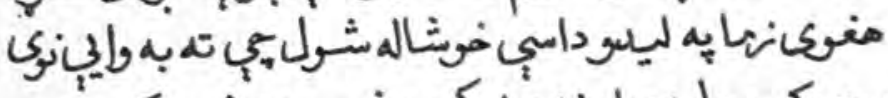

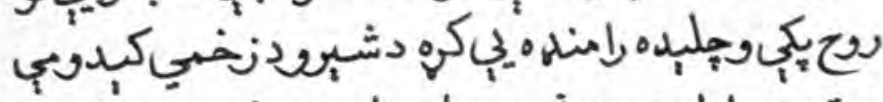

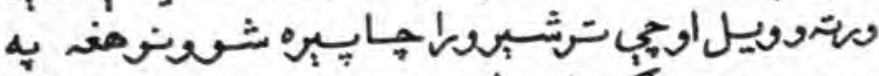

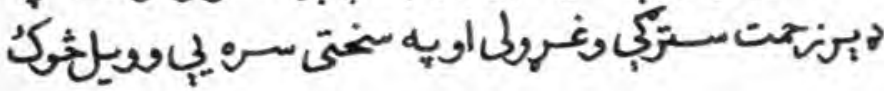




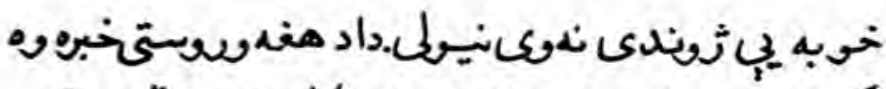

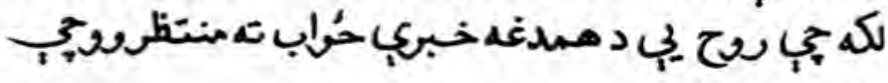

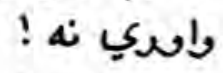

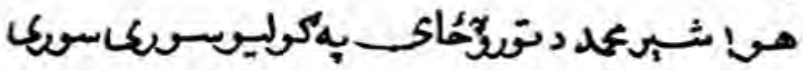

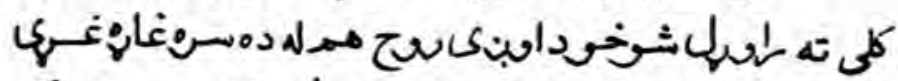

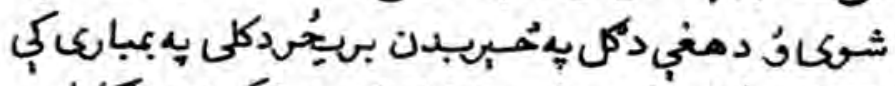

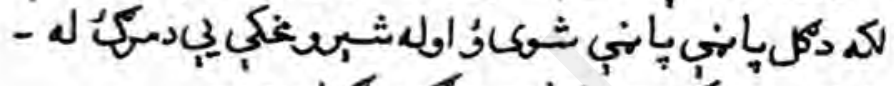

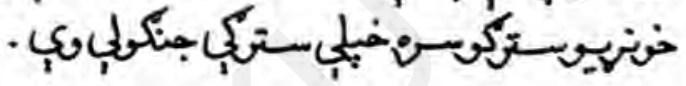




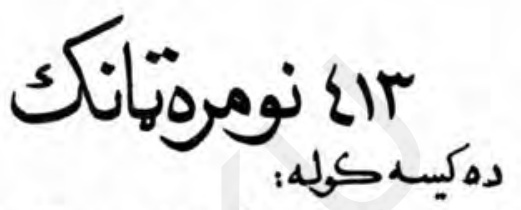

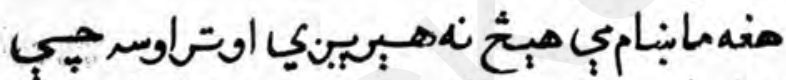

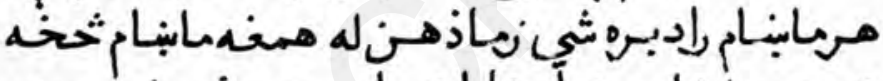

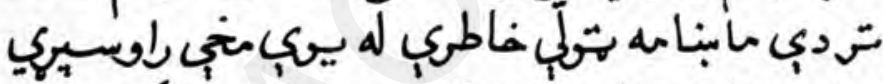

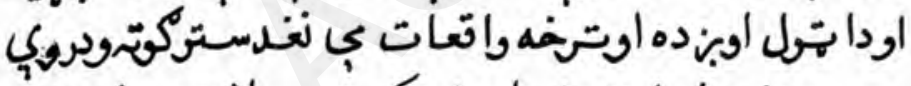

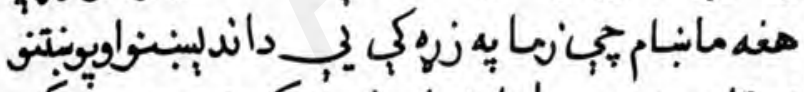

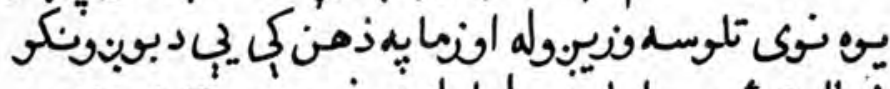

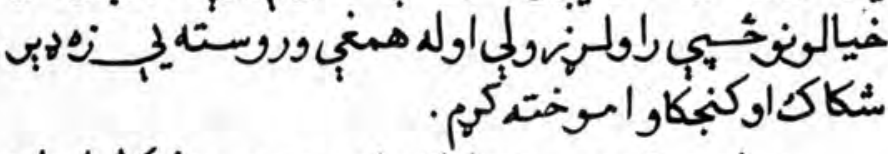

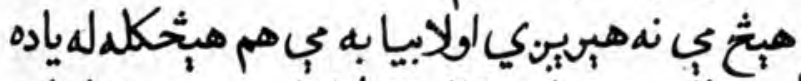

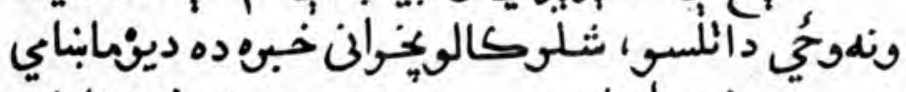

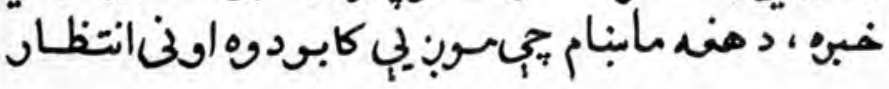




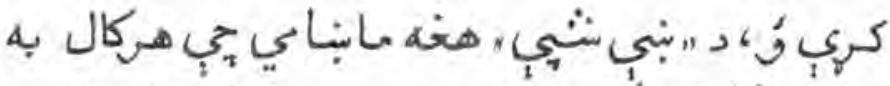

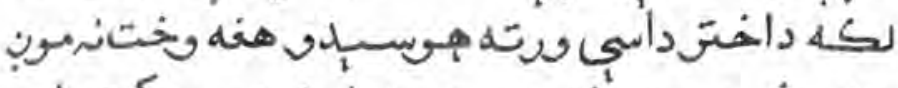

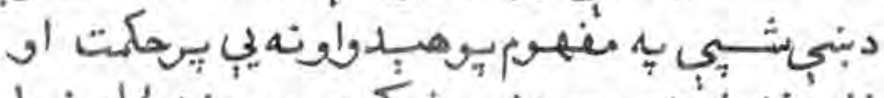

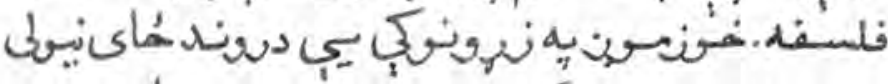

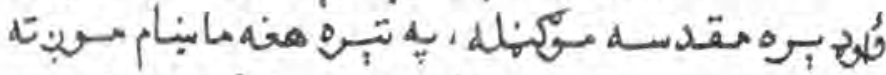

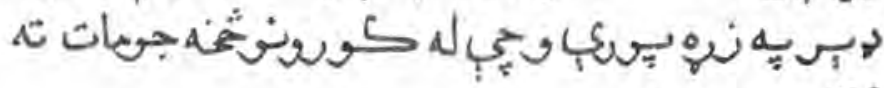

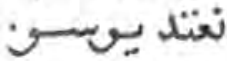

خوت ك إن

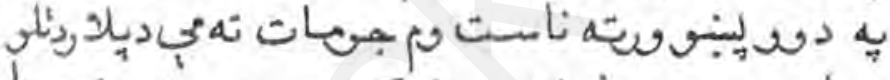

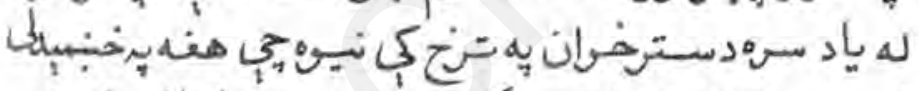

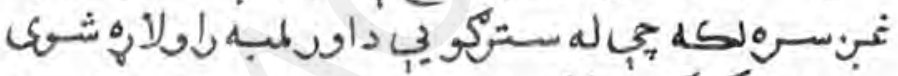

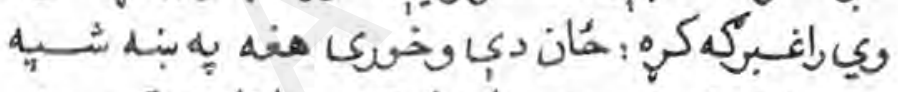

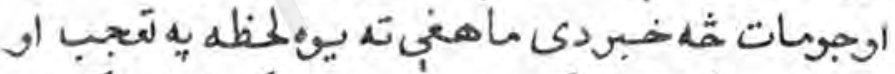

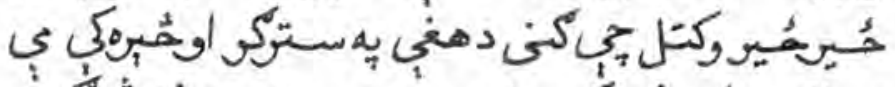

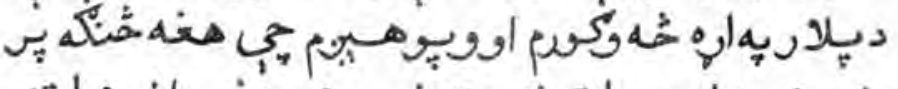

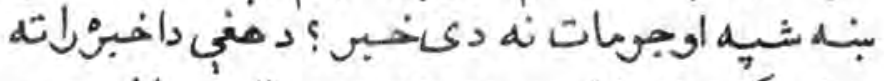

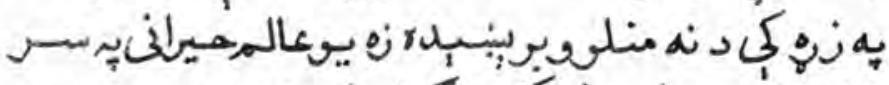

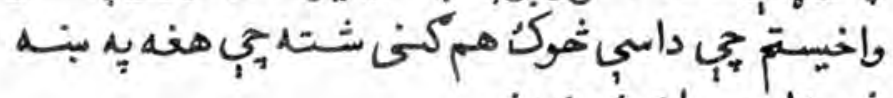

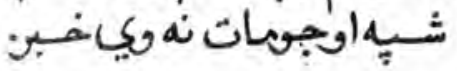




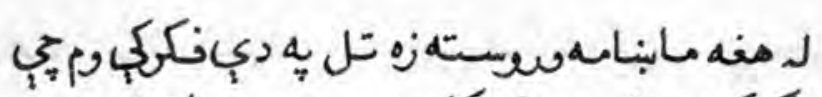

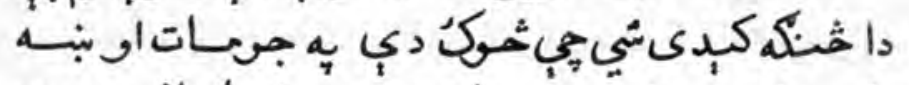

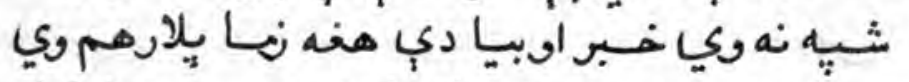

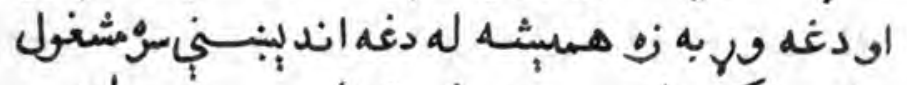

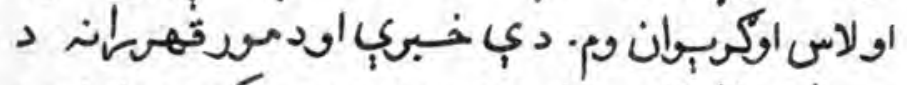

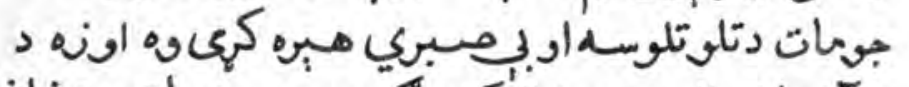

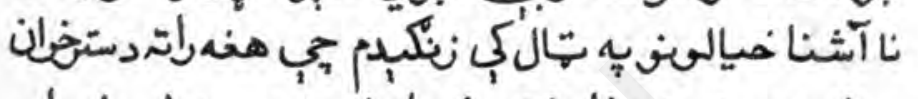

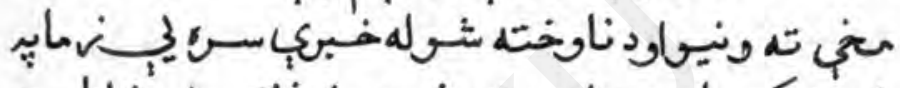

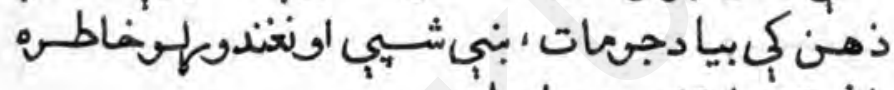

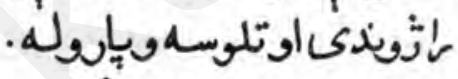

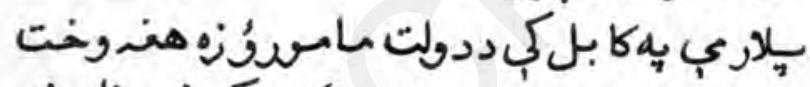

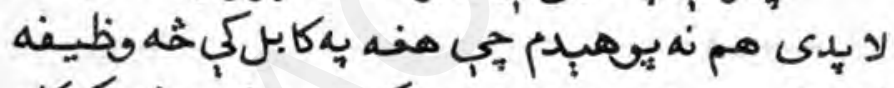

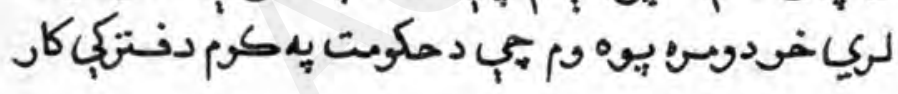
كري.

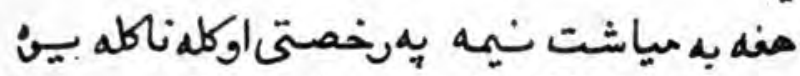

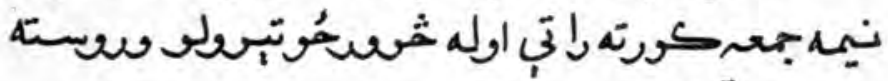

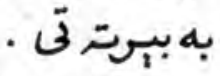

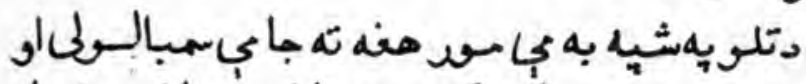

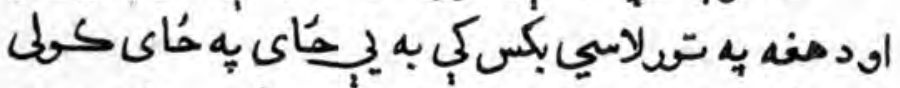

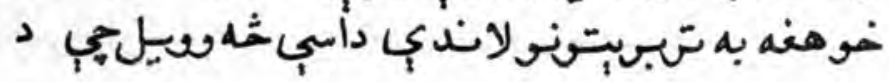

IIr 


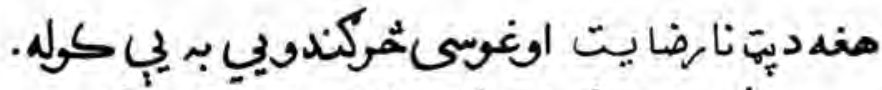

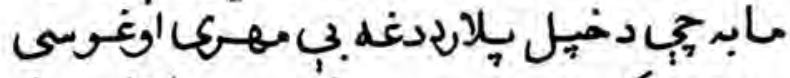

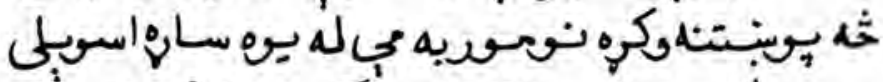

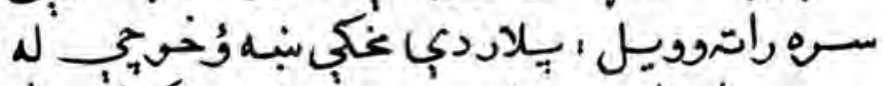

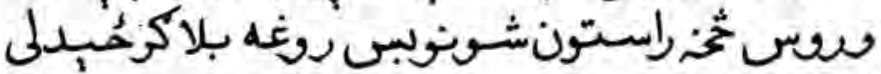

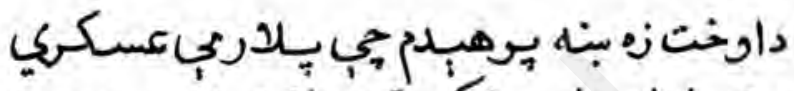

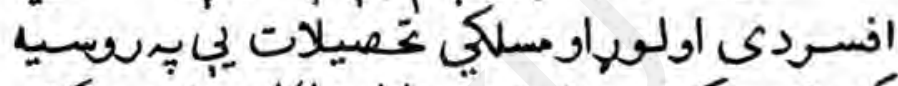

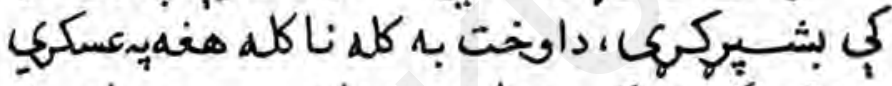

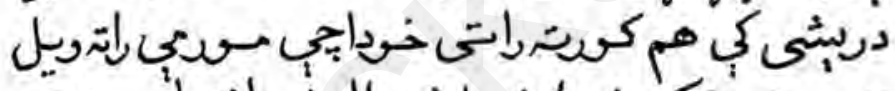

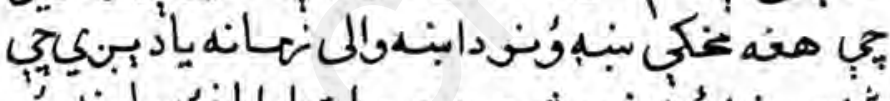

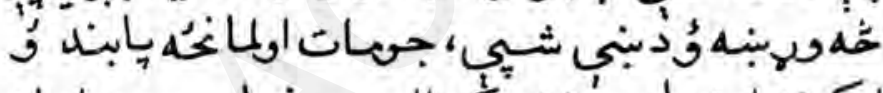

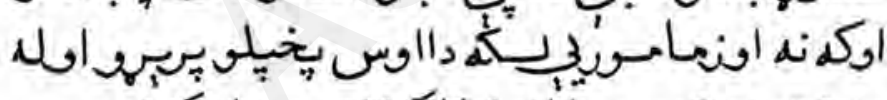

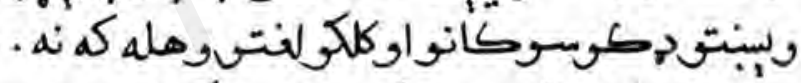

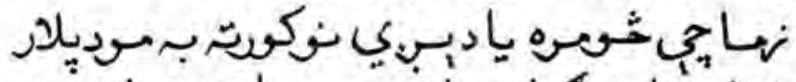

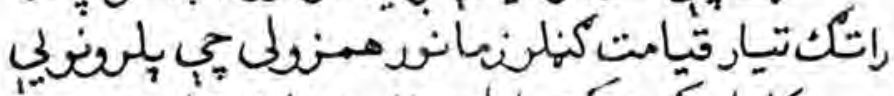

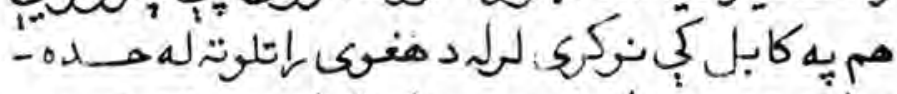

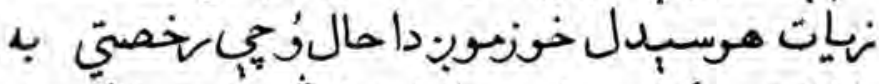

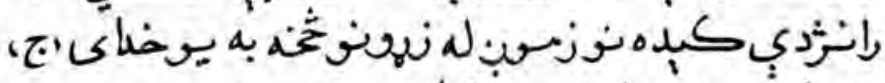

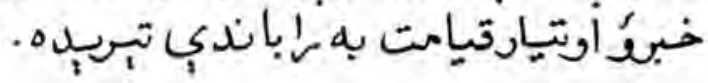




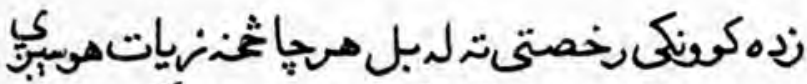

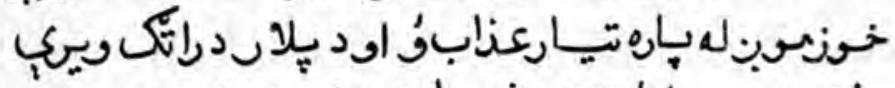

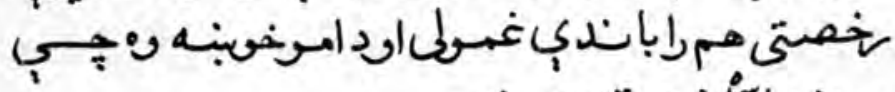

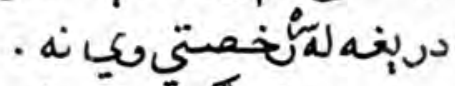

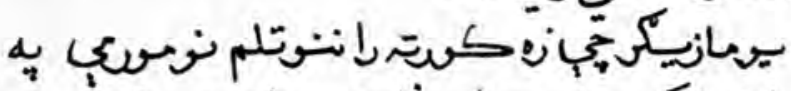

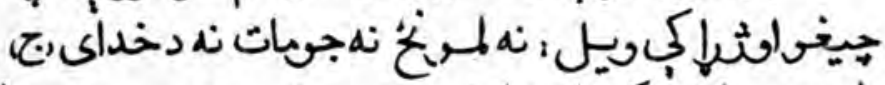

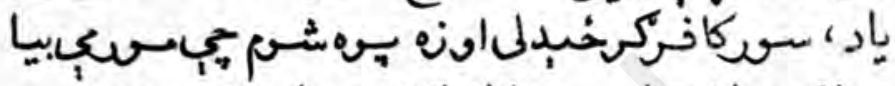

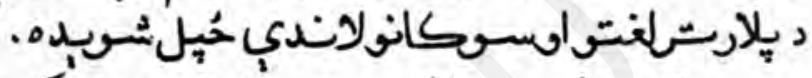

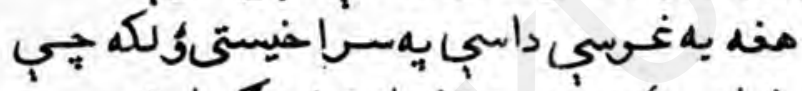

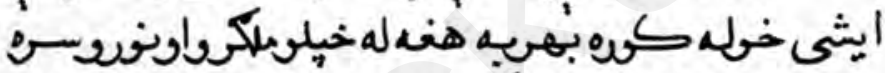

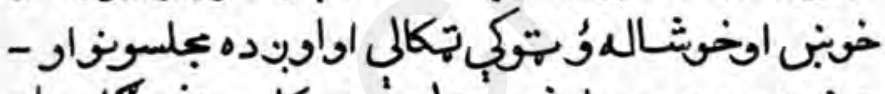

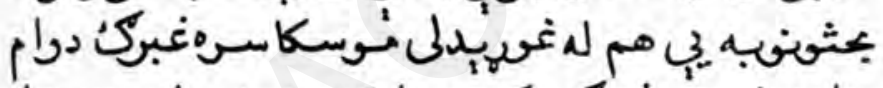

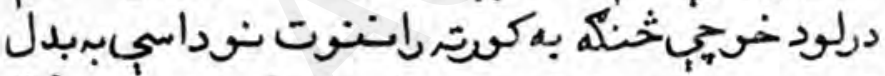

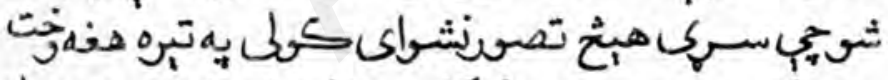

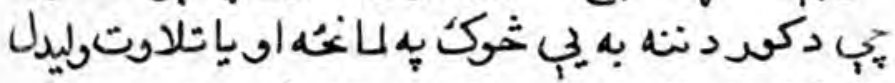

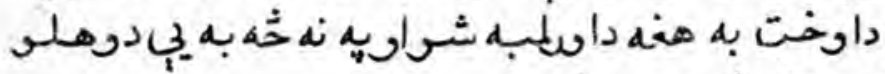

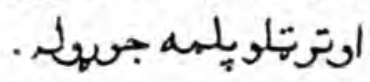

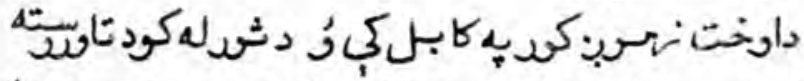

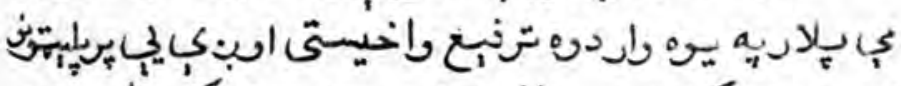

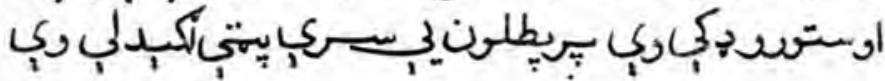




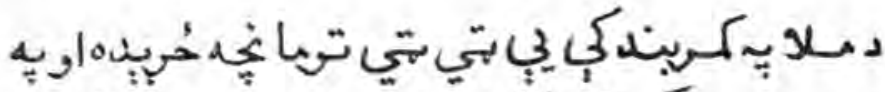

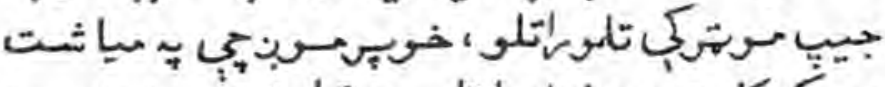

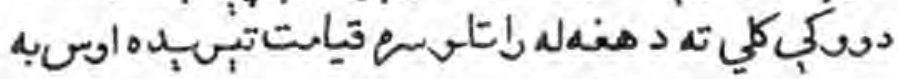

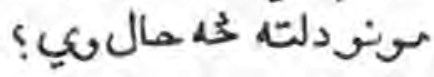

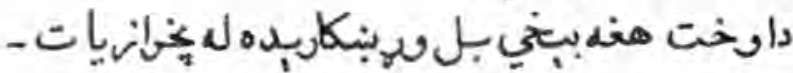

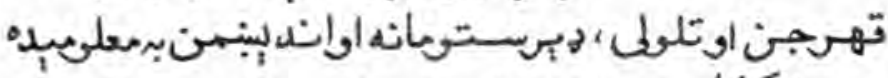

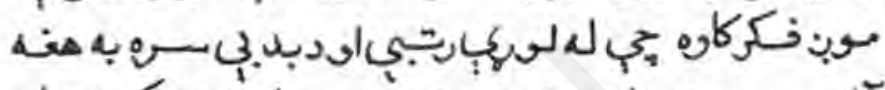

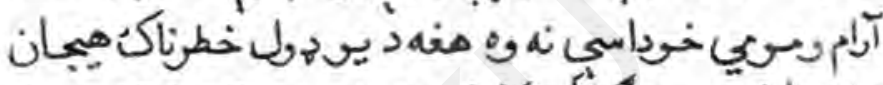

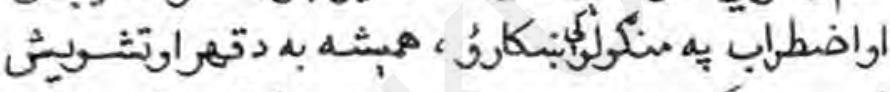

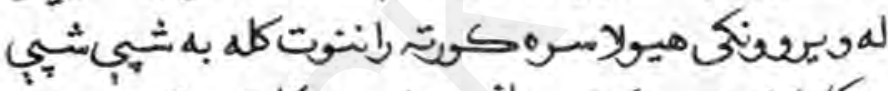

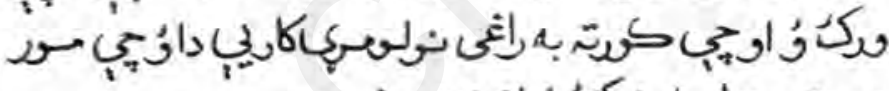

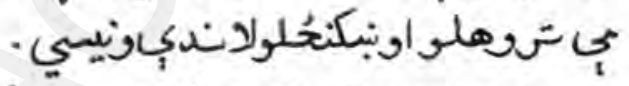

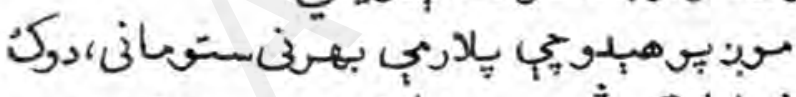

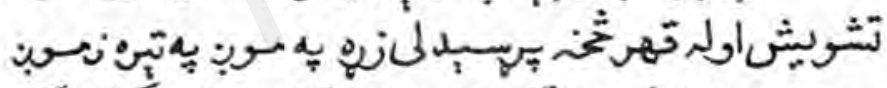

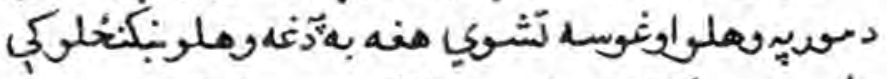

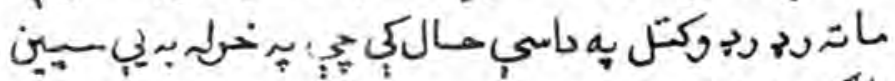

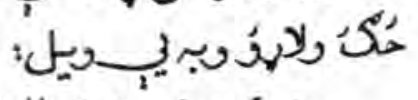

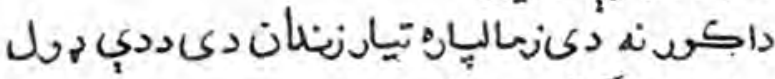

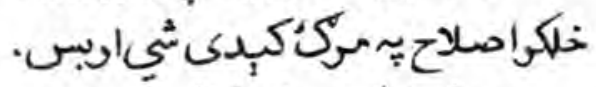

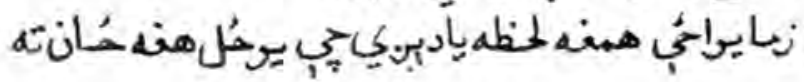




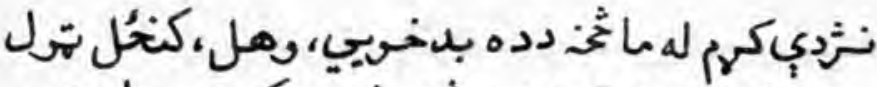

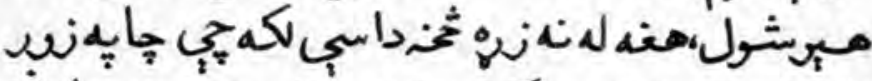

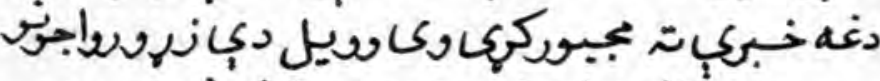

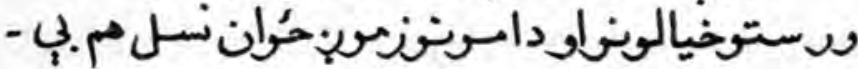

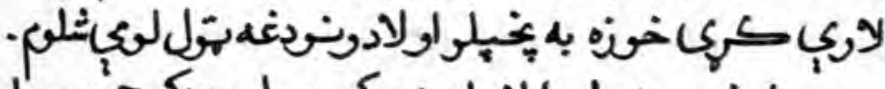

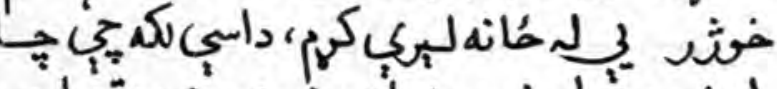

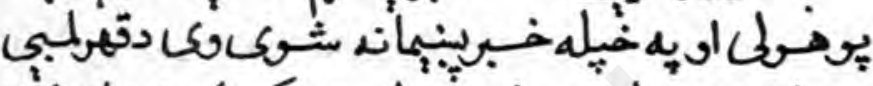

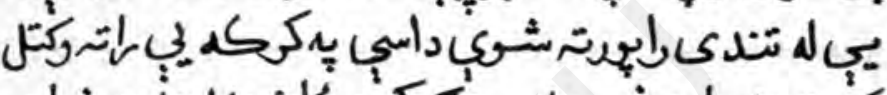

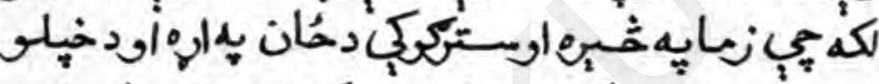

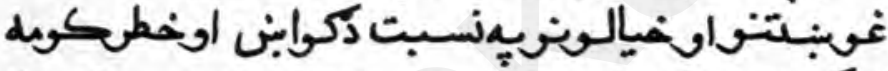

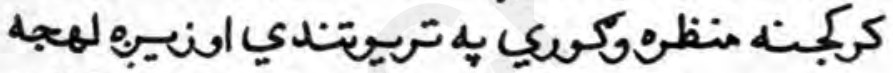

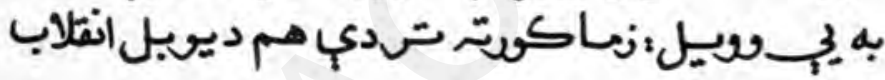

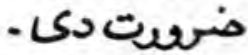

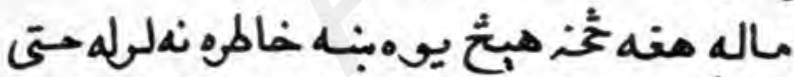

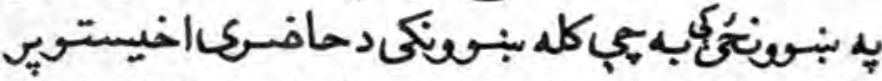

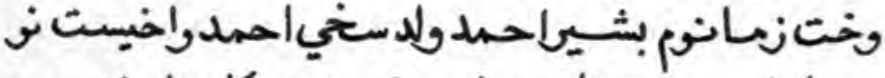

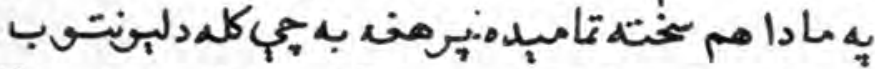

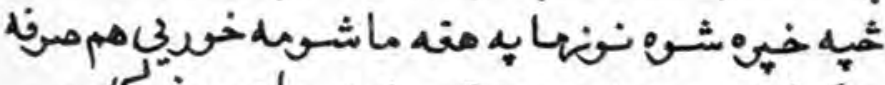

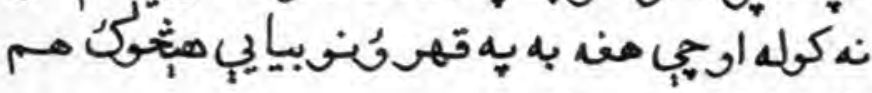
يخي تح نشوى دريدلى . 


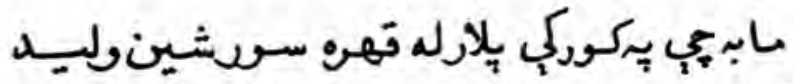

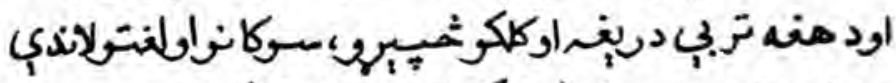

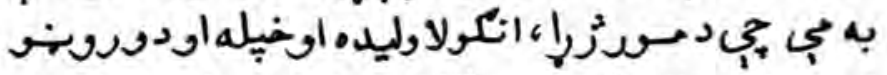

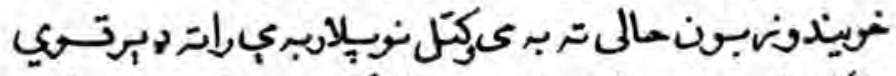

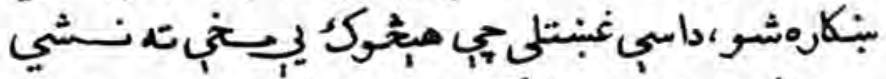

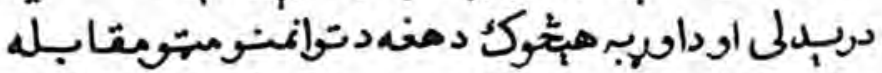

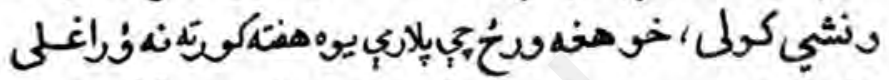

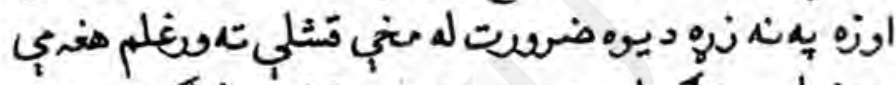

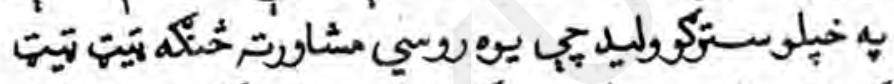

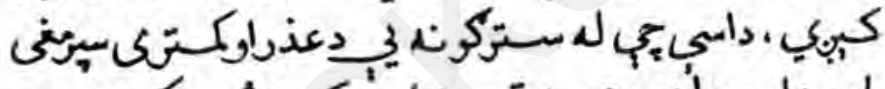

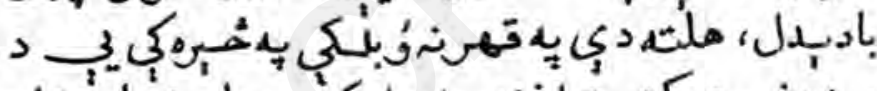

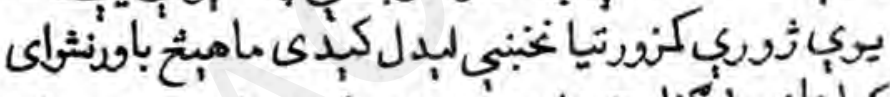

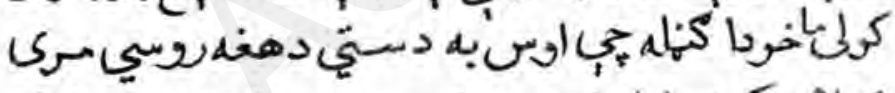

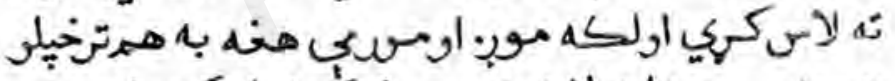

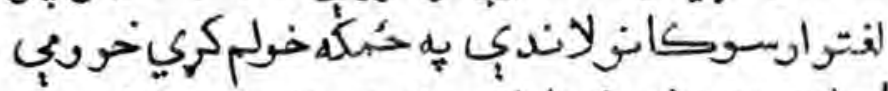

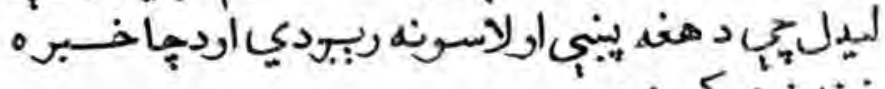

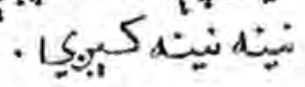

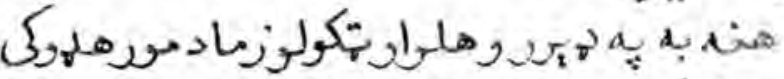

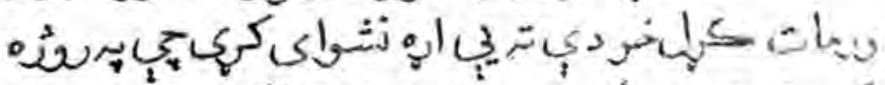

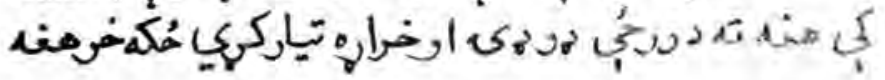




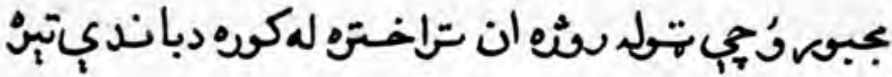
كري

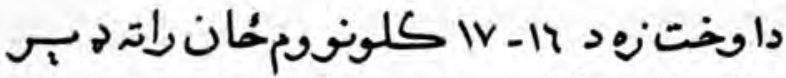

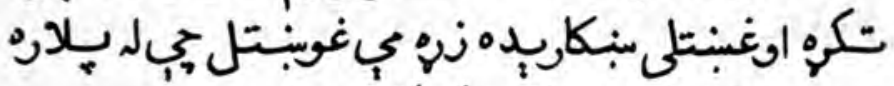

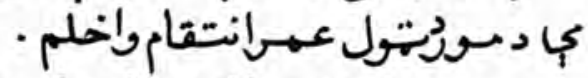

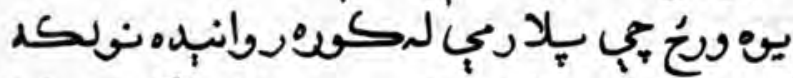

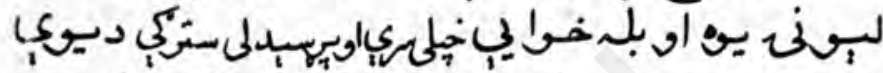

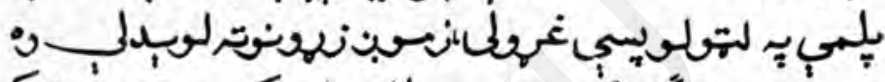

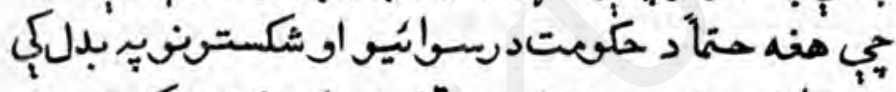

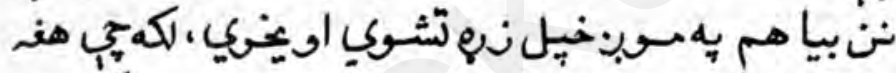

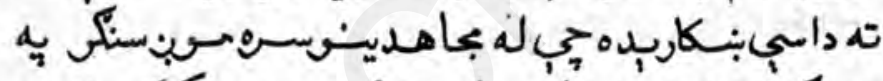

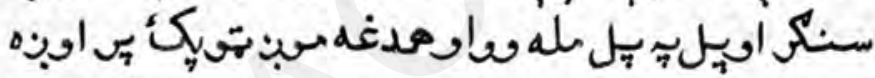

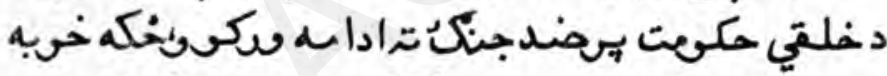

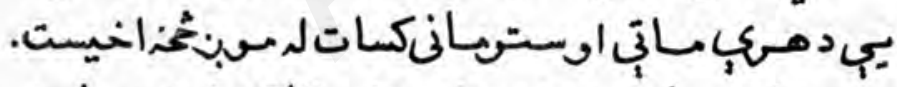

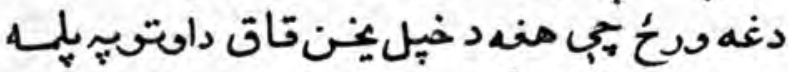

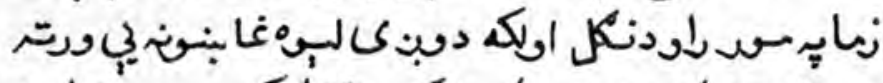

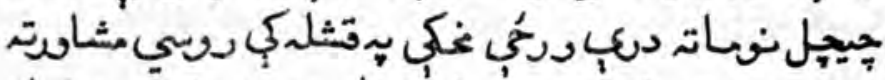

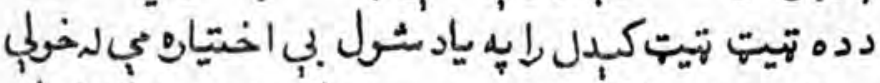

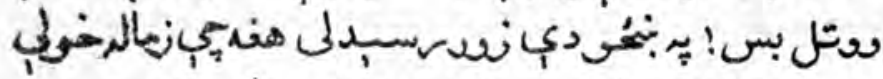

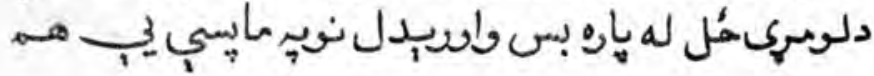




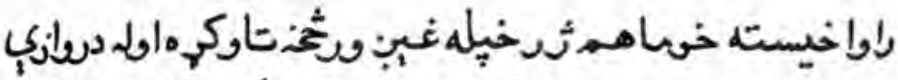

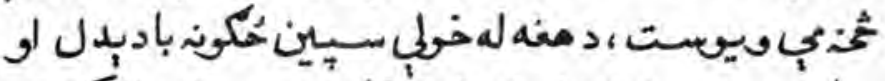

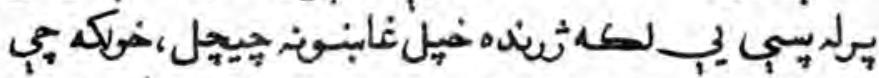

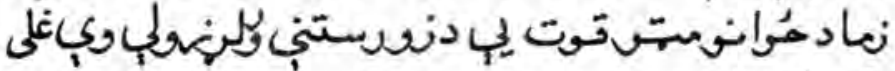

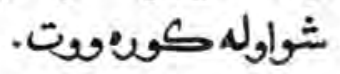

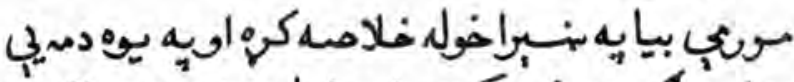

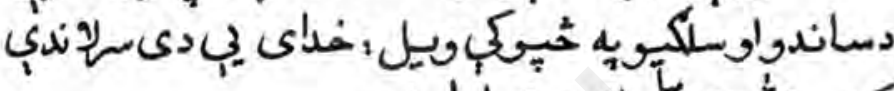

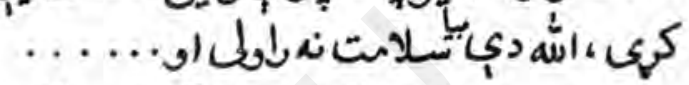

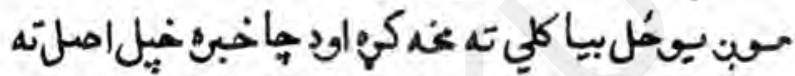

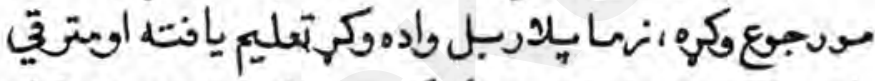

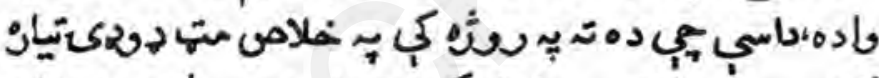

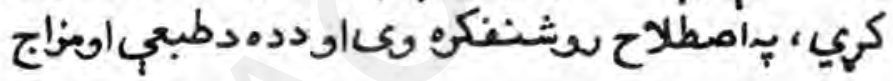
سروسمن

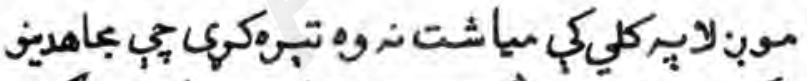

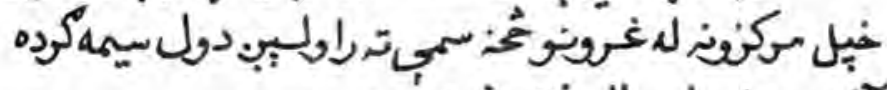

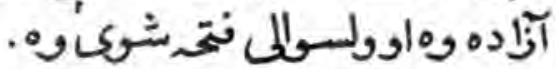

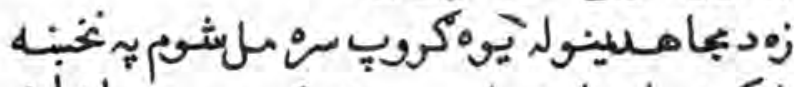

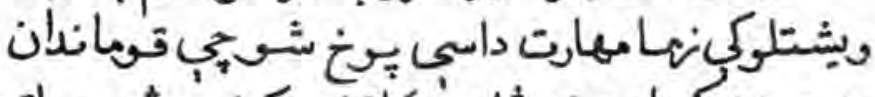

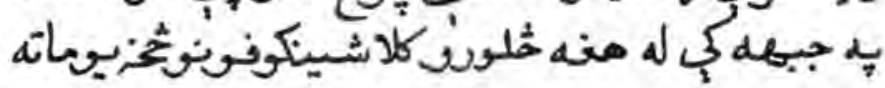
رأكن. 


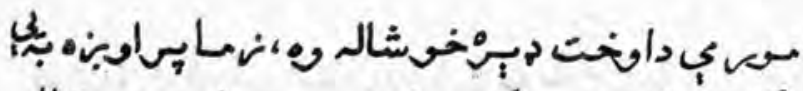

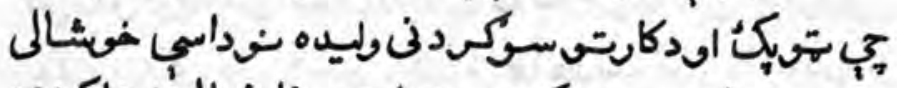

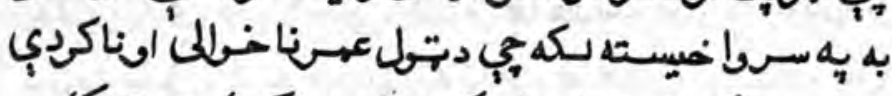

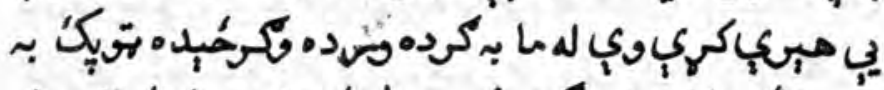

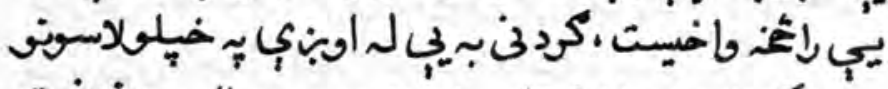

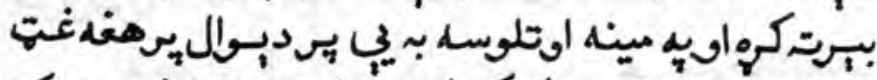

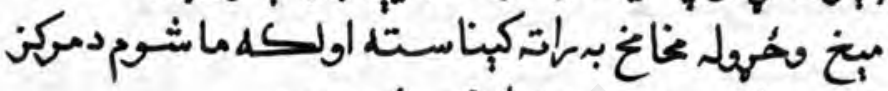

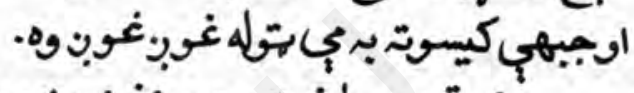

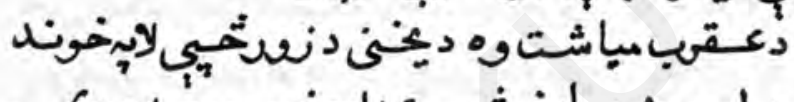

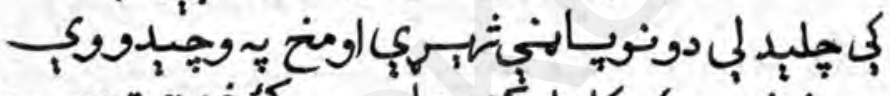

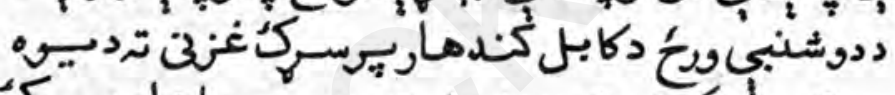

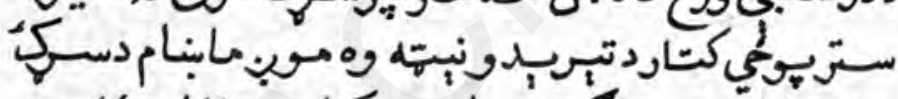

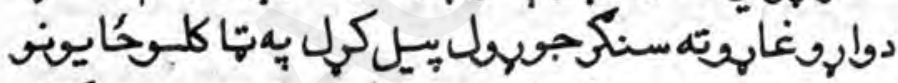

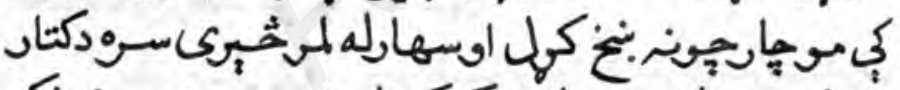

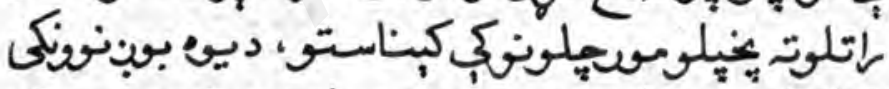

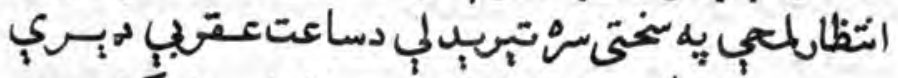

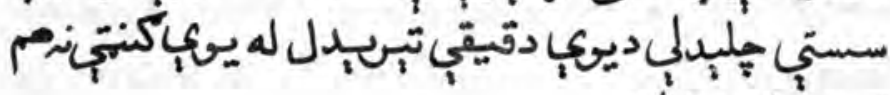

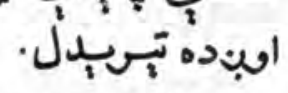

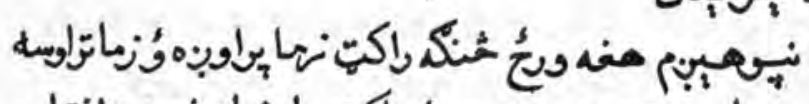

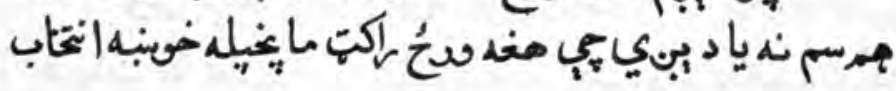




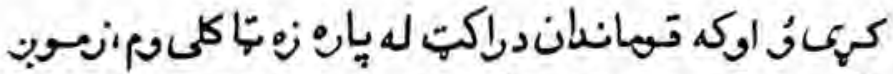

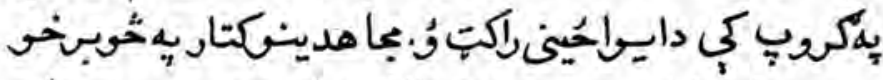

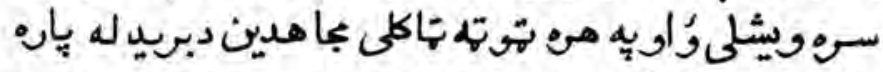

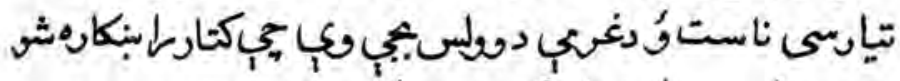

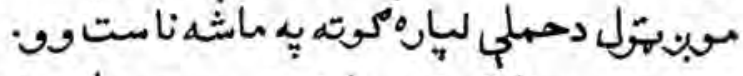

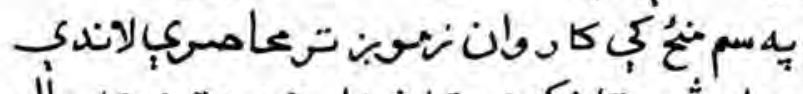

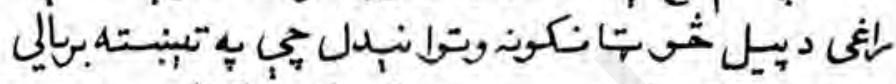

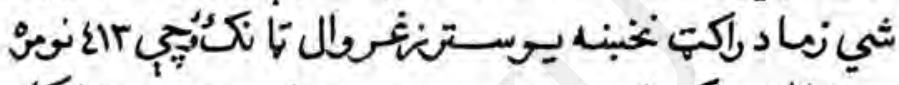

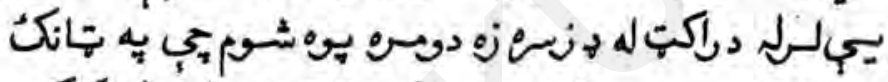

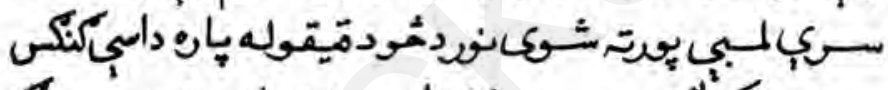

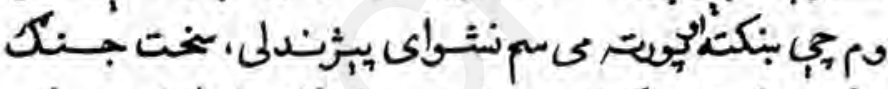

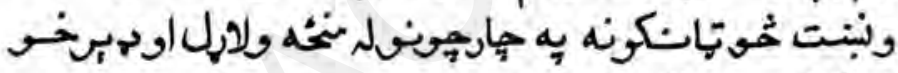

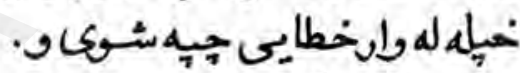

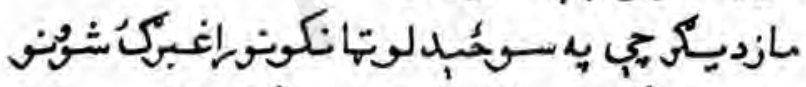

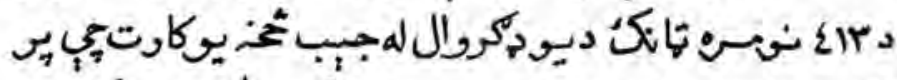

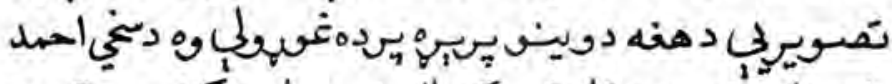

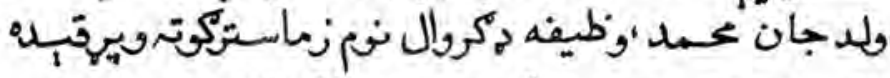

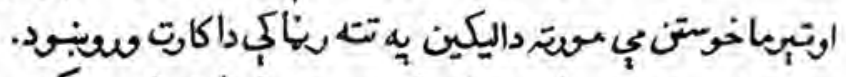

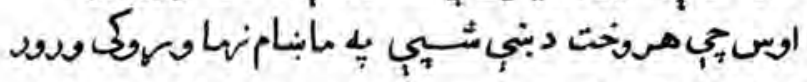

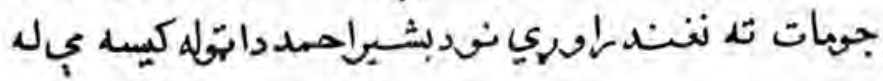




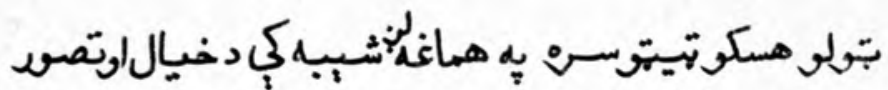

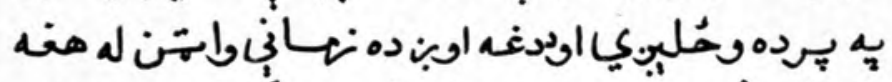

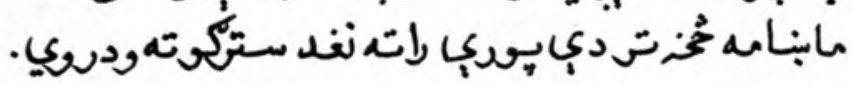

irr 
pe 


\section{دنئيالآثار}

حاب

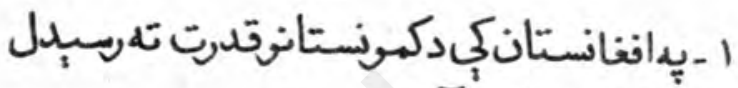

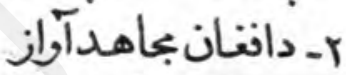

r- دافنانستان سياسياهزالب

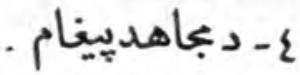

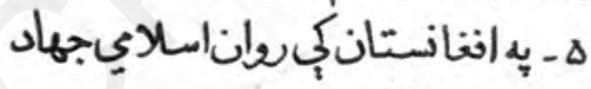

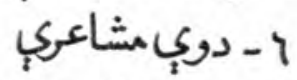

v - جرايدغيردولتئانغانستان

II

$$
\text { - } 1 \text { - خبري - جرايدي }
$$

"

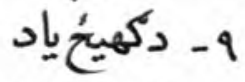

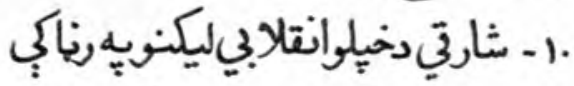

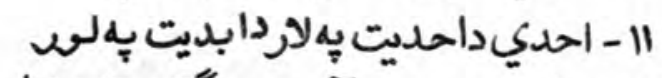

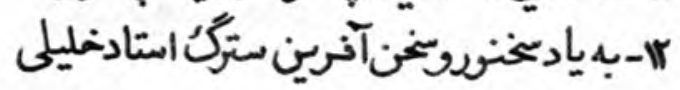

II

rا اسنادتاريخئانغانستان

"

$$
\text { عا- جهادي نتواكإن }
$$


جاي

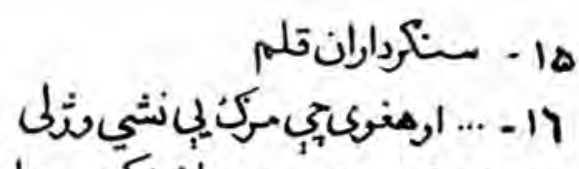

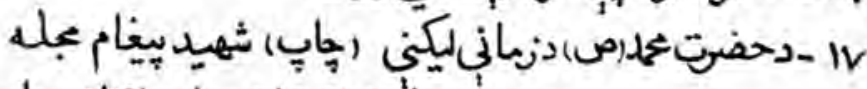

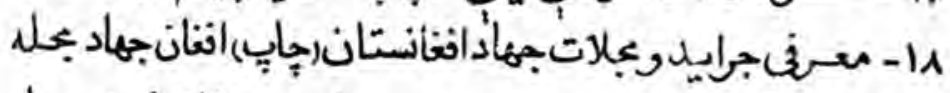

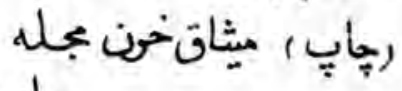

$$
\text { جائ }
$$

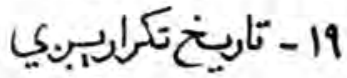$$
\text { r-r-مزلونيارينزلونه }
$$

ترجإِلاندي

جإِتهـيار

$$
\text { , }
$$

",

"

"

"

"r

\%

"

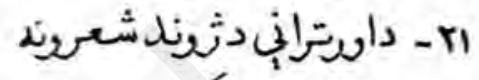

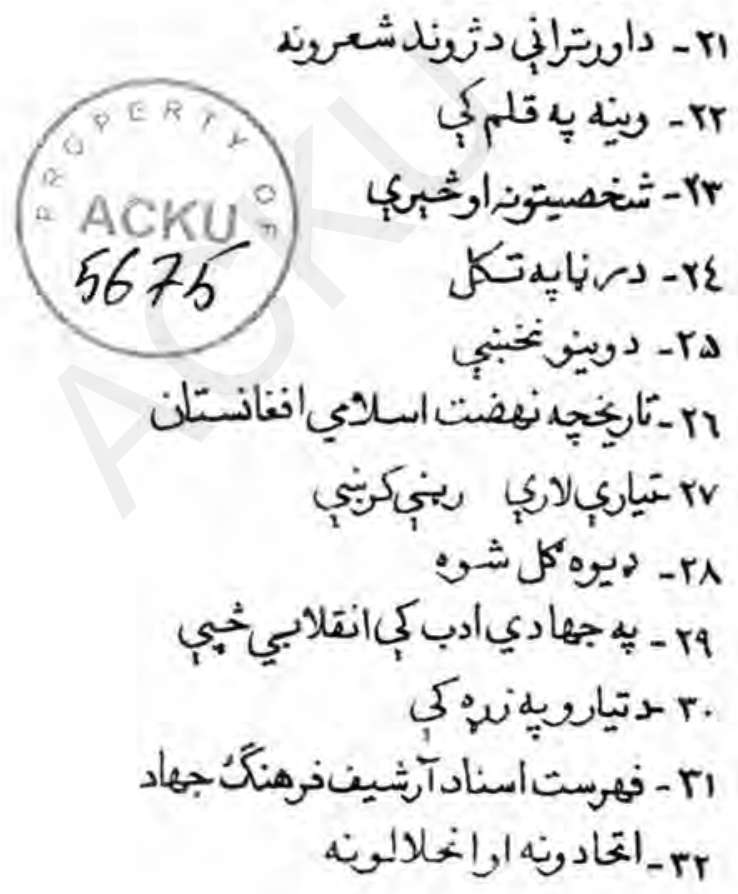

